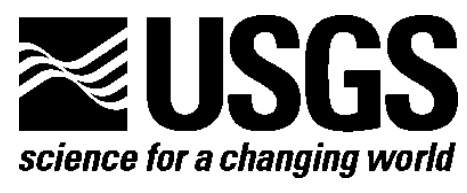

Geology and Geophysics Applied to Groundwater Hydrology at Fort Irwin, California

David C. Buesch, Editor

\title{
Lithostratigraphic Framework in Boreholes from Goldstone Lake and Nelson Lake Basins, Fort Irwin, California
}

By David C. Buesch

Open-File Report 2013-1024-D

U.S. Department of the Interior

U.S. Geological Survey 


\section{U.S. Department of the Interior \\ RYAN K. ZINKE, Secretary}

\section{U.S. Geological Survey James F. Reilly II, Director}

U.S. Geological Survey, Reston, Virginia: 2018

For more information on the USGS—-the Federal source for science about the Earth, its natural and living resources, natural hazards, and the environment-visit https://www.usgs.gov or call 1-888-ASK-USGS (1-888-275-8747).

For an overview of USGS information products, including maps, imagery, and publications, visit https://store.usgs.gov.

Any use of trade, firm, or product names is for descriptive purposes only and does not imply endorsement by the U.S. Government.

Although this information product, for the most part, is in the public domain, it also may contain copyrighted materials as noted in the text. Permission to reproduce copyrighted items must be secured from the copyright owner.

Suggested citation:

Buesch, D.C., 2018, Lithostratigraphic framework in boreholes from Goldstone Lake and Nelson Lake Basins, Fort Irwin, California, chap. D of Buesch, D.C., ed., Geology and geophysics applied to groundwater hydrology at Fort Irwin, California: U.S. Geological Survey Open-File Report 2013-1024-D, 133 p., https://doi.org/10.3133/ofr20131024D. 


\section{Contents}

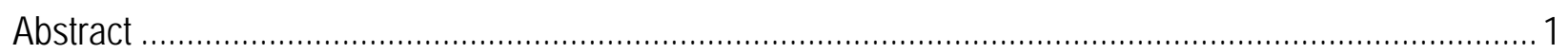

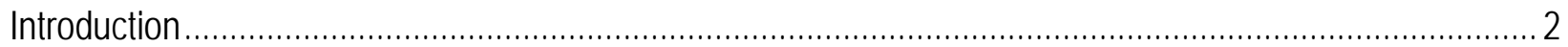

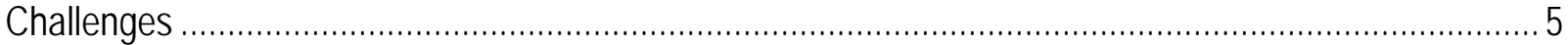

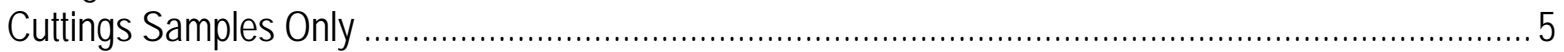

Lithostratigraphic Features in Cuttings for Age Determinations? .................................................... 5

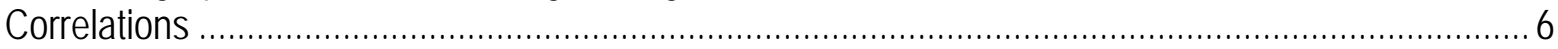

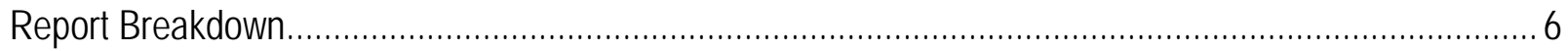

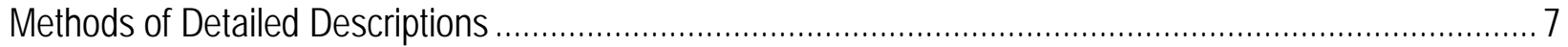

Features Included in Detailed Descriptions of Cuttings ………..................................................

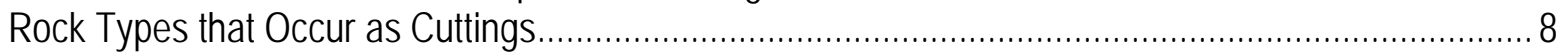

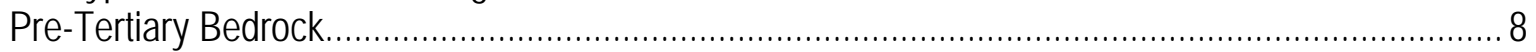

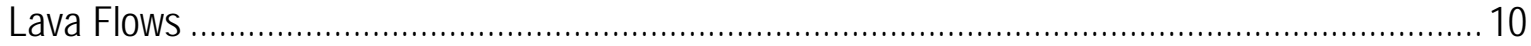

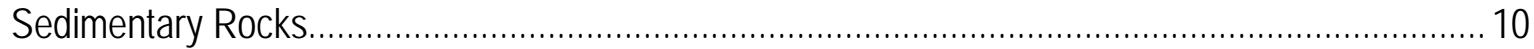

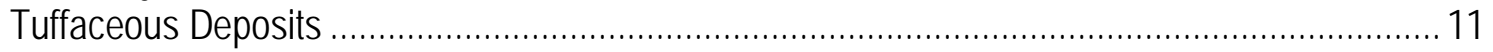

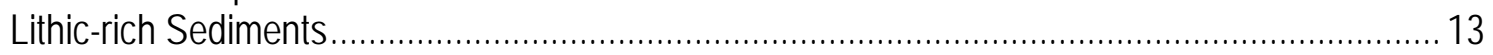

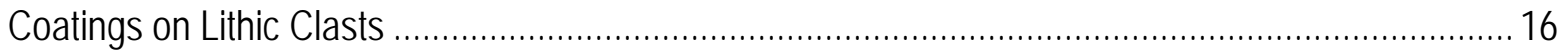

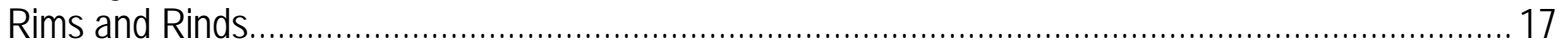

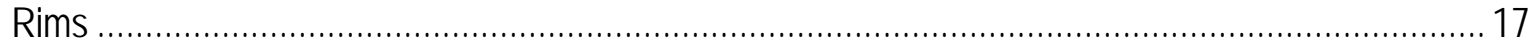

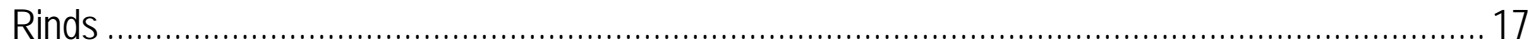

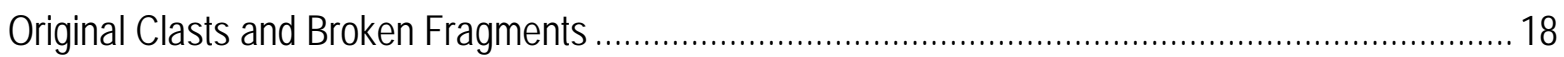

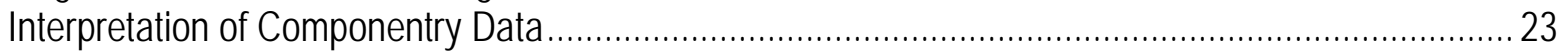

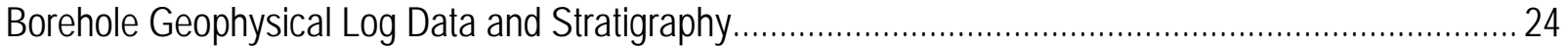

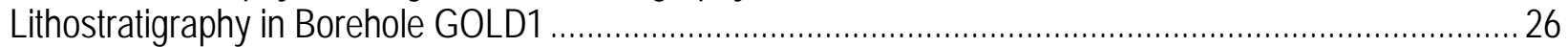

Interpretations for Lithostratigraphy in GOLD1 ..................................................................... 26

Young (Quaternary to Pliocene?) Alluvial Gravels (0-70 ft) in GOLD1 ............................................ 29

Detailed Observations on the Young (Quaternary to Pliocene?) Alluvial Gravels and Sands...........29

Miocene(?) Tuffaceous Sediments and Lava Flows (70-684 ft) in GOLD1 ..................................... 30

Miocene(?) Tuffaceous Sediments (70-294 ft) in GOLD1 ...................................................... 30

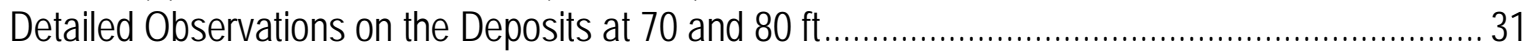

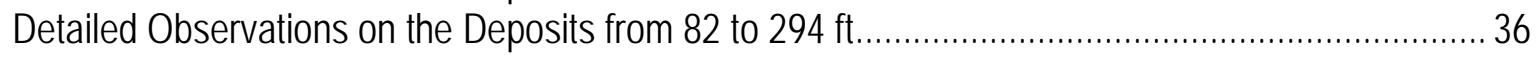

Dacite Lava Flow or Monolithic (Avalanche or Sedimentary) Breccia (294-418 ft) in GOLD1 ............. 37

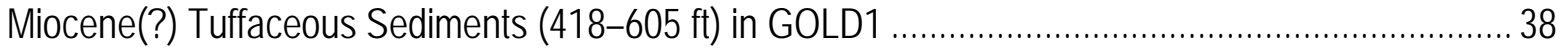

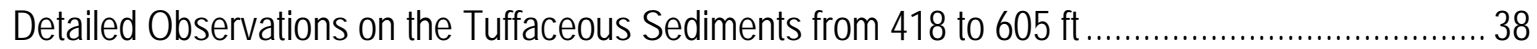

Olivine Basalt Flow (605-684 ft) in GOLD1 ..................................................................... 39

Detailed Observations on the Olivine Basalt Flows from 605 to $680 \mathrm{ft}$.......................................... 39

Summary of Lithostratigraphic Features and Units in Borehole GOLD1.............................................. 41

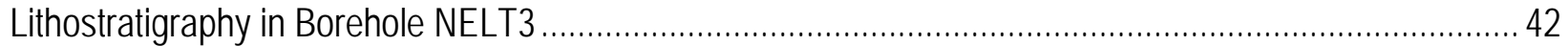

Borehole Conditions, Sample Collection, and Sample Processing.................................................... 42

Features Included in Descriptions and Logging......................................................................... 42

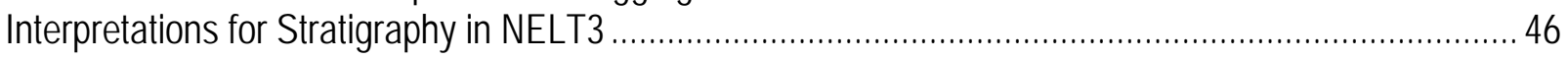

Young (Quaternary to Pliocene?) Alluvial Gravels (0-108 ft) in NELT3 ........................................... 46

Miocene Tuffaceous Sediments (108-800 ft) in NELT3......................................................... 51

Summary of Lithostratigraphic Features and Units in Borehole NELT3 ….........................................52

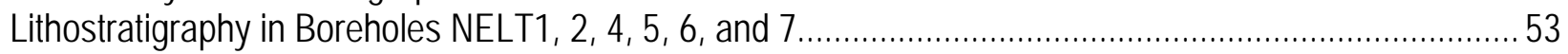

Interpretations for Stratigraphy in NELT1 .......................................................................... 54 
Young (Quaternary to Pliocene?) Alluvial Gravels (0-78 ft) in NELT1 .............................................5 54

Quaternary to Pliocene(?) or Miocene(?) Tuffaceous Sediments (78-104 ft) in NELT1 ..................... 57

Miocene Tuffaceous Sediments (104-803 ft) in NELT1 ..........................................................5 57

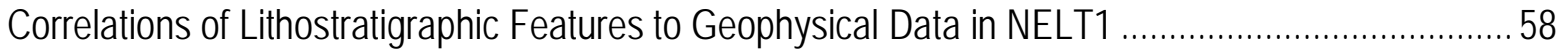

Summary of Lithostratigraphic Features and Units in Borehole NELT1 .........................................63

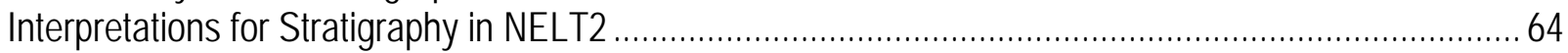

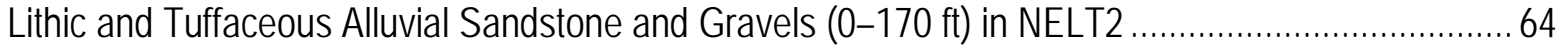

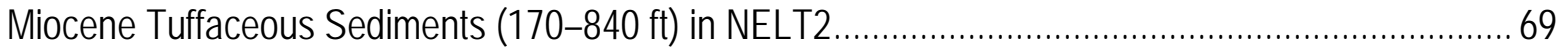

Correlations of Lithostratigraphic Features to Geophysical Data in NELT2 ......................................70

Summary of Lithostratigraphic Features and Units in Borehole NELT2 …...................................... 73

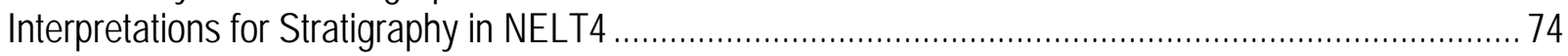

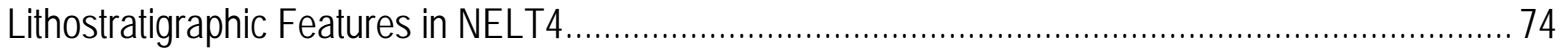

Correlations of Lithostratigraphic Features to Geophysical Data in NELT4 ….................................75

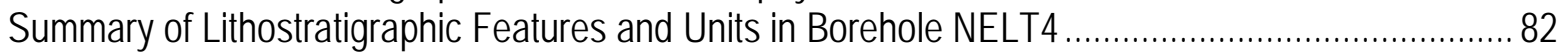

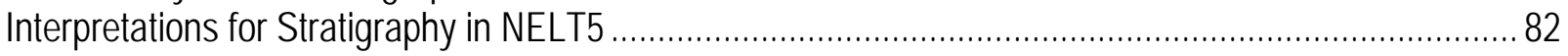

Lithostratigraphic Features and Geophysical Log Data from 50 to $130 \mathrm{ft}$ in NELT5 ......................... 83

Lithostratigraphic Features and Geophysical Log Data from 130 to $400 \mathrm{ft}$ in NELT5..........................8 86

Summary of Lithostratigraphic Features and Units in Borehole NELT5 ..........................................92

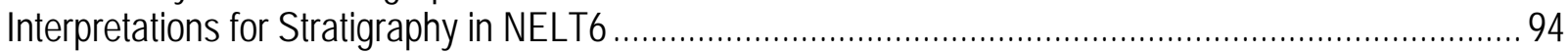

Lithostratigraphic Component Data from 60 to $400 \mathrm{ft}$ in NELT6..................................................9. 94

Correlations of Lithostratigraphic Features to Geophysical Data in NELT6 ……..............................9. 97

Summary of Lithostratigraphic Features and Units in Borehole NELT6 ............................................ 98

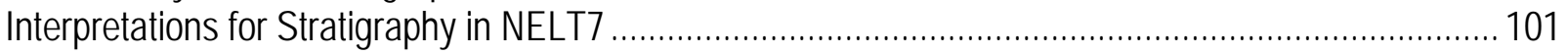

Lithostratigraphic Features and Geophysical Log Data from 50 to $86 \mathrm{ft}$ in NELT7 ......................... 101

Lithostratigraphic Features and Geophysical Log Data from 86 to $280 \mathrm{ft}$ in NELT7 ......................... 102

Summary of Lithostratigraphic Features and Units in Borehole NELT7 …….............................110

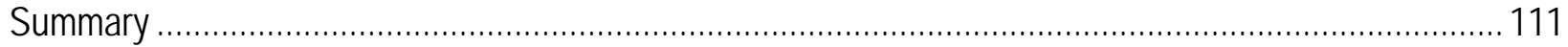

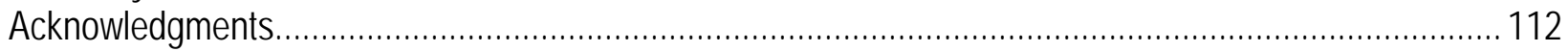

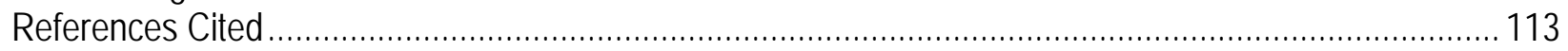

Appendix 1. Standard Sample Collection and Geophysical Data ……................................................ 115

Sample Collection and Processing....................................................................................... 115

Borehole Geophysical Log Data......................................................................................... 116

Depth Resolution of Cuttings and Core Versus Geophysical Log Data.............................................. 119

Time-domain Resistivity Geophysical Data ............................................................................. 120

Appendix 2. Componentry data of cuttings samples in eight boreholes at Fort Irwin............................... 121

\section{Figures}

1. Maps showing location, tectonic setting, and groundwater basins of Fort Irwin, California............... 3

2. Map showing the distribution of boreholes in the Goldstone Lake and Nelson Lake areas of Fort

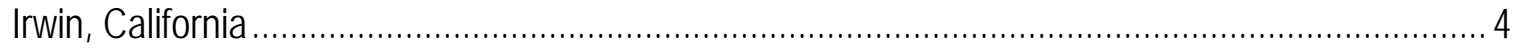

3. Field photographs of rocks at Fort Irwin, California .............................................................. 12

4. Photograph of olivine porphyritic basalt from core at 680 feet in borehole GOLD1 at Fort Irwin,

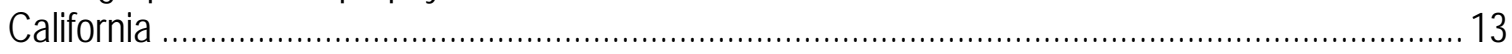

5. Photographs of cuttings of ignimbrite and lithic-rich sandstone in borehole GOLD1 at Fort Irwin,

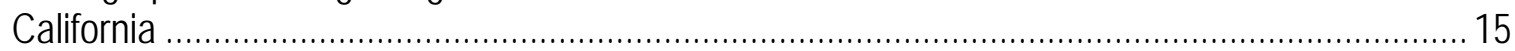


6. Photograph showing examples of clasts with fine-grained coatings from boreholes at Fort Irwin,

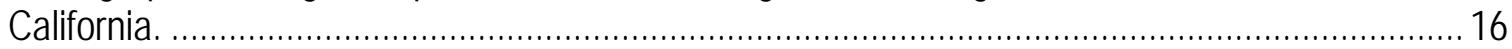

7. Photograph showing examples of grains with fractured and broken surfaces versus original

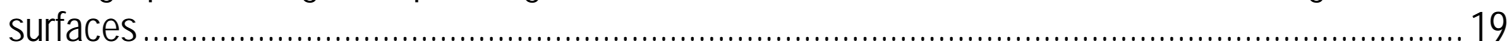

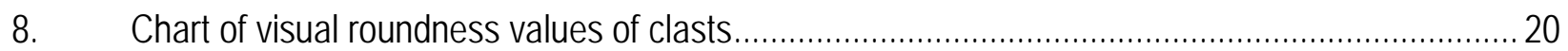

9. Chart of shape and roughness of fracture and clast surfaces................................................2 21

10. Chart showing waveform nomenclature and correlations of borehole geophysical log data...........25

11. Photographs of cuttings from the shaker table for borehole GOLD1 at Fort Irwin, California.......... 27

12. Graph showing locations of cuttings samples in borehole GOLD1 at Fort Irwin, California ............ 28

13. Bar graphs of components of cuttings samples in borehole GOLD1 at Fort Irwin, California........... 32

14. Photographs of cuttings from the shaker table for borehole NELT3 at Fort Irwin, California........... 44

15. Graph showing locations of cuttings samples in borehole NELT3 at Fort Irwin, California .............. 45

16. Bar graphs of components of cuttings samples in borehole NELT3 at Fort Irwin, California...........47

17. Photographs of cuttings from the shaker table for borehole NELT1 at Fort Irwin, California...........55

18. Graph showing locations of cuttings samples in borehole NELT1 at Fort Irwin, California ..............56

19. Bar graphs of components of cuttings samples in borehole NELT1 at Fort Irwin, California............60

20. Photographs of cuttings from the shaker table for borehole NELT2 at Fort Irwin, California............ 65

21. Graph showing locations of cuttings samples in borehole NELT2 at Fort Irwin, California .............66 66

22. Bar graphs of components of cuttings samples in borehole NELT2 at Fort Irwin, California...........67 67

23. Photographs of core from borehole NELT2 at Fort Irwin, California. ......................................... 71

24. Photographs of cuttings from the shaker table for borehole NELT4 at Fort Irwin, California............76

25. Graph showing locations of cuttings samples in borehole NELT4 at Fort Irwin, California ..............77

26. Bar graphs of components of cuttings samples in borehole NELT4 at Fort Irwin, California............79

27. Photographs of cuttings from the shaker table for borehole NELT5 at Fort Irwin, California........... 84

28. Graph showing locations of cuttings samples in borehole NELT5 at Fort Irwin, California .............. 85

29. Bar graphs of components of cuttings samples in borehole NELT5 at Fort Irwin, California............88

30. Photographs of cuttings from the shaker table for borehole NELT6 at Fort Irwin, California............95

31. Graph showing locations of cuttings samples in borehole NELT6 at Fort Irwin, California ............. 96

32. Bar graphs of components of cuttings samples in borehole NELT6 at Fort Irwin, California........... 99

33. Photographs of cuttings from the shaker table for borehole NELT7 at Fort Irwin, California.......... 103

34. Graph showing locations of cuttings samples in borehole NELT7 at Fort Irwin, California ............104

35. Bar graphs of components of cuttings samples in borehole NELT7 at Fort Irwin, California......... 106

1.1. Graph of gamma-ray data in basalt flows and tuffaceous sedimentary rocks in borehole GOLD1 at

Fort Irwin, California.

\section{Tables}

1. Location and well construction of boreholes in the Goldstone Lake and Nelson Lake basins of Fort Irwin, California.............................................................................................

2. Terms for mixed pyroclastic-epiclastic rocks at Fort Irwin, California.......................................... 11

3. Estimated depths and thicknesses of the Quaternary-Pliocene(?) and Miocene(?) sequences in the GOLD1 and NELT-series boreholes from Fort Irwin, California ............................................ 43

2.1. Table of cuttings properties in GOLD1 and NELT-series boreholes in the GOLD1 and NELTseries boreholes at Fort Irwin, California . 


\section{Conversion Factors}

International System of Units to U.S. customary units

\begin{tabular}{|c|c|c|}
\hline Multiply & By & To obtain \\
\hline \multicolumn{3}{|c|}{ Length } \\
\hline centimeter $(\mathrm{cm})$ & 0.3937 & inch (in.) \\
\hline millimeter (mm) & 0.03937 & inch (in.) \\
\hline meter (m) & 3.281 & foot (ft) \\
\hline kilometer (km) & 0.6214 & mile (mi) \\
\hline
\end{tabular}

Temperature in degrees Celsius $\left({ }^{\circ} \mathrm{C}\right)$ may be converted to degrees Fahrenheit $\left({ }^{\circ} \mathrm{F}\right)$ as ${ }^{\circ} \mathrm{F}=\left(1.8 \times{ }^{\circ} \mathrm{C}\right)+32$.

Temperature in degrees Fahrenheit $\left({ }^{\circ} \mathrm{F}\right)$ may be converted to degrees Celsius $\left({ }^{\circ} \mathrm{C}\right)$ as ${ }^{\circ} \mathrm{C}=\left({ }^{\circ} \mathrm{F}-32\right) / 1.8$.

\section{Datum}

Vertical coordinate information is referenced to the North American Vertical Datum of 1988 (NAVD 88).

Horizontal coordinate information is referenced to the North American Datum of 1983 (NAD 83).

Altitude, as used in this report, refers to distance above the vertical datum.

\section{Acronyms}

$\begin{array}{ll}\text { JRC } & \text { joint profile and roughness coefficient } \\ \text { TEM } & \text { time-domain electromagnetic } \\ \text { USGS } & \text { U.S. Geological Survey }\end{array}$

\section{Abbreviations}

$\mathrm{Ma}$ mega-annum (106 years)

\section{Geophysical Log Abbreviations}

$\begin{array}{ll}\text { cPS } & \text { counts per second } \\ \text { DELTAT } & \text { sonic geophysical log of time delay along borehole of a sonic pulse } \\ \text { Gamma } & \text { gamma log } \\ \text { mv } & \text { millivolt } \\ \text { ohm-m } & \text { ohm-meters (resistivity) } \\ \text { Res(16N) } & \text { resistivity log, 16 inch normal } \\ \text { Res(64N) } & \text { resistivity log, 64 inch normal } \\ \text { SP } & \text { spontaneous potential }\end{array}$

\section{Lithologic Abbreviations on Histogram Figures}

$\begin{array}{ll}\text { p-T } & \text { pre-Tertiary } \\ \text { OBas } & \text { porphyritic olivine basalt } \\ \text { And-Rho } & \text { andesite to rhyolite } \\ \text { Sed-T } & \text { tuffaceous sedimentary rocks } \\ \text { Sed-L } & \text { lithic-rich sedimentary rocks } \\ \text { Coat-T } & \text { tuffaceous coatings } \\ \text { Coat-L } & \text { lithic-rich coatings }\end{array}$




\title{
Lithostratigraphic Framework in Boreholes from Goldstone Lake and Nelson Lake Basins, Fort Irwin, California
}

By David C. Buesch

\begin{abstract}
In 2011 and 2012, the sedimentary basins in the Fort Irwin National Training Center, California, were evaluated for groundwater resources using a variety of techniques, including drilling of boreholes. This study summarizes lithostratigraphic features and deposits in 8 of 10 boreholes drilled in 2 basins located in the western part of Fort Irwin. The western part of Fort Irwin straddles the eastern edge of the Miocene Eagle Crags volcanic field; therefore, many of the rocks penetrated in the boreholes are primary volcanic deposits (lava flow, pyroclastic flow, and fallout tephra deposits) and tuffaceous or lithic-rich sedimentary rocks (siltstone to cobble conglomerates) deposited in alluvial, fluvial, lacustrine, and possibly groundwater discharge environments. Boreholes were drilled with mud-rotary techniques that result in cuttings samples, and only two to four cores ranging in length from 3 to 5 feet (ft) were collected in each borehole. Of the boreholes studied, maximum depths range from 684 to $903 \mathrm{ft}$. Borehole GOLD1 penetrated tuffaceous and lithic-rich sandstone, partially welded tuff, avalanche breccia, and basalt lava flows. In addition to cuttings fragments of these rocks, coatings (typically finegrained or smaller sandstone or tuff) attached to clasts can be used to approximate the type of matrix in the drilled rock. Boreholes NELT1 to NELT7, located in Nelson Lake basin, have cuttings fragments of mostly crystallized volcanic lithic clasts with minor amounts of tuff and granitic clasts. Similar to borehole GOLD1, coatings on lithic clasts are used to infer the lithicrich or tuffaceous matrix of the drilled deposits. Most rocks in these boreholes are sandstone to conglomerate that disaggregated (or were broken) during drilling.

Correlation of lithostratigraphic features to borehole geophysical logs (especially gamma and resistivity) helps to establish properties of the rock and enables identification of depositional sequences of similar rock types. Lithostratigraphic features and resistivity in boreholes compare reasonably well to nearby time-domain electromagnetic sounding (resistivity) model results.

There is no direct age control on the rocks penetrated in the boreholes. The abundance of tuffaceous material as primary or slightly redeposited matrix is used to identify rocks deposited during the activity of the Eagle Crags volcanic field in the Miocene. In contrast, sedimentary rocks composed of detrital and epiclastic grains (only a few of which are tuffaceous rocks as clasts) are inferred to have been deposited during the Quaternary or Pliocene(?). The lithostratigraphic-based estimates of relative age indicate the typical thickness of the Quaternary or Pliocene(?) deposits is $70-170 \mathrm{ft}$, and that several water-bearing horizons are probable in the Miocene(?) section.
\end{abstract}




\section{Introduction}

Fort Irwin National Training Center, California, (hereafter referred to as Fort Irwin) is located in the north-central part of the Mojave Desert and is the site of numerous geologic studies in support of hydrogeologic exploration for groundwater resources. Fort Irwin is located in the Eastern California Shear Zone (fig. 1A), an area that has experienced a complicated Neogene structural history where (1) some faults were active during the Miocene and (or) Pliocene, (2) some of these faults cut rocks as young as Pleistocene, and (3) some faults cut or deform Holocene deposits (Miller and others, 2014). The west and northwest parts of the Fort Irwin area, especially the Goldstone Lake and Nelson Lake basins and surrounding ridges (fig. 2), are locally underlain by bedrock (typically Paleozoic or older metamorphic rocks and Jurassic or Cretaceous mafic or felsic rocks) (Miller and others, 2014; Buesch and others, 2018). There are a variety of Miocene volcanic rocks and Miocene to Quaternary sedimentary rocks derived primarily from the volcanic rocks that overlie the bedrock (Miller and others, 2014; Buesch and others, 2018). Within this geologic framework, 13 groundwater basins have been studied and this study focuses on two basins in the west-northwest part of Fort Irwin where boreholes were drilled from 2010 to 2012 (Buesch, 2014; Kjos and others, 2014; fig. 1B).

The western part of Fort Irwin straddles the eastern edge of the Miocene (21-12 Ma) Eagle Crags volcanic field (Sabin and others, 1994; Schermer and others, 1996; Buesch and others, 2018; fig. 2) and, in part, this field helps establish the architectural framework for this part of Fort Irwin. The east part of the volcanic field consists mostly of primary volcanic deposits (lava flow, pyroclastic flow, and fallout tephra deposits), with volumetrically minor amounts of locally interstratified tuffaceous or lithic-rich sedimentary rocks (sandstone to cobble conglomerate or breccia), which were deposited in alluvial fan and possibly fluvial environments. East of the mostly primary volcanic rocks, there are tuffaceous or lithic-rich sedimentary rocks (siltstone to cobble conglomerates) deposited in alluvial fan, fluvial, and lacustrine environments, and groundwater discharge deposits can also be found locally.

In both the primary volcanic facies and the alluvial fan to lacustrine facies, the type of clastic fragments that occur helps constrain how deposits formed. For example, pyroclastic fragments form by disintegration of magma during an eruption, autoclastic fragments form by mechanical fracturing during movement of lava and breakage of cool brittle outer margins, and epiclasts (lithic clasts and minerals) form when they are released by ordinary weathering processes from pre-existing consolidated rocks (Fisher and Schmincke, 1984). Reworking or recycling of unconsolidated pyroclastic debris by water or wind does not transform pyroclasts into epiclastic fragments; therefore, reworked pyroclastic fragments are derived from remobilization of loose materials (Fisher and Schmincke, 1984). Many of the characteristics of these fragments can be identified in cuttings (and cores) and were used for interpretations of the type of rocks penetrated by boreholes.

Prior to the drilling by the U.S. Geological Survey (USGS) in 2010 and 2012 (Kjos and others, 2014), there were few boreholes in most of the groundwater basins, except Bicycle, Irwin, and Langford basins areas (fig. 2). With the exception of two detailed geologic maps (Yount and others, 1994; Schermer and others, 1996), the geology in the Fort Irwin area is based on compilations of regional geologic maps by Walker and others (2002a, 2002b) and more recently by Miller and others (2014). The dearth of detailed lithostratigraphic descriptions and map relations has resulted in exploration drilling in areas lacking a consistent geologic framework. In this paper, the data obtained from ongoing mapping and drilling are used to help build such a geologic framework. 
A.
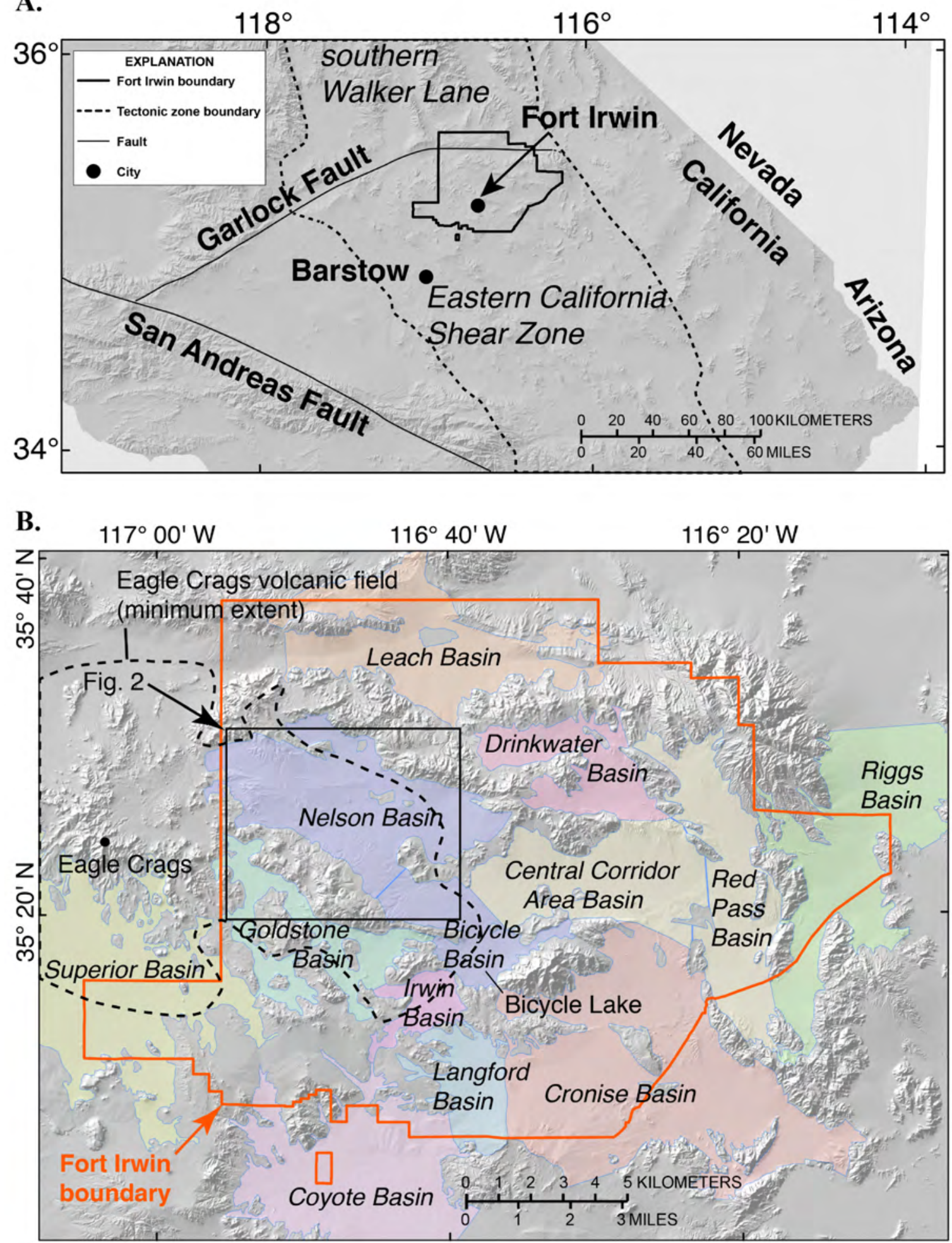

Figure 1. Maps showing location, tectonic setting, and groundwater basins of Fort Irwin, California. (A) Map showing location of Fort Irwin within the Eastern California Shear Zone. (B) Map of Fort Irwin area with groundwater basins from Buesch (2014). Universal Transverse Mercator Projection Zone 11; North American Datum of 1983. 


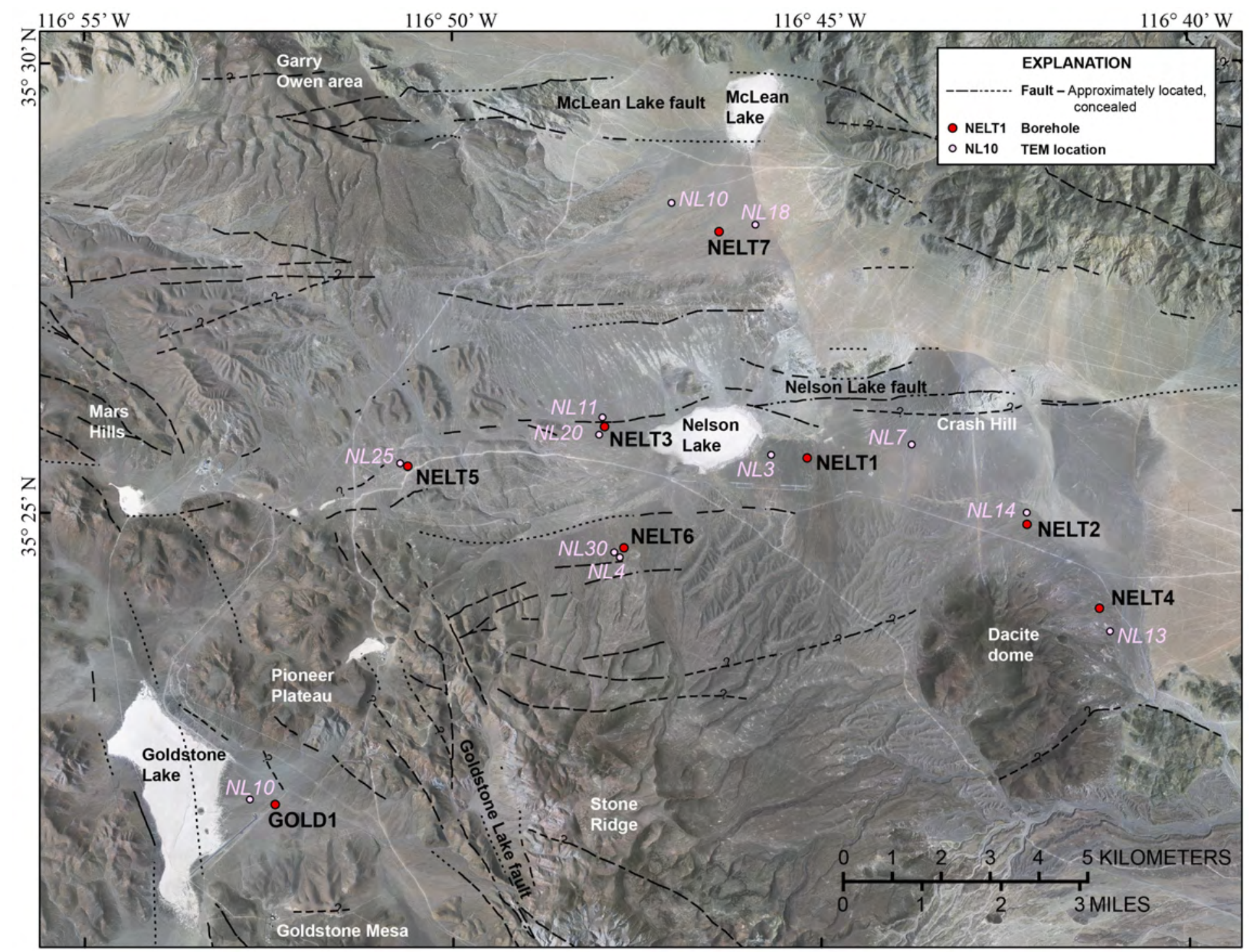

Figure 2. Map showing the distribution of boreholes in the Goldstone Lake and Nelson Lake areas of Fort Irwin, California. Photograph of large map from Fort Irwin archive. Universal Transverse Mercator Projection Zone 11; North American Datum of 1983 
Hydrogeologists and drillers from the USGS working at Fort Irwin compile a variety of logs during drilling, some of the logs and samples collected are developed and analyzed more thoroughly after drilling is completed. Some information in the following descriptions has been extracted from these logs. Descriptions in this paper are intended to complement the logs developed by the hydrogeologists and provide a slightly different perspective of the lithostratigraphy penetrated in the boreholes. As such, the sample handling and features examined in samples from boreholes differ from the methods and observations used by the hydrogeologists. In addition to the lithostratigraphic descriptions and to establishing preliminary correlations to geophysical log data, the goals of this study are to:

1. Help define variations in the lithostratigraphy, and

2. Begin development of a lithostratigraphic framework that can be used in the development of a hydrogeologic framework.

\section{Challenges}

During 2011 and 2012, 10 boreholes were drilled in the western part of Fort Irwin. Selected cuttings from borehole GOLD1, located in Goldstone Lake basin, and boreholes NELT1 to NELT7, located in Nelson Lake basin, were examined for lithostratigraphic components (table 1, fig. 2). Detailed lithologic logging was conducted with three main challenges in mind.

\section{Cuttings Samples Only}

One of the challenges was to determine lithostratigraphic features of the rocks from cuttings samples only. Most of the boreholes drilled in 2011 and 2012 used mud-rotary techniques that result in cuttings samples, and only two to four cores, 3-5 feet (ft) long were collected in each borehole.

\section{Lithostratigraphic Features in Cuttings for Age Determinations?}

In the Goldstone Lake and Nelson Lake basins, there are exposures of volcanic and sedimentary sections that contain tephra deposits that might be suitable for geochronologic studies (Buesch and others, 2018), and although some of these beds are suspected to be in the sections drilled, they are not easily identified. Without traditional geochronologic controls, the challenge was to determine whether lithostratigraphic features in the cuttings themselves might be used to determine relative and approximate age of the rocks. For example, in the Crash Hill area in Nelson Lake basin, the stratigraphic section is divided into three sequences in which different types of materials contributed to the sedimentary deposits (Buesch and others, 2018). The three-fold sedimentary sequence can be framed within the activity of the Miocene (21-12 Ma) Eagle Crags volcanic field (Sabin and others, 1994; Schermer and others, 1994) when there was abundant (and relatively frequent addition of) ash to the environment.

1. The first (oldest and stratigraphically lowest) sequence consists of "pre-volcanic" epiclastic sedimentary rocks derived from local bedrock (typically pre-Tertiary, Jurassic, or Cretaceous mafic or felsic rocks or metamorphic rocks; Miller and others, 2014; Buesch and others, 2018) with the possibility of a few tephra beds derived from distant sources.

2. The second (middle) sequence consists of "synvolcanic" rocks formed as primary volcanic rocks and sedimentary rocks derived from the primary volcanic deposits 
(especially the inclusion of tuffaceous materials) and locally from the local pre-Tertiary bedrock. In addition to the lava flows, pyroclastic flows, and fallout tephra deposits, the sediments were redeposited from surface processes (that is, debris flow or stream flow in alluvial, fluvial, or lacustrine environments). Note that there is a period of time after the end of volcanic activity in the Eagle Crags volcanic field (about $12 \mathrm{Ma}$ ) where ash was not being renewed to the landscape, and it was progressively being eroded from the hillsides. So, deposits during this period in the middle to upper Miocene were slowly transforming in composition and types of surficial processes that gave rise to the more detrital depositional features.

3. The third (youngest and stratigraphically highest) sequence consists of "postvolcanic" epiclastic sedimentary rocks derived from erosion of exposed volcanic rocks and locally from the local pre-Tertiary bedrock. In the third sequence, because there was no more addition of ash to the landscape (because the local volcanic activity has ended) and the tuffaceous materials were easily eroded, the tuffaceous materials represented a diminished resource to the detrital sedimentary sequence through time. The deposits were formed primarily from detrital-sediment surface processes such as debris flow and especially stream flow in alluvial and fluvial environments, or lacustrine environments; however, a few fallout tephra beds from distant volcanic fields have been identified (Miller and Yount, 2002).

So again, the challenge was to determine if enough lithostratigraphic features from these three sedimentary sequences in the field can also be identified in the cuttings, thereby enabling use of this three-fold classification to the rocks penetrated in the boreholes. Furthermore, and with acknowledgment that this is a very generalized framework, where the stratigraphic boundary between the "synvolcanic" and "postvolcanic" rocks can be identified, this boundary is considered to be the "top of the Miocene" section, and the "postvolcanic rocks" were probably deposited in the Quaternary to Pliocene(?).

\section{Correlations}

Another challenge was to determine possible correlations between lithostratigraphic features and borehole geophysical logs and surface-based, time-domain electromagnetic (TEM) model results.

\section{Report Breakdown}

This report summarizes:

1. The types of data collected from cuttings as part of the lithostratigraphic component analysis,

2. Types of geologic information in the GOLD1 and NELT-series boreholes,

3. Lithostratigraphic features in the boreholes,

4. Correlations of lithostratigraphic features to geophysical data, and

5. The probable best fit for the top of the mostly (Miocene) sedimentary sequence in each borehole.

The general conditions of boreholes and samples (that is, how boreholes were drilled and samples collected, handled, and described), and the standard geophysical logs collected are described in appendix 1. Descriptions of the rock types identified in cuttings, and details of lithologic features of clasts and rock fragments included in the detailed component analysis, are 
described in the "Methods of Detailed Descriptions" section. Several detailed features of clasts and rock fragments are new to the descriptions of cuttings and core and they differ from those used in the standard description methods, but are used because they provide more direct evidence of the type of rock drilled.

The eight boreholes are described in varying amounts of detail. GOLD1 is described first because it was the first borehole to be logged using the detailed component approach, but more importantly, it is located in a basin that contains mostly primary volcanic rocks and depositional facies. NELT3 is described second for two reasons. First, it was the second borehole to be logged using the detailed component approach (including refining of some sample handling methods). Secondly and more importantly, it is located in a basin that contains mostly volcanic sandstone to conglomerate deposits deposited in alluvial to fluvial environments. The other six NELT-series boreholes are described in varying amounts of detail based on a focus on the types and variations in lithostratigraphic features and units in the borehole, how well correlations of lithostratigraphic and geophysical log data can be determined, and an emphasis on determining the top of the Miocene section in each borehole.

\section{Methods of Detailed Descriptions}

The cuttings for this study are from the archived samples, and were shipped in multicompartment containers, where each container is about $40 \times 50 \times 55$ millimeters $(\mathrm{mm})$; however, they were handled in a slightly different way than those used by the USGS hydrogeologists. The cuttings were gently washed in tap water with a number 60 mesh sieve (0.25 mm, U.S.A. Standard Testing Sieve), and the fine-grained fraction that passed through the sieve was dried and stored. Gentle washing and wet sieving were used in an attempt to preserve fragments of the matrix material in the sedimentary rock that might otherwise be degraded by more aggressive treatment. Separation of drilling mud and cuttings is best done before the drilling mud begins to dry and becomes attached to the cuttings. When it begins to dry it is more difficult to distinguish drilling mud from coatings of matrix on the clasts. Cuttings were examined with hand lens and binocular microscope. Visual estimates of abundance for a variety of features (including types of fragments, phenocrysts in fragments, and the amount of matrix coating on fragments) were made by comparing the distribution of the features to charts for estimating proportions of fragments presented in GretagMacbeth (2000). Both wet sieving and visual estimates of features are simple enough to be done at the rig in support of lithologic logging, and the number and size of samples could be based on project goals.

\section{Features Included in Detailed Descriptions of Cuttings}

Cuttings can be used to identify the host rock drilled in the borehole, and the cuttings collected at 10 -ft intervals probably represent about a 2 -ft-thick segment of rock. Cuttings consist of fragments formed by fracturing and possible disaggregation of the drilled rock, so identifying features related to these two sources of cuttings is important for interpreting the features of the drilled rock. In sedimentary rocks, lithic clasts in the rock can also be fractured by drilling. In many samples described in this report, cuttings are made up of hard, typically crystallized, rocks such as lava flows, and a few welded pyroclastic flow deposits, or plutonic and metamorphic rocks and minerals. These hard materials can survive the mechanically aggressive environment of drilling. For example, if a lava flow or large cobble from a lava flow is drilled, the rock is broken into fragments, and these fragments are milled down to a size that can be removed from 
the borehole. The abundance of these hard fragments, especially if they are all compositionally the same such as a lava flow, can help identify the drilled rock. In contrast, for identification of pyroclastic and sedimentary rocks, one of the key features is the matrix of the deposit (typically ash, in the case of pyroclastic rocks, or sand-sized or smaller matrix components, in the case of sedimentary rocks). The matrix is usually the most fragile of the material and is not preserved well unless it is lithified or cemented, especially if the drilling and (or) sample handling processes are too aggressive and the cuttings are mechanically degraded or disaggregated. Aggressive handling may cause the matrix to be disaggregated into individual grains, or washed away and not retained by the sieves during sample collection or handling. In cuttings, the best opportunity for preserving the matrix of pyroclastic or sedimentary rocks occurs when samples

are carefully processed. In this case, the rock matrix can be represented by fragments of the rock, or as coatings on lithic clasts.

For this study, four main features in cuttings were evaluated during detailed examination, and they were compiled into detailed component data.

1. The type of rock that forms a fragment such as lava flow, or tuffaceous or lithic-rich sedimentary deposit.

2. Diagnostic surfaces of fragments that indicate part of the history, such as a "rim" on a fracture that formed during the cooling of a lava flow, or a "rind" consisting of a fracture lined with calcite or a calcite deposit on part of a lithic clast.

3. The type of surfaces on the fragments, including determining if a surface originally formed when the rock formed (for example, during cooling of a lava flow) or during transportation and abrasion of a clast, or was a surface broken during drilling of a rock or clast.

4. Coatings on lithic clasts that represent the type of sedimentary matrix in contact with (or hosting) the clast.

\section{Rock Types that Occur as Cuttings}

Based on in-progress mapping, rocks that form cuttings have similar (or correlative) rocks exposed in the hillsides surrounding the sediment-filled basin where the boreholes are located. The following descriptions are based primarily from rock exposures at the surface, and they emphasize the features that can be identified in cuttings. There are four basic rock types in the study area: (1) pre-Tertiary bedrock, (2) lava flows, and the sedimentary rocks: (3) tuffaceous deposits (primary or redeposited), and (4) lithic-rich sedimentary deposits. Each of these rock types can be divided into more specific rock types.

\section{Pre-Tertiary Bedrock}

The pre-Tertiary bedrock consists of igneous, metamorphic, or sedimentary and metasedimentary rocks (Miller and others, 2014). The igneous rocks are typically felsic to mafic plutonic rocks. Metamorphic rocks include gneiss, schists, and metavolcanic rocks. The sedimentary and metasedimentary rocks include carbonate-mineral rocks (marble and limestone) and siliciclastic rocks (sandstone, shale, and quartzite). 
Table 1. Location and well construction of boreholes in the Goldstone Lake and Nelson Lake basins of Fort Irwin, California. [Latitude and longitude referenced to North American Datum of 1983 (NAD83)]

\begin{tabular}{|c|c|c|c|c|c|c|c|c|}
\hline $\begin{array}{l}\text { Common } \\
\text { name }\end{array}$ & $\begin{array}{l}\text { State well } \\
\text { number }\end{array}$ & $\begin{array}{l}\text { Latitude } \\
\text { (ddmmss.ss) }\end{array}$ & $\begin{array}{c}\text { Longitude } \\
\text { (dddmmss.ss) }\end{array}$ & $\begin{array}{l}\text { Type of } \\
\text { well }\end{array}$ & $\begin{array}{l}\text { Depth } \\
\text { of well } \\
\text { (feet) }\end{array}$ & $\begin{array}{c}\text { Sand-pack } \\
\text { interval } \\
\text { (feet) }\end{array}$ & $\begin{array}{c}\text { Perforated } \\
\text { interval } \\
\text { (feet) }\end{array}$ & $\begin{array}{l}\text { Altitude of land-surface datum } \\
\text { (feet above sea level) }\end{array}$ \\
\hline GOLD1 \#1 & 15N/01E-28R1S & 352144.10 & 1165226.00 & Multiple & 670 & $631-684$ & $650-670$ & 3,055 \\
\hline GOLD1 \#2 & 15N/01E-28R2S & 352144.10 & 1165226.00 & Multiple & 580 & $534-595$ & $560-580$ & 3,055 \\
\hline GOLD1 \#3 & 15N/01E-28R3S & 352144.10 & 1165226.00 & Multiple & 370 & 328-392 & $350-370$ & 3,055 \\
\hline NELT1 \#1 & 16N/02E-34Q1S & 352535.30 & 1164510.50 & Multiple & 760 & 715-803 & $740-760$ & 3,071 \\
\hline NELT1 \#2 & 16N/02E-34Q2S & 352535.30 & 1164510.50 & Multiple & 300 & $258-321$ & $280-300$ & 3,071 \\
\hline NELT2 \#1 & 15N/03E-06L1S & 352450.80 & 1164211.30 & Multiple & 800 & 738-840 & $760-800$ & 3,048 \\
\hline NELT2 \#2 & 15N/03E-06L2S & 352450.80 & 1164211.30 & Multiple & 530 & $490-545$ & $510-530$ & 3,048 \\
\hline NELT2 \#3 & 15N/03E-06L3S & 352450.80 & 1164211.30 & Multiple & 300 & $245-313$ & $280-300$ & 3,048 \\
\hline NELT4 \#1 & 15N/03E-08L1S & 352354.90 & 1164112.50 & Single & 580 & $280-618$ & $560-580$ & 2,987 \\
\hline NELT5 \#1 & 16N/01E-35P1S & 352530.40 & 1165036.50 & Single & 840 & 437-905 & $820-840$ & 3,239 \\
\hline NELT6 \#1 & 15N/02E-05N1S & 352436.20 & 1164740.10 & Single & 840 & 355-903 & $760-840$ & 3,141 \\
\hline NELT7 \#1 & 16N/02E-16P1S & 352806.50 & 1164621.90 & Multiple & 800 & 750-865 & $780-800$ & 3,169 \\
\hline NELT7 \#2 & 16N/02E-16P2S & 352806.50 & 1164621.90 & Multiple & 640 & $592-661$ & $620-640$ & 3,169 \\
\hline NELT7 \#3 & 16N/02E-16P3S & 352806.50 & 1164621.90 & Multiple & 400 & $348-421$ & $380-400$ & 3,169 \\
\hline
\end{tabular}




\section{Lava Flows}

There is a wide range in textures and compositions of lava flows, domes, and locally, dikes in the vicinity of the study area (Buesch and others, 2018). Sabin and others (1994) also describe shallow intrusions in the Eagle Crag volcanic field. Lava flows exposed at the ground surface range from basalt to rhyolite, and most have identifiable tops, bottoms, and internal cores (fig. 3A). Most lava flows have tops and bottoms that differ in the size, shape, and abundance of vesicles compared to cores, and many have rubble (or clinker) at the top and (or) bottom. Some basalt flows have tops and (or) bottoms with "ropy" flow structures indicating they were pahoehoe flows. Fracture characteristics such as orientation, spacing, and surface geometry can differ from top to core to bottom of the lava flow. In hand specimen, and in core from borehole GOLD1, the olivine basalt flows have a well-developed porphyritic texture of the olivine phenocrysts in a fine-grained groundmass (fig. 4). Andesite, dacite, and rhyolite lava flows can be aphanitic (with no visible crystals), or they can be porphyritic with one or two feldspars, pyroxene, hornblende, or biotite phenocrysts in a very fine-grained aphanitic groundmass. During the early stages of this study, for most samples in boreholes GOLD1 and NELT3, lithic fragments were identified by specific rock type and petrologic features (for example, porphyritic olivine basalt, crystallized porphyritic dacite, vitric vesicular rhyolite). Although this information can be useful in determining provenance of the deposits, it is not only difficult to determine provenance for such small fragments (typically less than 5-10 mm), but also time consuming, and this type of information was not directly applicable to the current hydrogeologic purposes. For hydrogeologic purposes, the volcanic rocks near Fort Irwin have been divided into basalts (especially porphyritic olivine basalts) and andesites to rhyolites, and a categorization based on the general characteristics of the lava flows such as typical fracture networks and the thickness and length of flows (Buesch and others, 2018). For example, porphyritic olivine basalt flows are relatively thin and widespread with well-developed columnar joints, whereas the andesite, dacite, and rhyolite flows are thick and short (many are domes) with variably integrated fracture networks formed during cooling. Many sparsely porphyritic basaltic andesites have field characteristics that are closer to andesite than olivine basalt. Therefore, the compositional components of cutting fragments in GOLD1 and NELT3, and the subsequent borehole studies, were generalized into the categories of Olivine basalts (OBas) and Andesites to Rhyolites (AndRho), which includes basaltic andesite.

\section{Sedimentary Rocks}

In field exposures, as a general description and specifically in the Fort Irwin area, sedimentary rocks consist of primary pyroclastic deposits, such as pyroclastic flow deposits (which are also referred to as ignimbrites) and fallout tephra deposits, and sedimentary deposits from surficial processes such as avalanches, debris flows, stream flows, and settling in bodies of water (Fisher and Schmincke, 1984; Buesch and others, 2018; fig. 3B, $C, D$ ). For many of these deposits, interpretations of how the rocks formed are based on the textures and structures of the deposits and field relations, such as lateral continuity, variations in thickness, onlap relations, and relief of topography that the deposit can be traced across. These field relations cannot be determined in boreholes (especially with cuttings), so smaller features such as textures, grain sizes, and compositions are important crossovers between field-based and borehole-based identification and categorization of both tuffaceous deposits and lithic-rich (or epiclastic) sedimentary deposits. This categorization focuses on the grain size and grain size distribution of 
the pyroclastic or sedimentary rocks, and composition of the clasts. The grain size and composition in the matrix, including other features such as fabric and (or) grading of the clasts, are especially important when using cuttings because cuttings are typically less than $8 \mathrm{~mm}$, and many features of the matrix form the basis for the classification of coatings on lithic clasts used in this report. Grain sizes range from cobbles and boulders (grains larger than $64 \mathrm{~mm}$ ), through pebbles (2-64 mm), through sand (0.0625-2 mm), to silt and clay (less than $0.0625 \mathrm{~mm}$ ), and for pyroclastic or tuffaceous rocks the equivalent sizes are block, lapilli, ash, and dust (also referred to as fine ash) (Fisher and Schmincke, 1984). In both pyroclastic and sedimentary rocks (including redeposited pyroclastic and epiclastic rocks), the matrix is a relative term for the finergrained material that encompasses larger grains. Composition provides a classification based on the amounts of pyroclastic and epiclastic grains. Fisher and Schmincke (1984) refer to (1) pyroclastic rocks (tuff, lapillistone, agglomerate, or pyroclastic breccia) as having 75-100 percent pyroclasts, (2) tuffites (mixed pyroclastic-epiclastic rocks such as tuffaceous sandstone and tuffaceous conglomerate) as having 25-75 percent pyroclasts, and (3) epiclastic rocks (mudstone, siltstone, sandstone, conglomerate) as having 0-25 percent pyroclasts. The general compositional classification system of Fisher and Schmicke (1984) has been adopted and slightly revised for rocks in the Fort Irwin area that are exposed at the ground surface and in boreholes (table 2). The main adaptation was to divide the three categories into six categories. In general, these divisions work well in the Fort Irwin area; however, in some stratigraphic sequences, a more locally definitive value for the lithic-bearing tuff threshold can be 20 percent or 30 percent lithic clasts, so the 25 percent should probably be $25 \pm 5$ percent.

\section{Tuffaceous Deposits}

Tuffaceous deposits (which are represented in figures in this study as Sed-T) consist mostly of pumice clasts and ash shards ranging in size from lapilli to ash and (or) dust, along with various amounts of crystal or lithic clasts (fig. $3 C$ ). Tuffaceous matrix consists of very fine to coarse grains of dust and ash, and individual grains are typically glass shards or pumice clasts with minor amounts of crystal or lithic clasts. In field exposures, and in boreholes with core or large fragments in cuttings, if samples are large enough, lapilli typically are pumice clasts; however, some lapilli-sized clasts can be lithic fragments. Tuffaceous matrix is divided into lithic-poor and lithic-bearing. (1) Lithic-poor matrix contains less than 10 percent crystal and lithic clasts, and typically, crystal clasts are more abundant than lithic clasts. (2) Lithic-bearing tuffaceous matrix is similar to lithic-poor tuffaceous matrix; however, there are 5-15 percent each of crystal and lithic clasts (but typically, the total is less than 25 percent), and either crystals or lithic clasts can be more abundant.

Table 2. Terms for mixed pyroclastic-epiclastic rocks at Fort Irwin, California.

\begin{tabular}{ccll}
\hline Pyroclast percent & Epiclast percent & \multicolumn{1}{c}{ Rock name } & \multicolumn{1}{c}{ Matrix description } \\
\hline $90-100$ & $0-10$ & Tuff & Tuffaceous matrix \\
$75-90$ & $10-25$ & Lithic-bearing tuff & Lithic-bearing tuffaceous matrix \\
$50-75$ & $25-50$ & Lithic-rich tuffaceous sandstone & Lithic-rich tuffaceous matrix \\
$25-50$ & $50-75$ & Pumice-rich (lithic) sandstone & Pumice-rich lithic matrix \\
$10-25$ & $75-90$ & Pumice-bearing (lithic) sandstone & Pumice-bearing lithic matrix \\
$0-10$ & $90-100$ & (lithic) sandstone & Lithic matrix \\
\hline
\end{tabular}


A

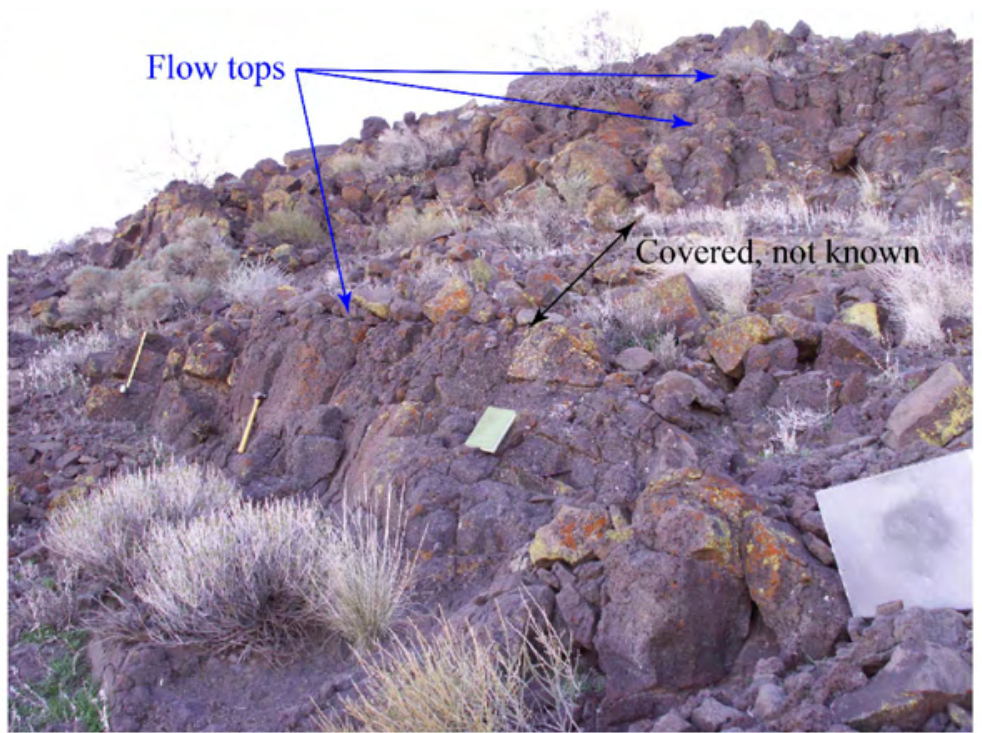

C

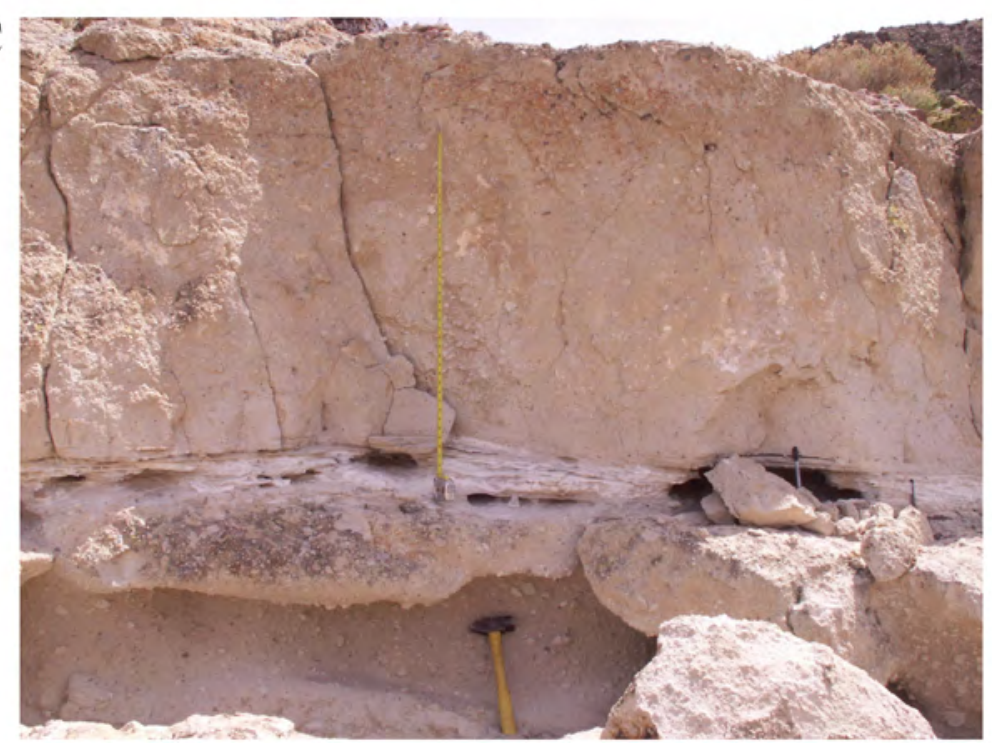

$\mathrm{B}$

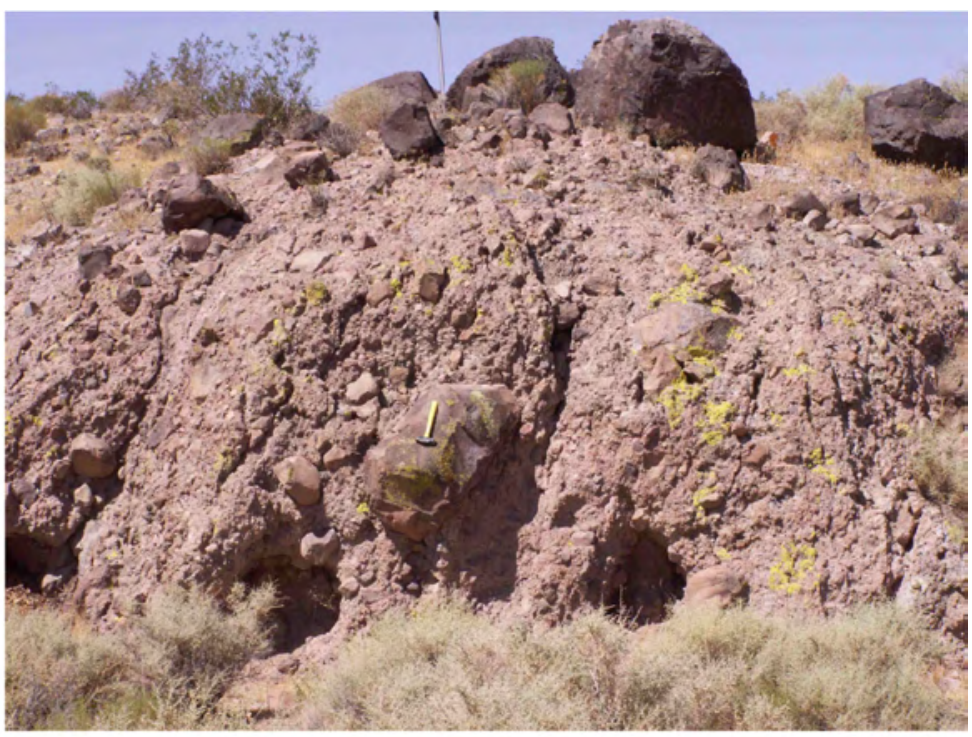

$\mathrm{D}$

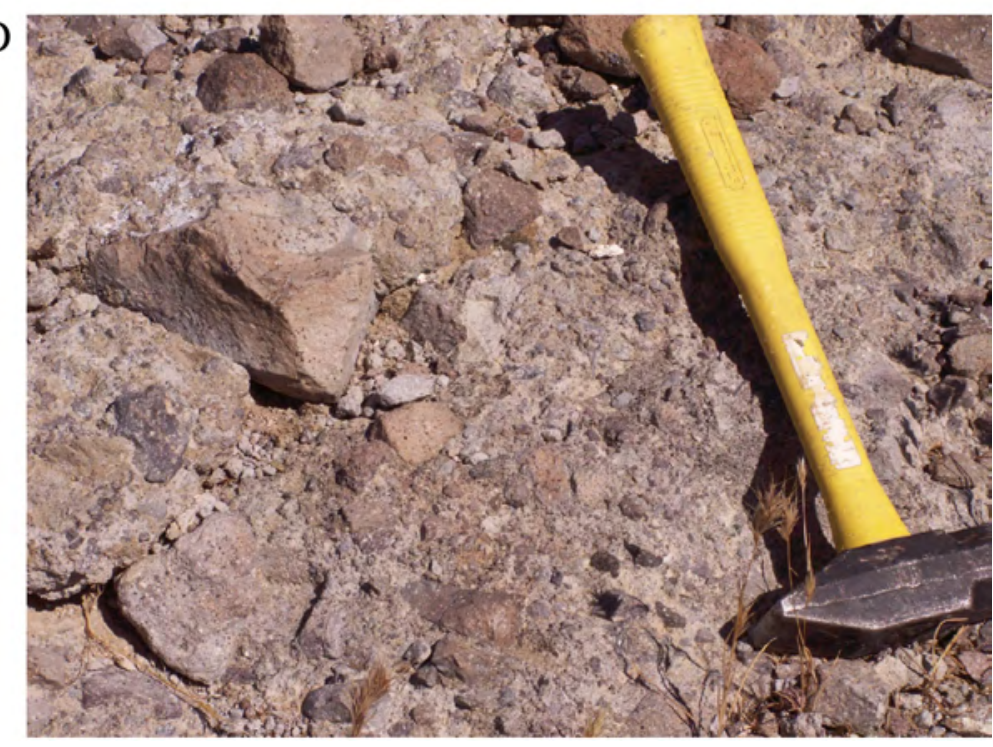

Figure 3. Field photographs of rocks at Fort Irwin, California. $A$, olivine basalt flows; $B$, avalanche breccia; $C$, tuffaceous deposits of ignimbrite with interbedded bedded tuff; and $D$, lithic-rich conglomerate/breccia. Hammer handle and head is 35 centimeters. 


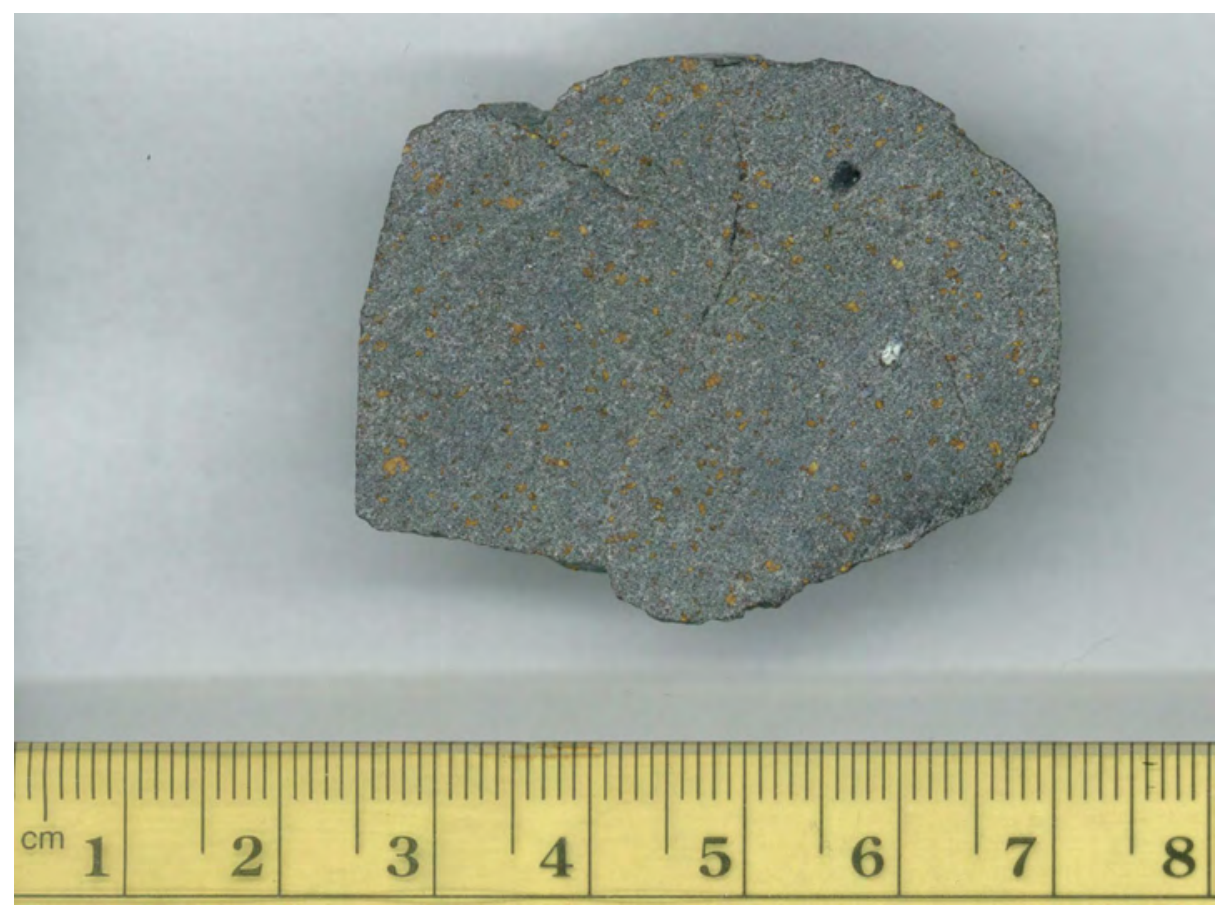

Figure 4. Photograph of olivine porphyritic basalt from core at 680 feet in borehole GOLD1 at Fort Irwin, California.

Tuffaceous matrix typically occurs in primary pyroclastic deposits; however, tuffaceous matrix can also occur where pyroclastic material has been transported and redeposited shortly after initial deposition in an alluvial or fluvial environment where mechanical segregation of clast sizes has not been very effective. Typically, the finest grained material is white to pinkish white to very pale brown or pale yellow. In rocks where the glass has not altered, the grains are vitreous and translucent. In some ignimbrites that are partially to densely welded, the original glass has crystallized at high temperature (usually greater than $600{ }^{\circ} \mathrm{C}$ as a type of devitrification) to very fine-grained feldspar, quartz or cristobalite with small amounts of iron oxides (fig. 5A). In tuffaceous deposits where the original glass was partially to completely altered to zeolite(?) or clay(?) minerals, the material has a waxy luster and the clastic textures of the dust to fine-grained ash can be obscured. Where the matrix has been altered, the original coarser grains (typically pumice clasts) can have a similar appearance to the finer material, but the coarser-grained clastic texture and sorting is preserved. In most tuffaceous rocks, the altered material is not fractured, and this implies that it is not composed of expansive clay minerals. However, at the submillimeter scale, some altered materials have minor amounts of fracturing, and this fracturing implies at least some expansive clay minerals are in the rocks.

\section{Lithic-rich Sediments}

Lithic-rich deposits (represented in figures as Sed-L) have greater than approximately 25 percent lithic, crystal, and (or) pumice clasts (fig. 3D). Some lithic-rich deposits are moderately lithified or cemented, whereas others are friable and can be easily disaggregated. The more friable material occurs most frequently in younger deposits and in shallower parts of boreholes; however, they can occasionally occur in older parts of the section. Lithic-rich matrix consists of lithic, crystal, or pumice clasts as coarse silt- to sand-sized grains, with lithic and (or) pumice 
clasts typically more abundant than crystal clasts (fig. 5B). Lithic-rich matrix is divided into lithic-rich and pumice-lithic-rich. Lithic-rich matrix has greater than approximately 25 percent (and as high as 100 percent) lithic and (or) crystal grains in a very fine-grained matrix. Lithic clasts are typically more abundant than crystal clasts. Pumice-lithic-rich matrix differs from lithic-rich matrix in grain composition, most grains are rounded pumice clasts. The two matrices are similar in the large percentage of sand-sized grains that occur. In many samples, very fine- to coarse-grained glass shards (dust to ash) form the fine-grained matrix, and pumice clasts can form individual grains. Typically, pumice clasts are distinctly different than glass shards, indicating they were not co-erupted.

Some epiclasts consist of tuffaceous rock fragments. In field exposures and boreholes with core or large fragments in cuttings, if samples are large enough, lapilli- or pebble-sized clasts can be lithic, pumice, or tuffaceous rock fragments. In field exposures, clasts can be block or cobble to boulder in size. The main textural feature of lithic-rich matrix, as used in this paper, is better sorting of the sand-sized particles compared to tuffaceous matrix. Where granular texture and sorting of matrix are preserved, even where the grains are mostly rounded pumice clasts (that is, the grains appear to be detrital clasts), the material is attributed to a lithic-rich matrix.

Typically, the finest grained lithic-rich matrix is white to pinkish white or pale yellow. In rocks where the glass has not altered, the grains are vitreous and translucent. As with tuffaceous matrix, where the original glass is partially to completely altered to zeolite(?) or clay(?) minerals, the material has a waxy luster and the clastic textures of the finest grained materials can be obscured. Unlike tuffaceous matrix, except for the finest grain sizes, the clastic textures of most of the lithic grains are identifiable because they are better preserved. As with tuffaceous matrix, in most lithic-rich matrix rocks, the altered material is not fractured. However, at the submillimeter scale, some altered materials have minor amounts of fracturing, and this fracturing implies there are expansive clay minerals in these rocks.

Although lithic-rich matrix can occur in primary volcanic deposits (inferred to result from phreatic explosions or avalanches), it is probably more indicative of material that has been transported and redeposited in an alluvial or fluvial environment, where the mechanical segregation of clast sizes has been effective. Considering the observations discussed above, the lithic-rich matrix is derived from either (1) lithic clasts, left after fine ash particles were winnowed from the sediment by surface processes (such as by streams), or (2) exposed hard rocks, such as lava flows, or locally the pre-Tertiary plutonic and metamorphic rocks that weather to form epiclastic detrital fragments. 


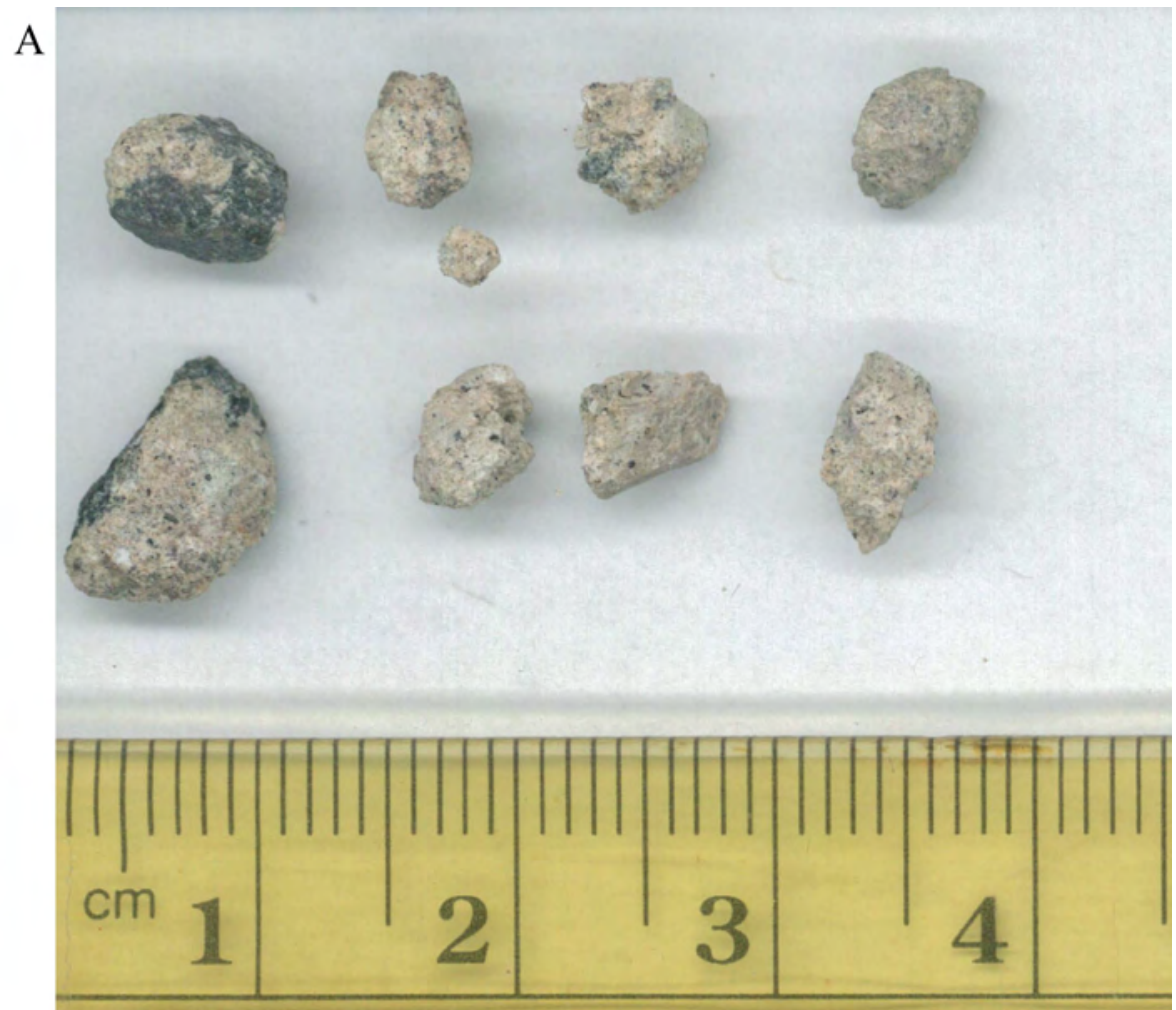

B

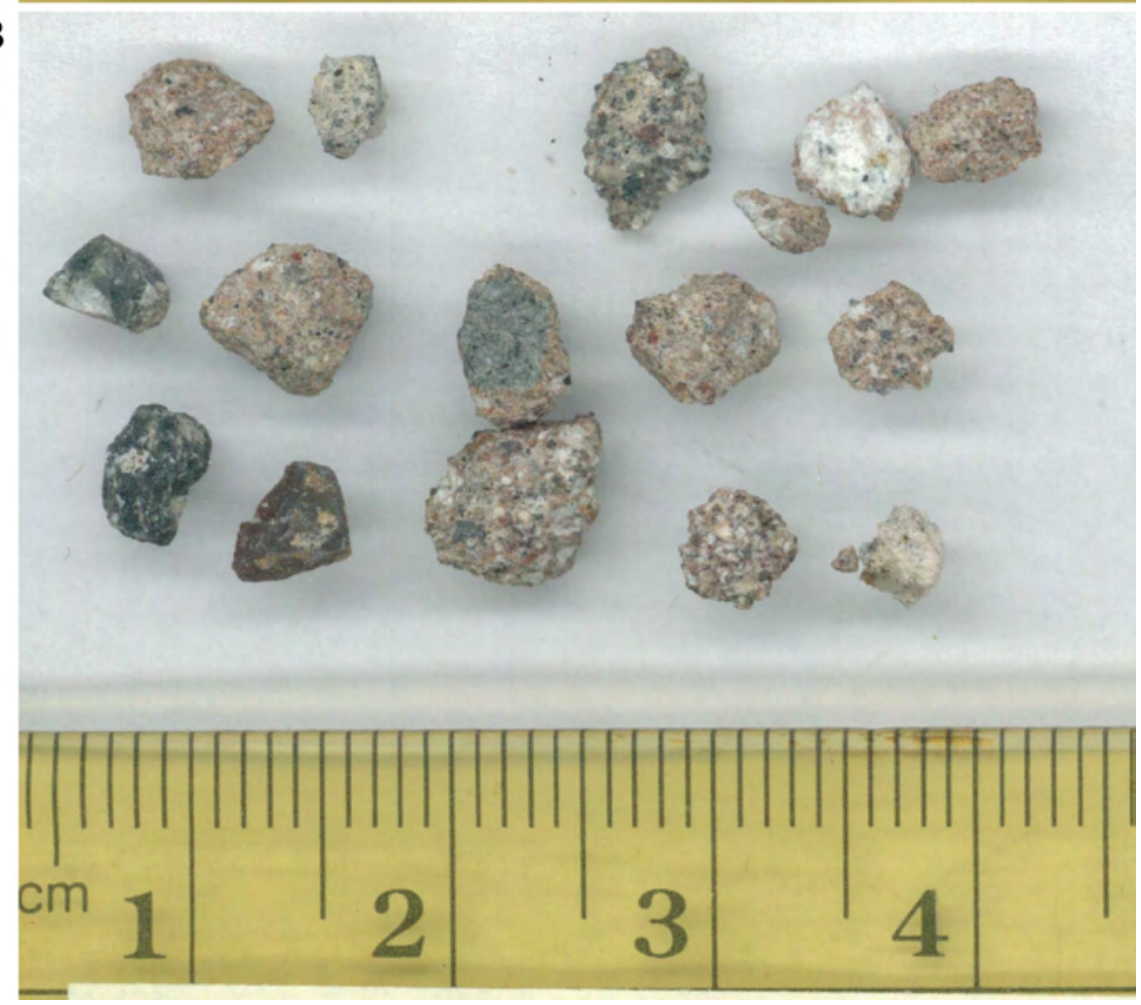

Figure 5. Photographs of cuttings of ignimbrite and lithic-rich sandstone in borehole GOLD1 at Fort Irwin, California. A, lithic-bearing, partially welded, and crystallized ignimbrite at 540 feet. $B$, lithified pebbly sandstone at 580 feet. Lithic clast fragments in the center and lower left of the image have matrix attached to the clast. 


\section{Coatings on Lithic Clasts}

Lithic clasts can be partially coated with fine- to medium-grained tuffaceous or lithic-rich sedimentary material referred to as "coatings" in this report (fig. 6). Coatings are interpreted as representing the matrix of the sedimentary deposit. They are typically $0.1-0.5 \mathrm{~mm}$ thick, but can be as thick as $2 \mathrm{~mm}$. Coatings have the same classifications as the sedimentary rocks. Tuffaceous coatings (represented in figures as Coat-T) are divided into very fine- to fine-grained (1a) lithicpoor, or (1b) crystal- or lithic-bearing. Lithic-rich coatings (represented in figures as Coat-L) are divided into (2a) lithic-rich or (2b) pumice-lithic-rich. Coatings are on original clast surfaces; however, not all original surfaces have coatings. Coatings on individual clasts cover as much as 40 percent of the original surface. The relative abundance of each coating type is used to infer the matrix of the rock. For example, a sample can have 15 percent total coatings with 8 percent (lithic-poor) tuffaceous, 2 percent lithic-bearing, 4 percent pumice-lithic-rich, and 1 percent lithic-rich (as displayed in the component diagrams, and in table 2.1); however, the ratios would be 54, 13, 27, and 7 percent, respectively.

The evidence for coatings being representative samples of the surrounding matrix was first demonstrated in borehole GOLD1. Many collocated samples from this borehole had both abundant fragments of the sedimentary rock matrix and coatings with similar textures and compositions. It was therefore inferred that coatings can be used to identify the matrix of the surrounding rock at the depth of borehole penetration. In contrast, numerous boreholes in the NELT-series have samples with few coatings, and some have few or no identified fragments of sedimentary rock. In these boreholes, the minimal amounts of coating indicate the rock matrix is soft and can be easily degraded or disaggregated during drilling or sample handling.

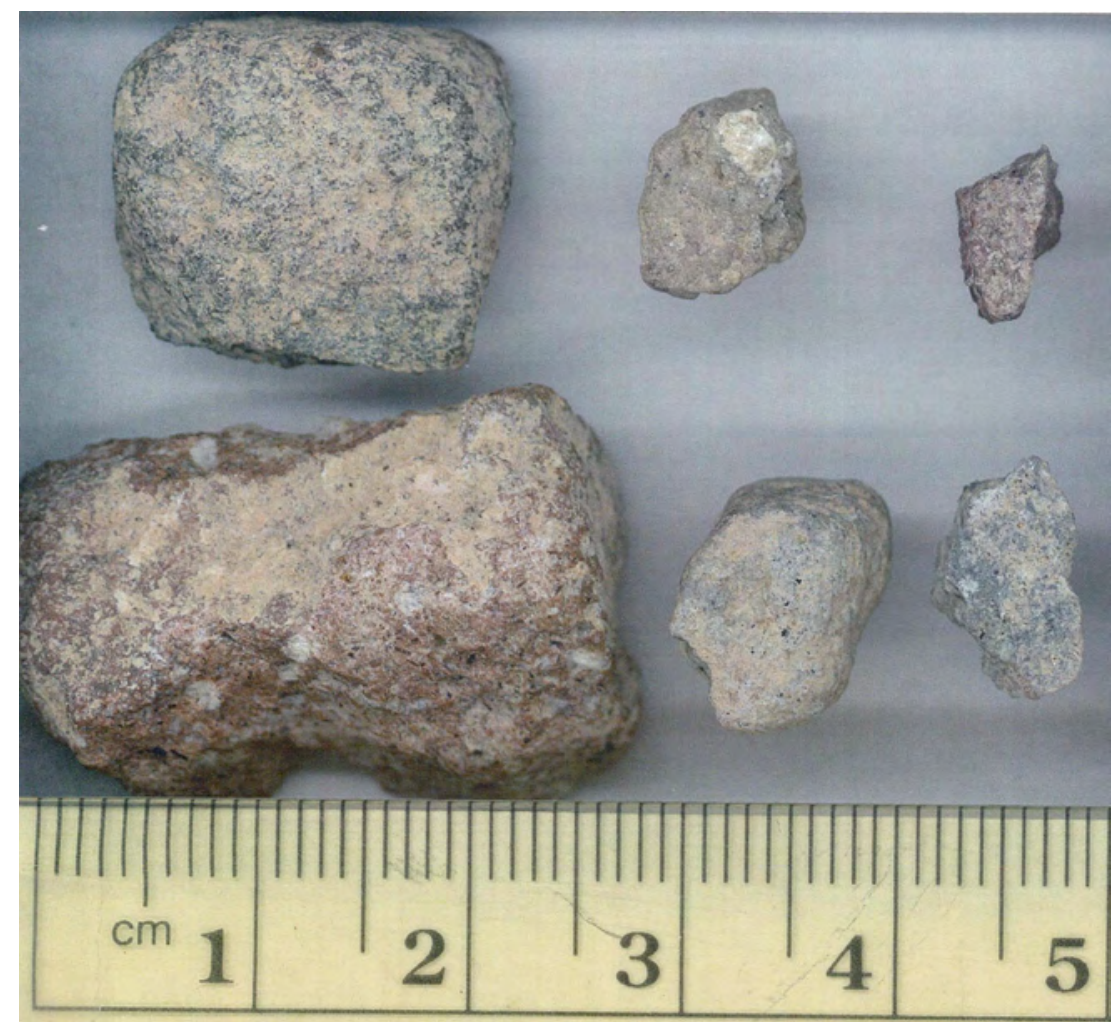

Figure 6. Photograph showing examples of clasts with fine-grained coatings from boreholes at Fort Irwin, California. 


\section{Rims and Rinds}

There are two types of features on the surfaces of fractures or clasts that form under specific petrologic conditions. These features are "rims" that formed from the crystallization of glass during the early cooling of lava flows and ignimbrites, and "rinds" that formed from precipitation of minerals from water in either the saturated or unsaturated zones.

\section{Rims}

Rims are thin zones of crystallization along the fractures or cavities in lava flows and welded ignimbrites that formed very soon after deposition when the deposit was cooling (Buesch and others, 1996; Buesch and others, 1999; Buesch, 2005). For example, in the vitric or crystallized ignimbrites and lava flows at Yucca Mountain, Nevada, rims are typically thin (1-15 $\mathrm{mm}$, and locally up to $30 \mathrm{~mm}$ ), light gray to white, and consist mostly of feldspar spherulites that grew from the wall of fractures or lithophysal cavities into the surrounding host rock. Borders are similar to rims, and are thin (1-3 mm), reddish purple, fine-grained crystallization that formed either adjacent to (or instead of) rims. Borders differ from the crystallization in the surrounding host rock (Buesch and others, 1996; Buesch and others, 1999; Buesch, 2005).

Rims and borders provide insight into the early history of the cooling volcanic deposit, because they only form when vapor in fractures or lithophysal cavities interacts with the glassy host rock. As the rock and vapor cool, including after the rock mass crystallizes, the vapor precipitates vapor-phase minerals onto the exposed face of fractures and cavities, so vapor-phase minerals also form during specific periods of time in the rock history. During both the pre- and post-crystallization of the rock, the vapor phase can oxidize susceptible minerals along fracture or cavity walls. Oxidation can also occur well after the rock has cooled, as a result of the interaction with water or vapor flowing through the rock. Oxidation, therefore, is not a unique feature to help constrain the time when a fracture formed.

In the volcanic rocks of the Fort Irwin area, rims and borders have been identified on a variety of andesitic to rhyolitic lava flows, and typically they are thin (usually less than 1-2 mm). Some olivine basalt lava flows have slightly different crystallization along what appear to be cooling joints, compared to the internal parts of the rock. Rims and borders in andesitic to rhyolitic flows, and parts of cooling joints in basalts, have been identified in the cuttings from boreholes used in this study. Fractured rock fragments that have a rim or border on one surface help to distinguish naturally formed fractures from those formed during drilling.

\section{Rinds}

Rinds are typically fine-grained, thin (usually less than 1-3 mm), light colored, and usually consist of calcite, and possibly opal, chalcedony, or quartz. Rinds form (1) on the walls of fractures or other cavities, where the minerals grow from the wall into the cavity space, or (2) on the surfaces of lithic clasts in sedimentary rocks, where the minerals grow into the surrounding matrix. Rinds can form from precipitation from water in either the saturated or unsaturated zones. In the unsaturated zone, rinds are typically associated with pedogenic carbonate deposits. On some clasts, there are rinds that formed on the rock, and then the rock and rind (combined) became a clast that was abraded and rounded during transport. These clasts with old rinds are good evidence of a polycyclic history of a clast. Although not the same as a rind, root casts and rhizoliths (or rhizoconcretions), which usually consist of calcite, occur in various 
sedimentary deposits in the Fort Irwin area. Fragments of root casts and rhizoliths also occur in some of the cuttings from boreholes.

\section{Original Clasts and Broken Fragments}

The shapes and type of surfaces on lithic clasts and fragments in cuttings are used to infer the amount of primary fractures on clasts (which might include having rims and borders) and clast rounding, and the amount of fracturing during drilling. The goal is to separate the geologic history from the drilling history of the cuttings in order to focus on the lithostratigraphic framework in the borehole.

In this study, the types of surfaces are categorized as "original” where the surface was part of the clast prior to sampling (drilling) and "broken" where the surface was formed during sampling (or drilling) (fig. 7). Part of the characterization of original and broken surfaces includes the detailed shape and geometry of the surfaces on a clast or fragment. The features of an original surface can be many, and they represent the history of the clast. For example, shortly after the time of emplacement of a lava flow, it cools and fractures, and the fractures might have various orientations and features (such as a rim or border, or just a fine-grained edge to the fracture surface). The rock might become broken because of nearby faulting. If the rock was buried, then water percolating past the fractures can alter the rock or precipitate minerals. At some point, the rock is exposed at the ground surface to surficial weathering (which might induce fracturing), and ultimately pieces (fragments) are dislodged from the exposure. In order for the fragment to be dislodged, it either has to form new fractures along which it can be separated from the exposure, or existing fractures are the zones of weakness along which the fragment can be dislodged. These fractures record the size, spacing, orientation (at least relative to the bounding fractures of the fragment), crystallization or mineralization, and structural history of the fragment. All of these fracture features of the fragment are the beginning point for the modifications of a sedimentary clast by surficial processes (primarily abrasion, which results in rounding and "frosting" of a surface, and possibly fracturing from grain-to-grain impacts). Finally, original clast surfaces can have attached matrix or coatings.

In general, all lithic clasts in pyroclastic and epiclastic sedimentary deposits began as a fragment bounded by fractures, and then the fracture surfaces were modified during transportation and deposition. In contrast, surfaces broken during drilling crosscut original clast surfaces, the intersection of a broken surface with another surface is sharp (not abraded), and they do not have any attached matrix or coating. One caveat about a fracture surface that needs to be considered when identifying and classifying it as a drilling-induced broken surface is that it is possible the fracture formed in a clast on a surficial deposit in the geologic past. Clasts exposed at the ground surface can become fractured by weathering, freeze-thaw wedging, and (or) thermal expansion and contraction, and these fractures transect the original clast surface (many at sharp angles). These old fractured clast surfaces typically do not look as fresh as a drillinginduced break; they might be slightly frosted because of weathering, and they can have attached matrix or coating because they were included in the sedimentary deposit that covered the clast. 


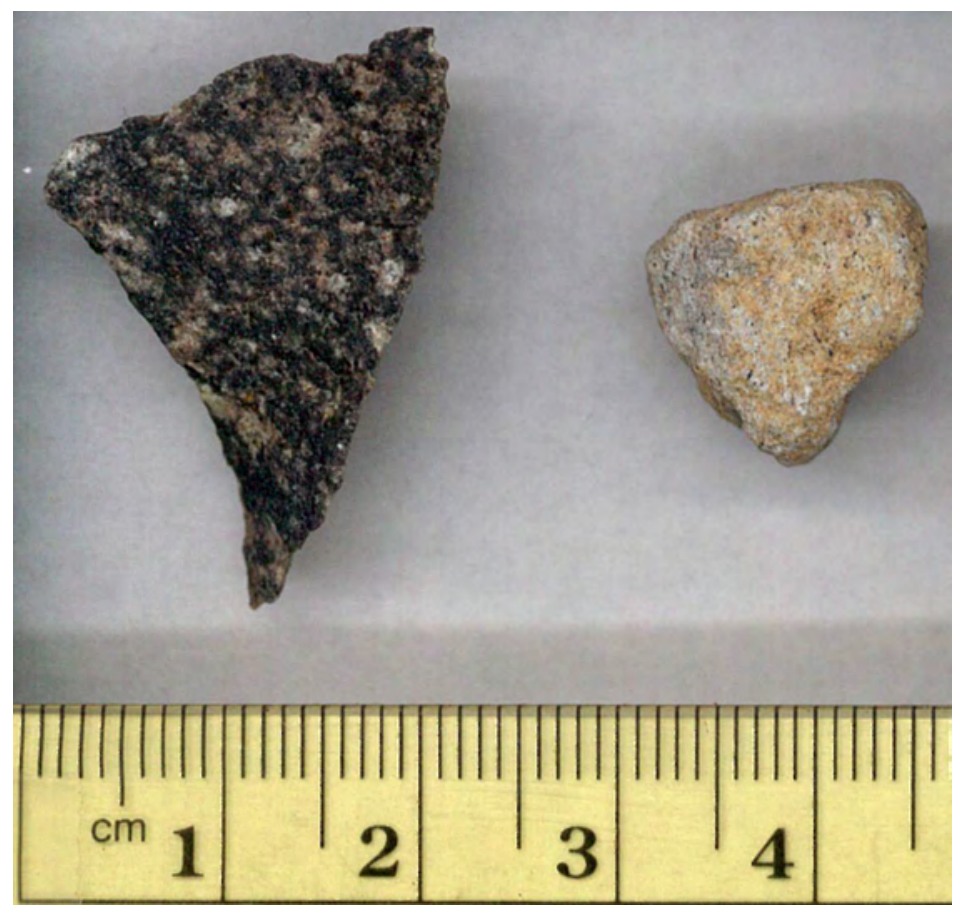

Figure 7. Photograph showing examples of grains with fractured and broken surfaces (left) and original surfaces (right).

For lithic clasts and fragments, the percentages of surface area of original clast surface versus newly broken surface by drilling were visually estimated and compared to graphical depictions of abundance in GretagMacbeth (2000). Examination of cuttings was done with hand lens, magnifying glass, and a 7-30× magnifying dissecting scope. Selected samples in most boreholes had estimates for individual clasts and fragments (table 2.1). The number of grains per sample varied and the intent was to examine representative clasts or fragments. The number of surface types (original and broken) was counted, and the area of each surface type was estimated as a percentage of the total surface area. These individual grain data were supporting data for the bulk estimates of a sample. Additionally, all samples in all boreholes had bulk estimates of original versus broken surfaces (table 2.1). These estimates were done by pouring the washed cuttings samples onto a white paper with grains only one or two deep such that all grains were visible.

The shapes of surfaces on clasts can be described in many ways, and one classic method is roundness (Krumbein, 1941). Plate 1 of Krumbein (1941) is a set of 10 standard images of clasts with measured roughness values that are used for the visual roundness method of determining roundness, in contrast to using detailed measurements (fig. 8). The original plate 1 was used for pebbles (16-32 mm diameter); however, this image can be enlarged or reduced to represent any particle size, and therefore permit the scale-independent classification (Krumbien, 1941). In figure 8, the two-dimensional profiles nicely show the general geometry of grains as consisting of at least three surfaces that have intersection angles. Visual estimates of roundness (as presented by Krumbein, 1941) are used in some descriptions of clasts in this study; however, this descriptor is not easily applicable to clasts or fragments that include fractured surfaces.

In contrast to Krumbein's scale of roundness for clasts, and using the premise that the surface of a clast originated as a set of fractures, the shape of surfaces on clasts and fractures can be described using the descriptors of shape and roughness. Buesch and others (1996) introduced 
a modified version of the "joint profile and roughness coefficient" of Barton and Choubey (1977) to describe the shape and roughness of fractures in field exposures and small-scale fractures in cores (fig. 9A). As initially applied to fractures, shape was measured in meters (m) and roughness was measured in centimeters $(\mathrm{cm})$. However, the application to fractures in cores revealed an important relation; shape and roughness scales are relative to each other, and the length scale for shape is typically 20-100 times larger than the length scale for roughness. In this study, the modified descriptors have been applied to completely fractured rock fragments, drilling induced fractures on clasts, and the surfaces of clasts (which were originally fractures), so shape and roughness are not necessarily only used for one type of surface.

As originally defined by Buesch and others (1996), both shape and roughness scales were divided into five categories, with shape ranging from planar to very irregular, and roughness from smooth to very rough. Subsequently, a sixth category of shape included very planar and roughness included very smooth, and this six-fold categorization has been adopted in this paper (fig. 9A). The shape and roughness of a fracture surface profile can also be represented on a grain surface profile (fig. 9B). These shape and roughness estimates are used for the surfaces between the intersection angles of the surfaces (see fig. 8). Curviplanar can be substituted for planar where there is a long, broad, arcuate shape to the surface, and this is especially appropriate when shape is applied to a clast. Although shape and roughness are evaluated independently, they tend to covary positively (planar surfaces are typically smooth), but some covary slightly negatively (slightly planar surfaces can be slightly rough to rough), and none covary strongly negatively (planar surfaces are not rough). The shape and roughness scales are not process specific, so in addition to being descriptive, they can be used to infer how effective various processes were

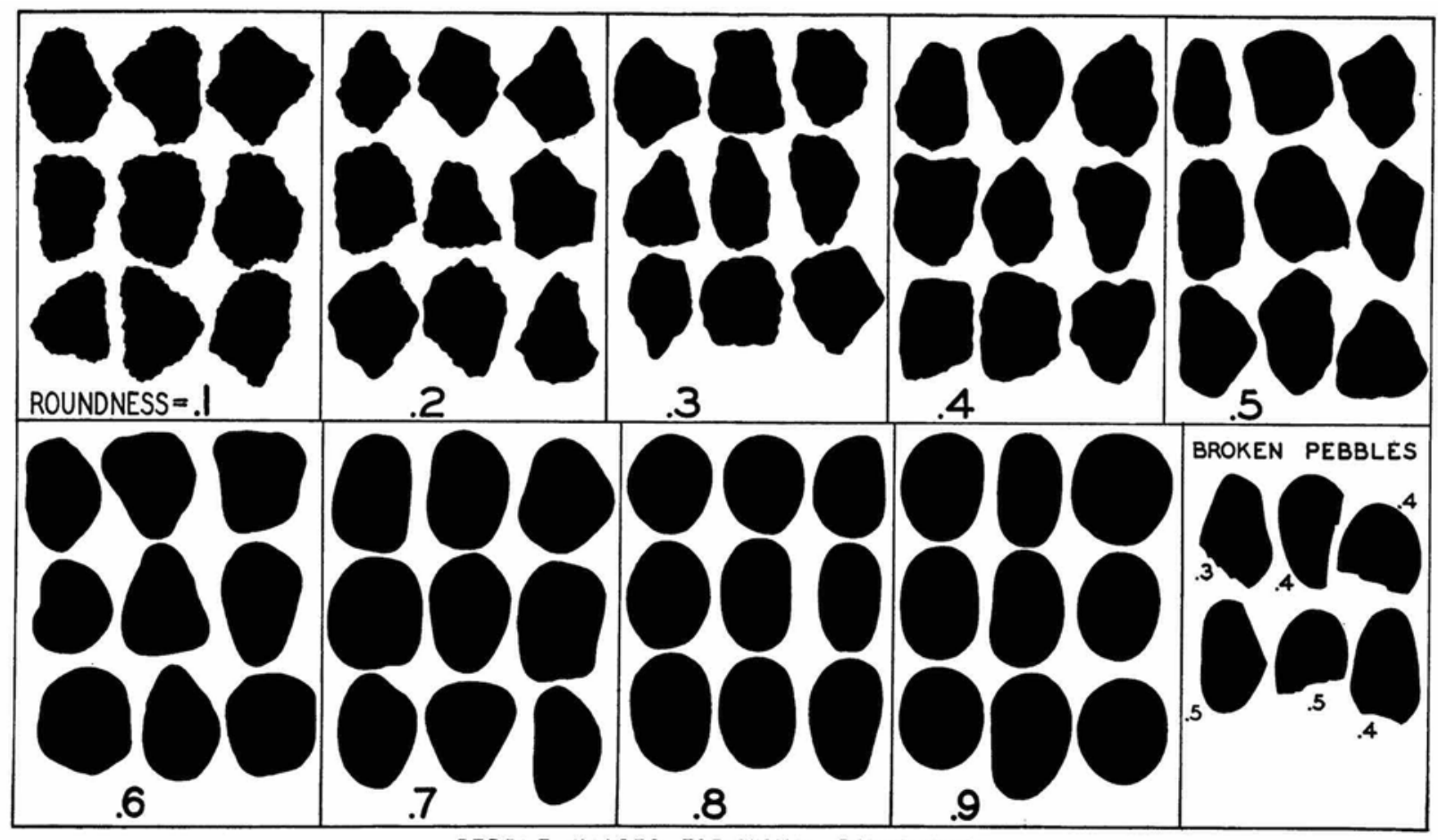

PEBBLE IMAGES FOR VISUAL ROUNDNESS

PLATE 1.-Roundness chart for $16-32 \mathrm{~mm}$. pebbles.

Figure 8. Chart of visual roundness values of clasts (reproduced without modification from Krumbein, 1941). 
A) Shape of fractures Joint profile and roughness coefficient (JRC) Surface roughness

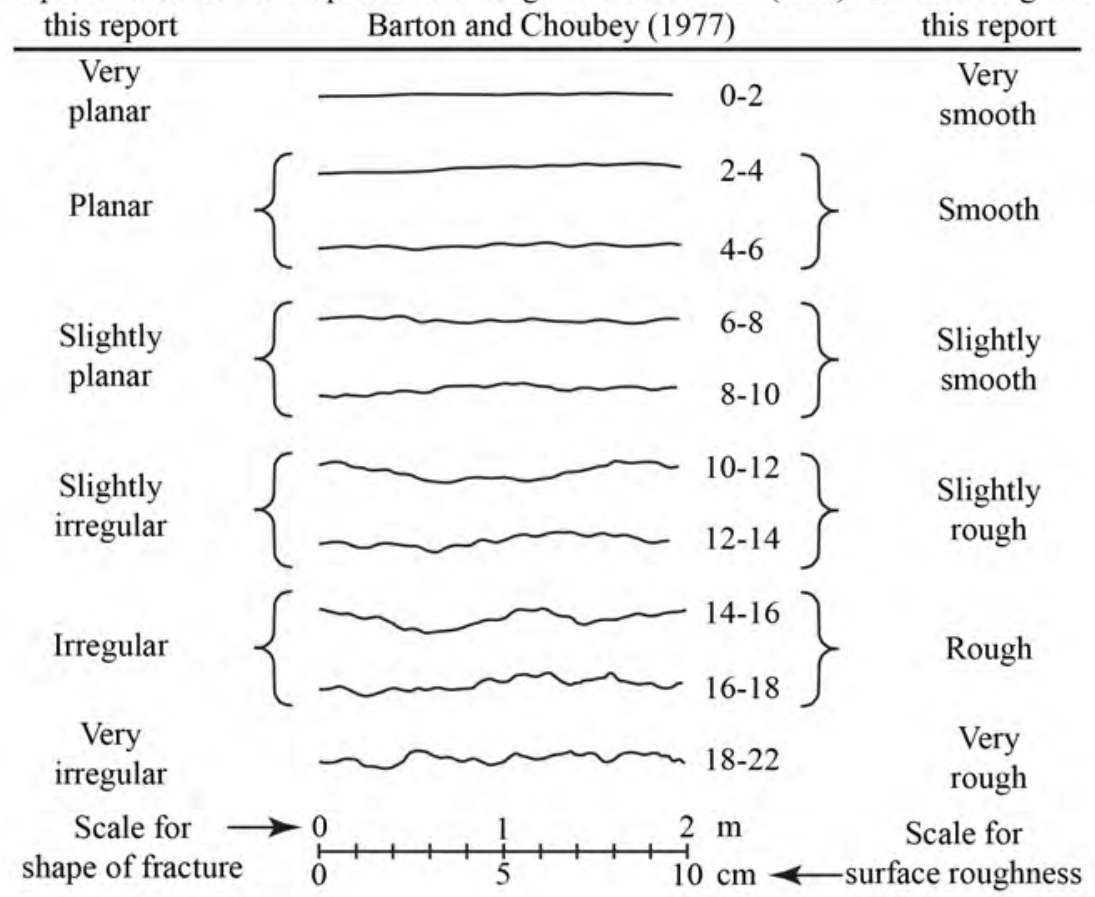

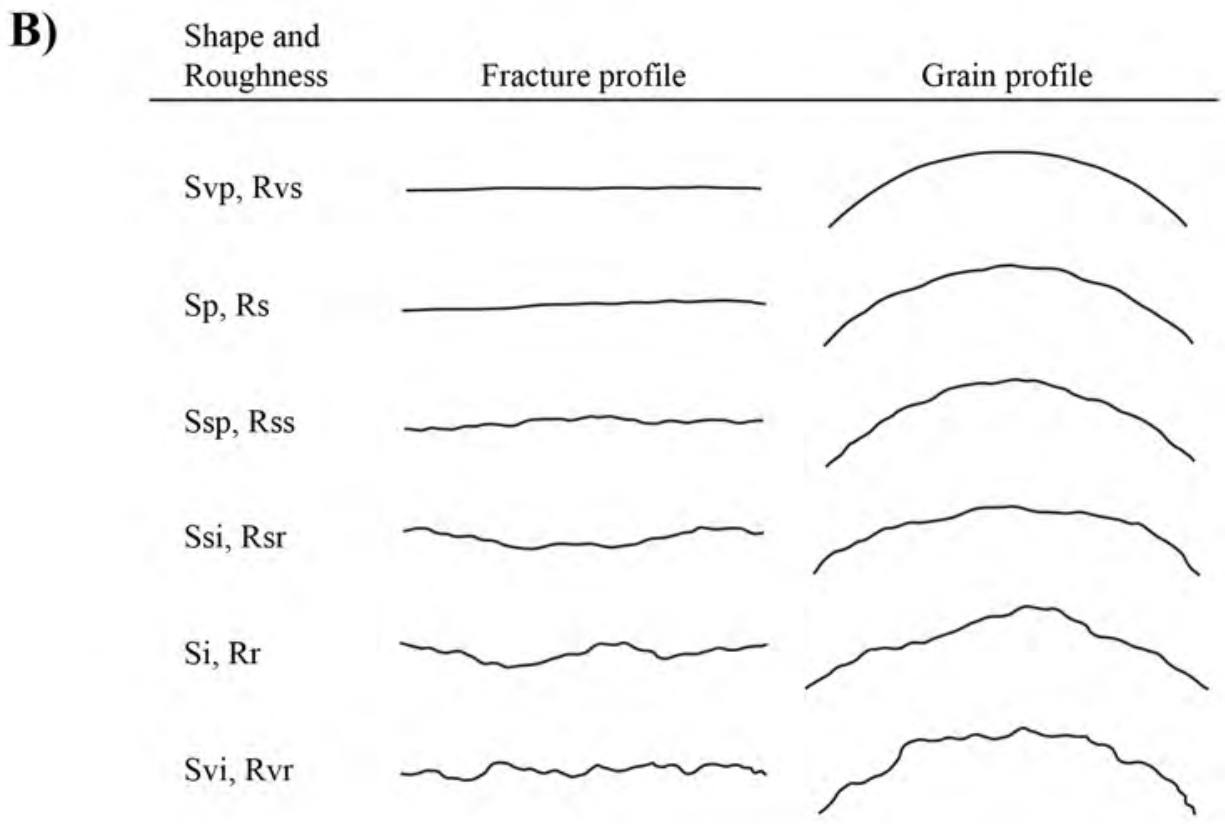

Scales for Shape versus Roughness differ by a factor of $10 \mathrm{x}$ to $100 \mathrm{x}$.

Figure 9. Chart of shape and roughness of fracture and clast surfaces. $A$, joint profile and roughness coefficient, shape, and roughness of fractures (modified from Buesch and others, 1996); B, shape and roughness of fractures and grain profiles. The amount of curvature of the grain profile is for presentation purposes only, and is not an inherent component of the shape. 
during the history of the surface. Two examples: (1) a moderately welded and crystallized ignimbrite can have slightly planar and slightly smooth fractures, but where it has been vaporphase corroded, the fractures can be slightly planar and slightly rough, and (2) if a lava flow clast has freshly broken surfaces (either in the field or during drilling) that are slightly planar and slightly smooth, and the original clast surfaces are planar and smooth, the difference between broken and original surfaces measures the effectiveness of sedimentologic process during transportation and deposition.

Broken and original surfaces of cuttings are used to infer properties of the drilled (or host) rock. Cuttings samples with large amounts of broken fragments and surfaces are interpreted to be the result of fragmenting large amounts of solid rock, for example, a lava flow. Cuttings samples can be pieces of sandstone, and cuttings containing whole or parts of lithic clasts are inferred to be derived from sedimentary host rocks. Furthermore, clasts with mostly original surfaces were probably plucked from the host rock during drilling and disaggregation of the sedimentary rock matrix. Many, well developed, original surfaces are described as rounded to subrounded, relatively smooth, curviplanar or arcuate, and many are "frosted" with a dull sheen when compared to freshly broken surfaces. Lithic clasts or fragments, some as small as $5 \mathrm{~mm}$ and others as large as $22 \mathrm{~mm}$ across, typically have at least one original surface, and this surface can be used to estimate the possible size of the original clast. Based on the shapes of clasts in field exposures where the two- or three-dimensional shapes can be determined, it is assumed that the original clasts were approximately symmetrically shaped, and that the original size can be determined graphically. For an original curviplanar surface, a profile of the surface is drawn, perpendicular lines are constructed from the surface profile to estimate a radius for the sector, and an approximate diameter of the original clast is calculated. This assumption does not hold for clasts with one or more flat sides that imply a very large clast radius. Clast fragments with very small amounts of curvature (basically flat) were not measured because of the large amount of projected radius uncertainty. The largest measured diameter of a clast (or clast fragment) with an original surface was $30 \mathrm{~mm}$, and the largest calculated diameter was $60 \mathrm{~mm}$, although most calculated diameters were less than $30 \mathrm{~mm}$. For context based on the core, the typical diameter of the core was about $60 \mathrm{~mm}$, and in only a few pieces of core were there clasts that had a diameter larger than $60 \mathrm{~mm}$. So, use of the calculated diameter of clasts appears to be consistent with the documented clast sizes from core. Even in samples where the maximum clast diameter was small (such as less than $10 \mathrm{~mm}$ ), the maximum calculated diameter was less than 1.5 to 2.0 times the maximum measured diameter. There is an additional caveat to these maximum clast size estimates. Clast sizes included in borehole cuttings during drilling are biased towards the smaller clasts because not all clasts recovered are included in the cuttings. In some boreholes, there is anecdotal evidence that fragments larger than most cuttings were not collected, nor were the sizes recorded.

Several conditions during drilling affect the characteristics of the cuttings. Drilling through large clasts in conglomerates can result in many broken surfaces and fragments. In some samples, the lithologic variation of the entirely broken fragments is significantly less than the lithologic variation of intact clasts, consistent with the fragmentation of a few large clasts. In many samples, there is a similarity in sizes of the maximum broken and original fragments, and these fragments are hydrologic equivalents that can be lifted out of the borehole by the circulating fluid. The equivalency is based on size and shape of the fragments and clasts, and numerous conditions during drilling such as the viscosity, circulation velocity, and carrying capacity of the drilling mud. However, variations in sizes in different parts of the section 
(especially where interstratified with other parts of the section) are probably indicative of real variations in clast sizes (even though the samples might not be capturing the maximum clast sizes).

All tuffaceous or lithic-rich sedimentary fragments that were identified in the rock type classification have broken edges, and this is consistent with the deposit being broken during drilling. The fact that the sedimentary rock would break rather than disaggregate during drilling is an indicator of the relative strength of the rock. These broken surfaces on what were partially lithified tuff or sandstone, or possibly the matrix of a conglomerate or breccia, were not included in the estimates of broken versus original surfaces on lithic clasts. Where the matrix, and especially the grain-size, of the sedimentary rock can be identified, the broken surfaces are indicators of clasts that typically are larger than those in the supporting matrix. Some samples have tuffaceous or lithic-rich sedimentary fragments that are partially rounded, and where these are associated with angular fragments of the same rock, then this rounding probably occurred during drilling.

\section{Interpretation of Componentry Data}

The componentry data can be used to infer lithologic characteristics of the drilled host rock using the guiding principles listed below. The componentry data included in the graphs for the individual samples in boreholes are summarized in table 2.1.

- Cuttings samples that have a dominant lithology (for example, pre-Tertiary bedrock, olivine basalt, ignimbrite, or siltstone) are inferred to be sampled from a host rock of that lithology. Cuttings samples that have no dominant lithology are inferred to be sampling a sedimentary host rock with clasts that would produce cuttings of diverse lithology, such as a conglomeratic sandstone or conglomerate.

- The volumetric amounts of broken fragments in the cuttings samples represent the minimum volumetric amounts of fragments in the host rock large enough to break during drilling.

- If the cuttings contain greater than 90 percent broken surfaces and all fragments have the same rock type composition, then the drilled rock is probably a lava flow or monomictic breccia.

- The volumetric amounts of original clasts indicate the volumetric amounts of clasts in the matrix of the drilled rock.

- The fragments with a large percentage of original surfaces are from relatively small (pebble, granule, or sand) clasts in the matrix of a sandstone or conglomerate.

- If the cuttings contain no tuffaceous or lithic-rich sedimentary fragments, but are almost entirely lithic clasts with original clast surfaces that are less than $8 \mathrm{~mm}$ in diameter, then the drilled rock is a poorly lithified, fine-grained pebbly sandstone.

- If there is a wide variety of lithic clasts, and there are appreciable amounts of broken and original fragments, then the percentage of broken fragments is probably proportional to abundance of large lithic clasts. For example, with 25 percent broken fragments and less than $6 \mathrm{~mm}$ original clasts, the host rock might be a pebbly to cobbly sandstone; however, if there are 60 percent broken fragments, then it is probably a cobbly to bouldery conglomerate with a sandstone matrix. These broken to original surface ratios can be pushed a little farther to empirical generalizations that (1) samples with greater than 40 percent broken fragments are probably more conglomeratic, larger grained, and lithic-rich with less sandy (and possibly tuffaceous) matrix compared to (2) samples with less than 
40 percent broken fragments that probably have fewer clasts with large grain sizes, relatively more (and possibly tuffaceous) matrix, and probably represent pebbly to cobbly sandstones, and (3) samples with less than 0-10 percent broken surfaces probably represent fine pebbly sandstone, sandstone, siltstone, or mudstone.

\section{Borehole Geophysical Log Data and Stratigraphy}

The borehole geophysical log data provide an important continuous dataset that represents the lithostratigraphy in the borehole walls. For geophysical log data at Fort Irwin that are described in this report, the lines connecting the point data on graphic displays are described with terminology borrowed from wave forms. "Trough" is the locally lowest value, "peak" is the locally highest value, "wavelength" is the distance along the borehole from crest to crest (or similar parts of the waveform), "amplitude" is the difference in values between an adjacent peak and trough, and "cycles" consist of a series of similarly shaped peak-and-trough waveforms (fig. 10). Cycles can have waveforms with constant, increasing, or decreasing wavelength and (or) amplitude, and the mean values for the waveforms in a cycle can be constant, increase, or decrease. Comparisons of the trends in cycles between different types of data can covary positively, neutrally, or negatively. Figure 10 has a number of labeled cycles and correlations for the purposes of showing what these geophysical features look like. Most of the geophysical log data in this report will have salient parts of the data described and selectively labeled on the figures, but the figures will not be labeled in such detail.

Each geophysical log responds differently to the changes in rocks in the borehole walls, and this is based on (1) what is being measured (radionuclides, resistivity, or acoustic properties), (2) differences in the distance between sensors along the borehole for each instrument, (3) the contrast in properties between adjacent rocks, and (4) bed thickness (Keys and MacCary, 1971). The simplest configuration of sensors and thickness of a bed results in a simple waveform from trough to peak to trough. In a simple waveform, the bedding contact is typically somewhere along the slope from trough to peak (that is, it is rarely at the trough or peak); however, where the contact is located results from the contrast in properties in the adjacent beds. As properties and thickness of the bed change relative to the sensors, the waveform can have smaller multiples in amplitude and wavelength or become complex. These variations in how instruments sense changes in rock properties on either side of a contact is one reason why some waveforms in the data are complicated. Another reason for the complexity is that there are differences in properties of thin beds that the sensors respond to. In summary, not every waveform represents a feature such as a bed or bedset, and a bed or bedset might be represented by some complicated waveforms, but a series of similar waveforms in a cycle probably represents a series of beds or bedsets. At Fort Irwin, there are very little corroborating data (such as limited core and no borehole video logs) that can help resolve the source of variation in the data and waveform morphology. 


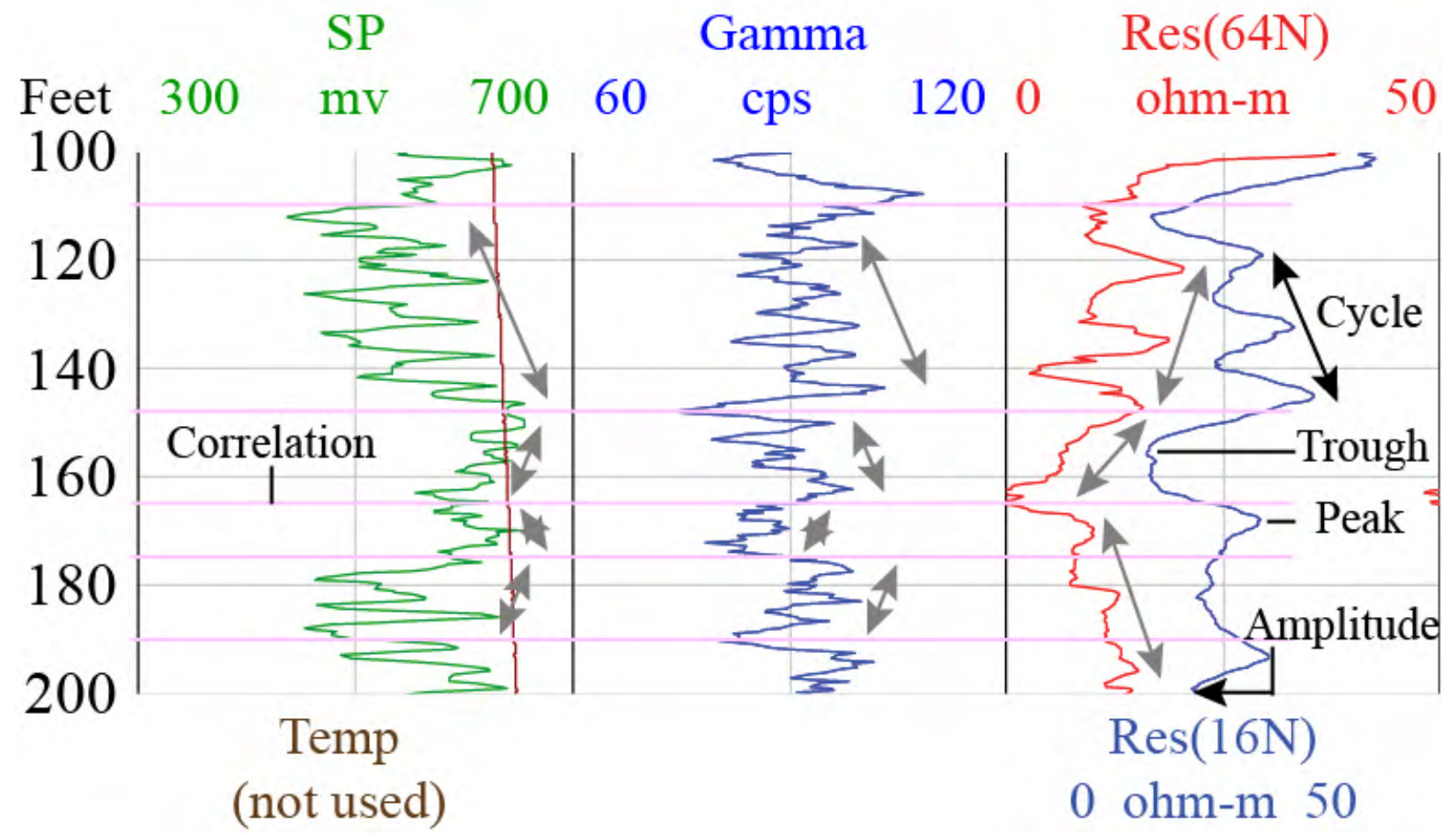

Figure 10. Chart showing waveform nomenclature and correlations of borehole geophysical log data. Data extracted from borehole NELT3 at Fort Irwin, north-central Mojave Desert, California. SP, spontaneous potential; mv, millivolts; Gamma, gamma ray; cps, counts per second; Res, resistivity (64N, 64 inch normal; $16 \mathrm{~N}, 16$ inch normal); ohm-m, ohm-meter.

As with the complications of inferring individual beds with a geophysical log waveform, individual waveforms or cycles in one dataset (including the tops and bottoms) might closely resemble those of other datasets, but they do not necessarily correlate (fig. 10). The correlations in figure 10 were based on changes in the morphology of the waveforms and (or) cycles in one or more geophysical logs. For example, at a depth of $108 \mathrm{ft}$ in borehole NELT3, the spontaneous potential, gamma-ray, and resistivity data all have a change in waveform morphology (fig. 10). These correlations are not necessarily unique, and there could be any number of other correlations that might correlate the properties of the rocks differently. For example, at a depth of $174 \mathrm{ft}$ a correlation was made, but a different set of relations would be made at $180 \mathrm{ft}$. How well the different types of data are correlated depends on the type of data collected and the properties of the rocks. The goal of the analyses supporting this paper has not been to develop bed by bed correlations of lithostratigraphy and geophysical log data, but to document variations in the virtual geophysical log stratigraphy that appear to reflect potential differences in lithostratigraphy.

In addition to lithostratigraphic properties, resistivity logs provide important insights into the hydrogeologic properties, especially in the unsaturated zone. Intensive geologic and hydrogeologic studies elsewhere, including surface-based and borehole-based measurements, have shown strong correlations of lithologic and hydrogeologic properties in sedimentary and volcanic rocks to infiltration and transport of water through the unsaturated zone, and to transport and storage of water in the saturated zone (Flint and others, 2001; Flint and others, 2002; Flint and others, 2006). During infiltration, surface water percolates through the soil and is held in the near surface in the root zone where it is removed by evapotranspiration (Flint and 
others, 2001). Water that percolates deeper than the root zone begins to move downward toward the saturated zone. However, depending on increase and decrease in barometric pressure, dry atmospheric air can enter the unsaturated zone, evaporate the moisture, and the moist air leaves the ground during periods of barometric pressure decline (Flint and others, 2002). The combination of evapotranspiration and barometric pumping and evaporation results in large gradients from dry near-surface conditions to moist unsaturated conditions near the water table and saturated zone. The borehole resistivity logs at Fort Irwin show this large gradient in moisture, and rather than a smooth transition from the top to bottom of the unsaturated zone (dry and high resistivity, and moist and low resistivity, respectively), the steps, reversals, and gradients in the apparent moisture are indicators of the hydrologic properties of the lithostratigraphy.

\section{Lithostratigraphy in Borehole GOLD1}

Borehole GOLD1 is located on the valley floor east of Goldstone Lake, north of Goldstone Mesa, northwest of Stone Ridge, and southwest of the Pioneer Plateau (fig. 2). The highlands surrounding the valley consist of Miocene lava flows, pyroclastic deposits, and clastic sedimentary deposits. Lava flows in the area include porphyritic olivine basalts, sparsely porphyritic basalts, basaltic andesite, andesite, dacite, and rhyolite. Several faults, including the Goldstone Lake Fault, have been mapped in the area.

Borehole GOLD1 was drilled as a single borehole, and was developed as three individual wells that sampled different depths (table 1). Borehole GOLD1 was drilled using rotary drilling techniques and cuttings samples were collected from the shaker table in 10-ft intervals, and three core samples were collected at 200-203 ft, 500-503 ft, and 680-684 ft with 36, 36, and 37 percent core recovery, respectively (Kojs and others, 2014; figs. 11, 12). Twenty cuttings intervals were sampled for detailed examination (fig. 12). Samples for detailed examination were identified based on several criteria: (1) identification of specific rock types associated with changes in geophysical log data (for example, from $294 \mathrm{ft}$ to $418 \mathrm{ft}$, and from $600 \mathrm{ft}$ to $680 \mathrm{ft}$ ), (2) samples from the screen intervals of wells (labeled as sand pack in fig. 12), (3) samples from above and below the water table, and (4) samples from different parts of the sedimentary section to identify features that might indicate or constrain the ages of the deposits. The components in cuttings samples, including the type of rock fragments, the amount of broken and original surfaces on lithic clasts, and features such as rims, rinds, and coatings are displayed in figure 13. The intention was to distinguish the Miocene volcanic section from the Quaternary(?) or Pliocene(?) sections.

\section{Interpretations for Lithostratigraphy in GOLD1}

The stratigraphy of borehole GOLD1 includes young (probably Quaternary to Pliocene?) alluvial sandstones and gravels and older (Miocene?) mostly tuffaceous deposits and lava flows. Five lithofacies are identified; three of which include tuffaceous sedimentary rocks, pyroclastic flow deposits (or ignimbrites), and lithic-rich sedimentary rocks, and two of which include monolithic deposits formed from lava flows or avalanche-sedimentary breccia. Lithic-rich sedimentary deposits are characteristic of the younger (Quaternary to Pliocene?) alluvial gravels; however, they also occur intermittently in the older (Miocene?) section. 
A

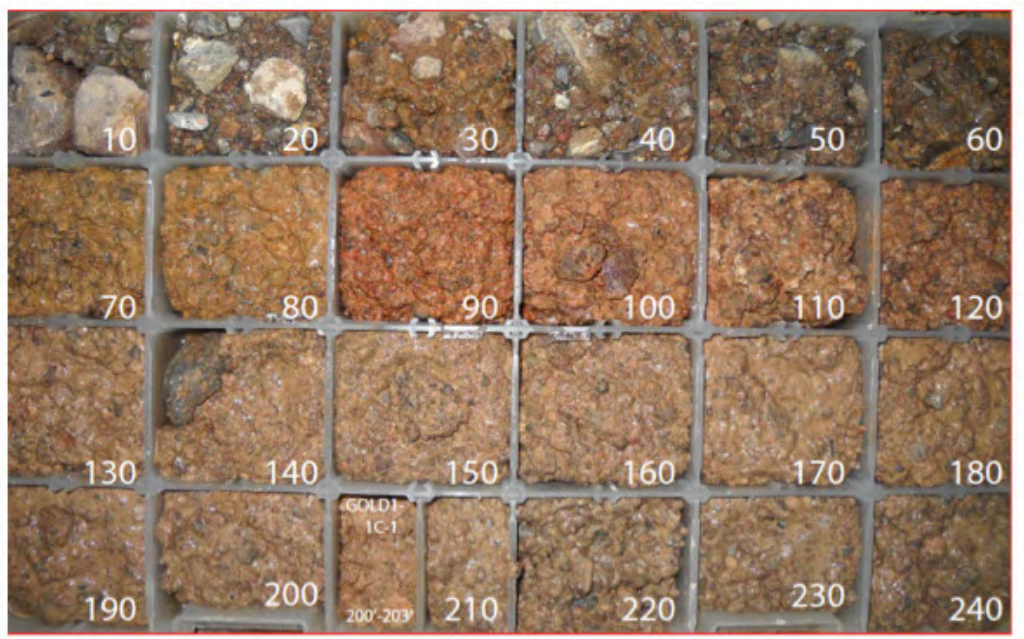

B

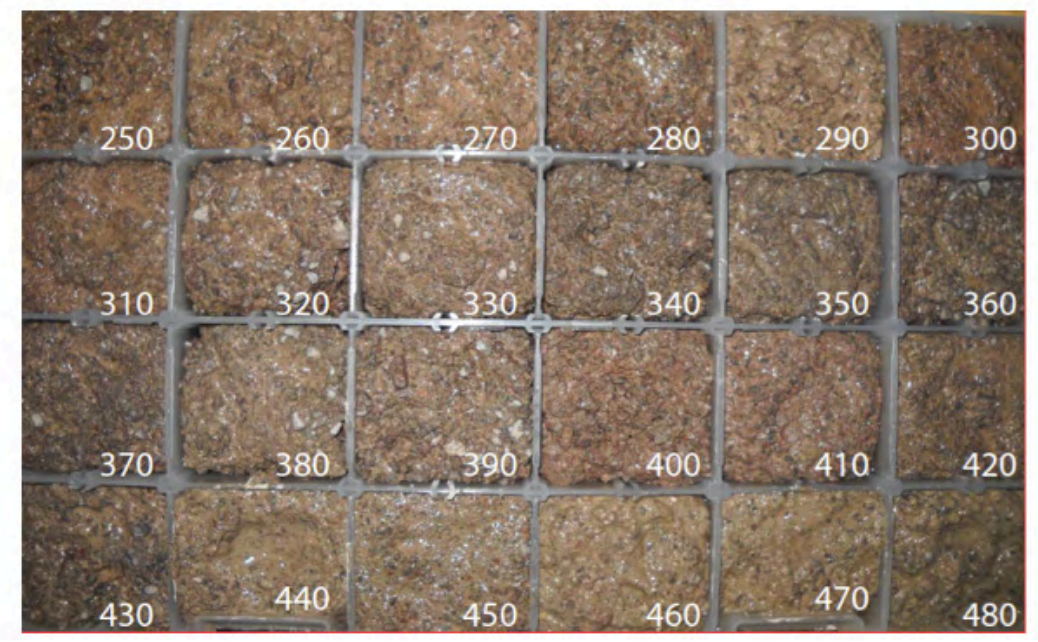

C

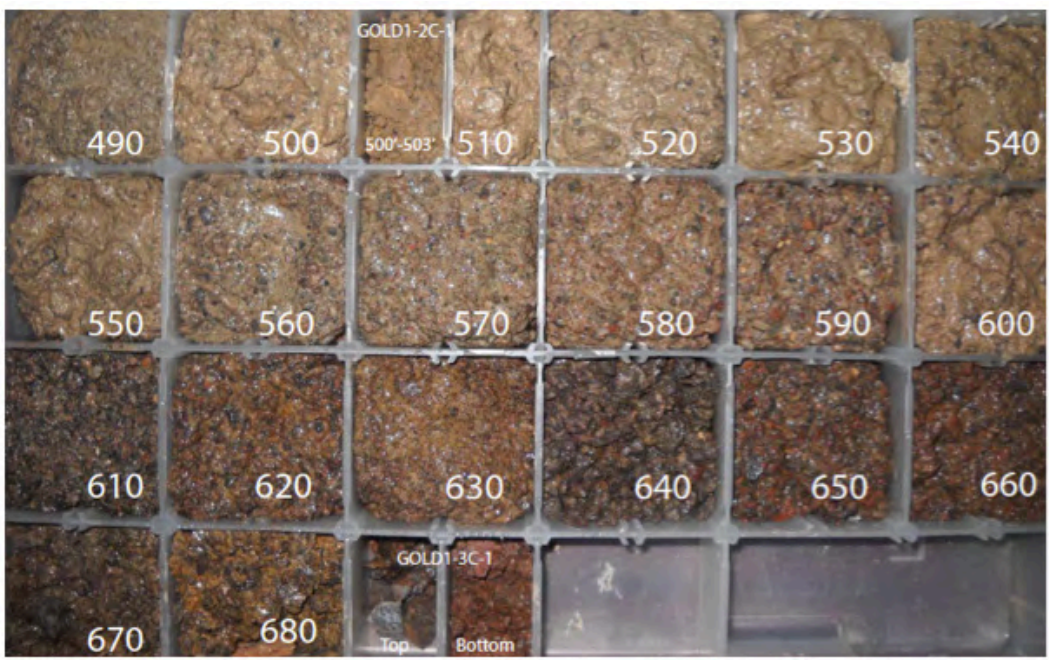

Figure 11. Photographs of cuttings from the shaker table for borehole GOLD1 at Fort Irwin, California. A, samples from 10 to 240 feet (ft); $B$, samples from 250 to $480 \mathrm{ft} ; C$, samples from 490 to $680 \mathrm{ft}$. Core samples at 203,503, and $684 \mathrm{ft}$. A square chip cell is 50×55 millimeters. U.S. Geological Survey photographs by Joseph Nawikas. 


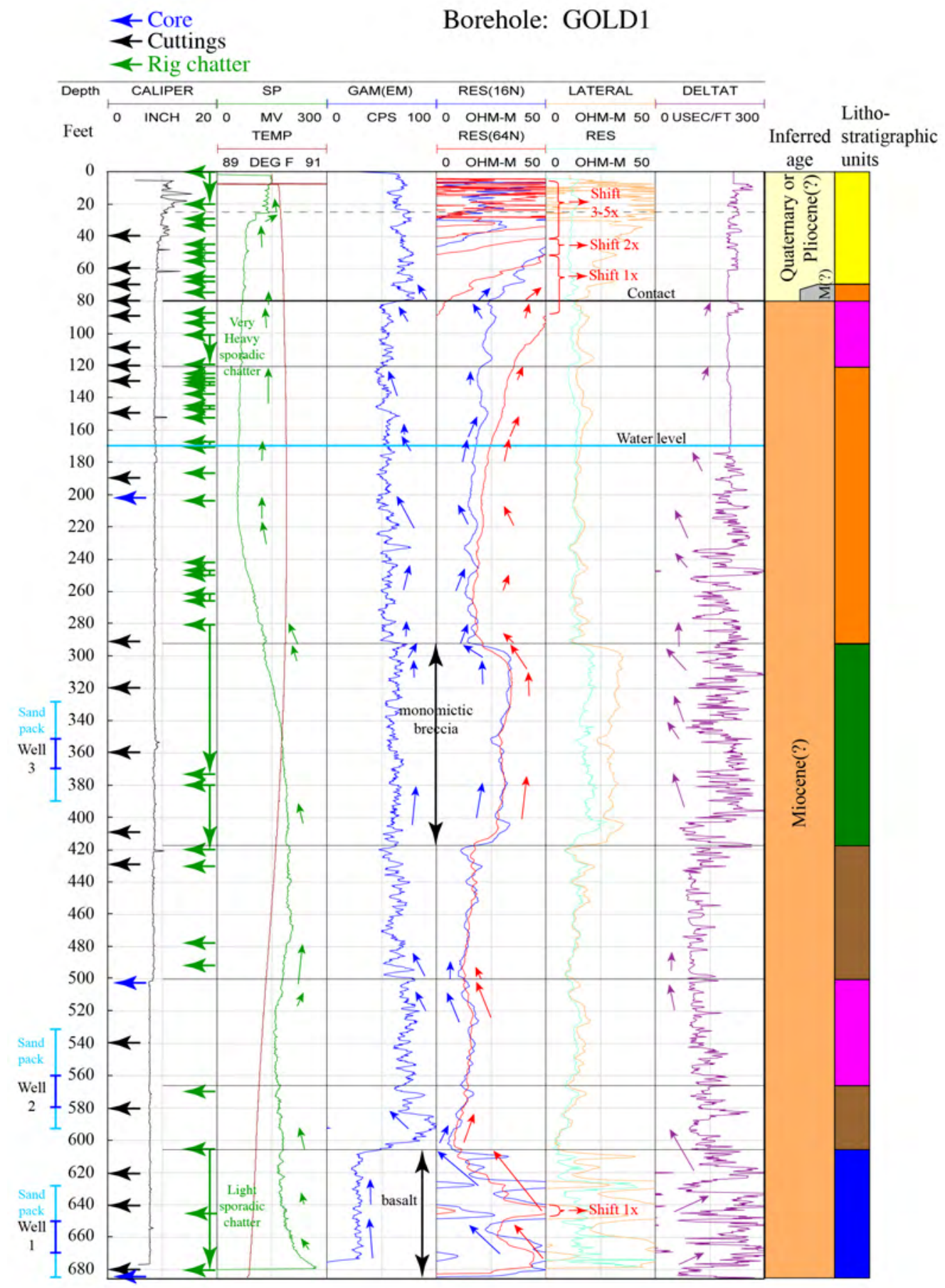

Figure 12. Graph showing locations of cuttings samples in borehole GOLD1 at Fort Irwin, California, used for detailed examination compared to core, borehole geophysical logs, rig chatter, and locations of screened intervals 1, 2, and 3. Rig chatter from Joseph Nawakis (USGS, written commun., 2011). Borehole geophysical logs and depths to screened intervals from Kojs and others (2014). Lithostratigraphic units: yellow, detrital (volcanic-lithic) sandstone and conglomerate; orange, lithic to lithic-rich sedimentary rocks with tuffaceous ( \pm pumiceous) matrix; magenta, tuffaceous sandstone with ignimbrite; green, dacitic lava or monomictic avalanche breccia; brown, volcanic-lithic sandstone with tuffaceous-pumiceous(?) matrix; and blue, olivine basalt flows. 


\section{Young (Quaternary to Pliocene?) Alluvial Gravels (0-70 ft) in GOLD1}

Young (Quaternary to Pliocene?) alluvial gravels and sands (or poorly to partially lithified conglomerates and sandstones) were penetrated at depths of $0-70 \mathrm{ft}$. Shapes of the cuttings fragments indicate that most fragments less than $10 \mathrm{~mm}$ in size have one or more original clast surfaces. The size of parent clasts, from which clast fragments were derived, have estimated diameters of 15-30 mm (using the method described in section Original Clasts and Broken Fragments). Some original clast surfaces are nearly flat, planar, and smooth, and for these clasts the original diameter was not estimated. The amount of lithic-rich sedimentary matrix attached to lithic clasts as coatings indicates that partially lithified lithic-rich sand comprises the matrix of the gravel and conglomerate beds. Minor amounts of tuffaceous sediment attached to lithic clasts as coatings are consistent with the clasts having been derived from the disaggregation of tuffaceous sedimentary rocks. However, the coatings do not appear abraded or rounded, so it is possible that some beds have a matrix composed of tuffaceous sediment. The occurrence of rinds on some fragments is consistent with the local formation of carbonate pedogenic deposits, and there was no indication that the fragments with rinds were eroded and transported after the rinds were formed.

\section{Detailed Observations on the Young (Quaternary to Pliocene?) Alluvial Gravels and Sands}

- During the gentle washing of cuttings samples, the samples from 40 to $70 \mathrm{ft}$ had slightly turbid water that cleared within several minutes, and the samples from $80 \mathrm{ft}$ and deeper had turbid water that took tens of minutes to clear. The turbidity and time to clear it were probably indicators of the amounts of fines from the wall rocks that were mixed into the drilling mud.

- Bulk cuttings samples from the shaker table from 0 to $60 \mathrm{ft}$ are reddish brown to light reddish brown (these are from wet samples) (fig. 11). The colors are based on the Munsell Soil Color Chart (GretagMacbeth, 2000); however, they are simplified, so specific Munsell values are not used (and this is also the case for the descriptions below).

- Rig chatter occurred every 3-10 ft from 0 to $67 \mathrm{ft}$ and once at $75 \mathrm{ft}$ (fig. 12). This spacing of rig chatter is consistent with drilling through interbeds of coarse-grained gravel (or conglomerates), which cause the rig to chatter, and sands (or sandstones) that are drilled with no chatter.

- $\quad$ The detailed component data for shaker cuttings samples are summarized in figure 13.

- The shaker cuttings sample at $40 \mathrm{ft}$ has olivine basalt (10 percent), a range of fragments from andesite to rhyolite (60 percent), minor amounts of tuffaceous sediment fragments (5 percent), and lithic-rich sediment fragments (20 percent). The amount of broken fragments is consistent with the fracturing of clasts during drilling, and most fragments less than $10 \mathrm{~mm}$ have one or more original surfaces. Several fragments have rinds. No fragments have tuffaceous matrix coating; however, 25 percent have lithic-rich matrix coatings.

- The shaker cuttings sample at $60 \mathrm{ft}$ has no olivine basalt nor lithic-rich sedimentary fragments, but it does have a range of fragments from andesite to rhyolite (97 percent), and a minor amount of tuffaceous sediment fragments (3 percent). There are slightly fewer broken fragments, with most fragments less than $10 \mathrm{~mm}$ having one or more original surfaces, and this is consistent with more plucking of grains from the host rock 
than fracturing of clasts during drilling. Several fragments have rinds. Only a few fragments have tuffaceous matrix coating; 22 percent have lithic-rich matrix coatings.

- Borehole geophysical log values differ at depths shallower than 70-80 ft compared to those deeper than 80-90 ft (fig. 12). There is a sharp decrease in gamma-ray values at 25 $\mathrm{ft}$, and the values are slightly larger at depths from 25 to $80 \mathrm{ft}$ compared to depths from 80 to $150 \mathrm{ft}$. Resistivity values at depths shallower than $70 \mathrm{ft}$ are large, values from 70 to $90 \mathrm{ft}$ are transitional, and values at depths from 90 to $120 \mathrm{ft}$ are smaller. Although the sonic log values have less sensitivity in the unsaturated zone compared to the saturated zone, there are small-scale variations in values from 10 to $60 \mathrm{ft}$, minimal variation from 60 to $80 \mathrm{ft}$, and increased variation from 80 to $90 \mathrm{ft}$, and minimal variations from 90 to $173 \mathrm{ft}$ (the water table).

The contact of the younger (Quaternary to Pliocene?) alluvial gravels and sands and the tuffaceous (Miocene?) sediments is interpreted to be at the sharp color change between the shaker table sample at $60 \mathrm{ft}$ and the two samples at 70 and $80 \mathrm{ft}$. As described below, the sample at $80 \mathrm{ft}$ shares many characteristics with the deeper part of the section (including abundant tuffaceous sedimentary fragments and tuffaceous coatings on lithic clasts). However, the sample at $70 \mathrm{ft}$ is more problematic in that there are not distinctive changes at $70 \mathrm{ft}$ for lithostratigraphic components and geophysical log data. The sample appears to contain a mixture of materials from above and below a contact of different types of sedimentary rocks. The sampled interval probably includes the contact with components of both the younger (Quaternary to Pliocene?) sediments and the older (Miocene?) sediments mixed together, possibly during (1) surficial transport near the time of deposition, (2) near-surface processes of bioturbation, translocation of grains, or (3) up-hole contamination of the younger material into the cuttings. The poor recovery of cuttings near the depths of 70-75 ft probably increased the relative amount of mixing with (or contamination by) fragments from less than $70 \mathrm{ft}$ depths. The lack of rig chatter from 68 to $75 \mathrm{ft}$ is consistent with a contact that is within an interval of easily drilled rocks. The interpretation is that the sample interval spans the lithostratigraphic contact at $70 \mathrm{ft}$.

\section{Miocene(?) Tuffaceous Sediments and Lava Flows (70-684 ft) in GOLD1}

Borehole GOLD1 penetrates the Miocene volcanic section from 70 to $684 \mathrm{ft}$ (the total depth of the borehole). The volcanic section consists of four subunits (fig. 12) and from top to bottom they are (1) predominately tuffaceous sedimentary deposits from 70 to $294 \mathrm{ft}$, (2) either a lava flow or monomictic avalanche deposit from 294 to $418 \mathrm{ft}$, (3) predominately tuffaceous sedimentary deposits from 418 to $605 \mathrm{ft}$, and (4) olivine basalt lava flows from 605 to $684 \mathrm{ft}$. There are several intervals in the tuffaceous deposits with interstratified lithic-rich sedimentary deposits.

Miocene(?) Tuffaceous Sediments (70-294 ft) in GOLD1

Miocene tuffaceous sediments from 70 to $294 \mathrm{ft}$ consist of primary and redeposited tuffaceous deposits that contain various amounts of lithic clasts. It is likely that some of the tuffaceous deposits were emplaced by pyroclastic flows, and possibly fallout tephra. Some intervals are lithic-rich sedimentary deposits that probably represent a more alluvial or fluvial depositional environment within the volcanic field. 
Detailed Observations on the Deposits at 70 and $80 \mathrm{ft}$

- The bulk cuttings samples at 70 and $80 \mathrm{ft}$ are pink to yellow, and different in color from samples above and below (fig. 11). If the samples at 70 and $80 \mathrm{ft}$ are just barely at the top and bottom of a deposit respectively, then the deposit would only be $10 \mathrm{ft}$ thick.

- The drill-site rig lithologic log indicates that from 70 to $75 \mathrm{ft}$ there were fewer and finergrained cuttings compared to the intervals above and below these depths. The finer grained cuttings might not be represented as well as coarser grained cuttings in that the finer grained material would pass through the sample sieve. Also, the diminished amount of cuttings might skew the sample of the drilled (host) rock and make the amounts of host-rock fragments more susceptible to contamination from fragments plucked from the walls during the flow of cuttings and drilling fluid to the surface. Rig chatter occurred every 3-10 ft from 0 to $67 \mathrm{ft}$, once at $75 \mathrm{ft}$, and began again at 89 and $94 \mathrm{ft}$ with "very heavy, sporadic chatter" from 101 to $120 \mathrm{ft}$ (fig. 12).

- Several components identified during detailed analysis of the shaker-table cuttings indicate a similarity to the younger sediments (fig. 13). There are numerous olivine basalt fragments in the sample from $40 \mathrm{ft}$, none in the sample from $60 \mathrm{ft}$, only one fragment at $70 \mathrm{ft}$, and there are no olivine basalt fragments from 80 to $600 \mathrm{ft}$. It is possible that the one olivine basalt fragment in the sample from $70 \mathrm{ft}$ is sample contamination and was plucked from the wall rock during return of the cuttings to the surface. There are only minor amounts of tuffaceous and lithic-rich sedimentary fragments at $70 \mathrm{ft}$, which is similar to the sample at $60 \mathrm{ft}$; however, there are numerous tuffaceous and lithic-rich sedimentary fragments at $40 \mathrm{ft}$. The minimal amounts of sedimentary fragments at 60 and $70 \mathrm{ft}$ might result from the small amount of matrix in the deposits, or disaggregation of the sedimentary matrix during drilling or sample handling. In contrast, samples from $80 \mathrm{ft}$ and deeper have appreciable amounts (40 percent) of tuffaceous sedimentary fragments. All three samples from 40, 60, and $70 \mathrm{ft}$ have lithic-rich sedimentary coatings on lithic clasts. In contrast, samples from $80 \mathrm{ft}$ and deeper have appreciable amounts of tuffaceous sedimentary coatings.

- Borehole geophysical log values differ at depths less than 70-80 ft compared to those deeper than 80-90 ft; however, not all geophysical log values change at the same depth (fig. 12). Gamma-ray values are slightly larger at depths from 0 to $80 \mathrm{ft}$ compared to depths from 80 to $150 \mathrm{ft}$. Resistivity values at depths from 70 to $90 \mathrm{ft}$ are transitional to those shallower than $70 \mathrm{ft}$ and from 90 to $120 \mathrm{ft}$. Spontaneous potential values are slightly larger at depths from 30 to $80 \mathrm{ft}$ compared to depths from 80 to $220 \mathrm{ft}$. Although the sonic $\log$ values have less sensitivity in the unsaturated zone compared to the saturated zone, there are small-scale variations in values from 10 to $60 \mathrm{ft}$, minimal variation from 60 to $80 \mathrm{ft}$, and increase from 80 to $90 \mathrm{ft}$, and smaller values and minimal variations from 90 to $173 \mathrm{ft}$ (the water table).

The remainder of the tuffaceous sediments from 82 to $294 \mathrm{ft}$ consists primarily of tuffaceous sedimentary rocks, including a possible ignimbrite from 82 to $120 \mathrm{ft}$ and several slightly more lithic-rich beds. The ignimbrite was identified in the cuttings; however, the top and bottom of the deposit were primarily identified on the gamma-ray and resistivity geophysical logs where these data have distinct changes in waveforms compared to the rocks above and below. Color changes of the bulk shaker samples, examination of cuttings fragments, and interpretations of geophysical logs indicate that many of the sedimentary beds are a few feet to tens of feet thick, and bedsets are from 10 to $80 \mathrm{ft}$ thick. Cuttings near the top of the section 
Probably Quaternary to Pliocene(?)

Lithic rich, alluvial fan, conglomerate and sandstone
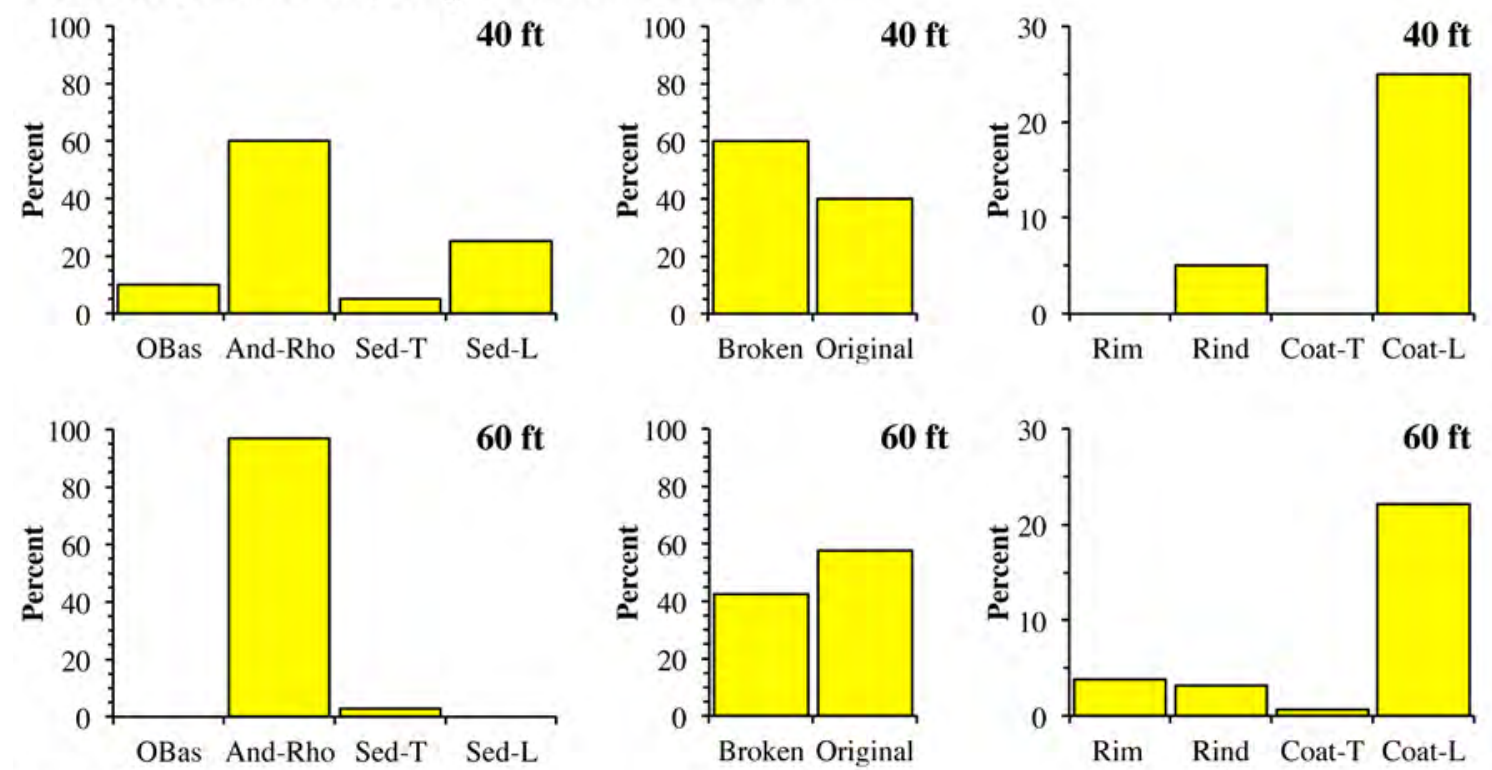

Probably Miocene(?)

Tuffaceous sedimentary rocks (tuffaceous and minor lithic-rich sandstone)
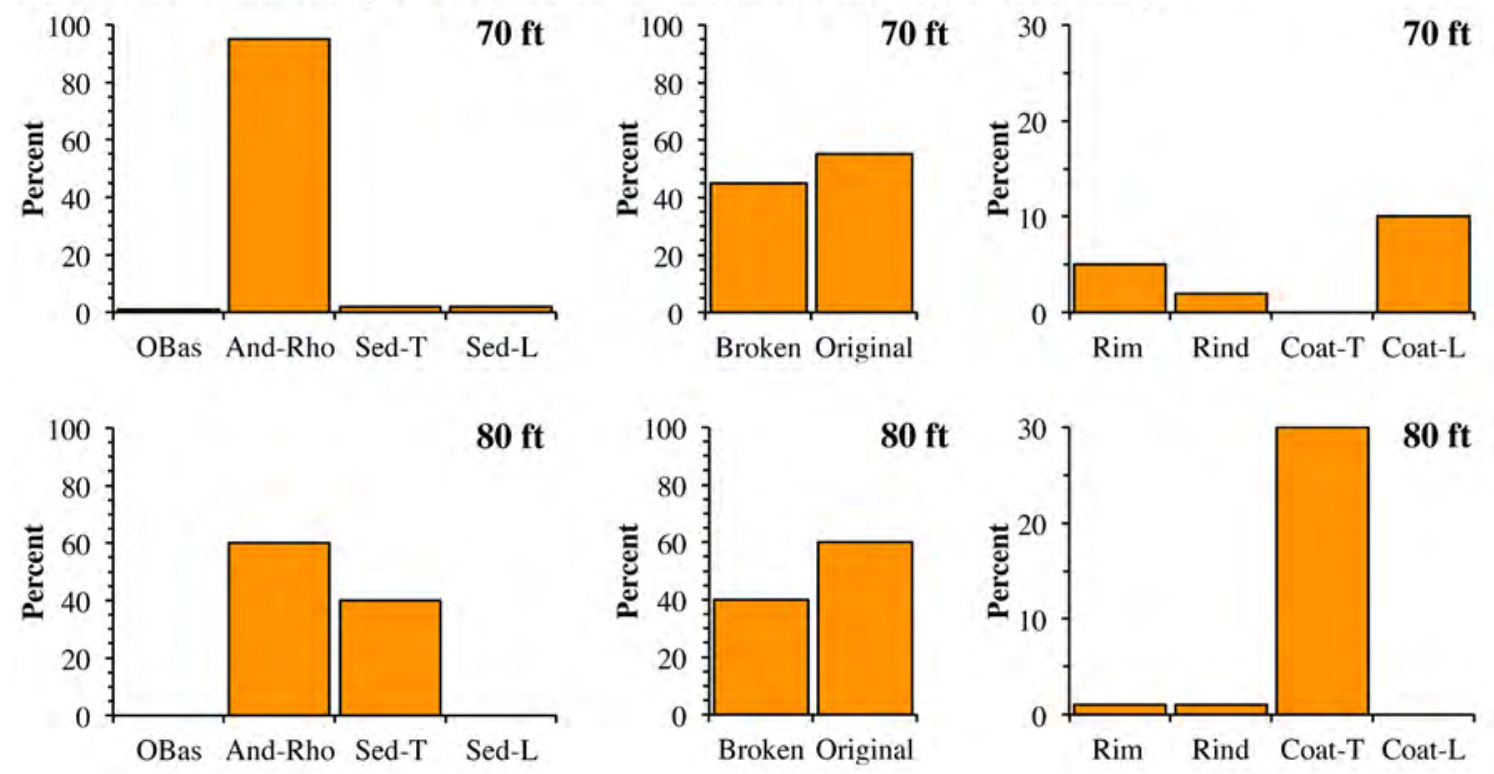

Figure 13. Bar graphs of components of cuttings samples in borehole GOLD1 at Fort Irwin, California. Lithostratigraphic units: yellow, detrital (volcanic-lithic) sandstone and conglomerate; orange, lithic to lithicrich sedimentary rocks with tuffaceous ( \pm pumiceous) matrix; magenta, tuffaceous sandstone with ignimbrite; green, dacitic lava or monomictic avalanche breccia; brown, volcanic-lithic sandstone with tuffaceous-pumiceous(?) matrix; blue, olivine basalt flows. Components: Obas, porphyritic olivine basalt; And-Rho, andesite to rhyolite; Sed-T, tuffaceous sedimentary rocks, Sed-L, lithic-rich sedimentary rocks; Broken, broken surfaces; Original, original surfaces; Rim, thin layer of crystallization in volcanic rock along a cooling fracture; rind, calcite, opal, or chalcedony deposits on a lithic clast; Coat-T, tuffaceous coatings; Coat-L, lithic-rich coatings. 
Possibly pyroclastic deposit (ignimbrite)
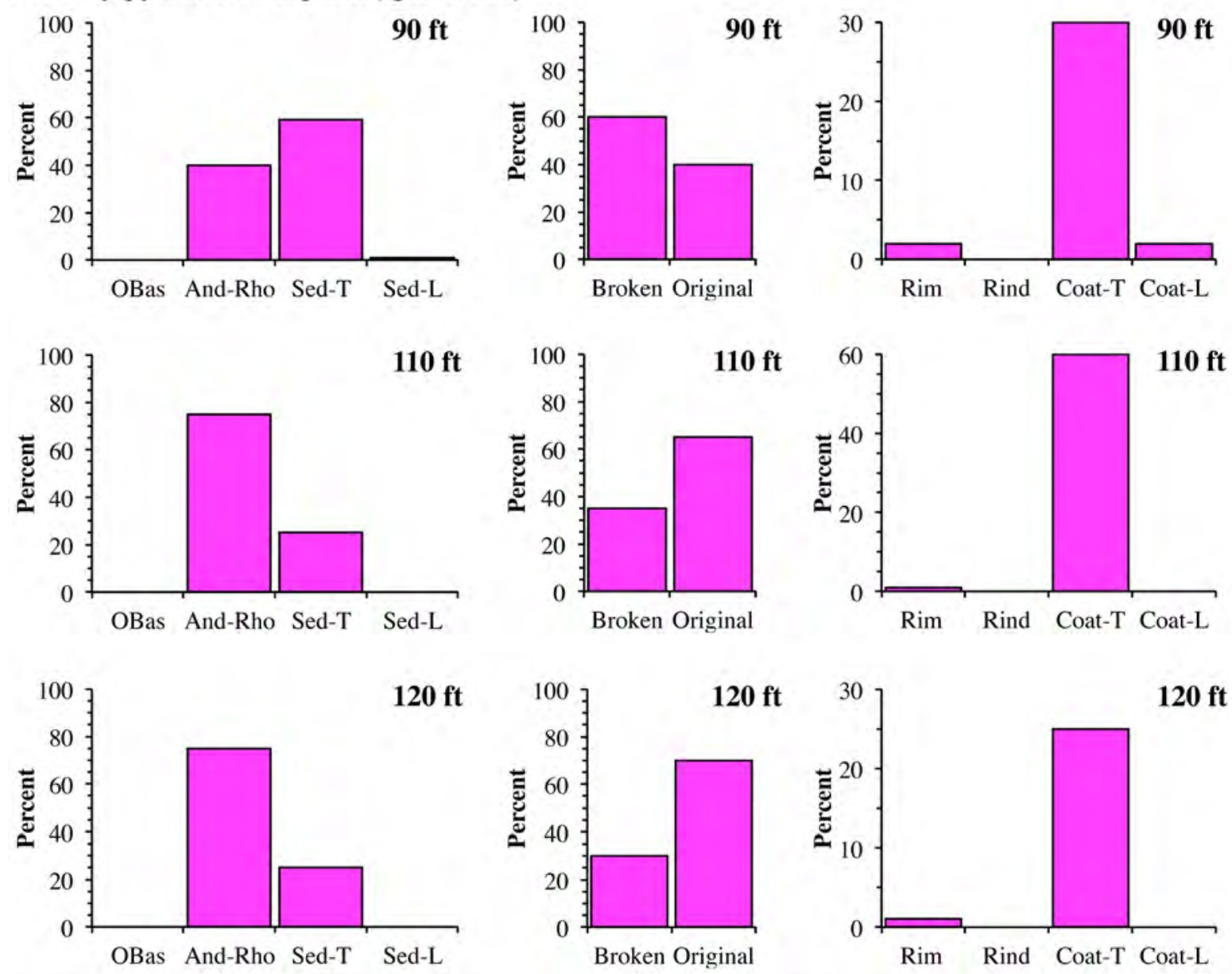

Tuffaceous sedimentary rocks with minor amounts of lithic-rich sedimentary rocks
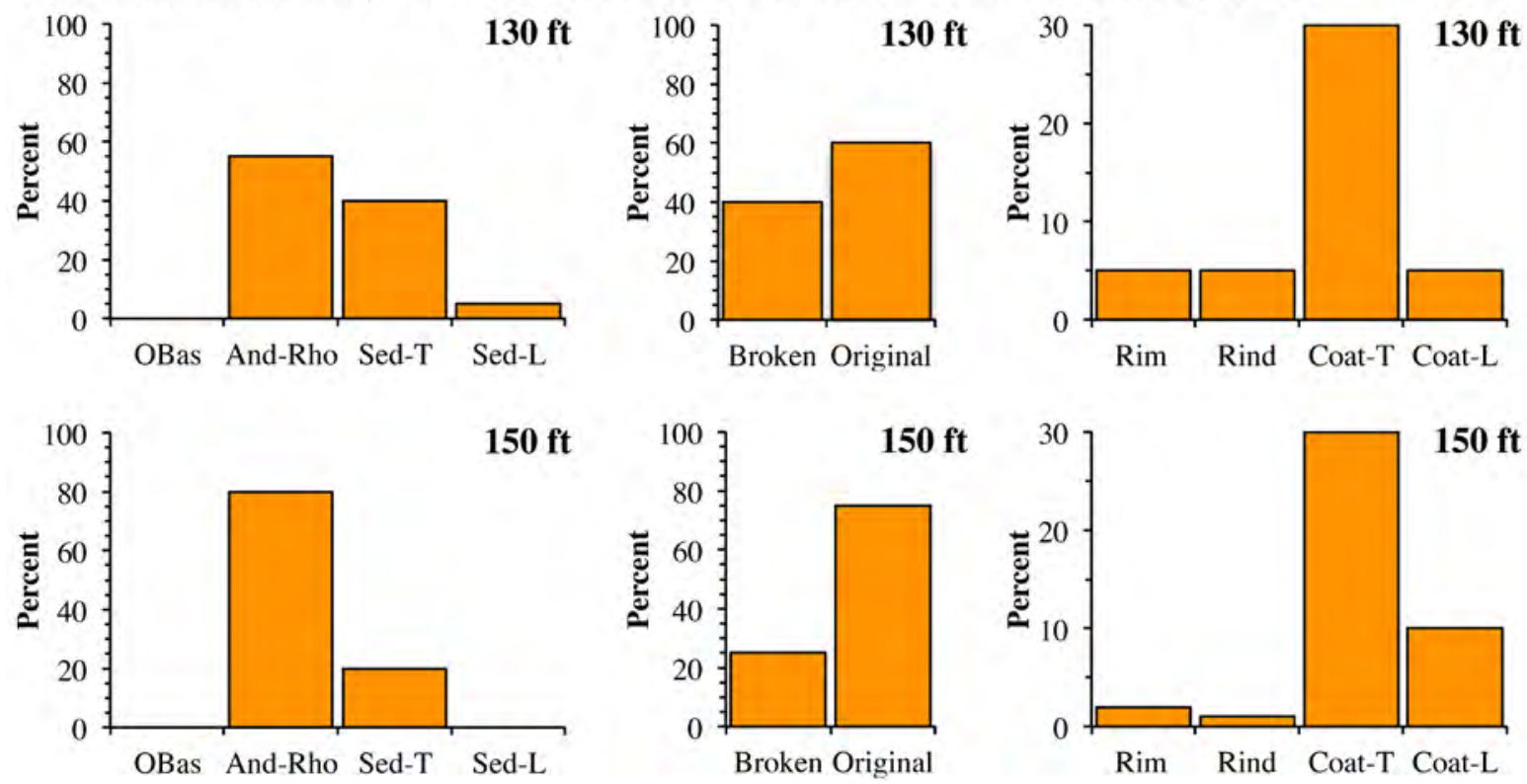

Figure 13.-Continued 

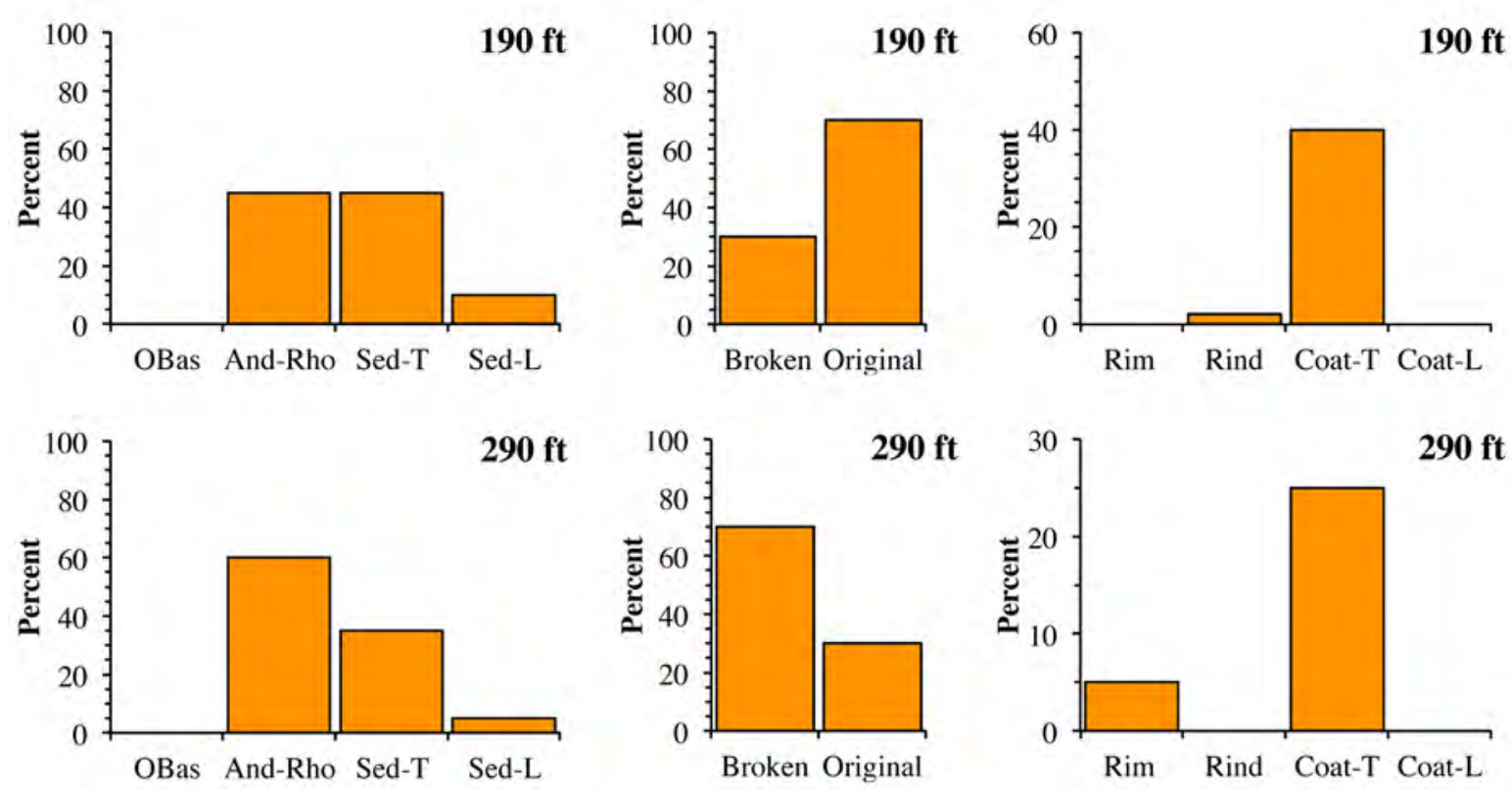

Dacite lava flow or monomictic breccia (avalanche or sedimentary deposit)
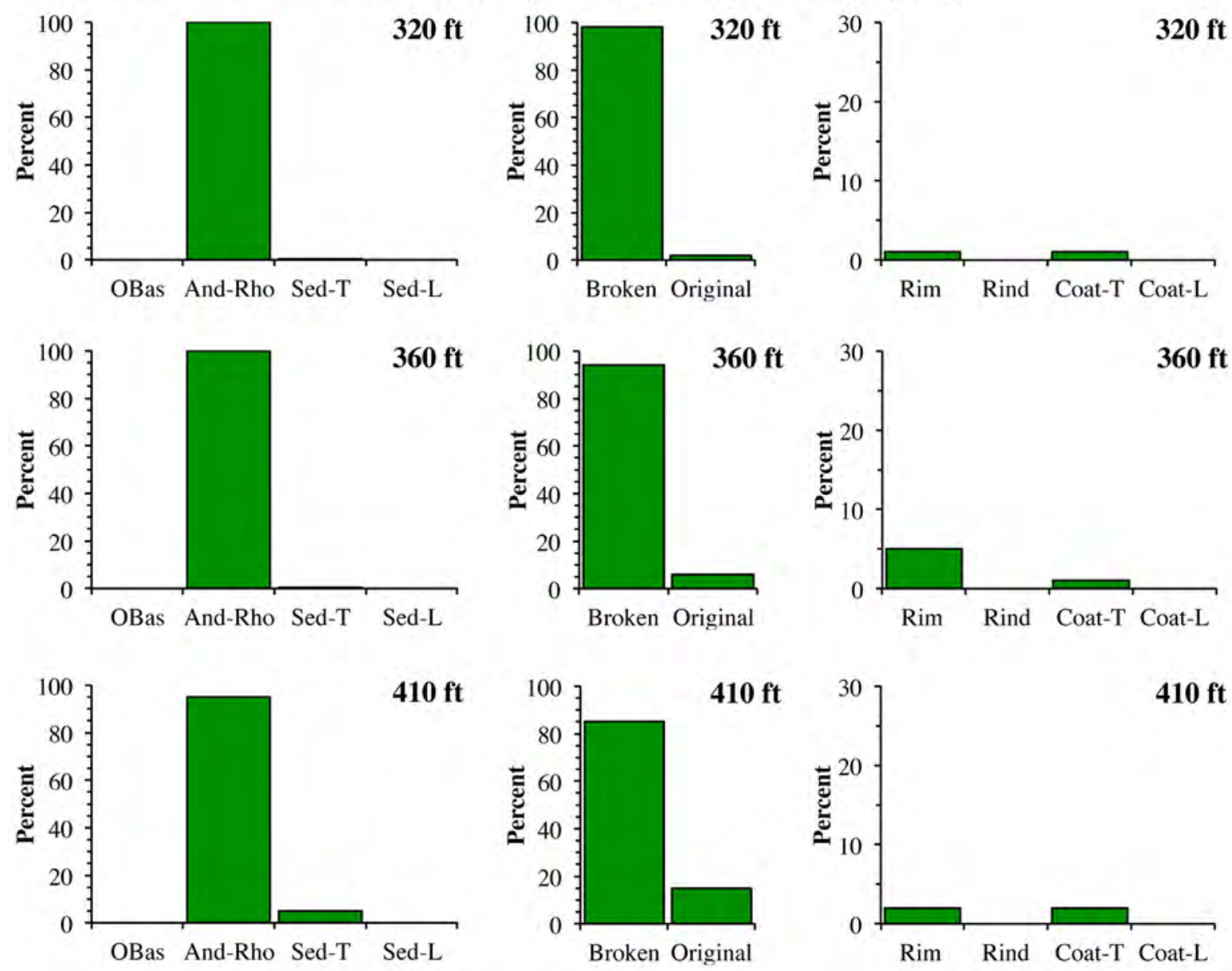

Figure 13.-Continued 
Tuffaceous sedimentary rocks with lithic-rich sedimentary rocks
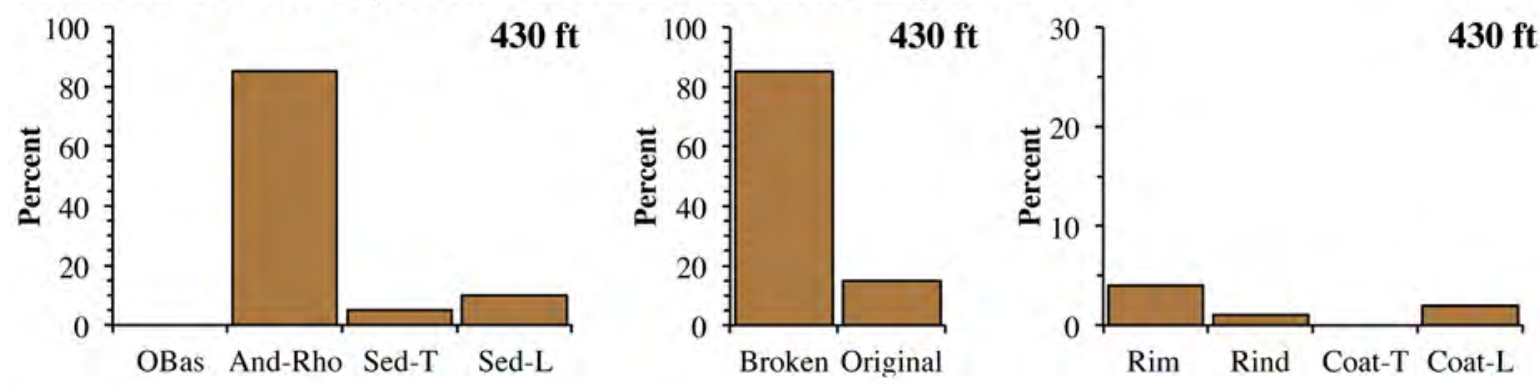

Possibly pyroclastic deposit (ignimbrite)
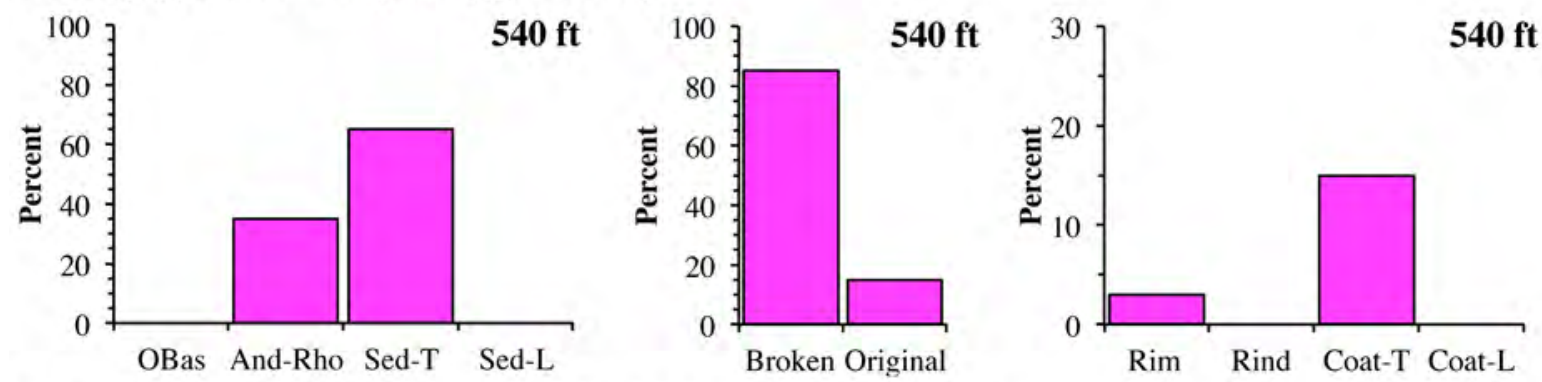

Tuffaceous sedimentary rocks with lithic-rich sedimentary rocks
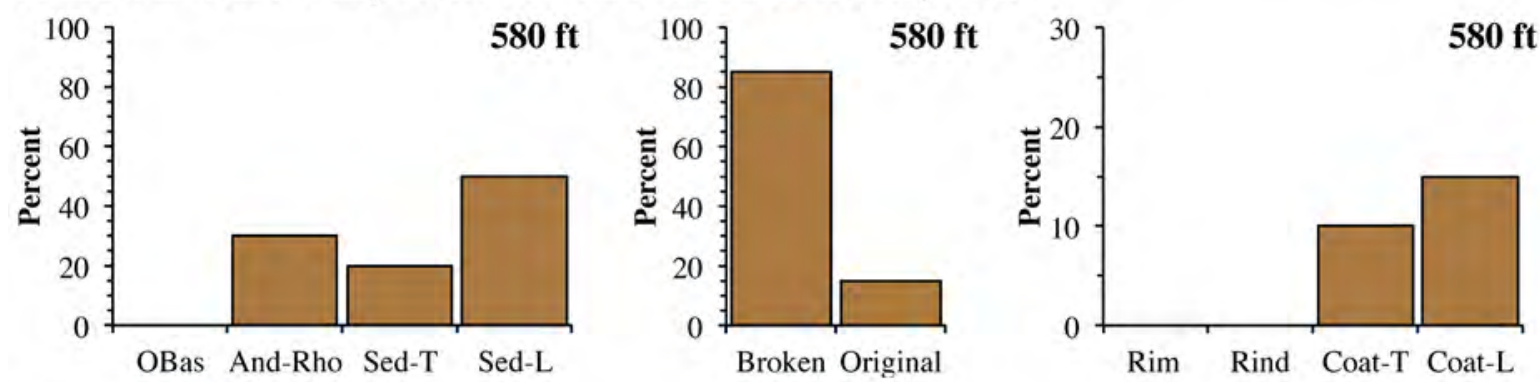

Olivine basalt flows
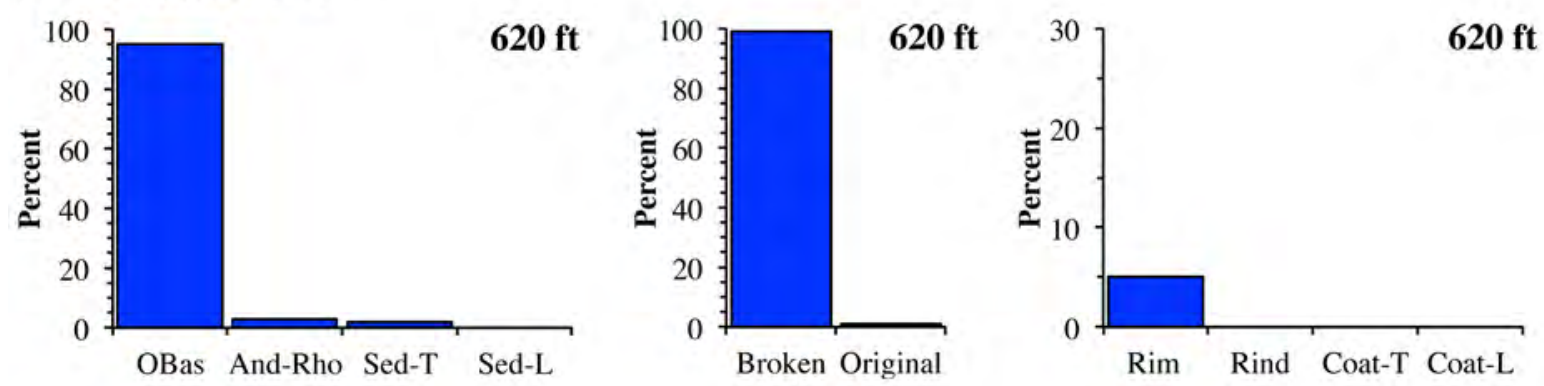

Figure 13.-Continued 

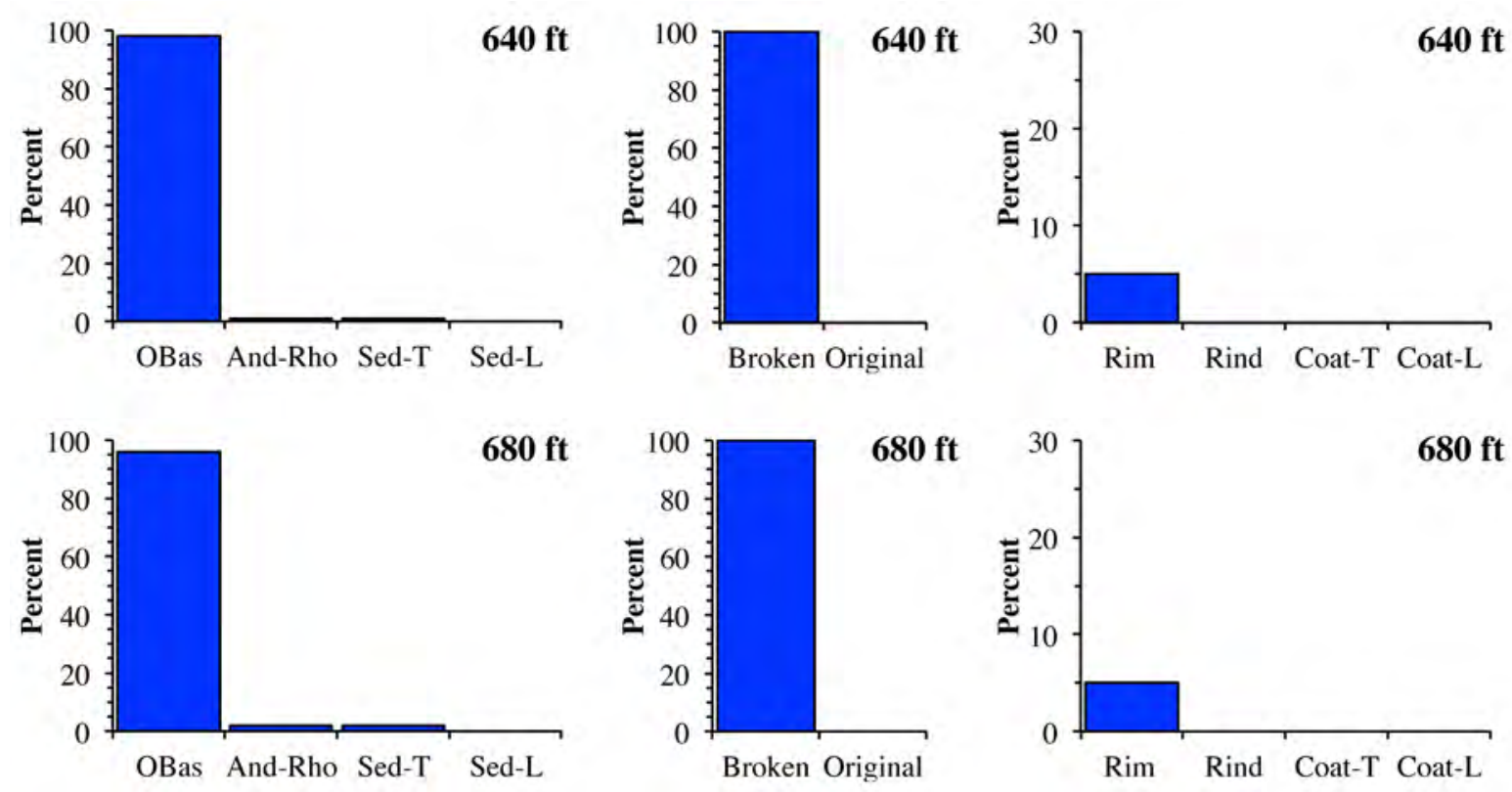

Figure 13.-Continued

appear to be unaltered, and have glassy (or partially glassy) shards and pumice clasts; however, deeper in the section, many of the shards and pumice clasts are slightly altered (possibly to clay? minerals) that gives them an opaque waxy luster. Based on the shapes of lithic clasts and the amount of broken versus original edges on the fragments, many original clasts are less than 2-5 $\mathrm{mm}$, and most samples have original lithic clasts that are probably $5-15 \mathrm{~mm}$ in diameter. Some clasts in some beds can be as large as $30 \mathrm{~mm}$ in diameter. Some samples have fragments that the diameter of the fragment could not be estimated because the original surface was too flat or planar compared to the size of the fragment to estimate a radius; however, the assumption is that these fragments are derived from fragmentation of large rounded lithic clasts.

\section{Detailed Observations on the Deposits from 82 to $294 \mathrm{ft}$}

- Bulk cuttings samples from the shaker table have several intervals with similar colors (fig. 11). At $90 \mathrm{ft}$, the bulk samples are red to reddish yellow, and the color gradationally changes with depth to pink to very pale brown or yellow at $120 \mathrm{ft}$. From 130 to $210 \mathrm{ft}$, the cuttings are pinkish gray to light gray; however, the interval from 200 to $203 \mathrm{ft}$ (which was cored) is pinkish white. From 220 to $240 \mathrm{ft}$, they are light gray to very pale brown. From 250 to $280 \mathrm{ft}$, they are pinkish gray to pale brown gray. The sample at $290 \mathrm{ft}$ is light gray to very pale brown.

- The drill-site rig lithology indicates possible white clay (or ash?) from 108 to $110 \mathrm{ft}$ and 129 to $130 \mathrm{ft}$., but these two intervals were very short and not captured in the regular 10$\mathrm{ft}$ interval of the shaker samples (fig. 11). There are numerous depths associated with rig chatter with "very heavy" sporadic chatter from 100 to $120 \mathrm{ft}$, and frequent chatter to 154 $\mathrm{ft}$ (fig. 12). There is sporadic rig chatter from 169 to $280 \mathrm{ft}$, and beginning at $280 \mathrm{ft}$ there is chatter to $375 \mathrm{ft}$ (fig. 12).

- The detailed analysis of cuttings from eight samples at depths of 80-290 ft indicate that (1) lithic clasts consist of andesite to rhyolite fragments (with no olivine basalt 
fragments), (2) all eight samples have tuffaceous sedimentary fragments that comprise 20-60 percent of the fragments, and (3) four of the eight samples (from 90, 130, 190, and $290 \mathrm{ft}$ ) have lithic-rich fragments that comprise 1-10 percent (fig. 13). Many tuffaceous deposits have $0-5$ percent crystal and (or) lithic clasts, where crystal clasts typically are more abundant than lithic clasts; however, some tuffaceous deposits are described as "lithic-bearing" and have 5-10 percent crystal and (or) lithic clasts.

- Six samples have mostly original surfaces on the lithic clasts, consistent with the plucking of clasts from the host rock, and two samples (at 90 and $290 \mathrm{ft}$ ) have 60-70 percent broken edges, consistent with fragmenting lithic clasts during drilling.

- Five samples have 25-60 percent of lithic clasts coated with tuffaceous matrix, whereas only three samples have $2-10$ percent coated with lithic-rich matrix.

- Three samples (at 80, 90, and $110 \mathrm{ft}$ ) contain fragments of what appears to be pumiceous pyroclastic flow deposits (or ignimbrite) as the tuffaceous fragments. The reddish yellow to pink color of the samples from 90 to $120 \mathrm{ft}$ might be consistent with oxidation of the ignimbrite during cooling of the deposit. Tuffaceous material forms 40 percent of the fragments at $80 \mathrm{ft}$, and some are pumiceous ignimbrite fragments. These fragments might have been eroded from the underlying deposit. If so, the sample at $80 \mathrm{ft}$ is part of the post-ignimbrite sedimentary sequence.

- Borehole geophysical data from gamma, resistivity, and sonic logs between 85 and $294 \mathrm{ft}$ have different characteristics compared to those shallower than $85 \mathrm{ft}$ and deeper than 294 $\mathrm{ft}$ (fig. 12). Gamma values typically are smaller than those shallower than $85 \mathrm{ft}$ and deeper than $294 \mathrm{ft}$. Resistivity values are smaller than those shallower than $85 \mathrm{ft}$ and deeper than $294 \mathrm{ft}$, and there is no change in values across the water table at $173 \mathrm{ft}$. Spontaneous potential values are slightly smaller at depths shallower than $80 \mathrm{ft}$ compared to depths from 80 to $220 \mathrm{ft}$, and there is a gradational increase in values from 220 to 294 $\mathrm{ft}$. Sonic values have minimal variations from 90 to $173 \mathrm{ft}$ (the water table), and there are many more variations in the values from 173 to $294 \mathrm{ft}$; however, variations in sonic values are similar to those below $294 \mathrm{ft}$.

- Between 85 and $294 \mathrm{ft}$, there are numerous examples of cycles in gamma, resistivity, and sonic data; however, the depths and interval lengths of these cycles are not always the same for all of the logs. Representative cycles are labeled in figure 12 as indicated by the length and orientation of the arrows. Cycles can have a series of waveforms with wavelength and (or) amplitude that can (1) be similar, (2) increase upward, (3) decrease upward. Gamma values have cycles $15-50 \mathrm{ft}$ thick. Resistivity values have several cycles $20-80 \mathrm{ft}$ thick. Sonic values have cycles $10-30 \mathrm{ft}$ thick.

- Some tops of the cycles are consistent in two or more geophysical logs, and this implies some type of correlation of lithostratigraphic and geophysical properties.

- In summary, these similarities in geophysical log data, from individual waveforms to cycles, are consistent with changes in lithologic features of beds and bedsets, such as primary or slightly redeposited tuffaceous sediments with more or less lithic clasts compared to the matrix.

\section{Dacite Lava Flow or Monolithic (Avalanche or Sedimentary) Breccia (294-418 ft) in GOLD1}

A dacite lava flow or monomictic (avalanche or sedimentary) breccia occurs from 294 to $418 \mathrm{ft}$. The bulk cuttings samples from the shaker table from 300 to $390 \mathrm{ft}$ are reddish brown to light reddish brown and samples at 400 and $410 \mathrm{ft}$ are similar but just a little more red (wet 
samples) (fig. 11). From 280 to $420 \mathrm{ft}$, there was rig chatter (fig. 12). Three samples (at 320, 360, and $410 \mathrm{ft}$ ) are almost entirely crystallized, slightly porphyritic dacite fragments (fig. 13). Most fragments (85-98 percent) have broken edges (fig. 13), and this is consistent with fragmentation during drilling of a lava flow or monomictic breccia (either as an avalanche or sedimentary deposit). The minor variation in color of the bulk cutting samples and the minor amount (5 percent) of tuffaceous sedimentary fragments at $410 \mathrm{ft}$ (fig. 11 and 13) might represent some bedding within the deposit. Alternatively, they might represent minor amounts of contamination from overlying deposits as the cuttings were returned to the ground surface. The waveform character of the gamma-ray and (especially) resistivity log data differs from the data adjacent rocks. The sonic log values fluctuate from about 100 to 300 microseconds per $\mathrm{ft}$ and along many segments of the borehole there are large sonic log values. These variations probably indicate locally hard and large (intact) pieces of rock surrounded by more fractured rock (cooling fractures in lava flows) or clasts in a matrix that is softer and more easily disaggregated. These variations in the geophysical log data might indicate an internal stratification for the deposit. The interpretation of the top and bottom of this dacite deposit is based on an increase in the gamma and resistivity log values over the interval relative to the adjacent intervals (fig. 12).

\section{Miocene(?) Tuffaceous Sediments (418-605 ft) in GOLD1}

The tuffaceous sediments from 418 to $605 \mathrm{ft}$ consist primarily of tuffaceous sedimentary rocks, including a possible ignimbrite from 500 to $565 \mathrm{ft}$ and several slightly more lithic-rich beds. The pumiceous ignimbrite appears to be nonwelded to partially welded and incipiently crystallized and vapor-phase corroded. The top and bottom of the pyroclastic flow deposit were identified based on the similarity of core and cutting samples at $505 \mathrm{ft}$ and $540 \mathrm{ft}$, respectively, and the changes in geophysical log data. Based on color changes of the bulk shaker samples, detailed examination of components, and similarities of intervals of geophysical logs, many of the beds can be a few feet to tens of feet thick, and bedsets can be from 10 to $40 \mathrm{ft}$ thick. Based on the shapes of lithic clasts and the amount of broken versus original edges on the fragments, many original clasts are less than $2-5 \mathrm{~mm}$. Most samples have original lithic clasts that are probably $5-15 \mathrm{~mm}$ in diameter with some clasts as large as $30 \mathrm{~mm}$ in diameter. Some samples have fragments for which the diameter of the fragment could not be estimated because the original surface was too flat or planar compared to the size of the fragment to estimate a radius; however, the inference is that these fragments are derived from fragmentation of large rounded lithic clasts.

\section{Detailed Observations on the Tuffaceous Sediments from 418 to $605 \mathrm{ft}$}

- Bulk cuttings samples from the shaker table have several intervals with similar colors (fig. 11). At $430 \mathrm{ft}$, the sample appears to be fairly lithic rich and is gray to reddish gray with a small amount of fine-grained component that is pinkish gray. From 440 to $490 \mathrm{ft}$ the bulk samples are pink to pale yellow. From 500 to $550 \mathrm{ft}$, they vary from light gray to pale yellow. From 560 to $590 \mathrm{ft}$, there is a sight change in color from light gray or pinkish gray to pink. The sample at $600 \mathrm{ft}$ is pink to very pale brown.

- Only five depths (420, 431, 478, 494, and $571 \mathrm{ft}$ ) are associated with rig chatter (fig. 12). This chatter is indicative of sharp differences in the strength of the drilled materials such as changes in the induration or cementation of beds or large clasts within beds. The relatively low sonic log values throughout this sequence suggests the rocks are 
moderately lithified, but several of these chatter points are where the sonic log values are higher and indicative of less indurated (softer) parts of the rocks.

- The detailed analysis of cuttings from 430, 540, and $580 \mathrm{ft}$ indicate that (1) lithic clasts consist of andesite to rhyolite fragments (with no olivine basalt fragments), (2) tuffaceous sedimentary fragments comprise 5-60 percent of the fragments, and (3) lithic-rich fragments comprise 0-50 percent (fig. 13). Most samples have predominantly broken edges on the lithic clasts, and this is consistent with fragmenting lithic clasts during drilling. Tuffaceous or lithic-rich coatings on lithic clasts are not common, with tuffaceous coatings on $0-15$ percent of lithic clasts and lithic-rich coatings on 0-10 percent. The sample at $540 \mathrm{ft}$ contains fragments of what appears to be an ignimbrite that is nonwelded to partially welded and is incipiently crystallized and vapor-phase corroded.

- Borehole geophysical data from gamma, resistivity, and sonic logs between 418 and 605 $\mathrm{ft}$ have different characteristics (including smaller values) compared to those shallower than $418 \mathrm{ft}$ and deeper than $605 \mathrm{ft}$ (fig. 12). Although locally there are small variations in the gamma, resistivity, sonic, and spontaneous potential values, there are intervals from 10 to $40 \mathrm{ft}$ in length where the characteristics of the data are similar.

- These similarities in geophysical log values are consistent with changes in lithologic features of beds and bedsets such as primary or slightly redeposited tuffaceous sediments with more or less lithic clasts compared to the matrix. However, the depths and interval lengths of the geophysical log cycles are not always the same for all of the logs, and this indicates that although some properties are shared by the beds or bedsets, other properties (induration, for example) might span a thicker sequence of beds.

\section{Olivine Basalt Flow (605-684 ft) in GOLD1}

Olivine basalt lava flows occur from 605 to $684 \mathrm{ft}$. The bulk cuttings samples from the shaker table include dark gray fragments of lava flows, reddish brown cuttings that probably represent oxidized tops and (or) bottoms of flows, and very pale brown cuttings that probably represent tuffaceous interbeds (fig. 11). Throughout the interval from 605 to $680 \mathrm{ft}$ there was light and sporadic rig chatter (fig. 12). Three samples (at 620, 640, and $680 \mathrm{ft}$ ) are 95 to 98 percent crystallized, porphyritic olivine basalt fragments (fig. 13), and the remaining 2 to 5 percent of the fragments are probably minor amounts of contamination from overlying deposits as the cuttings were returned to the ground surface. Most fragments (between 99 and 100 percent) have broken edges, consistent with fragmentation during drilling of a lava flow. The minor variation in color of the bulk cutting samples and variations in all geophysical log data are consistent with lava flows from 5 to $20 \mathrm{ft}$ thick (fig. 12). The core sample from 680 to $684 \mathrm{ft}$ contains sparsely vesiculated, crystallized, porphyritic olivine basalt lava flow that overlies a clinker (pieces of vesiculated basalt) zone or basaltic clast-rich pebbly conglomerate.

\section{Detailed Observations on the Olivine Basalt Flows from 605 to $680 \mathrm{ft}$}

- Bulk cuttings samples from the shaker table from 610 to $680 \mathrm{ft}$ are dark gray, reddish brown to red, and very pale brown to yellow. The variations in color from grey to red are consistent with sampling unoxidized and oxidized parts of lava flows (near the top and bottom). Yellow colors are consistent with tuffaceous interbeds (these colors are from wet samples) (fig. 11). 
- The rig lithology log indicates the first occurrence of basalt fragments at $605 \mathrm{ft}$. There was "light and sporadic" rig chatter from 605 to $680 \mathrm{ft}$ with specifically identified chatter at $645 \mathrm{ft}$ (fig. 12). The chatter at $645 \mathrm{ft}$ is within a $5-10 \mathrm{ft}$ thick set of variations in the geophysical logs compared to adjacent rocks (especially the high resistivity and low sonic values) that indicate dense and hard rocks, such as a lava flow.

- Three samples (at 620, 640, and $680 \mathrm{ft}$ ) are entirely crystallized, porphyritic olivine basalt fragments (fig. 13). Most fragments (between 85 and 98 percent) have broken edges, and this is consistent with fragmentation during drilling of a lava flow. There are minor amounts of tuffaceous sedimentary fragments in these samples, consistent with either a minor amount of interbeds in the sample interval, or contamination as the cuttings were returned to the surface. Approximately 5 percent of the cuttings fragments contain edges that appear to be slightly different than the remainder of the rock, and these edges might be related to cooling fractures in the basalt lava flows.

- The top of the olivine basalt flow is based (in part) on the sharp decrease of gamma log values and increase of the resistivity log values compared to values for the overlying tuffaceous deposits. The sharp decrease in gamma values is consistent with the compositional difference between basalt compared to the more silicic rocks in the tuffaceous sedimentary rocks. Smaller gamma values for basalt compared to superjacent and subjacent sedimentary rocks have been demonstrated in other boreholes at Fort Irwin that penetrated basalts, including CRTH1, CRTH2, SBTW, and SBMC (Kjos and others, 2014). Small gamma values in basalt are also consistent with the general relations that gamma values are typically influenced by the amounts of $\mathrm{K}, \mathrm{U}$, and Th (Keys and MacCary, 1971; Keys, 1990), and these elements are less concentrated in basalts than in more silicic (andesitic to rhyolitic) rocks.

- Several of the localized increased resistivity values are consistent with the dark basalt cuttings samples at 610,640 , and $670 \mathrm{ft}$ (fig. 11), and this is consistent with the denser (or solid) cores of lava flows, rather than the rubble (or clinker) at the top or bottom of flows or with interstratified bedded deposits. The two resistivity logs RES(16N) and RES(64N) display waveforms that might be indicative of the thickness of the solid cores of the lava flows (that is, considering the solid cores as bed thickness), and serve as a good reminder of the complexities of geophysical log values, sensor spacing, and bed thickness. Both the RES(16N) and RES(64N) logs have broad peak values at about $645 \mathrm{ft}$ and $670 \mathrm{ft}$, and this is consistent with bed thicknesses within the spacing of the sensors. There is a similar set of peaks with these two logs at $627 \mathrm{ft}$, but the RES(64N) peak is not as large as the RES(16N) peak, and this is consistent with the bed thickness being thicker than the RES(16N) sensor spacing and only slightly thicker than the RES(64N) sensor spacing. The RES(16N) and RES(64N) negatively covary from 607 to $622 \mathrm{ft}$, consistent with bed thickness being thicker than the RES(16N) sensor spacing and thinner than the RES(64N) sensor spacing.

- The sonic log has large changes in values that are also consistent with interstratified dense lava flows and sedimentary deposits. The best correlations of high RES(16N) resistivity and low sonic values, each indicative of solid and hard rock, might have a slight (5 ft) depth shift with sonic values being slightly deeper relative to resistivity values. There are good correlations of the RES(64N) and sonic values, although locally they positively or negatively covary. The broad resistivity peak from 660 to $680 \mathrm{ft}$ (which is indicative of solid rock) correlates to an interval of large sonic values (which is 
indicative of soft rock). This apparent disconnect in log values might represent the different sectors of the wall that each tool sampled during the different logging runs. For example, the resistivity log might have sampled the solid rock, and the sonic log sampled a cooling fracture (or set of fractures).

\section{Summary of Lithostratigraphic Features and Units in Borehole GOLD1}

Borehole GOLD1 penetrates gravels and sands from 0 to $70 \mathrm{ft}$ that are provisionally assigned an age of Quaternary and Pliocene(?), and tuffaceous sedimentary deposits (with a few lava flows and possibly a monolithic avalanche breccia) from 70 to $680 \mathrm{ft}$ that are provisionally assigned an age of Miocene(?) (table 3). Deposits are interpreted as Miocene(?) where tuffaceous material is commonly observed in the Miocene(?) sedimentary deposits.

The tuffaceous deposits are interpreted to be primary pyroclastic flow or fallout tephra deposits or redeposited tuffaceous materials. The tuffaceous matrix formed when there was abundant ash that could be incorporated into the matrix of sedimentary rocks either as primary deposits or as material that was eroded and redeposited. Many Miocene(?) tuffaceous deposits have $0-5$ percent crystal and (or) lithic clasts, where crystal clasts typically are more abundant than lithic clasts. Other tuffaceous deposits are "lithic-bearing" and have 5-10 percent crystal and (or) lithic clasts, where lithic clasts are typically more abundant that crystal clasts.

Lithic-rich deposits, which have greater than 30 percent lithic and (or) crystal clasts, are primarily found in (and characteristic of) the Quaternary and Pliocene(?) deposits, but are occasionally observed sporadically interstratified with the Miocene(?) tuffaceous deposits. The lithic-rich matrix characteristic of these deposits formed either (1) where fine ash particles were winnowed from the sediment by surface processes (such as by streams) leaving the lithic clasts behind, or (2) where the material forming the matrix was derived from exposed nontuffaceous rock, thereby forming epiclastic detrital fragments.

Several depositional sequences in GOLD1 are probably exposed at the ground surface in the nearby hills (Buesch and others, 2018). The monomictic (porphyritic dacitic?) breccia and prebreccia tuffaceous and lithic-rich sediments (which include a nonwelded to partially welded ignimbrite) in the borehole probably correlate to similar rocks exposed in the northeastern part of Goldstone Mesa. Goldstone Mesa and Stone Ridge to the east (fig. 2) are capped by a sequence of porphyritic olivine basalt flows deposited on tuffaceous and lithic-rich sedimentary rocks, and locally the basalt appears to onlap low-relief highlands of these tuffaceous and lithic-rich sedimentary rocks. The porphyritic olivine basalt in the borehole probably correlates to exposures of similar olivine basalts in the northwestern part of the Pioneer Plateau (fig. 2) because on the plateau the olivine basalt is interstratified with tuffaceous rocks whereas on Goldstone Mesa and Stone Ridge the olivine basalt forms the top of the Miocene section. Whole rock chemistry has not been used to compare the olivine basalt in the borehole to the basalts exposed in the surrounding areas.

The cuttings samples from GOLD1 are indicative of the quality of samples one might expect from the drilling and sample handling processes. Cuttings are the fragments of rocks that are mechanically fractured or disaggregated during drilling, so the drilling and sampling processes typically are not conducive to the preservation of potentially fragile textures and structures in the matrix of sedimentary deposits. Sample handling in the laboratory can be controlled with gentle washing, and sample structures, such as matrix adhering to cuttings fragments, can be preserved to some extent. However, for cuttings samples derived from nonlithified deposits, even the gentlest washing and sieving can remove the matrix material from 
the cuttings fragments. For many cuttings samples in borehole GOLD1, enough of the tuffaceous or lithic-rich matrix is included as fragments or as coatings that it can be identified with detailed analysis, resulting in viable inferences of the composition of the original sediment and matrix. If a core is available, it can produce samples that are less ambiguous for interpretations of rock types, and it helps form a foundation for interpretations that are derived from the more difficult to work with cuttings.

\section{Lithostratigraphy in Borehole NELT3}

Borehole NELT3 is located on the valley floor west of Nelson Lake (fig. 2). The highlands surrounding the west end of the valley consist of Miocene lava flows, pyroclastic deposits, and clastic sedimentary deposits to the south, west, and north, and pre-Tertiary felsic plutonic rocks (mostly Cretaceous granite) to the north (Miller and others, 2014). Lava flows in the area include porphyritic olivine basalts or basalts, basaltic andesite, andesite, dacite, and rhyolite. The borehole is located on young alluvial fan deposits (Quaternary geologic map unit Qya) and is on the edge of intermediate alluvial fan deposits (Qia) with older alluvial fan deposits (Qoa) 0.6 kilometer $(\mathrm{km})$ to the south, Miocene felsic volcanic rocks (fv) $0.7 \mathrm{~km}$ to the west, and extremely old alluvial fan deposits (early Pleistocene to early Pliocene, QToa) $1.7 \mathrm{~km}$ to the southeast (symbols and deposit types and distances from Miller and others, 2014). Several faults, including the Nelson Lake Fault, have been mapped in the area, including a fault trace 20$100 \mathrm{~m}$ north of the borehole (Miller and others, 2014).

\section{Borehole Conditions, Sample Collection, and Sample Processing}

The well construction diagram and lithologic shaker and sieve logs (including the rig lithology log) for NELT3 document the conditions during drilling and descriptions of samples collected during drilling of the borehole (Kojs and others, 2014). Similar to borehole GOLD1, borehole NELT3 was drilled using mud-rotary techniques and cuttings samples were collected from the shaker table at 10-ft intervals (fig. 14), and three 5-ft-long core samples were collected at 260, 460, and $660 \mathrm{ft}$ (fig. 15) with core recovery of 80, 24, and 43 percent (respectively). Near borehole NELT3, there are two TEM soundings; NL20 is $155 \mathrm{~m}$ south of the borehole, and NL11 is $134 \mathrm{~m}$ north of the borehole (Burgess and Bedrosian, 2014).

\section{Features Included in Descriptions and Logging}

In borehole NELT3, the methods of sample handling, processing, descriptions, and analysis were the same as used in borehole GOLD1. However, there were a few minor updates to methods and definitions.

The "gentle washing" methods of cuttings were used in an attempt to preserve the matrix material as fragments or coatings on lithic clasts, but additional care was needed. Most cuttings samples were at least partially dried (they were collected in July 2011), and most were damp or moist when prepared in the laboratory (samples at 40 and $80 \mathrm{ft}$ were damp, and most from $120 \mathrm{ft}$ and greater depths were moist). Gentle washing is most effective at removing drilling mud from the fragments and clasts (and not removing the attached matrix or coatings on clasts) when the drilling mud has not dried nor adhered to the clast. All samples had enough strength to maintain a vertical cut face on the half of the sample that remained in the sample container. This cohesive strength also indicated that the partial drying of the samples would require additional rehydration of the drilling mud in order to remove it from the fragments and clasts. Part of the washing of 
cuttings included soaking the samples in water a minimum of 20 minutes. The cuttings were (1) placed in a bread tin, (2) submerged in tap water to a depth of about $2 \mathrm{~cm}$, (3) the mixture stirred gently and some of the larger clumps were poked to see if they disaggregate, (4) the container was gently "vibrated" by hand for about 30 seconds, and (5) then placed on the counter to soak. Samples responded differently to the washing process as follows:

- The samples from 40 and $80 \mathrm{ft}$ had few fines, and one could see the main part of the sample through the water. Any minor amounts of suspended fines settled within a few minutes.

- Most samples from $120 \mathrm{ft}$ and deeper had abundant fines, produced very turbid water, and took over an hour for suspended material to settle. The water in some samples was still slightly turbid after 3 hours.

- A few samples below $120 \mathrm{ft}$ had moderate amounts of fines, moderate turbidity, and settling times for suspended material was on the order of tens of minutes.

- The clearing of the fines in the drilling mud and water during the washing of cuttings from GOLD1 exhibited similar behavior to the settling times for gently washed samples from NELT3 with settling in minutes for samples less than $80 \mathrm{ft}$ deep and taking an hour or more to settle at depths greater than $120 \mathrm{ft}$. Unless the drilling method was modified between about 70 to $120 \mathrm{ft}$, there seems to be a measurable increase in fines in both wells near these depths.

It should be noted that at various depths in this borehole a powder (Quik-Trol) was added to the drilling mud for filtration control and borehole stabilization, and it causes cuttings fragments to clump together with the gelatinous material. When dried, these clumps mimic sedimentary matrix. These clumps are characterized by framework grains bound with thin, very fine-grained material that partially covers grains, and the spans between grains are in a concave, surface tension configuration. These clumps are not included in the tabulation of fragment types. Identification of lithic clasts can be instructive for provenance studies. However, for the logging of NELT3 (and the other NELT-series boreholes), detailed provenance of clasts was not requested, and andesite to rhyolite fragments were grouped into the "And-Rho" category.

Table 3. Estimated depths and thicknesses, in feet, of the Quaternary-Pliocene(?) and Miocene(?) sequences in the GOLD1 and NELT-series boreholes from Fort Irwin, California.

[np, not penetrated; ft, feet]

\begin{tabular}{lcccccccc}
\multicolumn{1}{c}{ Borehole } & GOLD 1 & NELT1 & NELT2 & NELT3 & NELT4 & NELT5 & NELT6 & NELT7 \\
\hline Top (ft) & & & & & & & & \\
Q-Plio(?) & 0 & 0 & 0 & 0 & 0 & 0 & 0 & 0 \\
Mio(?) & 70 & 104 & 107 & 108 & 118 & 130 & 124 & 86 \\
Bedrock & $\mathrm{np}$ & $\mathrm{np}$ & $\mathrm{np}$ & $\mathrm{np}$ & 840 & $\mathrm{np}$ & $\mathrm{np}$ & $\mathrm{np}$ \\
Total depth & 684 & 803 & 725 & 665 & 885 & 905 & 903 & 865 \\
Thickness (ft) & & & & & & & & \\
Q-Plio(?) & 70 & 104 & 107 & 108 & 118 & 130 & 124 & 86 \\
Mio(?) & 614 & 699 & 618 & 557 & 722 & 775 & 779 & 779 \\
Bedrock & & & & & 45 & & & \\
\hline Alternative top (ft) & & 0 & 0 & & & & 0 & \\
Q-Plio(?) & & 78 & 83 & & & 85 & 79 & \\
Mio(?) & & $\mathrm{np}$ & $\mathrm{np}$ & & & $\mathrm{np}$ & $\mathrm{np}$ & \\
Bedrock & 803 & 725 & & & 905 & 903 & \\
Total depth & & & & & & 85 & 79 & \\
Alternative thickness (ft) & & 78 & 83 & & & 820 & 826 & \\
Q-Plio(?) & & 725 & 642 & & & & & \\
Mio(?) & & & & & & & \\
\hline
\end{tabular}


A 마

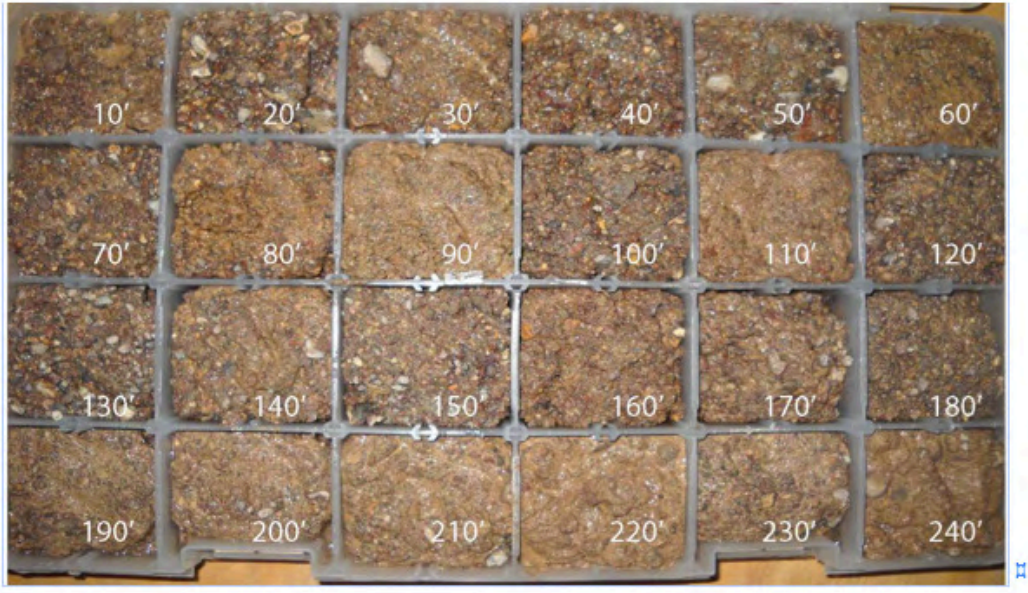

I

$$
\text { I }
$$

$\mathrm{B}$

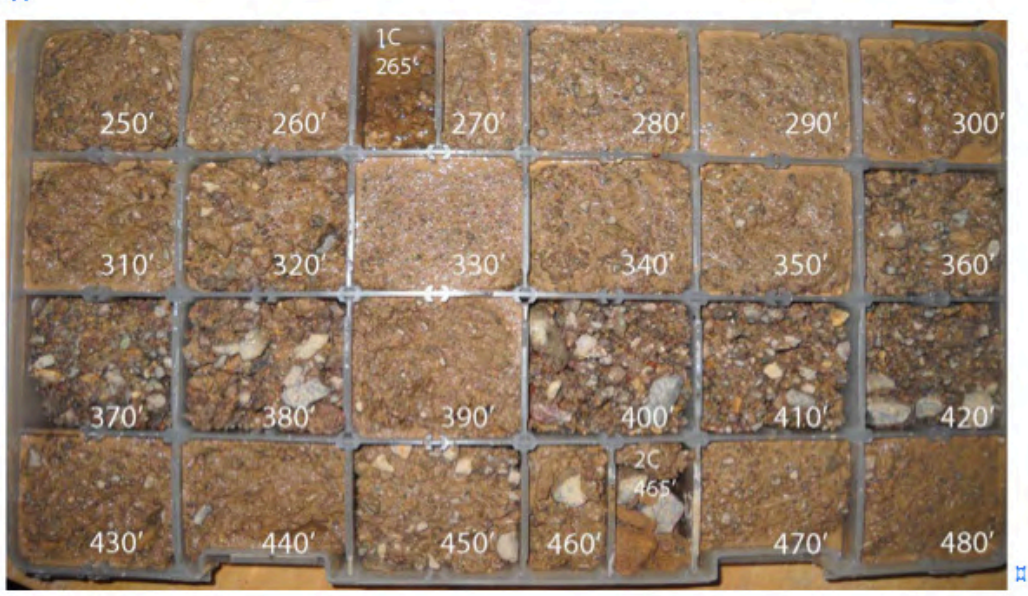

C

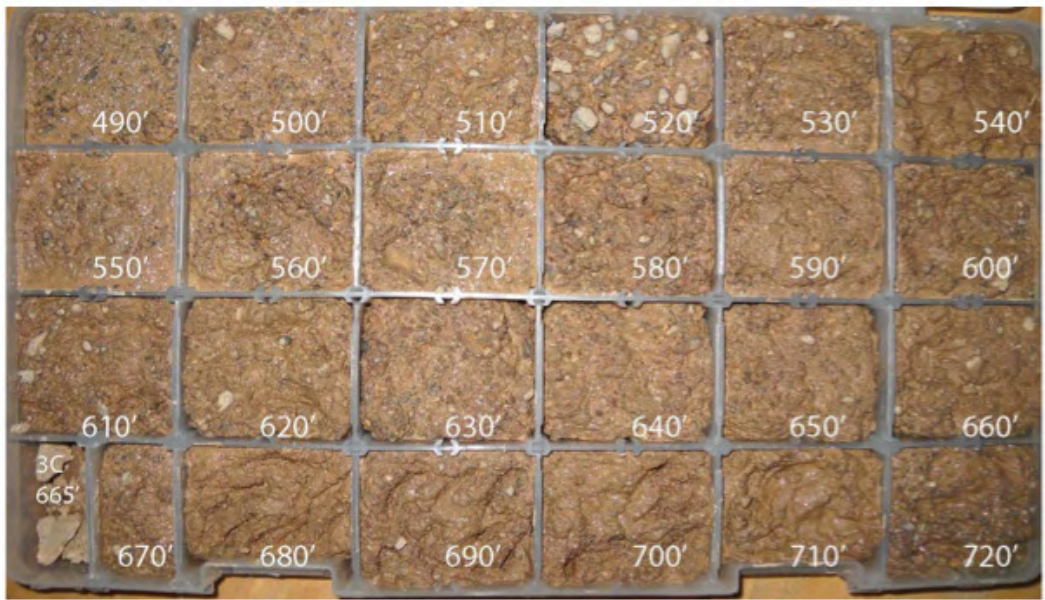

I.

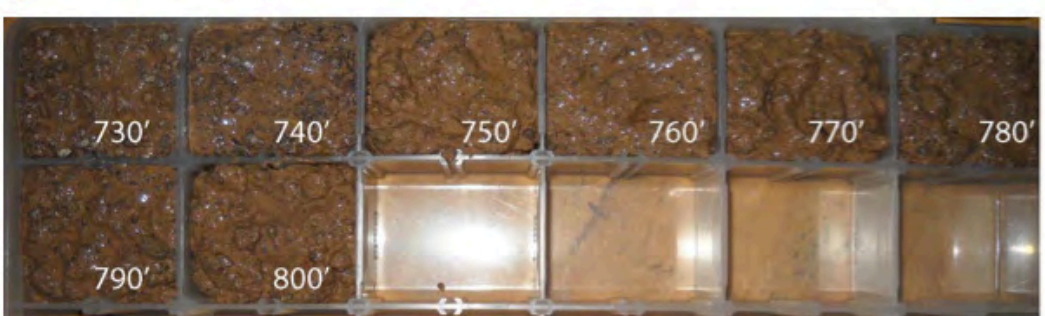

Figure 14. Photographs of cuttings from the shaker table for borehole NELT3 at Fort Irwin, California. $A$, samples from 10 to 240 feet (ft);

$B$, samples from 250 to $480 \mathrm{ft} ; C$, samples from 490 to $720 \mathrm{ft} ; D$, samples from 730 to $800 \mathrm{ft}$. Core samples at 265, 465, and $665 \mathrm{ft}$. A square chip cell is $50 \times 55$ millimeters. U.S. Geological Survey photographs by Anthony Brown. 


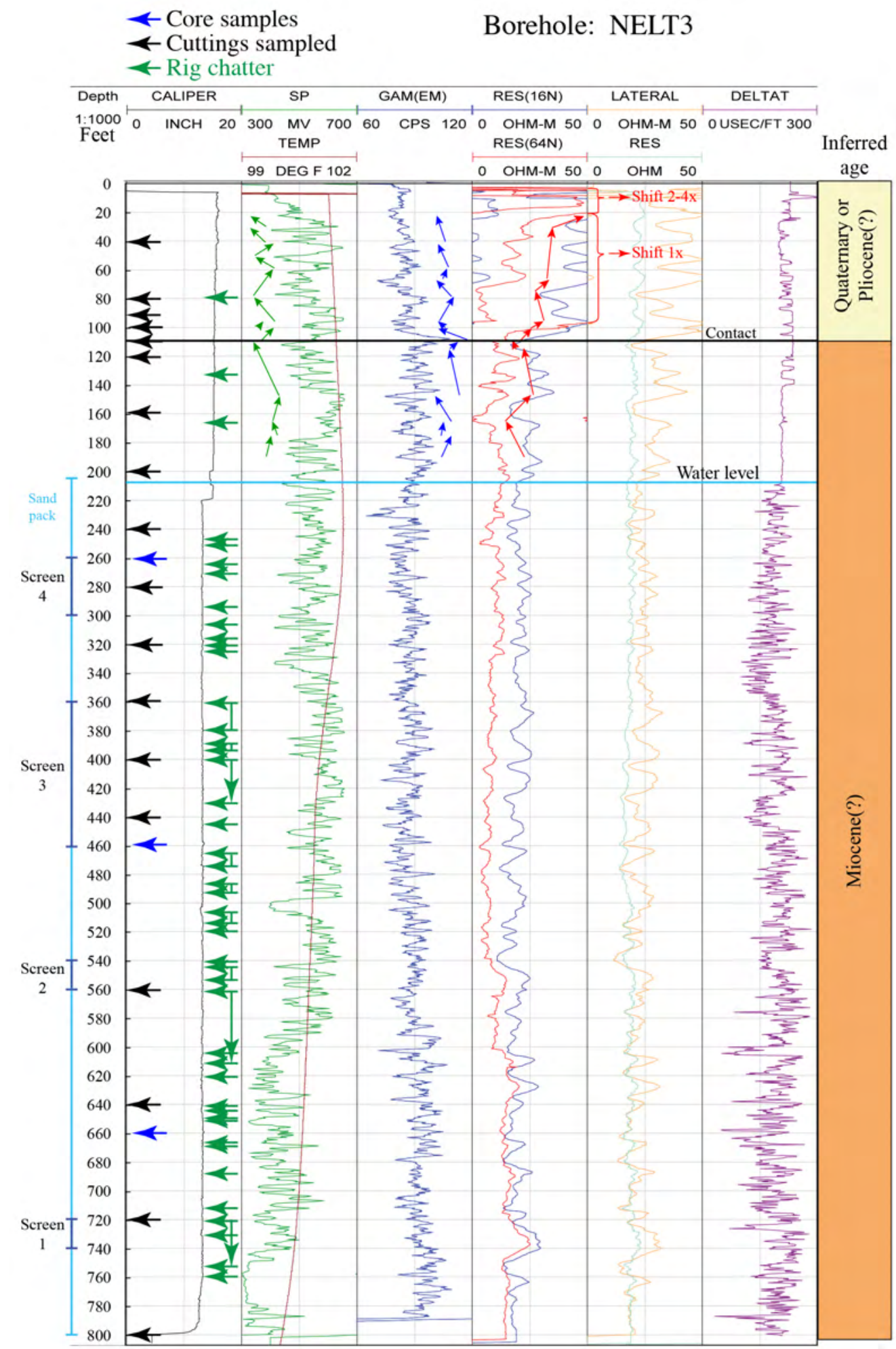

Figure 15. Graph showing locations of cuttings samples in borehole NELT3 at Fort Irwin, California, used for detailed examination compared to core, borehole geophysical logs, rig chatter, and locations of screened intervals 1, 2, 3, and 4 in single well. Rig chatter from Joseph Nawakis (USGS, written commun., 2011). Borehole geophysical logs and depths to screened intervals from Kojs and others (2014). 


\section{Interpretations for Stratigraphy in NELT3}

Detailed component data for NELT3 are summarized in figure 16. All the samples are 95-100 percent clasts of various types of crystallized lava flows with 0-5 percent, slightly altered, tuffaceous deposits that are interpreted as being eroded from the older, altered Miocene section. There are very few fragments of tuffaceous or lithic-rich matrix. The interpretation of these observations is that the matrix in the sedimentary section is very poorly lithified, and simply disaggregates during drilling.

\section{Young (Quaternary to Pliocene?) Alluvial Gravels (0-108 ft) in NELT3}

Samples from 40 and $80 \mathrm{ft}$ include a few fragments of Miocene(?), partially altered, tuffaceous rocks, and all of these original clasts have minor amounts of attached lithic-rich matrix. There is one granitic clast in the sample from $80 \mathrm{ft}$. Most fragments in the sample from $40 \mathrm{ft}$ are less than 5-8 $\mathrm{mm}$ and those from $80 \mathrm{ft}$ are less than 10-15 mm. Many clasts have mostly original shapes and surfaces that are rounded, and a few clasts are well rounded. Lithic clasts have about 25 percent lithic-rich coatings in the sample at $40 \mathrm{ft}$ and 20 percent at $80 \mathrm{ft}$.

Clasts from 90 to $110 \mathrm{ft}$ have mostly original shapes that are rounded (with a few well rounded), and there is a shift from mostly lithic-rich matrix coatings on lithic clasts to mostly tuffaceous matrix (including some lithic-bearing tuffaceous matrix) (fig. 16, table 2.1). At $100 \mathrm{ft}$, there is an abundance of rinds on clasts, and all the rinds are rounded (as are their host clasts). At $110 \mathrm{ft}$, there are small fragments of carbonate-cemented lithic sandstone and a lithic fragment partially covered with a lithic-rich coating, and these might be partly broken rinds. The rounding of clasts with rinds (especially at $100 \mathrm{ft}$ ) might indicate polycyclic clasts that are part of a sedimentary conglomerate. However, it is possible that the rounding of the rinds occurred during drilling, and the final shape of the grain surface was influenced by the shape of the original clast. If these rinds did form in place, then the abundance of rinds is consistent with either (1) a caliche horizon developed in sedimentary rocks near a stable geomorphic surface, or (2) a carbonate cemented horizon at the base of a "valley-filling" alluvial sequence that overlies an unconformity (especially one that results in hydrogeologic ponding of groundwater or water flowing through the unsaturated zone) (Neymark and others, 2007).

There are several cycles in geophysical logs between 22 and $147 \mathrm{ft}$ (fig. 15). From 22 to $108 \mathrm{ft}$, gamma values have several 4-20-ft wavelength cycles with both down-hole increase and decrease in mean values, and internally the cycles have an increase or decrease in amplitude and (or) wavelength. The peak gamma value is at $108 \mathrm{ft}$. From 0 to $108 \mathrm{ft}$, resistivity values are large near the ground surface and decrease downward to $78 \mathrm{ft}$, where there is a small increase that peaks at $95 \mathrm{ft}$, and the decrease continues to $108 \mathrm{ft}$. From 22 to $108 \mathrm{ft}$, spontaneous potential values also have several 4-20-ft wavelength cycles. From 114 to $147 \mathrm{ft}$, gamma, resistivity, and spontaneous potential all have internally complicated, but similarly trending, cycles. The best depth for where these various geophysical values coincide is at about $108 \mathrm{ft}$.

Near borehole NELT3, there are two time-domain electromagnetic (TEM) soundings where there is a sharp decrease in minimum-layer model resistivity at $90 \mathrm{ft}$ in NL11 and at $116 \mathrm{ft}$ in NL20 (Burgess and Bedrosian, 2014). Part of the difference in depths to the decrease in resistivity values is likely because of the distance between the sounding, the shallow slope of the lithostratigraphic units, and NL11 is on the north side of a fault (Burgess and Bedrosian, 2014; Miller and others, 2014). Burgess and Bedrosian (2014) equate the sharp decrease in resistivity in these soundings to their pick of a sharp decrease in borehole resistivity at a depth of $105 \mathrm{ft}$. 
Probably Quaternary to Pliocene(?)
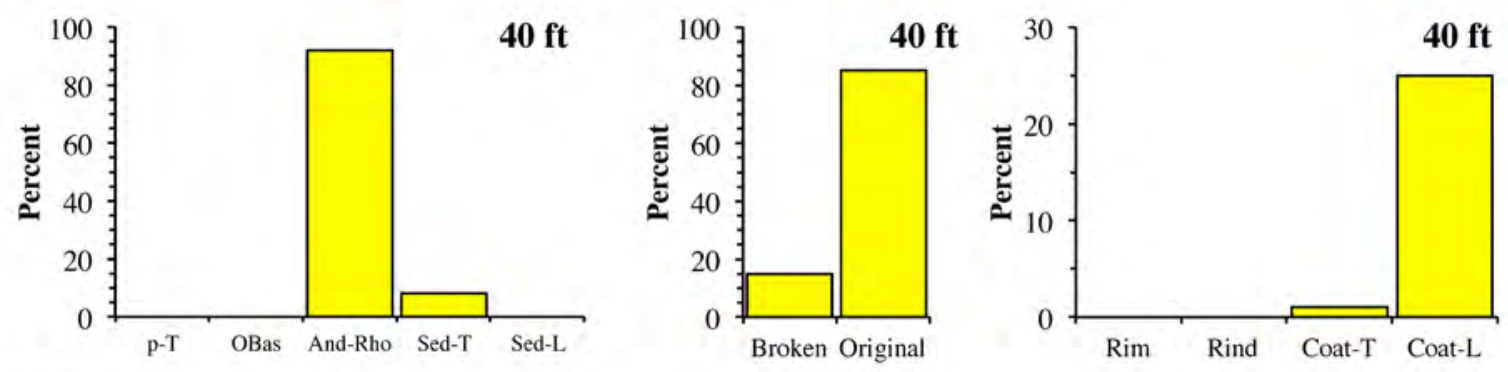

And-Rhy -- Many clasts are polycyclic.

Sed-T -- Epiclastic tuffaceous fragments, partially altered and derived from Miocene(?) section
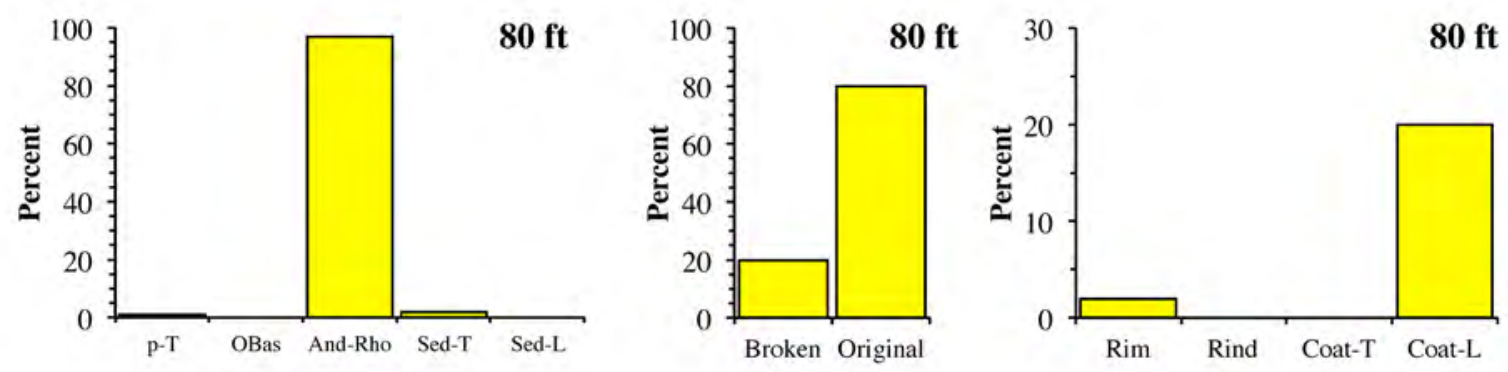

Sed-T -- Epiclastic tuffaceous fragments, partially altered and derived from Miocene(?) section; locally with lithic-rich matrix attached
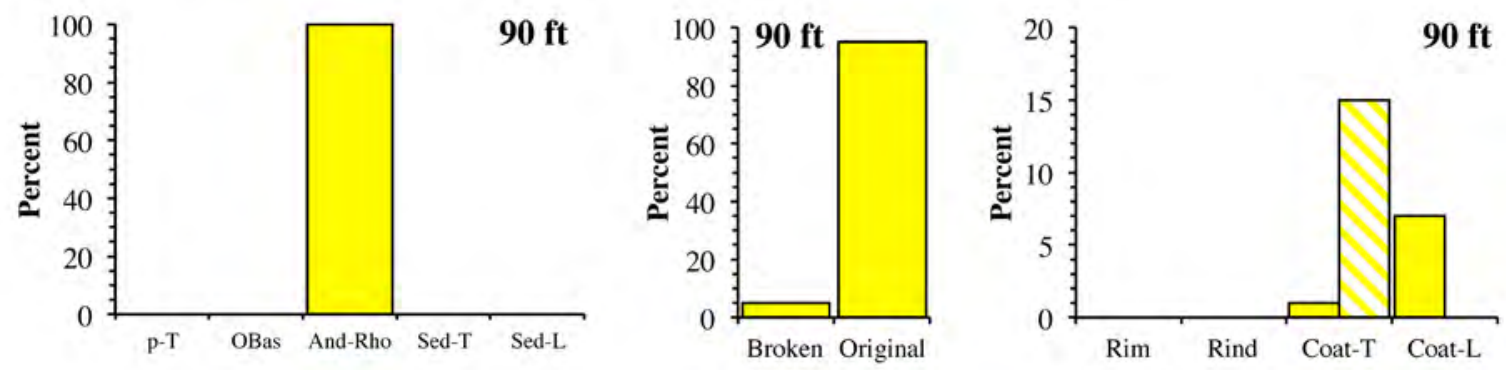

Cross hatched Coat-T are lithic-bearing tuffaceous matrix.

Figure 16. Bar graphs of components of cuttings samples in borehole NELT3 at Fort Irwin, California. Lithostratigraphic units: yellow, lithic-rich sediment, probably Quaternary or Pliocene(?); orange, tuffaceous sediment, probably Miocene(?). Components: p-T, Pre-Tertiary; Obas, porphyritic olivine basalt; And-Rho, andesite to rhyolite; Sed-T, tuffaceous sedimentary rocks, Sed-L, lithic-rich sedimentary rocks; Broken, broken surfaces; Original, original surfaces; Rim, thin layer of crystallization in volcanic rock along a cooling fracture; Rind, calcite, opal, or chalcedony deposits on a lithic clast; Coat-T, tuffaceous coatings; Coat-L, lithic-rich coatings. 

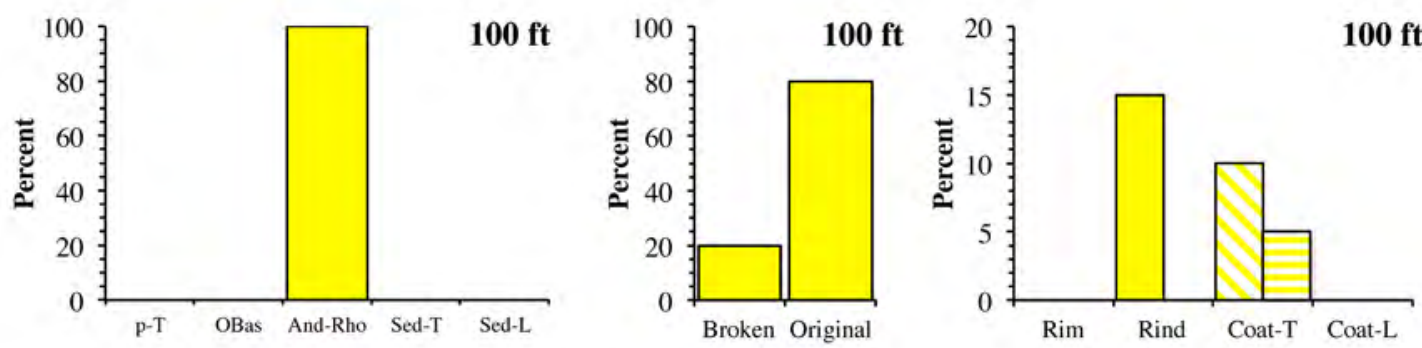

Cross hatched Coat-T are lithic-bearing tuffaceous matrix.

Horizontal stripped Coat-T are lithic-rich tuffaceous matrix.

Probably Miocene(?)
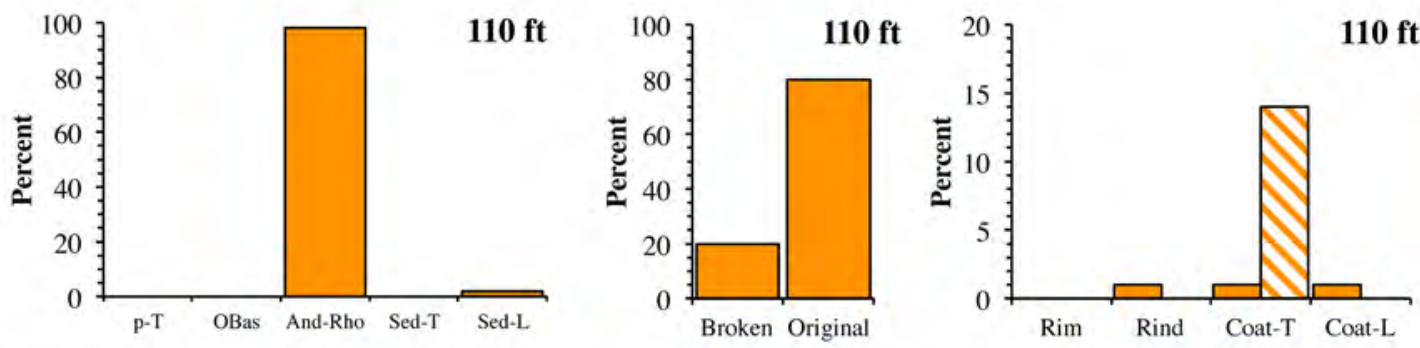

Sed-L -- Carbonate cemented lithic sandstone (small and might be broken rinds).
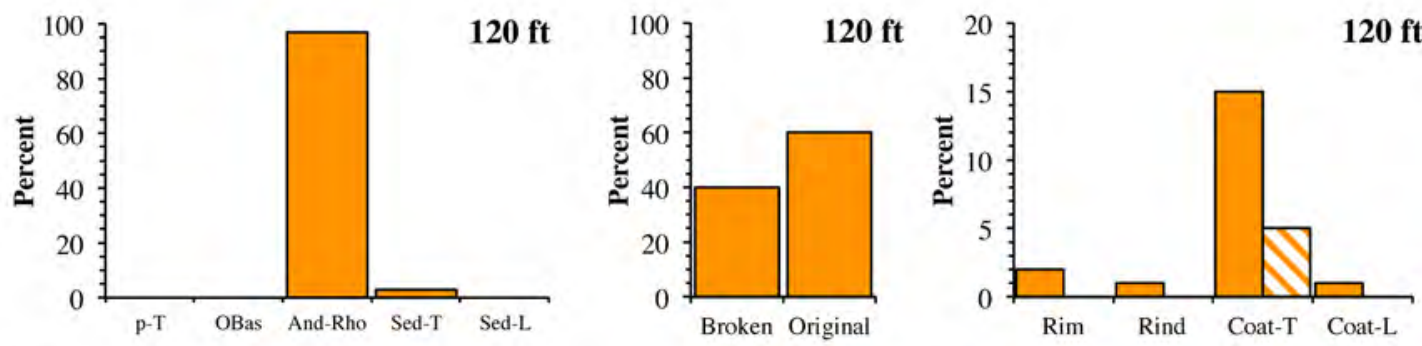

And-Rhy -- Many clasts are polycyclic.

Sed-T -- Epiclastic fragments from eroded (zeolitically altered?) tuffaceous clastic rocks
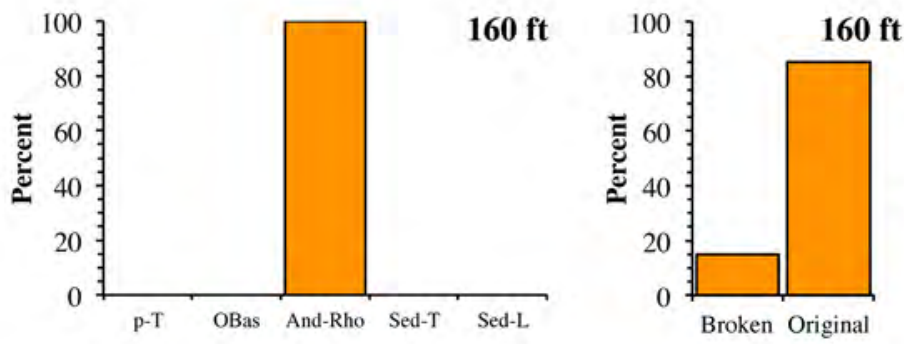

Cross hatched Coat- $\mathrm{T}$ are lithic-bearing tuffaceous matrix.

Solid-fill Coat-T are fine-grained pumice clast-bearing tuffaceous matrix.

Cross hatched Coat-T are crystal-bearing tuffaceous matrix.

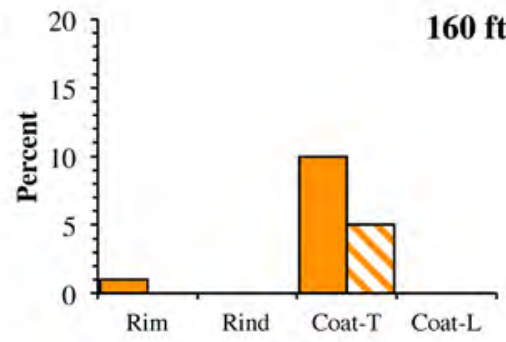

Cross hatched Coat- $\mathrm{T}$ are lithic-bearing tuffaceous matrix.

Figure 16.-Continued 

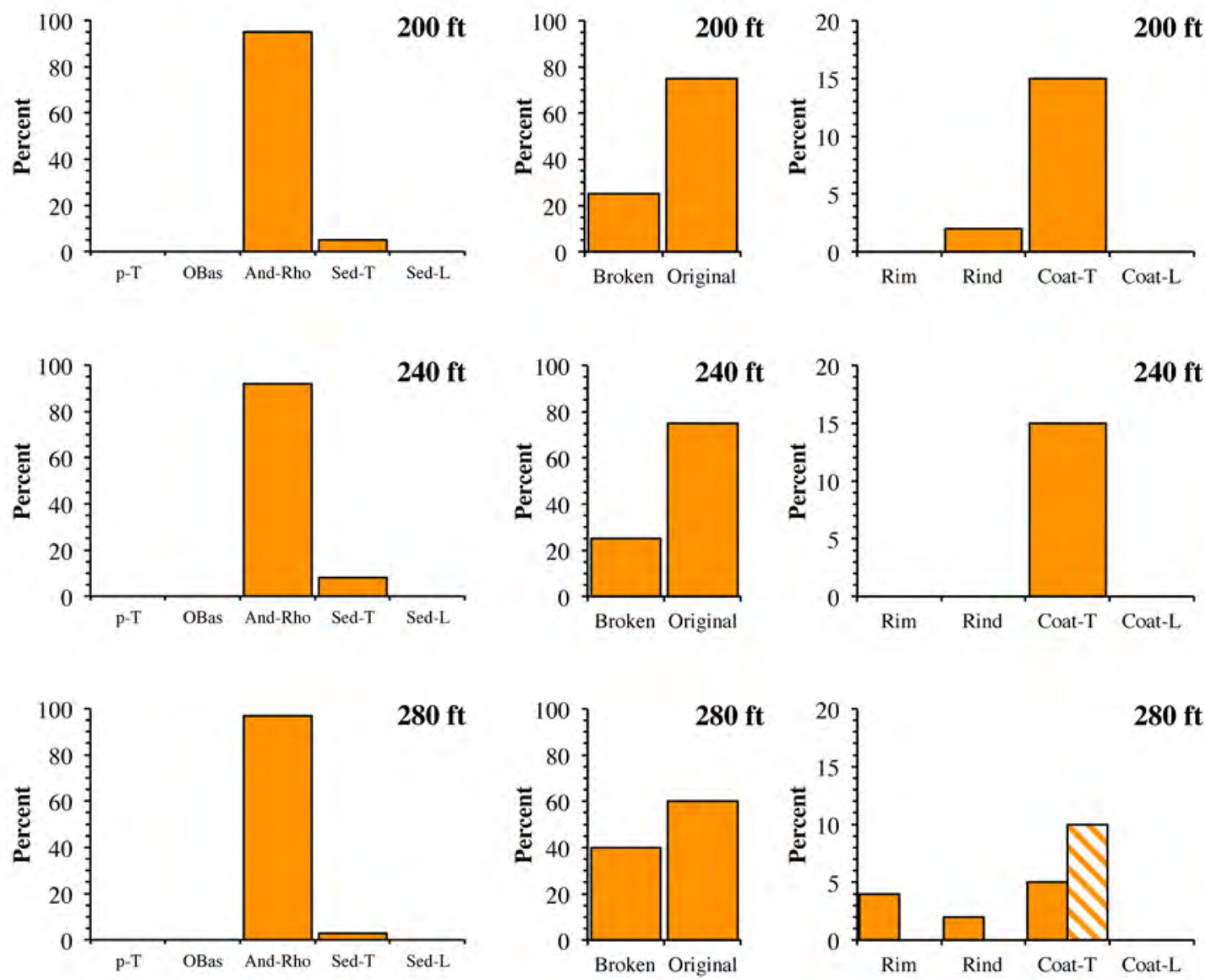

Sed-T -- Broken, tuffaceous (ignimbrite?) as lithic clasts in the host deposit

Cross hatched Coat-T are lithic-bearing tuffaceous matrix.
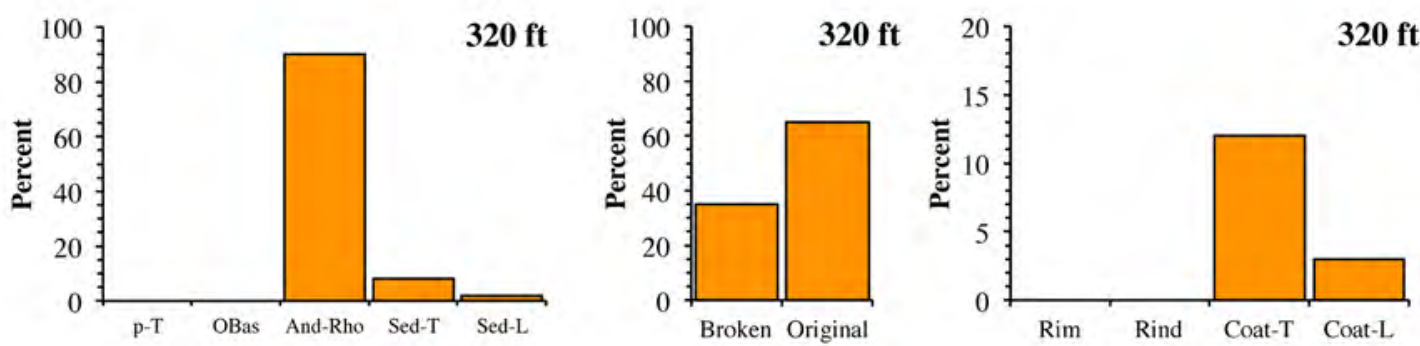

Sed-T -- Lithic clasts, not host rock.

Figure 16.-Continued 


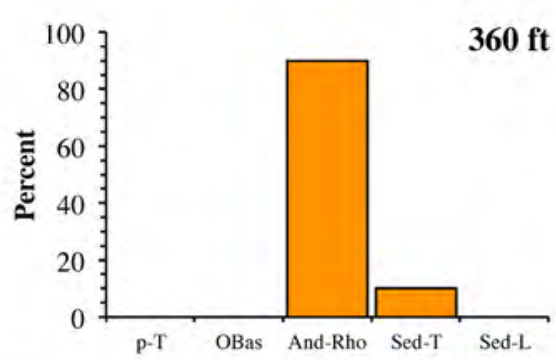

Sed-T -- Lithic clasts, not host rock.

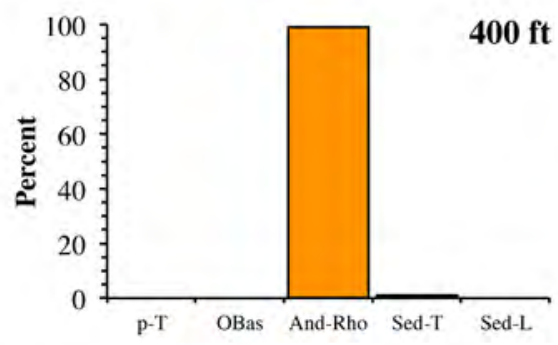

Sed- $\mathrm{T}$ is a white, very fine-grained, tuff
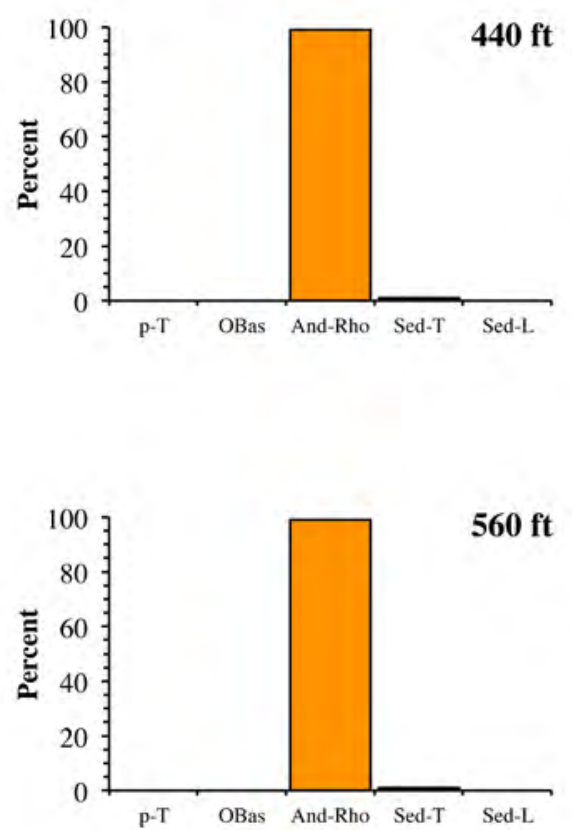
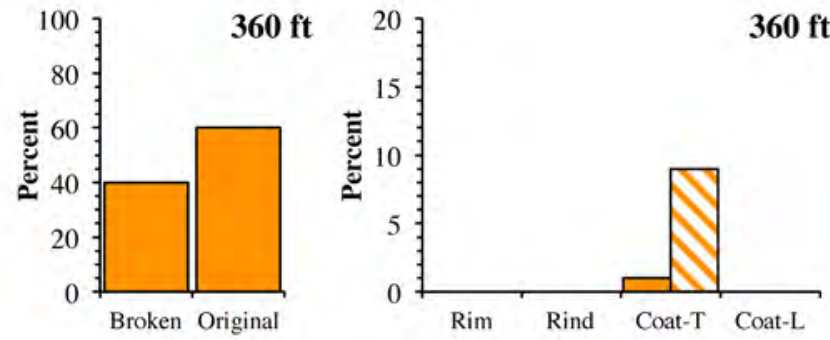

Cross hatched Coat- $\mathrm{T}$ are lithic-bearing tuffaceous matrix.
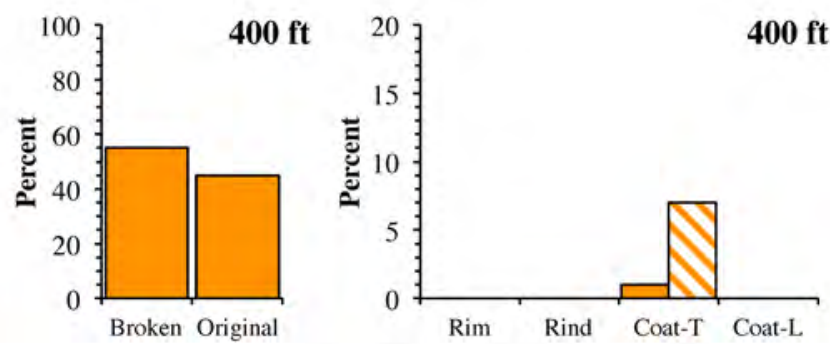

Cross hatched Coat- $\mathrm{T}$ are lithic-bearing tuffaceous matrix.
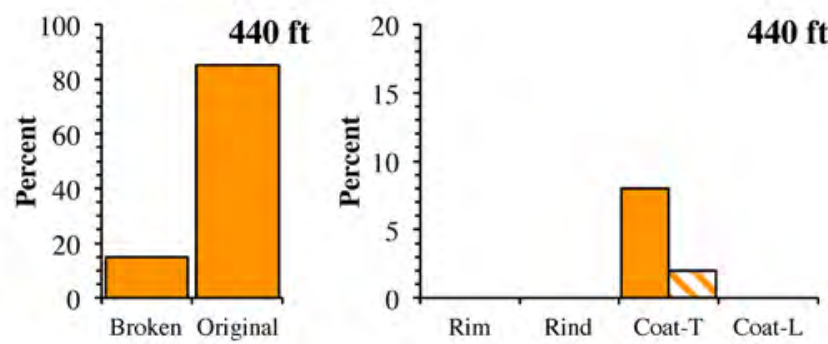

Cross hatched Coat- $\mathrm{T}$ are lithic-bearing tuffaceous matrix.
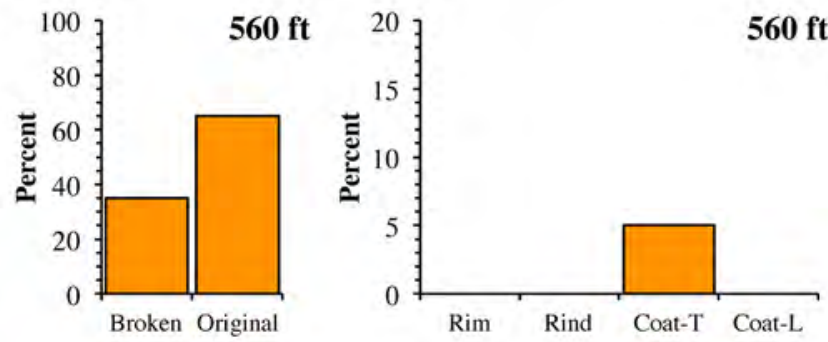

Figure 16.-Continued 

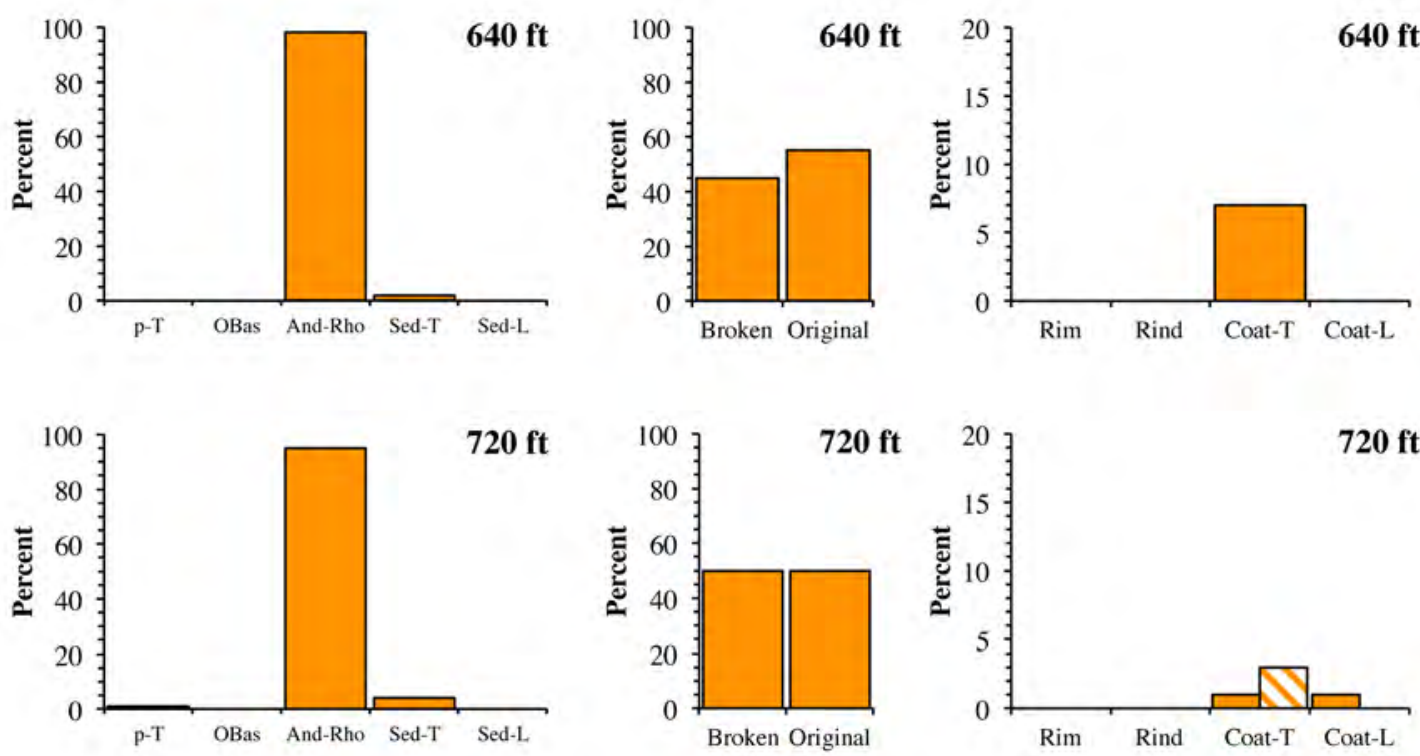

Cross hatched Coat- $\mathrm{T}$ are lithic-bearing tuffaceous matrix.
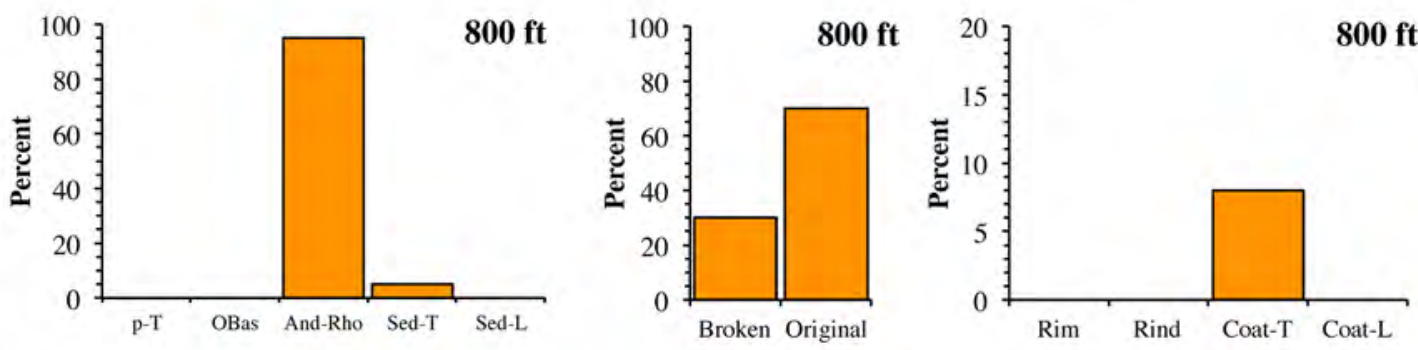

Figure 16.-Continued

\section{Miocene Tuffaceous Sediments (108-800 ft) in NELT3}

In several samples from 110 to $800 \mathrm{ft}$, most cuttings are fragments or clasts of crystallized lava flows, and there are a few fragments of tuffaceous and lithic-rich sedimentary rocks; however, all these cuttings are from parts of Miocene(?) rocks that were clasts in the drilled sedimentary rocks. Some clasts have tuffaceous or lithic-rich coatings that are included in the rounded shape of the clast, and these represent polycyclic clasts.

Many of the volcanic lithic fragments are fractured parts of larger clasts that have part of the rounded and smooth surfaces preserved. Estimated grain sizes are at least $10 \mathrm{~mm}$, commonly $20 \mathrm{~mm}$, and occasionally greater than $20 \mathrm{~mm}$. One implication of these estimated grain sizes is that the fragments came from pebble to possibly cobble (or boulder) conglomerate. Most fragments inferred to be derived from larger clasts occur in samples where the amount of broken surfaces is greater than 35 percent of the surfaces (see samples at 120, 280-400, and 560-720 ft). Samples at 110, 160-240, 440, and $800 \mathrm{ft}$ have 30 percent or less fractured surfaces, and many fragments (as large as $5-8 \mathrm{~mm}$ ) are clasts with mostly original surfaces. One implication of the fewer fractured clasts and numerous original clasts is that the fragments (and clasts) came from pebbly sandstone or pebbly conglomerate. Based on the spacing of samples analyzed, the amounts of fragmentation of apparently large clasts, and the alternating nature of minimum clast 
sizes between 110 and $800 \mathrm{ft}$, there appear to be several fining upward cycles of coarser- and finer-grained conglomerate to pebbly sandstone.

There are a small number of rinds that occur in samples at 110, 120, 200, and $280 \mathrm{ft}$, and each of these depths coincides with a small "trough" in the resistivity log data. Rinds are not common in the cuttings samples at Fort Irwin, but if they formed in the unsaturated zone, then they are typically associated with pedogenic carbonate deposits, suggestive of being part of a sedimentary section. Samples at 110 and $120 \mathrm{ft}$ straddle a low resistivity trough that is about 10$\mathrm{ft}$ thick, and the samples at 200 and $280 \mathrm{ft}$ are in troughs that are about 2-4 ft-thick, respectively. Low resistivity values are typically attributed to silt- or clay-rich deposits, and in the Fort Irwin area the silt and especially clay can be original sedimentary grains, formed by pedogenic processes, or they can be altered from the original volcanic glass in the sedimentary rocks. So, these four samples contribute to the understanding of the lithostratigraphy and geophysical log data; however, they should not be overinterpreted and applied to all resistivity troughs.

There is one sample at $320 \mathrm{ft}$ that contains lithic-rich matrix coatings on lithic clasts. Although it might appear that this sample is an anomaly, it simply indicates that this deposit contains more detrital features than in the deposits above and below. The sample was among the first set of samples to be examined, and it was described during the time when there was no distinction between pumice-lithic-rich and lithic-rich coatings. Both of these lithic-rich subcategories indicate material was deposited from surficial processes that transported and deposited detrital grains, and the lithic-rich and pumice-rich deposits can occur in an alluvialfluvial facies within or outboard of a primary volcanic facies.

All samples below $110 \mathrm{ft}$ have tuffaceous coatings; however, the relative amounts of lithic-poor and lithic-bearing tuffaceous coatings varies. The samples from 200, 240, 320, 560, 640, and $800 \mathrm{ft}$ were examined during the period when there was no distinction between tuffaceous and lithic-bearing tuffaceous coatings, so these samples do not have the most detailed of observations to compare to the tuffaceous coatings of other samples. The lack of these more detailed descriptions does not influence the overall interpretation that these samples are from tuffaceous sedimentary rocks, and these additional details would only be needed if specific rock types were to be attributed to the samples.

Three pieces of core were collected at 260, 460, and $660 \mathrm{ft}$ (fig. 15), and all samples are volcaniclastic lithic-rich pebbly sandstone. At $260 \mathrm{ft}$, the rock at the top of the core has clasts up to about $5 \mathrm{~mm}$ in a tuffaceous fine-grained matrix, and the rock at the bottom of the core has clasts up to about $12 \mathrm{~mm}$ in a more lithic-rich fine-grained matrix. At $460 \mathrm{ft}$, core recovery was only 24 percent, and although there was part of a 3-4-cm thick, small pebbly sandstone near the base of the core, most of it consisted of individual clasts up to about $15 \mathrm{~mm}$ diameter, with one clast about $36 \mathrm{~mm}$ diameter, and with no appreciable amounts of matrix. At $660 \mathrm{ft}$, core recovery was only 43 percent, and consists of pebbly sandstone with clasts up to about $9 \mathrm{~mm}$ in a tuffaceous to lithic-bearing tuffaceous, fine-grained matrix.

\section{Summary of Lithostratigraphic Features and Units in Borehole NELT3}

In borehole NELT3, the combination of (1) the abundance of deposits with pebble and smaller clasts with interbedded coarse-grained deposits, and (2) the amount of rounding of clasts, are consistent with medial (or medial to distal) alluvial fan or fluvial deposits. These grain-size and textural features are consistent with the periodic influx of coarser- or finer-grained deposits resulting from the lateral migration of the primary channels across a fan, or as the coarser parts of a fan prograde farther into the basin and retrograde back towards the highlands. Alternatively, 
many of the rounded and well-rounded clasts might be recycled from previously deposited sediments (that is, the clasts are polycyclic), and they are simply incorporated into the otherwise finer grained sediment.

Although there are minor variations in the types of lithic clasts throughout the borehole (implying similar provenance and source areas), there appear to be differences in the coatings on lithic clasts and (by inference) the matrix materials of the sedimentary rocks above and below about $108 \mathrm{ft}$ depth, consistent with changes in geophysical log data. At depths less than $108 \mathrm{ft}$, most coatings are lithic rich (although many are rich in rounded pumice clasts) and indicate redeposited, epiclastic, and detrital sediments that had moderately developed grain-size sorting, such as in streams. At depths greater than $108 \mathrm{ft}$, most coatings are tuffaceous (both lithic-poor and lithic-bearing) and are indicative of sediment-laden flows where grain-size sorting is not very efficient. Examples of such deposits are pyroclastic flows or (more likely) debris flows redeposited shortly after a sequence of volcanic eruptions. Based on differences in components (more or less ash in the matrix) and depositional styles (more or less debris flow or stream deposits), this depth of $108 \mathrm{ft}$ is provisionally interpreted to approximate the contact of the inferred Quaternary to Pliocene(?) rocks and the inferred Miocene(?) rocks (table 3).

Borehole NELT3 was drilled in the medial to distal part of alluvial fans that have headwaters in the highland areas to the southwest (Pioneer Plateau) and west (Mars Hills). In the younger (Quaternary to Pliocene?) rocks, the types of pebble to cobble sandstone and conglomerate that are inferred from the cuttings in the borehole are consistent with this alluvial fan depositional environment. In the older (Miocene?) rocks, the lithic volcanic clasts, along with the mostly tuffaceous matrix in the deposits, are consistent with deposition in medial to distal alluvial fans or fluvial environments with source areas to the southwest (Pioneer Plateau), west (Mars Hills), or possibly north (the Garry Owen area). No obvious lava flows or primary pyroclastic flow or fallout tephra deposits were identified in NELT3, and this is consistent with a more clastic (alluvial fan or fluvial) sedimentary environment. The area near borehole NELT3 appears to represent a different environment of deposition (that is, medial to distal alluvial or fluvial fan) compared to sites such as (1) GOLD1 that represents a more proximal environment to eruptive centers and consists of more primary or minimally redeposited materials, or (2) NELT1 that represents more distal alluvial fan, fluvial, or lacustrine environments of deposition. In all of these boreholes and depositional environments, ash particles (whether as primary or redeposited material) appear to be important components in the Miocene(?) deposits.

\section{Lithostratigraphy in Boreholes NELT1, 2, 4, 5, 6, and 7}

Boreholes NELT1, NELT2, NELT4, NELT5, NELT6, and NELT7 were drilled in a variety of settings in the Nelson basin to explore the different geologic and hydrogeologic conditions within the basin (fig. 2). The main interest in detailed lithologic descriptions of cuttings in these boreholes was to evaluate the possibility of identifying the contact of the inferred Quaternary to Pliocene(?) rocks with the underlying inferred Miocene(?) rocks; therefore, most of the detailed descriptions are from the upper 200-400 ft of the boreholes. There are well construction diagrams, and lithologic shaker and sieve logs (including the rig lithology logs) for all the NELT-series boreholes; these document the conditions during drilling and descriptions of samples collected during drilling of the borehole (Kojs and others, 2014). The NELT-series boreholes were drilled using mud-rotary techniques and cuttings samples were collected from the shaker table in 10-ft intervals. As with NELT3, the cuttings were prepared with gentle washing to preserve the matrix and coatings on lithic clasts, and were described using 
the same criteria for identifying the components of (1) lithic type, (2) broken versus original surfaces on lithic fragments, (3) rims and rinds, and (4) lithic-rich coatings (including pumicerich, lithic-rich coatings) and lithic-poor and lithic-bearing tuffaceous coatings.

\section{Interpretations for Stratigraphy in NELT1}

Borehole NELT1 is midway across the basin in the topographic low just east of Nelson Lake, and about $1.6 \mathrm{~km}$ west of a low-relief drainage divide that separates a high-standing dacitic dome to the south from folded and faulted exposures of Miocene(?) sedimentary rocks at Crash Hill, near the Nelson Lake Fault (fig. 2). Cuttings samples were collected in 10-ft intervals (fig. 17), and three 3-ft-long core samples were collected at 200, 420, and $800 \mathrm{ft}$ (fig. 18) with 42, 42, and 36 percent core recovery, respectively (Kojs and others, 2014; Anthony Brown and Joseph Nawikas, USGS, written commun., 2011). Detailed component data for NELT1 are summarized in figure 19 and table 2.1.

\section{Young (Quaternary to Pliocene?) Alluvial Gravels (0-78 ft) in NELT1}

Samples from 50 and $70 \mathrm{ft}$ are similar in the types and amounts of fragments, the amounts of broken and original fragment surfaces, occurrence of rinds, and types and amounts of coatings. Most fragments are crystallized volcanic rocks with 4-5 percent partially to moderately lithified, fine- to medium-grained, lithic-rich sandstone (with visual estimates of porosity varying from $0-25$ percent) and at $70 \mathrm{ft}$ there is 1 percent fine- to medium-grained, lithic-crystal-pumicebearing tuff with fine-ash matrix. Both samples have 15 percent broken fragments with the largest fragments with all broken surfaces of $2 \times 3 \times 5 \mathrm{~mm}$ and $1 \times 5 \times 8 \mathrm{~mm}$ (at 50 and $70 \mathrm{ft}$, respectively). The largest original curviplanar surface on a broken fragment indicates an estimated maximum clast size between 15 and $30 \mathrm{~mm}$ in diameter. The largest clasts with all original surfaces are $3 \times 8 \times 10 \mathrm{~mm}$ and $2 \times 5 \times 9 \mathrm{~mm}$ (respectively), and both samples have clasts with mostly original surfaces that are less than $7-8 \mathrm{~mm}$. The coatings on lithic clasts have 1 percent lithic-poor tuffaceous matrix, 3-5 percent lithic-rich matrix, and 4 percent pumice-lithicrich matrix. The lithic-rich coatings are very similar to the lithic-rich sandstone fragments. In both samples there are 2 percent rinds, and several of the lithic-rich sedimentary fragments are cemented by calcite. 
A

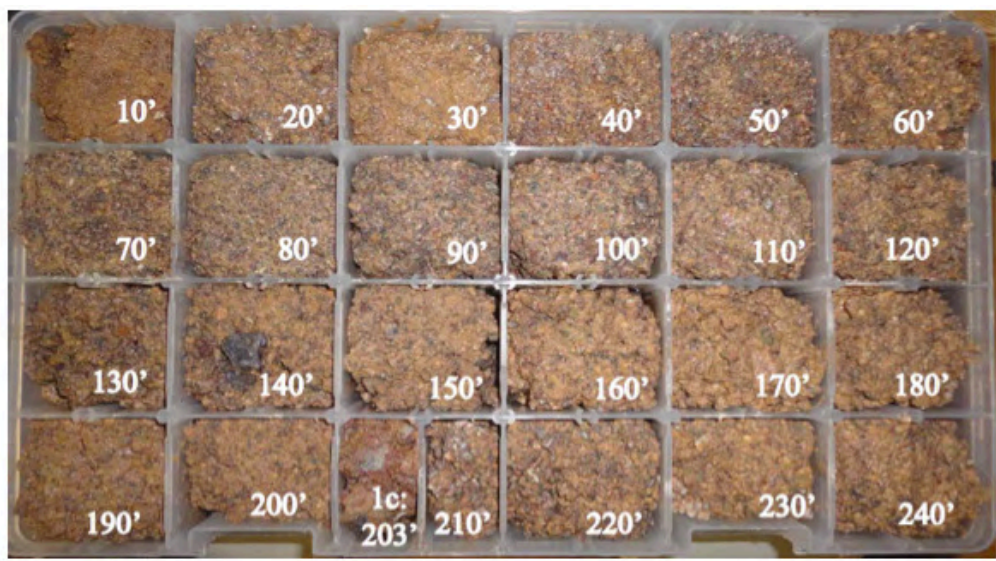

$\mathrm{B}$

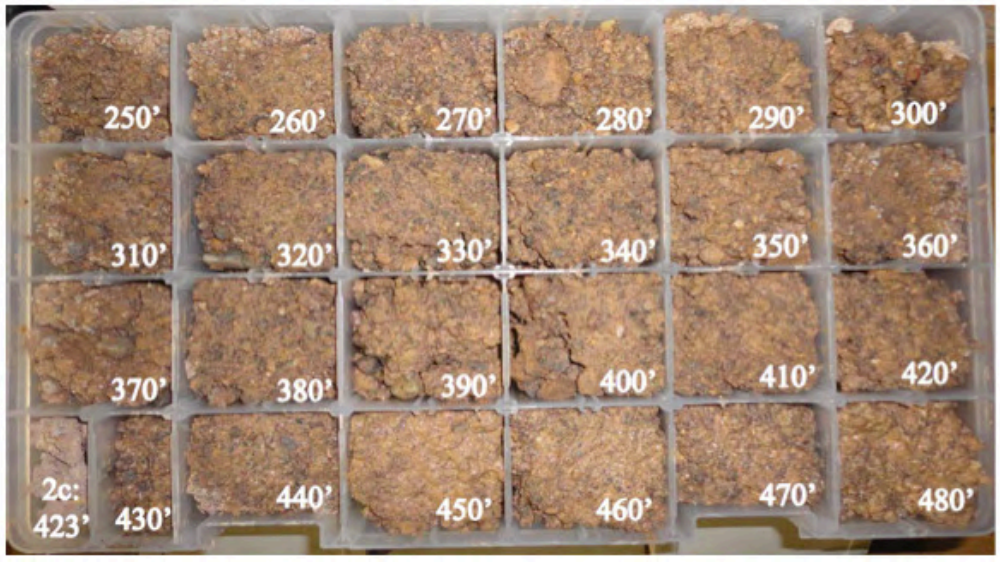

$\mathrm{C}$

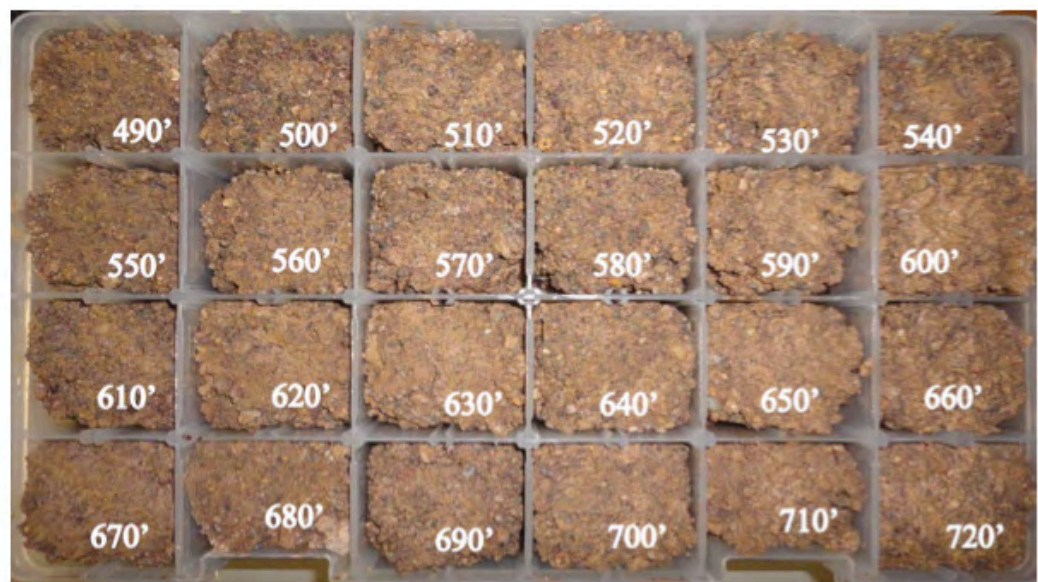

$\mathrm{D}$

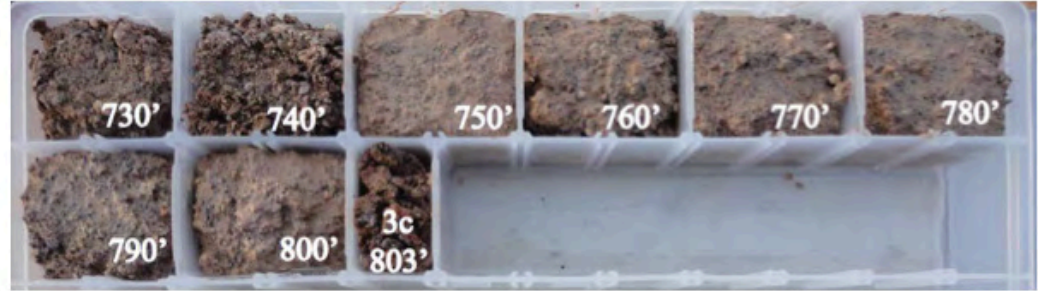

Figure 17. Photographs of cuttings from the shaker table for borehole NELT1 at Fort Irwin, California. A, samples from 10 to 240 feet (ft); $B$, samples from 250 to $480 \mathrm{ft}$; $C$, samples from 490 to $720 \mathrm{ft}$; , samples from 730 to $800 \mathrm{ft}$. Core samples at 203, 423, and $803 \mathrm{ft}$. A square chip cell is $50 \times 55$ millimeters. U.S. Geological Survey photographs by Joseph Nawikas. 


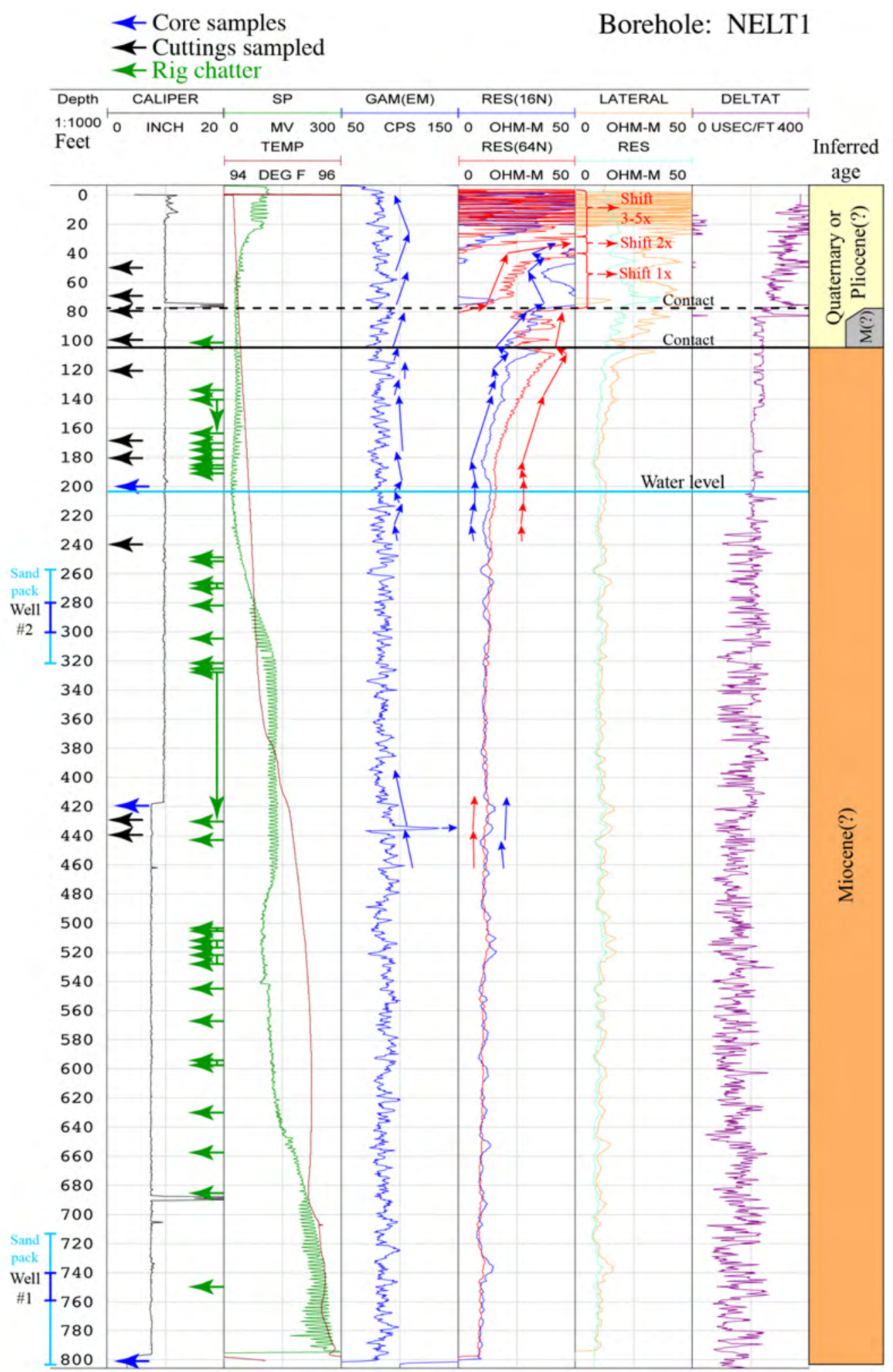

Figure 18. Graph showing locations of cuttings samples in borehole NELT1 at Fort Irwin, California, used for detailed examination compared to core, borehole geophysical logs, rig chatter, and locations of wells 1 and 2. Rig chatter from Anthony Brown (USGS, written commun., 2011). Borehole geophysical logs and depths to screened intervals from Kojs and others (2014). 


\section{Quaternary to Pliocene(?) or Miocene(?) Tuffaceous Sediments (78-104 ft) in NELT1}

Samples at 80 and $100 \mathrm{ft}$ differ from those at 50 and $70 \mathrm{ft}$, and have similarities to samples from 120 to $440 \mathrm{ft}$. The sample at $80 \mathrm{ft}$ has 89 percent crystallized (mostly lava flow) fragments, 1 percent mini-vesicular basaltic pumice, 8 percent very fine-grained, vitric, crystalbearing tuff and pumice fragments, and 2 percent lithic-rich sandstone with minor amounts of tuffaceous(?) matrix. The sample at $100 \mathrm{ft}$ has 98 percent crystallized (and a few vitric), mostly lava flow fragments, 1 percent mini-vesicular basaltic pumice, and 1 percent vitric, sparsely porphyritic pumice fragments. Coatings on lithic clasts at $80 \mathrm{ft}$ consist of 2 percent lithic-poor tuffaceous matrix and 5 percent crystal-bearing tuffaceous matrix (where the crystal-bearing matrix has 10 percent crystals and 2 percent lithic fragments). Also at $80 \mathrm{ft}$, the crystal-bearing tuff fragments are very similar to the lithic-poor and crystal-bearing tuffaceous coatings thereby reinforcing the correlation of fragmented rock matrix and coatings. Coatings on lithic clasts at $100 \mathrm{ft}$ consist of 4 percent lithic-poor tuffaceous matrix. The sample at $80 \mathrm{ft}$ has 10 percent broken fragments and the largest fragment with all broken surfaces is $2 \times 4 \times 8 \mathrm{~mm}$, and at $100 \mathrm{ft}$ there are 35 percent broken fragments and the largest fragment with all broken surfaces is $3 \times 9 \times 10 \mathrm{~mm}$. An estimate of the maximum clast size cannot be determined in either sample because the original surfaces on some broken fragments are planar and flat (that is, there is no arc from which to determine a radius). The largest fragment with all original surfaces is $2 \times 5 \times 8$ $\mathrm{mm}$ at $80 \mathrm{ft}$ and $3 \times 4 \times 11 \mathrm{~mm}$ at $100 \mathrm{ft}$, and most clasts less than 5-6 mm have mostly original surfaces.

\section{Miocene Tuffaceous Sediments (104-803 ft) in NELT1}

Samples from 120 to $440 \mathrm{ft}$ are similar in that they are mostly crystallized volcanic lithic fragments, and most coatings on lithic clasts are tuffaceous matrix. Based on slight variations in the lithostratigraphic components, the samples can be grouped into those from 120 to $180 \mathrm{ft}$, the sample from $240 \mathrm{ft}$, and samples from 430 and $440 \mathrm{ft}$. From 120 to $180 \mathrm{ft}$, there are 99-100 percent crystallized lava flow fragments. At $120 \mathrm{ft}$, there is one grain of granite that probably indicates a source from the Granite Mountains to the north (Miller and others, 2014). Coatings on lithic clasts vary from 2 to 6 percent, and typically they are tuffaceous, most are lithic poor, with minor amounts lithic bearing. The sample at 120 has 0.5 percent each of pumice-lithic-rich and lithic-rich coatings. Typically, in samples from 120 to $180 \mathrm{ft}$, the amounts of broken surfaces vary from 40 to 45 percent and the largest of the entirely broken surfaces vary from $2 \times 5 \times 8 \mathrm{~mm}$ to $5 \times 10 \times 15 \mathrm{~mm}$. Based on the curvature of original surfaces, the estimated maximum clast diameters in samples is $40-50 \mathrm{~mm}$ at $120 \mathrm{ft}$, and $20-30 \mathrm{~mm}$ at $180 \mathrm{ft}$. The largest clasts with entirely original surfaces vary from $3 \times 4 \times 6 \mathrm{~mm}$ to $5 \times 8 \times 11 \mathrm{~mm}$ with most clasts less than $6 \mathrm{~mm}$ having mostly original surfaces. For samples from 120 to $180 \mathrm{ft}$, the sizes for the broken fragments, original clasts, and estimated maximum original clast sizes increase with depth.

Compared to the other samples, the sample at $240 \mathrm{ft}$ has (1) a lower percentage of broken clasts, (2) slightly smaller broken and original fragments, but (3) larger maximum estimated clast size. Broken surfaces comprise 25 percent of the lithic fragments, and the maximum sized fragment with entirely broken surfaces is $5 \times 5 \times 6 \mathrm{~mm}$. Based on the curvature of an original surface on a broken fragment, the estimated maximum diameter is from 40 to $60 \mathrm{~mm}$. The largest clast with entirely original surfaces is $3 \times 6 \times 9 \mathrm{~mm}$ with most fragments less than $5 \mathrm{~mm}$ having mostly original surfaces.

The samples from 430 and $440 \mathrm{ft}$ were examined in order to better understand the changes in geophysical log values at $437 \mathrm{ft}$ (especially a sharp, narrow peak in gamma and a 
small increase in resistivity). In these samples, there are 99-100 percent crystallized lava flow fragments (there is one grain of granite at $440 \mathrm{ft}$ ). Coatings on lithic clasts are typically lithicpoor tuffaceous matrix that vary from 2 to 5 percent of the original surface, and at $430 \mathrm{ft}$, there are 0.5 percent each of lithic-rich and pumice-lithic rich coatings. For samples at both 430 and $440 \mathrm{ft}$, the amounts of broken surfaces vary from 40 to 50 percent, and the largest entirely broken surfaces vary from $2 \times 5 \times 15 \mathrm{~mm}$ to $3 \times 8 \times 14 \mathrm{~mm}$. The estimated maximum clast diameters cannot be estimated because the original surfaces on the broken fragments are too flat and planar. The largest clasts with entirely original surfaces vary from $4 \times 7 \times 13 \mathrm{~mm}$ to $7 \times 9 \times 14 \mathrm{~mm}$ with most clasts less than 8-9 mm having mostly original surfaces. The similarities in these components are consistent with the samples from different beds, but within an overall similar sedimentary sequence of pebbly sandstone with some component of a tuffaceous matrix. These samples do not provide any information regarding the variations in geophysical log values. The sharp peak in gamma-ray and small peak in resistivity at a depth of $435 \mathrm{ft}$ are speculated to result from a thin tephra bed that was not sampled by the 10-ft incremented cuttings samples.

\section{Correlations of Lithostratigraphic Features to Geophysical Data in NELT1}

In NELT1, for most of the borehole, the caliper values indicate very few irregularities in diameter; therefore, the geophysical log values are likely to be influenced by lithostratigraphic features (fig. 18). From 0 to $15 \mathrm{ft}$, the caliper log indicates a slightly enlarged borehole diameter that might affect geophysical values. Caliper values from 75 to $78 \mathrm{ft}$ indicate an enlargement of the borehole, and there are no comments in the rig lithology log about any differences in drilling conditions (Anthony Brown and Joseph Nawikas, USGS, written commun., 2011). It is likely that this enlargement of the borehole is near a contact between the moderately lithified, lithicrich sandstone at $70 \mathrm{ft}$ and the vitric tuffaceous rocks at $80 \mathrm{ft}$. Caliper values from 686 to $690 \mathrm{ft}$ indicate an enlargement of the borehole, and there was rig chatter at $684 \mathrm{ft}$ (Anthony Brown and Joseph Nawikas, USGS, written commun., 2011), but samples were not analyzed near this depth (which was too deep for the focus of this study).

Throughout NELT1, the spontaneous potential values have long wavelength variations that are similar to some other boreholes, but are not as detailed as in others. The spontaneous potential values might measure properties of the rocks, but in this borehole, they are gradational enough that they are not reflecting the detailed variations in the gamma and resistivity values. In the spontaneous potential values, there are very periodic, short wavelength variations (about 2 peaks per $5 \mathrm{ft}$ ) that might result from electrical interference during data collection (Keys and MacCary, 1971). Because gamma-ray and resistivity instruments are on the same tool string, similar short wavelength variations in these logs should be viewed with caution.

In NELT1, resistivity values generally decrease from 0 to $182 \mathrm{ft}$ with only small variations from 182 to $800 \mathrm{ft}$ (fig. 18). From 0 to $40 \mathrm{ft}$, there is a large decrease in resistivity, and from 40 to $182 \mathrm{ft}$, there is a generalized decrease. From 40 to $104 \mathrm{ft}$, the two resistivity logs have several changes in how much they decrease or increase in values, and these cycles probably result from lithostratigraphic differences in the rocks. The decrease in resistivity from 0 to $40 \mathrm{ft}$ probably results from vegetative (evapotranspiration) and barometric drying in the near surface parts of the unsaturated zone, and from 40 to $182 \mathrm{ft}$, the general decrease in resistivity results from barometric pumping and drying (Flint and others, 2001; Flint and others, 2002). The water level in well \#1 is at $207 \mathrm{ft}$, and in well \#2 it is at $203 \mathrm{ft}$ (Kjos and others, 2014). These water levels occur within a broad (48 ft long), small amplitude (5 ohm-meter [ohm-m]), resistivity compound cycle that spans several gamma cycles (fig. 18 with only the water level at $203 \mathrm{ft}$ 
displayed). At this depth. the resistivity and gamma cycles are probably lithostratigraphically controlled, and the water levels do not have a direct influence on resistivity values. In the saturated zone, the amount of variation in resistivity values is small; however, in detail, cycles in resistivity can be identified and probably relate to variations in lithostratigraphic and hydrogeologic properties of the rocks.

In NELT1, gamma and resistivity values have moderate amounts of variations that form numerous cycles from 0 to $238 \mathrm{ft}$ (fig. 18). From a stratigraphic point of view (using up-borehole trends), these cycles consist of waveforms with (1) similar amplitude and wavelengths, (2) increasing amplitude and (or) wavelengths, (3) decreasing amplitude and (or) wavelengths, and (4) with any of these waveform patterns, the mean values through the cycle can be the same, increase, or decrease (fig. 18). Cycles are typically 5-40 ft thick. These waveforms and cycles are indicative of lithostratigraphic and hydrogeologic properties.

The upper and lower contacts of the waveforms in the gamma and two resistivity log values can coincide, but because these logs measure different properties, a single bed could have as many as six waveform contacts within the bed (2 gamma, 2 RES(64N), and 2 RES(16N)). At this stage of the study, the cycles in the three logs are identified empirically, but they can also have tops and bottoms that differ or coincide. There are a number of depths where two or more of the geophysical logs show changes in values (or in the characteristics in the values) that might correlate to changes in lithostratigraphic features. These depths include, but are not limited to, 52, 78, 104, 137, 196, and $237 \mathrm{ft}$. Compared to the cuttings at $70 \mathrm{ft}$, the cuttings at $80 \mathrm{ft}$ have an increase in tuffaceous sedimentary fragments and an increase in tuffaceous coatings. At $78 \mathrm{ft}$, gamma values have similar trending cycles of increased mean values, but the details of the wavelength and amplitude differ. Also at $78 \mathrm{ft}$, there is a reversal in resistivity cycles within an overall increasing trend. At $100 \mathrm{ft}$ and $120 \mathrm{ft}$, the lithologic components of cuttings samples are similar, but there is a slight increase in tuffaceous coating at $120 \mathrm{ft}$. At $104 \mathrm{ft}$, the gamma cycles change in characteristics including length of the cycle, wavelengths and amplitudes, and mean values of the waveforms. Also at $104 \mathrm{ft}$, both resistivity logs have up-hole mostly gradational increases in values; however, above $104 \mathrm{ft}$ the resistivity values have a sharp decrease and begin the up-hole cycles (of which $78 \mathrm{ft}$ is a part) of increasingly larger wavelengths, amplitudes, and mean values of waveforms and cycles.

The geophysical logs from 238 to $800 \mathrm{ft}$ were not examined systematically, but continue to have characteristics of waveforms and cycles that are indicative of sedimentary rock sequences (fig. 18). Gamma values continue with similar variations as in the unsaturated zone. Resistivity only has small variations in the waveforms and cycles that are diminished by the abundance of water in the saturated zone.

There is a large increase (peak) in gamma and moderately sized peak in resistivity at 435 $\mathrm{ft}$, and another smaller peak in gamma and resistivity at $420 \mathrm{ft}$ (fig. 18). Gamma values are typically influenced by the amounts of K, U, and Th (Keys and MacCary, 1971; Keys, 1990), and these elements are more abundant in rhyolitic rocks compared to more mafic rocks including andesitic and basaltic rocks, so a sharp narrow peak in gamma could indicate a rhyolitic tephra bed or a rhyolite-clast sandstone or conglomerate. The cuttings samples at 430 and $440 \mathrm{ft}$ provide no direct evidence for such (rhyolitic) tephra beds. The core at $420 \mathrm{ft}$ is from a pebbly tuffaceous sandstone that has matrix is likely clay-altered tuffaceous material, some white pumice clasts, and darker colored crystallized and clay-altered clasts that more mafic (probably andesite or dacite). This tuffaceous sandstone is a reasonable explanation for the smaller gamma and moderate-sized resistivity peak at $420 \mathrm{ft}$, but it does not provide any information to explain the 
sharp narrow gamma peak at $435 \mathrm{ft}$. For comparison, although borehole BLA5 was not studied as part of this investigation, there is a sharp, moderately large, spike in gamma values at a depth of $148 \mathrm{ft}$ that correlates to a short segment of cuttings containing fragments of white, very finegrained, possible tephra (Anthony Brown, USGS, written commun., 2012). A sample of cuttings from $148 \mathrm{ft}$ was collected from borehole BLA5B (which is only $4 \mathrm{~m}$ from BLA5), and petrographic analysis of fragments confirms that along with small fragments of feldspar and amphibole, some grains appear to be glass shards.

\section{Probably Quaternary to Pliocene(?)}

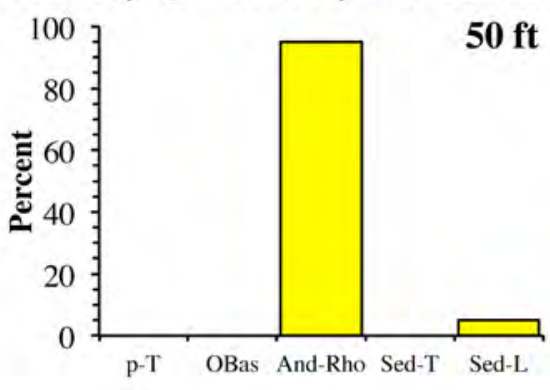

Some fragments are polycyclic clasts.

Some Sed-L fragments are cemented by calcite.

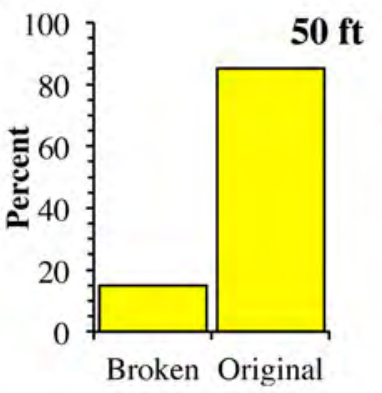

Cross hatched Coat- $\mathrm{L}$ is the percent of the pumice-lithic-rich matrix.

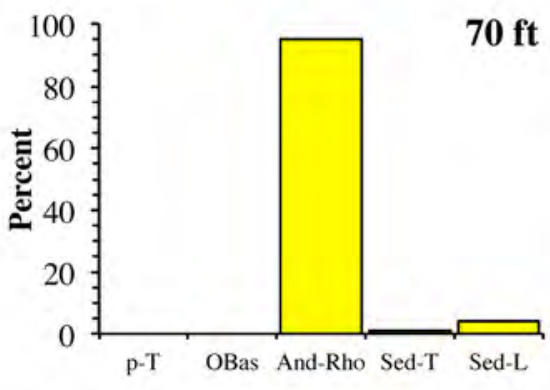

Some fragments might be polycyclic clasts.

Sed-T is fine-to-medium-grained, lithic and crystalbearing tuff (few pumice clasts) in fine-ash matrix.

Sed-L is partially to moderately lithified, lithic-rich to pumice-lithic-rich sandstone.

Some Sed-L fragments are cemented by calcite.
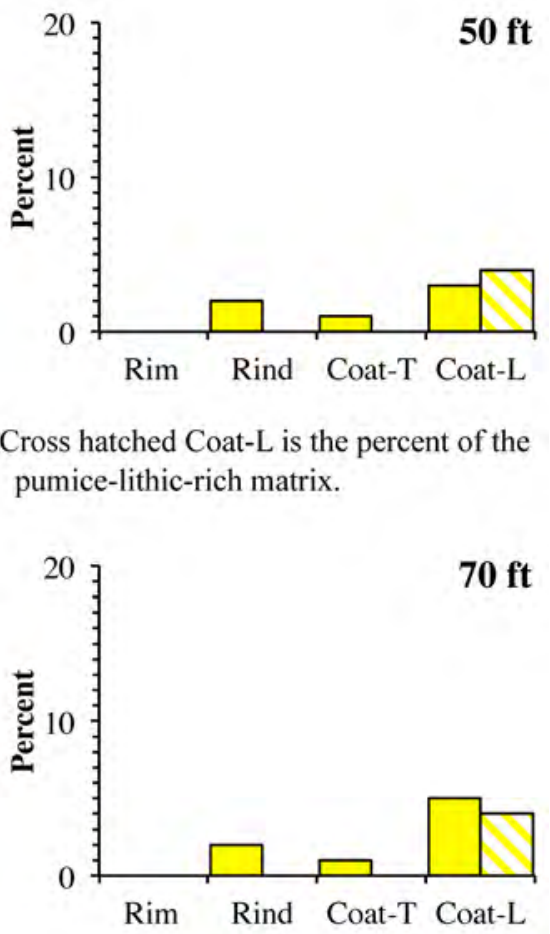

Coat- $\mathrm{T}$ is very similar to Sed-T.

Cross hatched Coat- $\mathrm{L}$ is the percent of the pumice-lithic-rich matrix.

Both Coat-L are very similat to Sed-L.

Figure 19. Bar graphs of components of cuttings samples in borehole NELT1 at Fort Irwin, California. Lithostratigraphic units: yellow, lithic-rich sediment, probably Quaternary or Pliocene(?); gray, lithic-rich sediment with tuffaceous matrix, probably either Quaternary or Pliocene(?) or Miocene(?); orange, tuffaceous sediment, probably Miocene(?). Components: p-T, Pre-Tertiary; Obas, porphyritic olivine basalt; And-Rho, andesite to rhyolite; Sed-T, tuffaceous sedimentary rocks, Sed-L, lithic-rich sedimentary rocks; Broken, broken surfaces; Original, original surfaces; Rim, thin layer of crystallization in volcanic rock along a cooling fracture; Rind, calcite, opal, or chalcedony deposits on a lithic clast; Coat-T, tuffaceous coatings; Coat-L, lithic-rich coatings. 


\section{Probably Quaternary to Pliocene(?) or Miocene(?)}

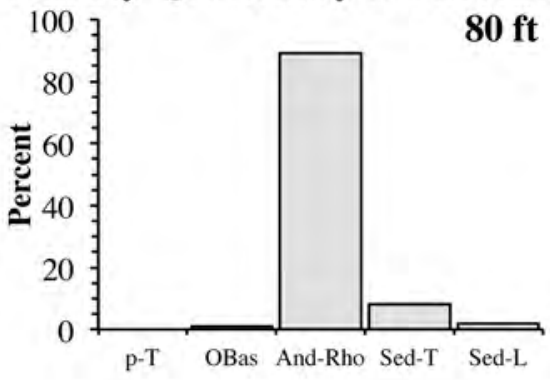

Some fragments are polycyclic clasts.

OBas is one clast of mini-vesicle basalt pumice.

Sed-T are pieces of vitric, fine-grained, crystal-bearing tuff includes mini-vesicular, porphyritic, pumice fragments (some cemented by calcite(?).

Sed-L is lithic-rich sandstone with minor, white, tuffaceous(?) matrix (some cemented by calcite?).
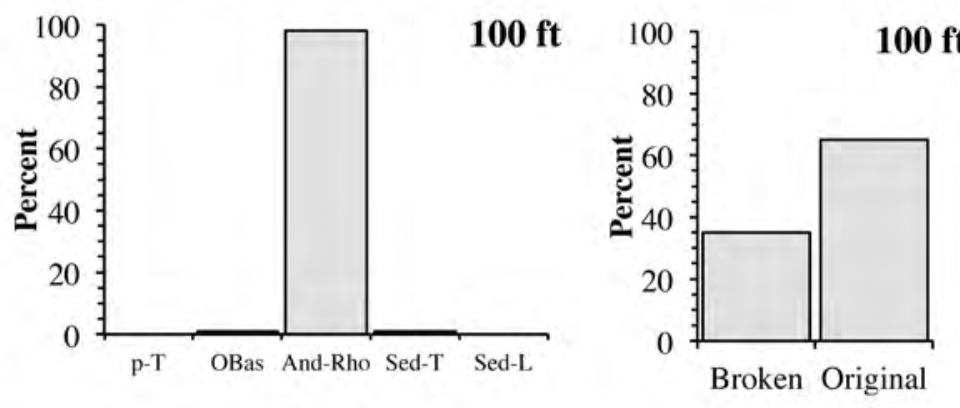

Some fragments are polycyclic clasts.

OBas is one clast of mini-vesicle basalt pumice.

Sed-T are pieces of vitric, sparsely porphyritic

mini-vesicular pumice fragments

(slightly rounded during drilling?)

\section{Probably Miocene(?)}
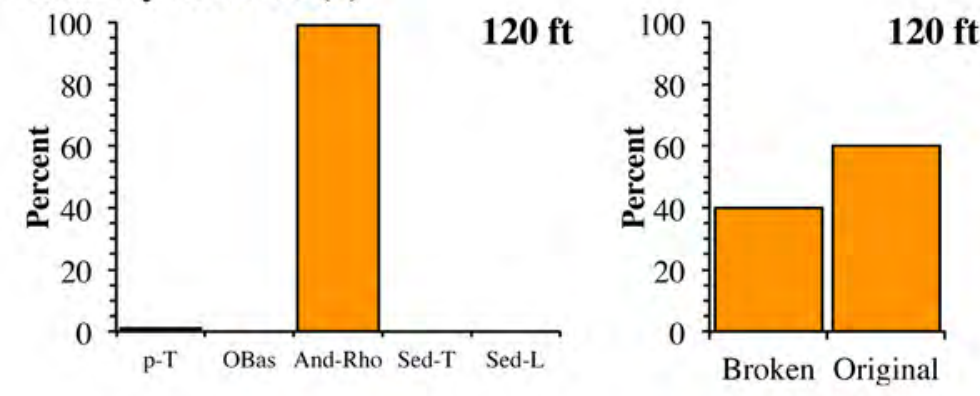

Some fragments are polycyclic clasts.

$\mathrm{p}-\mathrm{T}$ is one granitic clast.

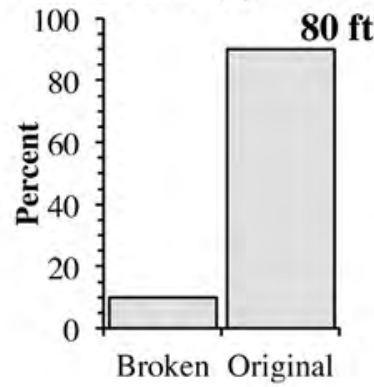

Cross hatched Coat- $T$ is the percent of the lithic-bearing tuffaceous matrix.

Both Coat- $T$ is very similar to Sed-T.

$80 \mathrm{ft}$

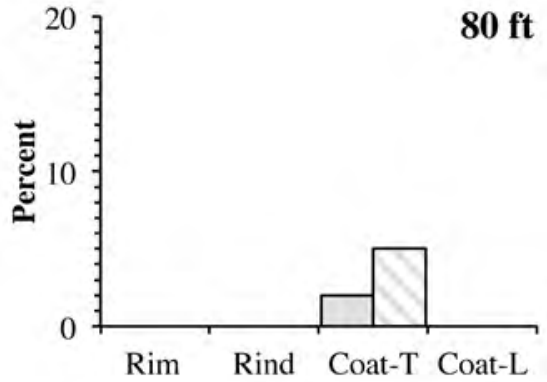

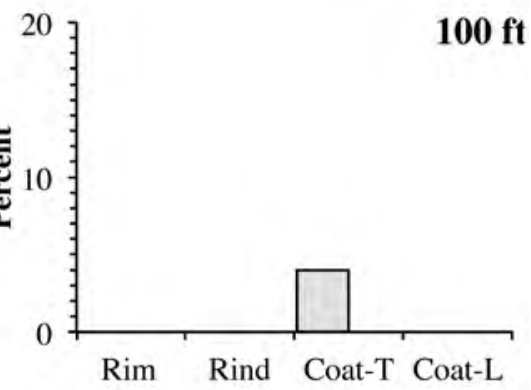



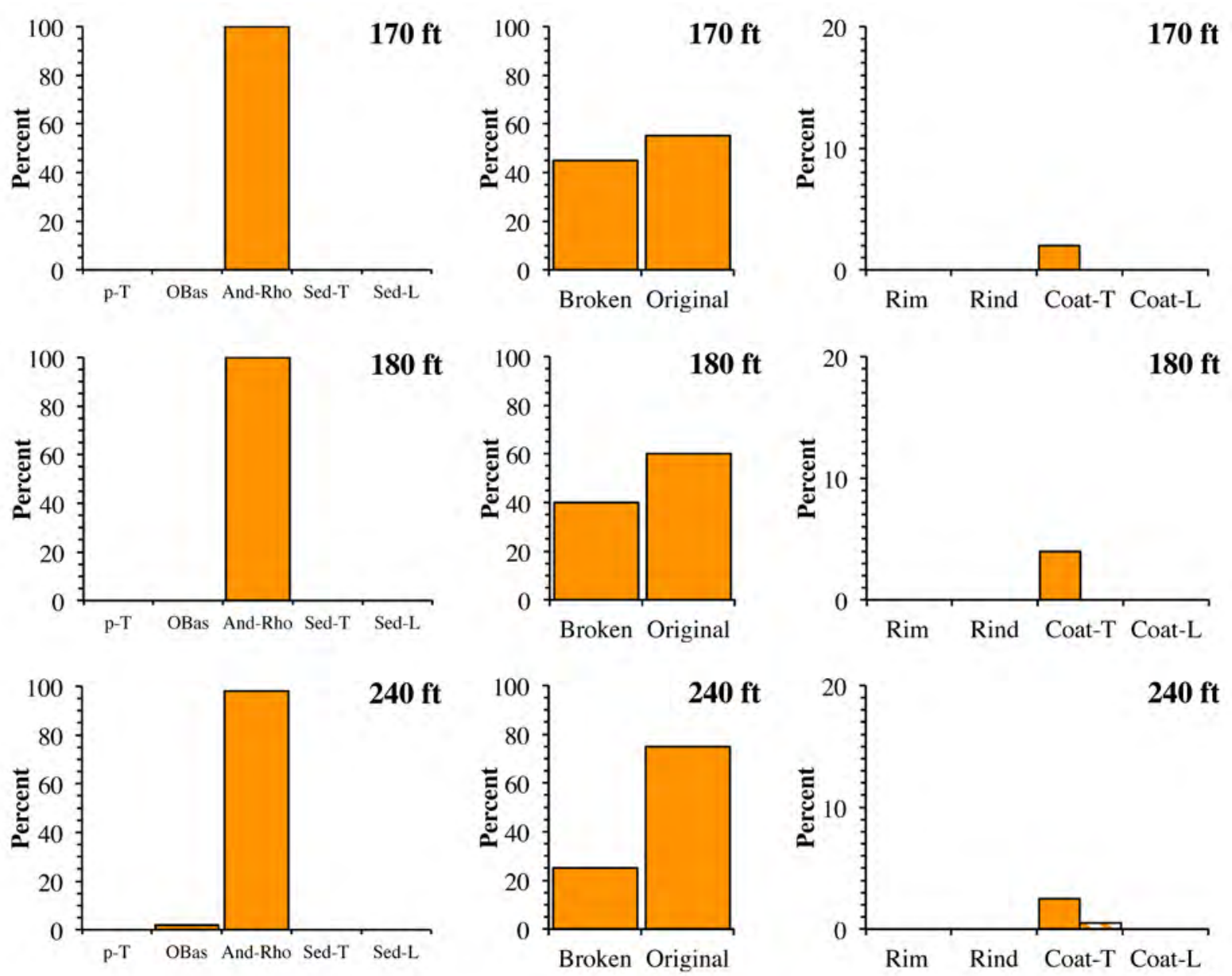

OBas is a fine-grained sparsely phyric andesitic (?) basalt.
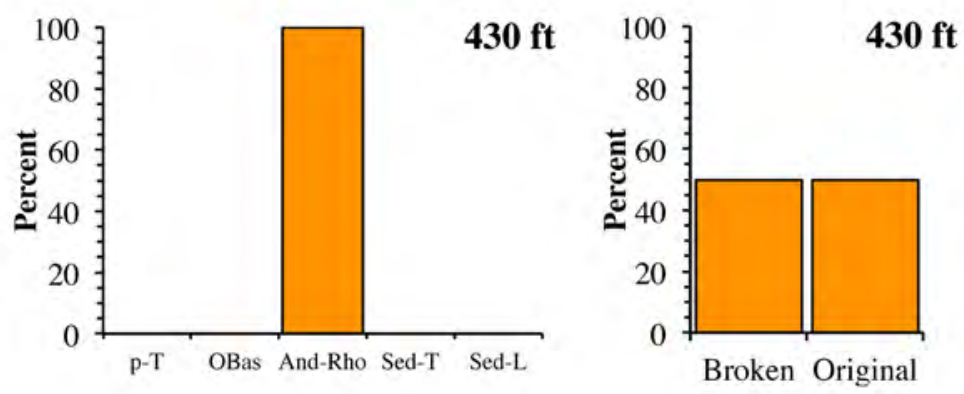

Cross hatched Coat- $\mathrm{T}$ is the percent of the lithic-bearing tuffaceous matrix.

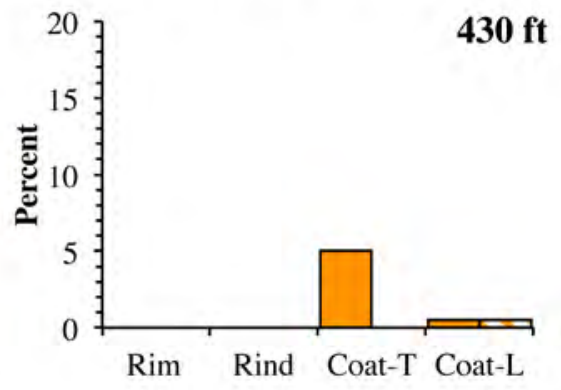

Cross hatched Coat- $\mathrm{L}$ is the percent of the pumice-lithic-rich matrix.

Figure 19.-Continued 

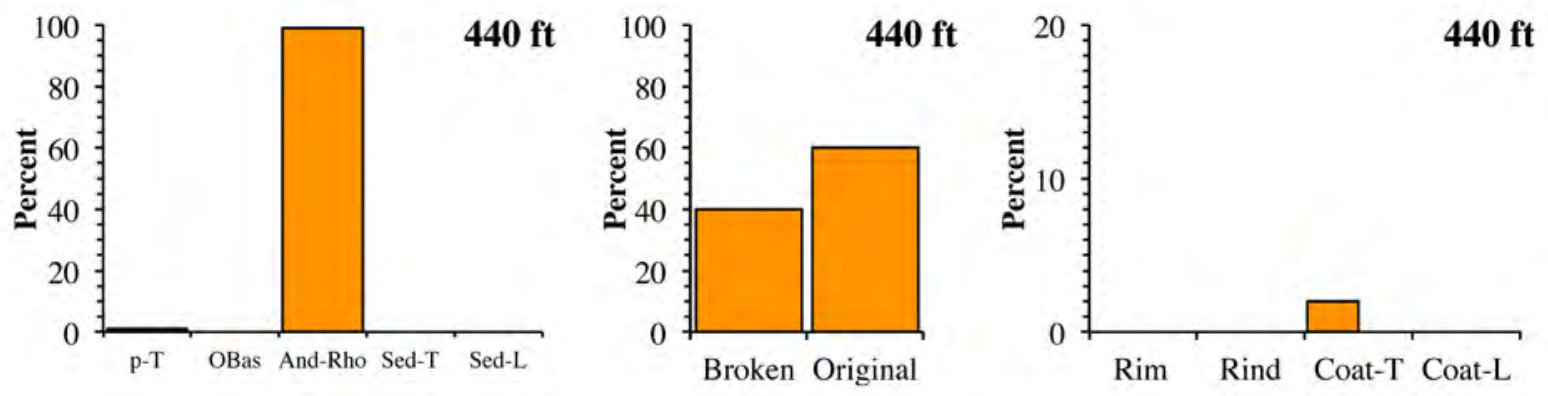

$\mathrm{p}-\mathrm{T}$ is one granitic clast.

Figure 19.-Continued

Near borehole NELT1, there are two TEM soundings, NL3 and NL7. NL3 is 733 m west of the borehole, and NL7 is $2.1 \mathrm{~km}$ east of the borehole (Burgess and Bedrosian, 2014; fig. 2). Using the best-fit minimum (four) layer model and the best-fit smooth inverse model, NL3 has a moderately sharp decrease in resistivity at $128 \mathrm{ft}$. Using these same types of models, NL7 has a small and gradational decrease at $105 \mathrm{ft}$. A rigorous correlation, including trying to determine the apparent dips of stratigraphic units between the borehole and TEM sounds, has not been made. However, the models for both sounding sites appear to be representing the resistivity in the borehole. For example, the peak in RES(16N) from 55 to $80 \mathrm{ft}$ and break in slope of the RES(64N) values about $80 \mathrm{ft}$, and the relatively sharp decrease in RES(16N) from 104 to $120 \mathrm{ft}$ with another break in slope at $140 \mathrm{ft}$. Below about $250 \mathrm{ft}$, the models have a little more variation in resistivity than what is in the borehole.

\section{Summary of Lithostratigraphic Features and Units in Borehole NELT1}

For most of the borehole, the cuttings are greater than 95 percent crystallized volcanic (typically lava flow) fragments with very few fragments of the host sedimentary rock (especially the matrix), and typically coatings on lithic clasts form less than 10 percent; therefore, it is very difficult to infer characteristics of the drilled (host) sedimentary rock. This lack of fragments of the host sedimentary rock (or the matrix) is consistent with the matrix being relatively nonlithified and mechanically weak, such that it is disaggregated during drilling. Detailed lithostratigraphic components on cuttings and geophysical log data are consistent with three groups of sedimentary rocks in borehole NELT1 from 0 to $78 \mathrm{ft}, 78$ to $104 \mathrm{ft}$, and 104 to $803 \mathrm{ft}$. Based on the variations in lithostratigraphic features and geophysical log data, there appear to be significant changes across the contacts at 78 and $104 \mathrm{ft}$.

From 0 to $78 \mathrm{ft}$, the sedimentary rocks are probably pebbly sandstone with epiclastic and detrital, lithic-rich to tuffaceous or pumice-rich, sandstone matrix. Samples from 50 and $70 \mathrm{ft}$ have rinds and calcite cemented sandstone fragments that are consistent with deposition of the calcite in the shallow unsaturated zone or near the base of a valley-filling sequence that developed on an unconformity. These rocks are inferred to have been deposited during the Quaternary to Pliocene(?) (table 3).

From 78 to $104 \mathrm{ft}$, the sedimentary rocks are probably pebbly sandstone with tuffaceous matrix and are possibly interstratified with vitric (to locally and incipiently altered), crystalbearing, pumiceous tuff. There are minor amounts of fragments in the sample at $80 \mathrm{ft}$ that have been partially cemented by calcite. These minor calcite-cemented deposits are consistent with the calcite being (1) pedogenic deposits formed near a stable geomorphic surface, or (2) deposited 
just below an unconformity that formed a lithostratigraphic but "seeping" hydrogeologic barrier resulting in partial ponding of groundwater or water flowing through the unsaturated zone (Neymark and others, 2007; Buesch, unpublished data). The sedimentary rocks from 78 to $104 \mathrm{ft}$ are inferred to have been deposited during the early part of the Quaternary-Pliocene(?) or the later part of the Miocene(?); however, there is great uncertainty in this inferred age (table 3). Both depths have changes in lithostratigraphic components and gamma and resistivity values and cycles; however, the changes at $104 \mathrm{ft}$ appear to separate the section above and below that depth a little more than the changes at $78 \mathrm{ft}$. If enough fragments containing glass and minerals in the tuffaceous rocks can be collected from the cuttings, these samples might be usable for tephrostratigraphic and tephrochronologic evaluations.

From 104 to $440 \mathrm{ft}$ (the deepest samples examined), the sedimentary rocks are probably pebbly sandstone to conglomerate with tuffaceous (and some detrital) matrix. Based on variations in the components such as inferred (and estimated) grain or clast sizes, the amounts of rig chatter, and possible cyclic variations in geophysical logs, there might be several 10-50-ft thick lithostratigraphic sequences in the section. Based on cursory evaluation of deeper cuttings, core, and geophysical log data, the sedimentary section appears to be similar from $440 \mathrm{ft}$ to the bottom of the borehole at $803 \mathrm{ft}$. These typically tuffaceous sedimentary rocks are inferred to have been deposited during the "synvolcanic" sequences that are probably related to the Miocene age Eagle Crags volcanic field as the nearest source for the tuffaceous material, or other mostly silicic volcanic fields in the Mojave region for some of the fallout tephra deposits (table 3).

\section{Interpretations for Stratigraphy in NELT2}

Borehole NELT2 is located about midway across the basin in a topographic low, $3.1 \mathrm{~km}$ east of a low-relief drainage divide, between a high-standing dacitic dome to the south and folded and faulted exposures of Miocene(?) sedimentary rocks at Crash Hill (Miller and others, 2014; Buesch and others, 2018). This low-relief drainage divide forms part of the western edge of the geomorphic Bicycle Lake basin. Cuttings samples were collected from the shaker table in 10 -ft intervals (fig. 20), and three 5-ft-long core samples were collected at 200, 400, and $720 \mathrm{ft}$ with percent core recovery of 100, 39, and 22 percent, respectively (Kojs and others, 2014; fig. 21). Detailed component data for NELT2 are summarized in figure 22. The following descriptions of lithostratigraphy are organized and based on cuttings and core, and the main change in stratigraphic characteristics occurs at a depth of about $170 \mathrm{ft}$, but there are detectable differences between the samples at 60-120 ft. At the end of the section, the addition of geophysical log data and correlations to lithostratigraphic features enables the refinement of the borehole stratigraphy.

\section{Lithic and Tuffaceous Alluvial Sandstone and Gravels (0-170 ft) in NELT2}

As a general overview, cuttings samples from 10 to $170 \mathrm{ft}$ have similar appearances and are mostly lithic clasts of various sizes (fig. 20). Detailed examination of samples at 60,120 , and $160 \mathrm{ft}$ indicate they are mostly (99-100 percent) clasts of crystallized lava flows (fig. 22). There are a few ( $0-1$ percent) grains of medium-grained, moderately well-sorted, crystal-lithic sandstone with tuffaceous matrix or partially lithified, slightly altered, crystal-lithic tuff. The crystal-lithic tuff fragments were probably eroded from the older and altered Miocene section; however, it is possible that the crystal-lithic sandstone represents part of the matrix for the drilled host rock. The interpretation of these relations is that the matrix in the sedimentary section (for the most part) is very poorly lithified, and simply disaggregates during drilling. 
A

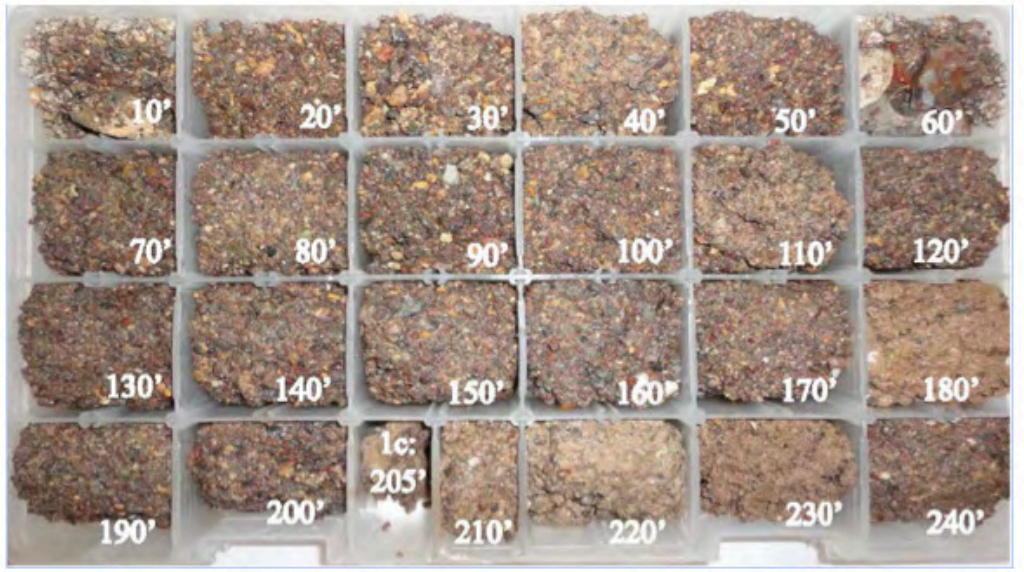

B

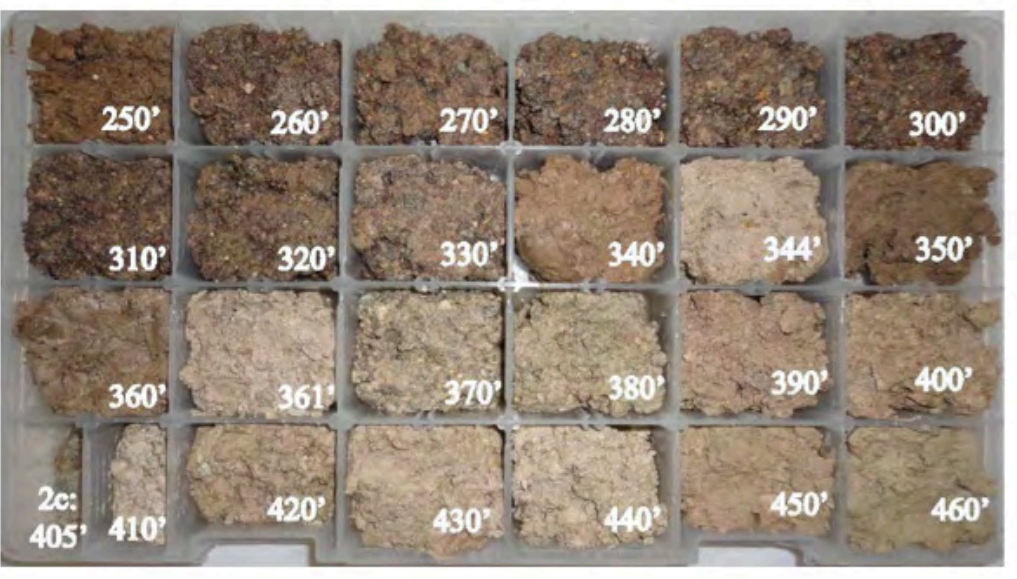

$\mathrm{C}$

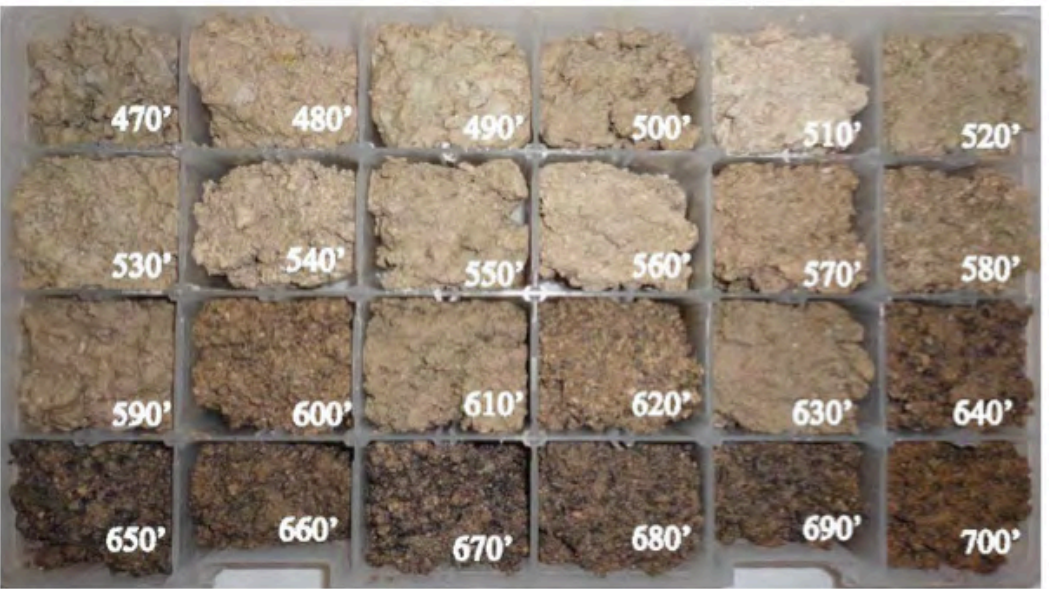

D

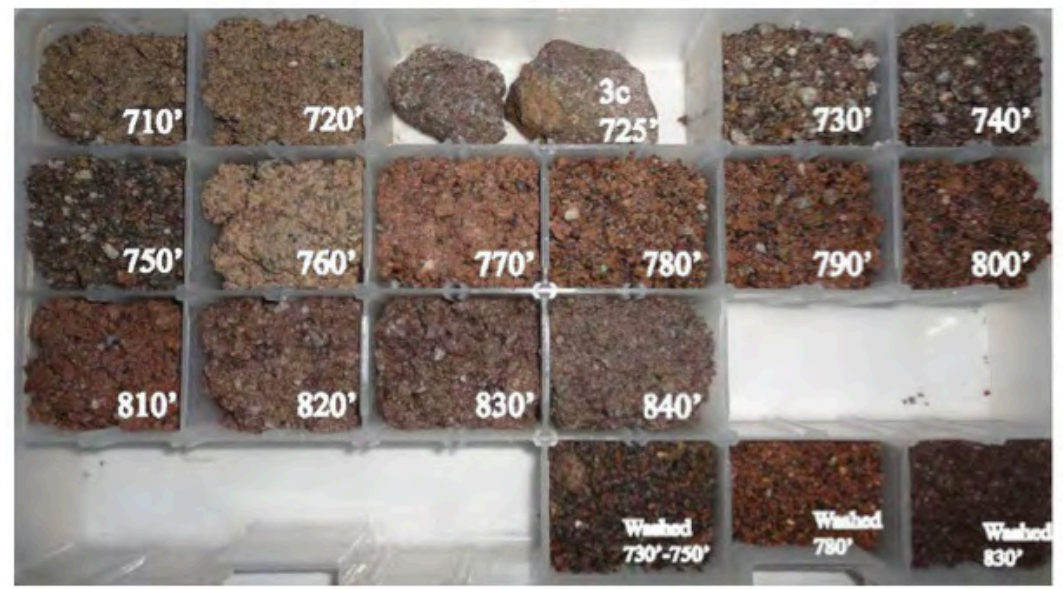

Figure 20. Photographs of cuttings from the shaker table for borehole NELT2 at Fort Irwin, California. A, samples from 10 to 240 feet (ft); $B$, samples from 250 to $460 \mathrm{ft}$; $C$, samples from 470 to $700 \mathrm{ft}$; $D$, samples from 710 to $840 \mathrm{ft}$. Core samples at 205, 503, and $885 \mathrm{ft}$. Samples at 360 , 380,780 , and $800 \mathrm{ft}$ have washed split samples. A square chip cell is $50 \times 55$ millimeters. U.S. Geological Survey photographs by Anthony Brown. 


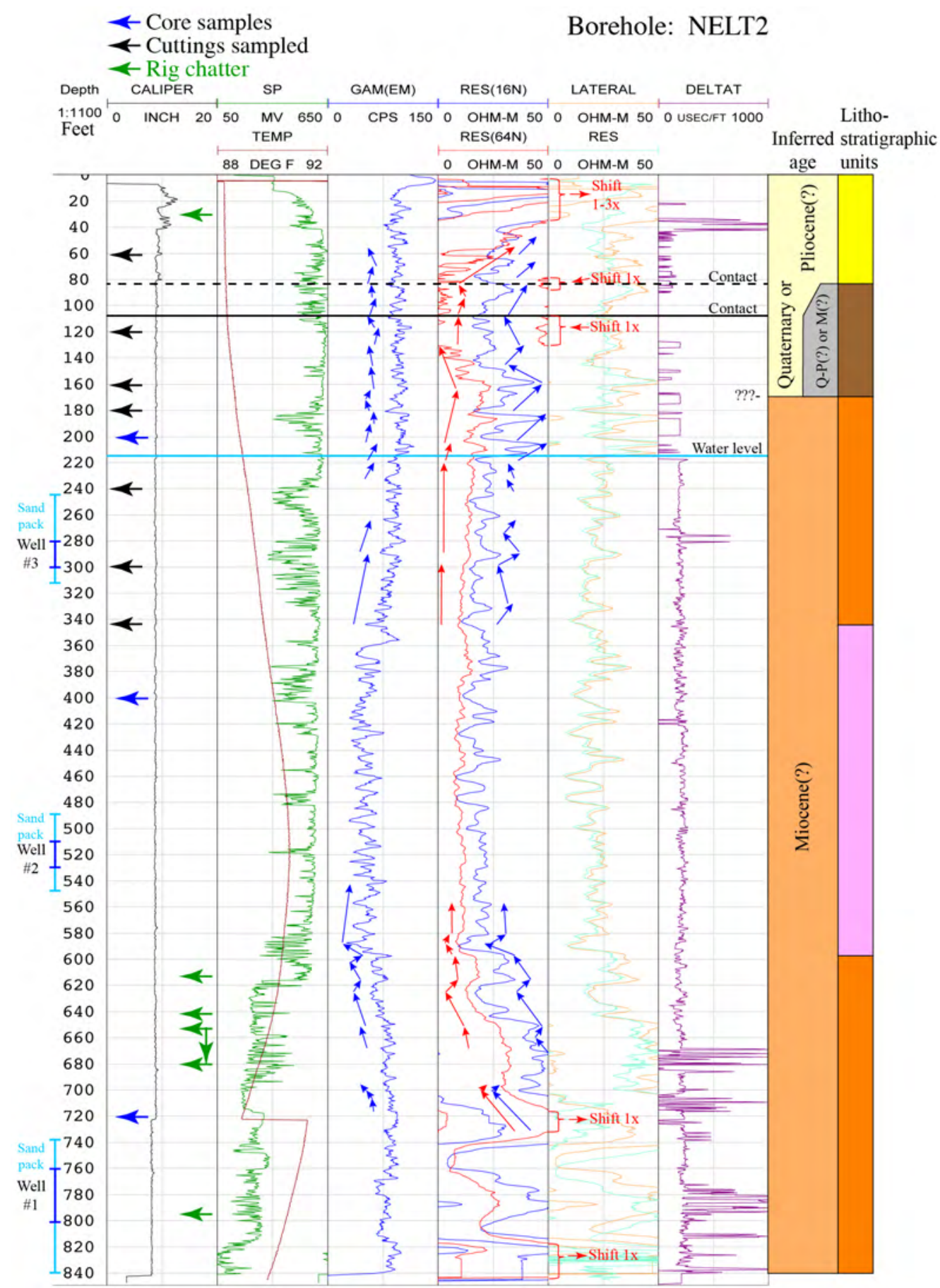

Figure 21. Graph showing locations of cuttings samples in borehole NELT2 at Fort Irwin, California, used for detailed examination compared to core, borehole geophysical logs, rig chatter, and wells 1, 2, and 3.

Rig chatter from Anthony Brown (USGS, written commun., 2011). Borehole geophysical logs and depths to screened intervals from Kojs and others (2014). Lithostratigraphic units: yellow, epiclastic, detrital (bedrockvolcanic-lithic) sandstone and conglomerate; brown, epiclastic, volcanic-lithic ( \pm bedrock-lithic), sandstone and conglomerate with tuffaceous-pumiceous(?) matrix; orange, volcaniclastic, lithic to lithic-rich, sedimentary rocks with tuffaceous ( \pm pumiceous) matrix; pink, tuffaceous (locally lithic-rich) sandstone and primary pyroclastic deposits). 
Based on detailed examination of cuttings from 60, 120, and $160 \mathrm{ft}$, the ratio of fragments with original surfaces to broken surfaces indicates that most cuttings fragments are plucked from the host rock; however, all samples have at least some fragments large enough to be broken during drilling (fig. 22). Broken fragments range from 10 to 15 percent of the lithic fragments. The largest broken surface at $60 \mathrm{ft}$ is $12 \times 16 \mathrm{~mm}$, the largest fragment with mostly broken surfaces at $120 \mathrm{ft}$ is $3 \times 5 \times 8 \mathrm{~mm}$, and the largest fragment with mostly broken surfaces at $160 \mathrm{ft}$ is $5 \times 15 \times 17 \mathrm{~mm}$. In all these samples, sizes of the largest clast cannot be determined. Clasts with mostly original surfaces vary from 85 to 90 percent. At $60 \mathrm{ft}$, the largest clast with all original surfaces is $12 \times 12 \times 22 \mathrm{~mm}$, and most grains less than $15 \mathrm{~mm}$ have many (to all) original surfaces. At 120 and $160 \mathrm{ft}$, the largest clasts with all original surfaces are $4 \times 5 \times 8 \mathrm{~mm}$ and $4 \times 5 \times 6 \mathrm{~mm}$, respectively, and most grains less than $5 \mathrm{~mm}$ have mostly original surfaces.

\section{Probably Quaternary to Pliocene(?)}
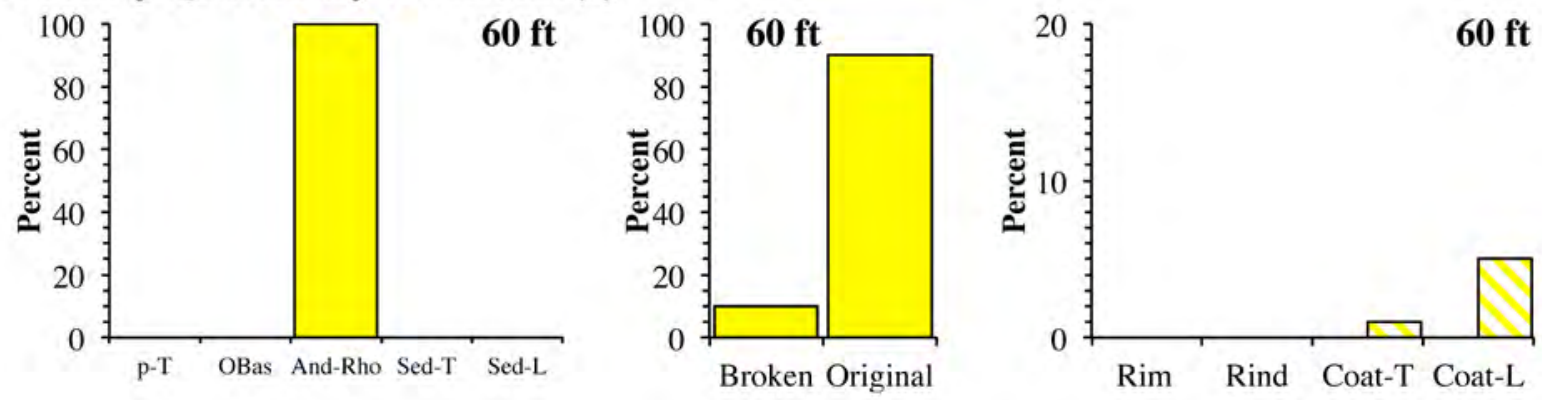

Cross hatched Coat-T is the percent of the lithic-bearing tuffaceous matrix.

Cross hatched Coat- $\mathrm{L}$ is the percent of the pumice-lithic-rich matrix.

\section{Probably Quaternary to Pliocene(?) or Miocene(?)}

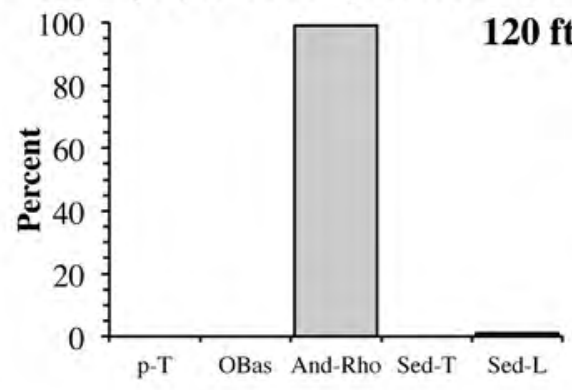

Sed- $\mathrm{L}$ is medium-grained, crystal-lithic sandstone with tuffaceous matrix.

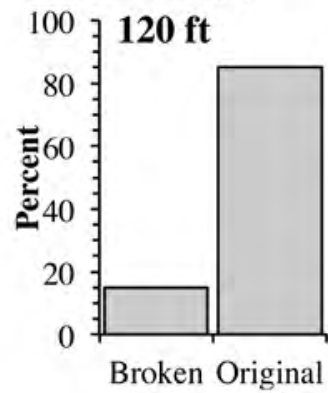

\footnotetext{
Cross hatched Coat- $\mathrm{T}$ is the percent of the lithic-bearing tuffaceous matrix.

Cross hatched Coat- $\mathrm{L}$ is the percent of the pumice-lithic-rich matrix.
}

Figure 22. Bar graphs of components of cuttings samples in borehole NELT2 at Fort Irwin, California. Lithostratigraphic units: yellow, lithic-rich sediment, probably Quaternary or Pliocene(?); gray, lithic-rich sediment with tuffaceous matrix, probably either Quaternary or Pliocene(?) or Miocene(?); orange, tuffaceous sediment, probably Miocene(?). Components: $\mathrm{p}$-T, pre-Tertiary; Obas, porphyritic olivine basalt; And-Rho, andesite to rhyolite; Sed-T, tuffaceous sedimentary rocks, Sed-L, lithic-rich sedimentary rocks; Broken, broken surfaces; Original, original surfaces; Rim, thin layer of crystallization in volcanic rock along a cooling fracture; Rind, calcite, opal, or chalcedony deposits on a lithic clast; Coat-T, tuffaceous coatings; Coat-L, lithic-rich coatings. 


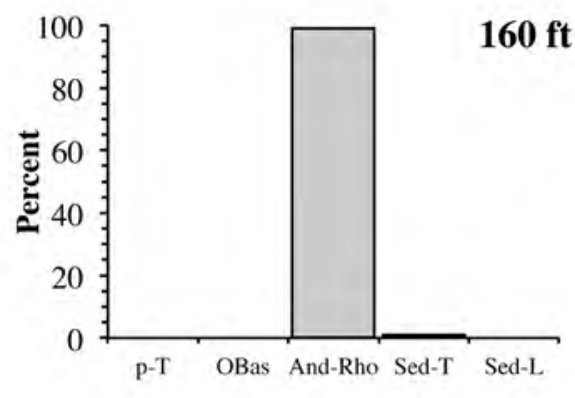

Sed-T is $1 \%$ (probably $<1 \%$ ) of slightly altered ignimbrite as lithic clasts

\section{Probably Miocene(?)}

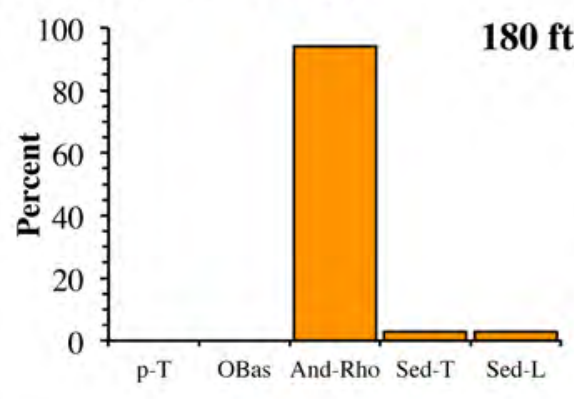

Sed-L is pumice-lithic-rich sediment

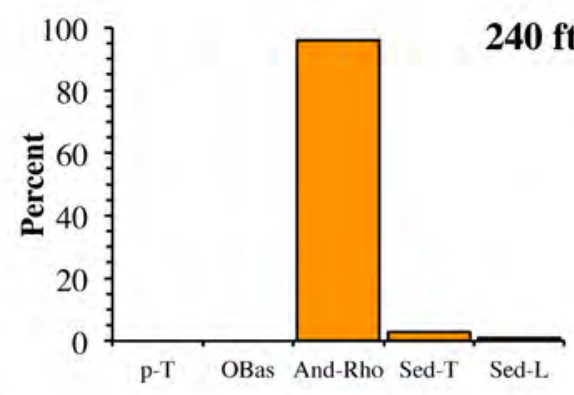

Sed-T is crystal-bearing tuff

Sed-L is pumice-lithic-rich sediment
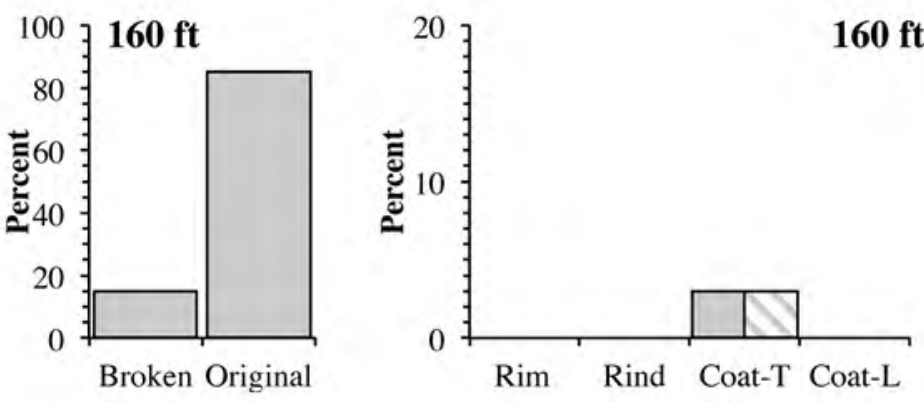

Cross hatched Coat- $T$ is the percent of the lithic-bearing tuffaceous matrix.

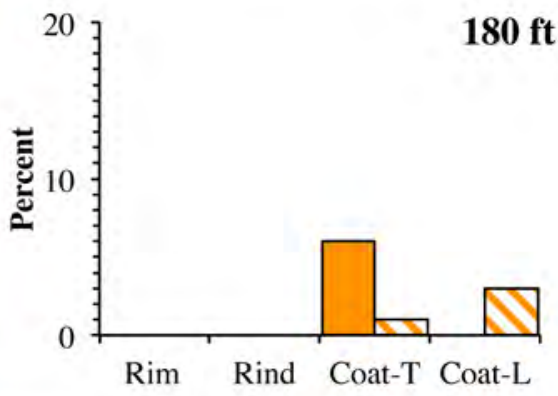

Cross hatched Coat- $\mathrm{T}$ is the percent of the lithic-bearing tuffaceous matrix.

Cross hatched Coat- $\mathrm{L}$ is the percent of the pumice-lithic-rich matrix.

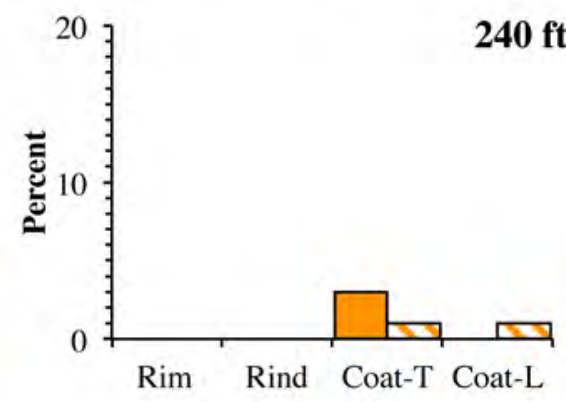

Cross hatched Coat- $T$ is the percent of the lithic-bearing tuffaceous matrix.

Cross hatched Coat- $\mathrm{L}$ is the percent of the pumice-lithic-rich matrix.

Figure 22.-Continued 


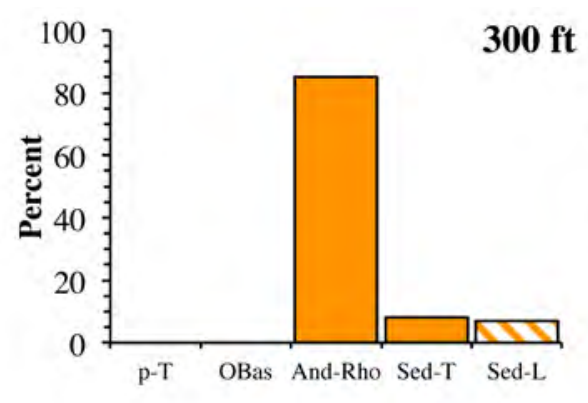

Sed- $\mathrm{L}$ is pumice-lithic-rich sediment

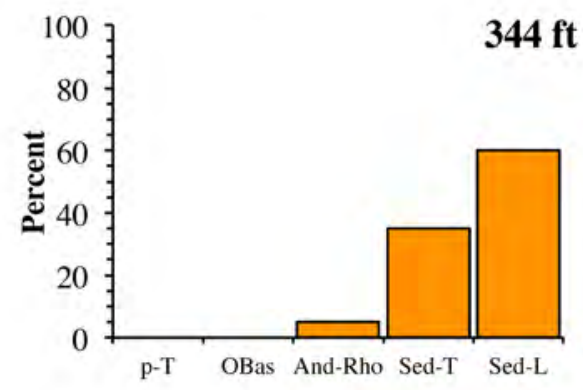

Sed-T is very fine-grained tuff or tuffaceous siltstone to sandstone

Sed-L is pumice-bearing, lithic-rich, fine-grained sandstone in very fine-grained tuffaceous(?) matrix
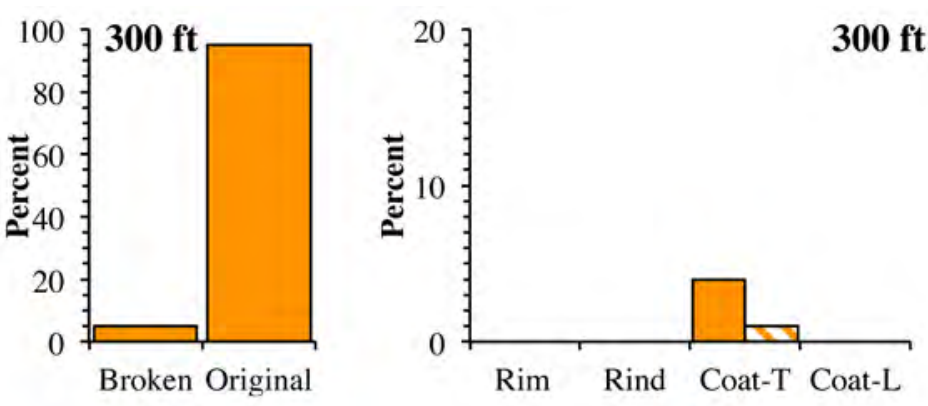

Cross hatched Coat-T is the percent of the lithic-bearing tuffaceous matrix.
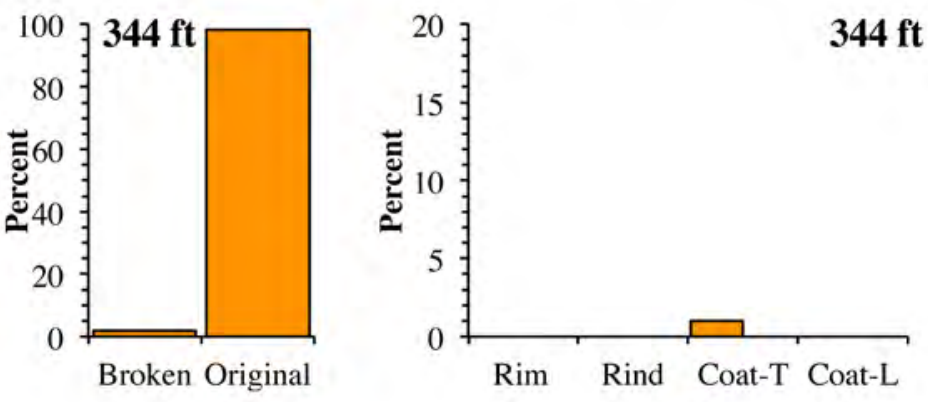

Figure 22.-Continued

\section{Miocene Tuffaceous Sediments (170-840 ft) in NELT2}

Based on a general overview of the cuttings samples, there are three apparent general lithologic sequences from 180 to $840 \mathrm{ft}$ (fig. 20). From 180 to $330 \mathrm{ft}$, there appear to be several tuffaceous sequences interstratified with mostly lithic-rich sediments that also appear to have slightly lighter colors and possibly smaller fragments with an increase in depth. From 340 to 590 $\mathrm{ft}$, the cuttings appear to be primarily pumiceous tuff or tuffaceous sandstone. From 600 to 840 $\mathrm{ft}$, there are two apparently tuffaceous samples (at 610 and $630 \mathrm{ft}$ ) that are interstratified with gradationally more lithic-rich sedimentary rocks (and another tuffaceous sample at $760 \mathrm{ft}$ ).

Based on detailed examination of cuttings, at $180 \mathrm{ft}$ there is (1) the first down-hole occurrence of fragments of tuffaceous and pumice-lithic-rich sediments, and (2) a slight increase in the amount of very fine-grained tuffaceous coatings (a few are crystal-bearing) and pumicelithic-rich coatings (fig. 22). From 180 to $300 \mathrm{ft}$, most lithic fragments consist of various types of (typically crystallized) lava flows with small amounts of fragments of tuffaceous and pumicerich, lithic-rich sediments. The amounts of tuffaceous and pumice-lithic-rich sediments gradationally increase with depth until there is a large increase at $344 \mathrm{ft}$ (tuffaceous materials are 35 percent, lithic-rich sediments are 60 percent).

The broken or original surfaces on lithic fragments are similar for samples from 180 to $300 \mathrm{ft}$, but there is a change to much smaller fragments at $344 \mathrm{ft}$. In the samples from 180, 240, and $300 \mathrm{ft}$, broken fragments comprise $3-10$ percent of all fragments, and the largest fragments 
with mostly broken surfaces are $5 \times 6 \times 10,4 \times 6 \times 10$, and $1 \times 6 \times 11 \mathrm{~mm}$ (respectively). Portions of these fragments with an original surface have curvatures that imply the size of the original clast was large, but could not be determined. In the samples from 180, 240, and $300 \mathrm{ft}$, the largest fragments with all original surfaces are $4 \times 6 \times 9,3 \times 4 \times 10$, and $5 \times 5 \times 8 \mathrm{~mm}$, respectively. Most grains that are less than 5-6 mm have surfaces that are mostly original, and these were likely plucked from the host sedimentary rock. The similarity in sizes of the maximum broken and original fragments probably results from the conditions during drilling (that is, what size fragment can be lifted out of the borehole by the circulating fluid), but the important relations of these values are (1) the maximum lithic fragment sizes in these samples are smaller than those in samples from 60 to $160 \mathrm{ft}$, (2) the 3-10 percent of the broken fragments imply there are few large clasts, (3) most fragments are original lithic clasts that are less than $10 \mathrm{~mm}$ in maximum diameter, and (4) most clasts are less than $5 \mathrm{~mm}$ in diameter. In the sample from $344 \mathrm{ft}, 98$ percent of the lithic fragments have original sizes and shapes (the largest clast with all original surfaces is $2 \times 3 \times 3 \mathrm{~mm}$ ), and of the broken fragments, only one fragment has all broken surfaces. Several samples from 330 to $370 \mathrm{ft}$ had a cursory examination, and although there were some variations in the details, all were similar to the relatively fine-grained, tuffaceous sediments described in sample from $344 \mathrm{ft}$. In the rig lithology log, "ash(?)” was noted at $335 \mathrm{ft}$, although this bed was not specifically collected in the cuttings samples (Anthony Brown, USGS, written commun., 2011).

The three core samples from 200, 400, and $720 \mathrm{ft}$ help constrain the characteristics of the host sedimentary rocks at these depths. The core sample from $200 \mathrm{ft}$ (fig. 23) consists of a lithicrich sandstone where lithic clasts are mostly crystallized lava flows, a few possible ignimbrites, and a few possible tuffaceous clasts. The largest clasts are approximately $4 \mathrm{~mm}$ with most grains less than $1 \mathrm{~mm}$. Thin section analysis indicates that although most clasts are lithic grains, some are pumice clasts.

The core sample from $400 \mathrm{ft}$ (fig. 23) consists of a pumiceous tuff or tuffaceous sandstone. There are few, small-pebble lithic clasts. Pumice clasts are white to very pale brown, and as much as $5 \mathrm{~mm}$ in diameter (forming about 10 percent of the rock), grading to the ashsized grains (forming about 20 percent of the rock) in the matrix. Thin section analysis indicates many clasts are lithic or crystal grains; however, some are pumice clasts with fine-grained cuspate bubble-wall shards. Crystal fragments include feldspar, quartz, green and brown amphibole, minor amounts of biotite, possibly minor amounts of pyroxene, and sphene. There are also amorphous silica rods, plates, and "beaded rings" that are probably plant material (such as phytoliths). The core sample from $720 \mathrm{ft}$ consists of about 10 pieces of crystallized lava flow that are probably dacite or rhyolite (with 5-10 percent phenocrysts of feldspar, quartz(?), and hornblende), and these pieces vary in size from 15 to $130 \mathrm{~mm}$. There was no matrix recovered; however, these pieces probably represent clasts in a poorly sorted volcanic conglomerate.

\section{Correlations of Lithostratigraphic Features to Geophysical Data in NELT2}

Borehole NELT2 has borehole geophysical logs (fig. 21) that appear to correlate to several lithostratigraphic features. In the borehole gamma and resistivity log data, there are numerous log response correlations, and a few good examples of changes in the cycles above and below these depths are at $83,107,219,288,343,597$, and $700 \mathrm{ft}$. Some of the variations in gamma and resistivity from 0 to $80 \mathrm{ft}$ and 215 to $220 \mathrm{ft}$ are probably the result of irregularities in borehole walls (as indicated in the caliper values), and the changes at 215-220 ft might be influenced by the water table at $217 \mathrm{ft}$ (fig. 21). The slight changes in gamma and resistivity 

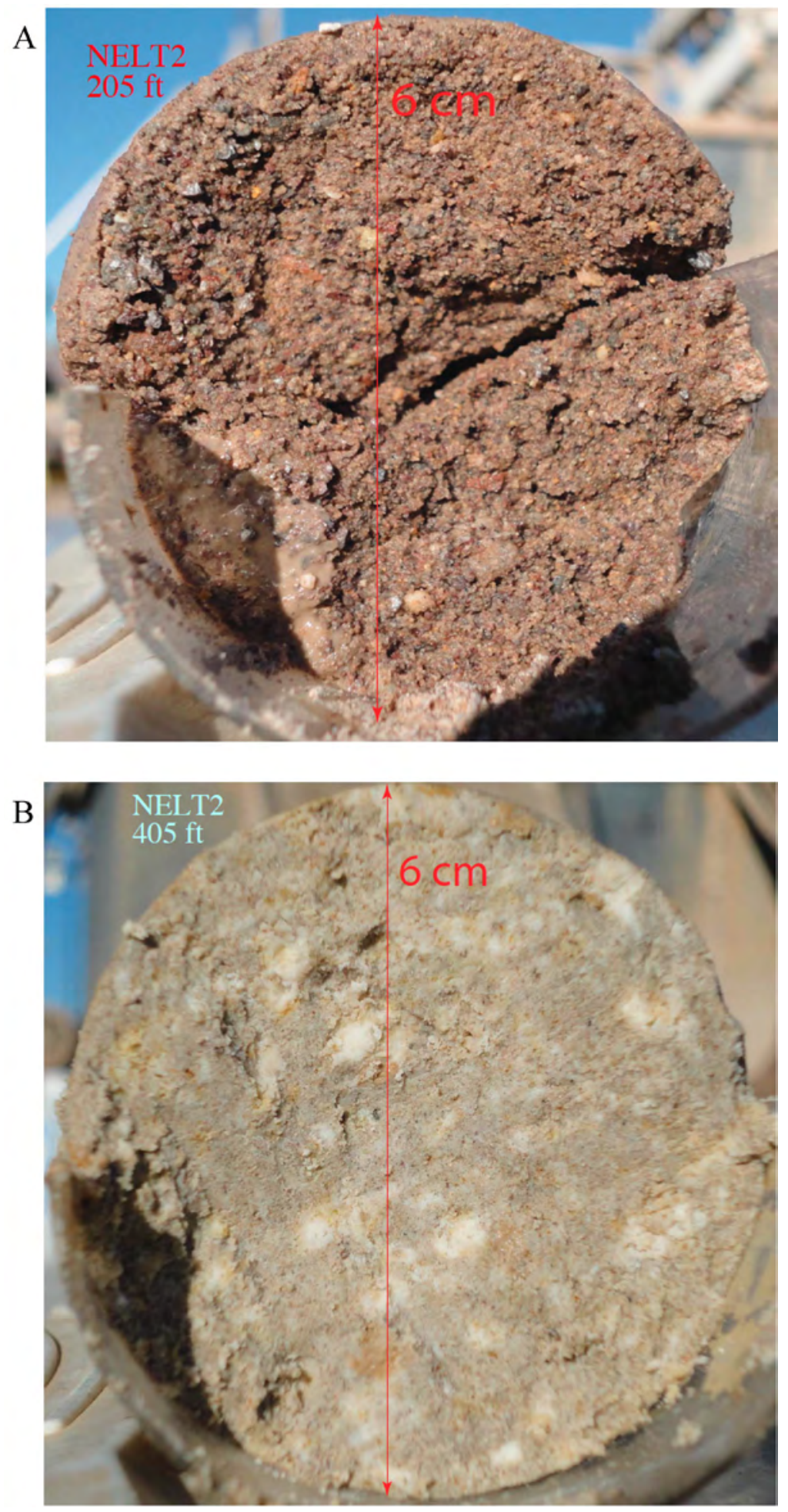

Figure 23. Photographs of core from borehole NELT2 at Fort Irwin, California. $A$, photograph of the bottom of core at $205 \mathrm{ft} ; B$, photograph of the bottom of core at $405 \mathrm{ft}$. U.S. Geological Survey photographs by Anthony Brown. 
characteristics at $55 \mathrm{ft}$ are consistent with slight changes in grain size or sorting, and the cuttings sample at $60 \mathrm{ft}$ is consistent with pebbly to cobbly sandstone or conglomerate. However, much of the large decrease in resistivity from 0 to $83 \mathrm{ft}$ probably results from barometrically driven drying of the shallow sedimentary materials. At depths below $83 \mathrm{ft}$, the relative humidity is probably fairly stable and gradually increases to the base of the unsaturated zone at $217 \mathrm{ft}$.

The implication of a fairly stable, relative humidity profile below $83 \mathrm{ft}$ is that lithologic variations such as grain size and sorting, and composition of the matrix such as the abundance and type of clay minerals, alter the resistivity. For example, the cuttings sample at $120 \mathrm{ft}$ is probably from a pebbly sandstone (the largest, mostly broken, lithic fragment is $8 \mathrm{~mm}$ ), and this sample is associated with relatively small resistivity values. These relations at $120 \mathrm{ft}$ are in contrast with the cuttings sample at $160 \mathrm{ft}$ that is probably from a coarser pebbly to cobbly sandstone (the largest, mostly broken, lithic fragment is $16 \mathrm{~mm}$ ), and at $160 \mathrm{ft}$ there are slightly larger resistivity values.

Based on the photographs of cuttings, there appears to be a sharp change in texture and color between the samples at 170 and $180 \mathrm{ft}$. There are small changes in the characteristics in gamma and resistivity values at $170 \mathrm{ft}$, so based on the uncertainties in depth resolution between the cuttings sample and the gamma and resistivity logs, it is likely that the sample at $170 \mathrm{ft}$ is at the base of a stratigraphic sequence. In the sample at $180 \mathrm{ft}$, although lithic fragments are as much as $10 \mathrm{~mm}$ in diameter and mostly original clasts, there is a slight increase in the amount of tuff and tuffaceous to pumiceous sandstone and associated matrix materials. This sample at 180 $\mathrm{ft}$ is associated with small resistivity values that appear to be consistent with the apparent interstratification of this bed with the otherwise coarser and more lithic-rich beds that have larger resistivity values.

The slightly lower resistivity values below $215 \mathrm{ft}$ (with the water table at $217 \mathrm{ft}$ ) probably result from the saturated conditions of the rocks. Many of the small variations in gamma and resistivity below $215 \mathrm{ft}$ are likely indicative of lithologic variations between beds and bedsets.

At $290 \mathrm{ft}$, there are changes in the character of the gamma and resistivity values. Compared to the gamma values above $290 \mathrm{ft}$, the gamma values below $290 \mathrm{ft}$ have shorter wavelength and smaller amplitude of the waveforms and cycles, and the mean values decrease down section. Although the character of RES(16N) and RES(64N) resistivity values is similar for the approximately 60 feet above and below this depth, the local mean value of resistivity values decreases by approximately 5 ohm-m.

In comparison to the sample at $240 \mathrm{ft}$, the sample at $300 \mathrm{ft}$ has greater amounts of crystallithic, pumiceous tuff, and siltstone to fine-grained sandstone with tuffaceous matrix. At $340 \mathrm{ft}$, there are changes in the values and characteristics of gamma and resistivity values, and these changes correlate to a sharp increase in the amount of tuffaceous material as matrix and possibly primary tuffaceous deposits. At $500 \mathrm{ft}$, there is a slight change in gamma and resistivity values and characteristics, and at $597 \mathrm{ft}$ there is a slightly larger increase in both types of data. Both increases are consistent with an increase in abundance, and (or) size, of lithic clasts.

Borehole NELT2 is approximately $256 \mathrm{~m}$ south of a TEM sounding (NL14) (fig. 2). The minimum-layer modeling of NL14 data results in a 5-layer model with a (1) moderate decrease in resistivity at $33 \mathrm{ft}$, (2) moderate increase at $85 \mathrm{ft}$, (3) moderate decrease at $164 \mathrm{ft}$, and (4) small increase at $308 \mathrm{ft}$ (values converted from the original model depths of 10, 26, 50, and $94 \mathrm{~m}$ (respectively); Burgess and Bedrosian, 2014). The depths to changes in resistivity values between the borehole and NL14 can differ because of (1) changes in thickness of lithostratigraphic units (and their properties), (2) the dip of lithostratigraphic units, and (3) 
possible separation across a fault (although no fault has been mapped between the borehole and NL14). In the TEM model values, the near surface decrease in resistivity is consistent with the barometrically driven drying out of the shallow sedimentary materials. The second TEM layer of small resistivity values from 33 to $85 \mathrm{ft}$ are thinner than, but are reasonably consistent with, the small resistivity values in the borehole from depths of 60 to $140 \mathrm{ft}$. The third TEM layer of moderately large resistivity values from 85 to $164 \mathrm{ft}$ is consistent with the approximately 80-ftthick sequence of moderate resistivity in the borehole from 150 to $215 \mathrm{ft}$. The fourth TEM layer of small resistivity values from 164 to $308 \mathrm{ft}$ is probably comparable to the small resistivity values in the borehole from 215 to about $340 \mathrm{ft}$. The fifth TEM layer of moderate resistivity values below $308 \mathrm{ft}$ is probably comparable to borehole resistivity below $340 \mathrm{ft}$ where there is a slight increase in values.

It is helpful to consider the fixed-thickness, 20-layer model results for the depths below $308 \mathrm{ft}$ in the TEM models (Burgess and Bedrosian, 2014). In the fixed-thickness model, there is a smaller increase in resistivity values at $318 \mathrm{ft}$ compared to the increase in the minimum-layer model at $308 \mathrm{ft}$. Also, from 318 to $722 \mathrm{ft}$ in the fixed-thickness model values, there is a gradational increase with several small step increases compared to the single value in the minimum-layer model. The numerous small increases in fixed-thickness model resistivity are consistent with the borehole resistivity values. When one considers the shift in TEM depths relative to borehole depths typically is between 40 and $60 \mathrm{ft}$, it is interesting to note that the small increase in TEM fixed-thickness values at $545 \mathrm{ft}$ is a reasonably good correlation to the borehole resistivity increase at about $590 \mathrm{ft}$. The inference from the increased gamma and resistivity values below $590 \mathrm{ft}$ is that this part of the lithostratigraphic section appears to have an increase in the amount, and (or) size, of volcanic lithic clasts, especially if they are dacite and rhyolite. The core at $720 \mathrm{ft}$ supports the increase in sizes of dacite or rhyolite lithic clasts.

\section{Summary of Lithostratigraphic Features and Units in Borehole NELT2}

There are four characteristics of lithostratigraphic features in borehole NELT2: (1) most samples from 60 to $160 \mathrm{ft}$ have almost entirely lithic volcanic fragments, and at $180 \mathrm{ft}$ the samples begin a progressive increase in the amounts of tuffaceous sediment and tuffaceous lithic-rich sediment that are interpreted as the host-rock matrix, (2) throughout the upper half of the borehole, which has detailed component descriptions of cuttings, relatively large (85-98 percent) amounts of fragments have original (or mostly original) surfaces that imply the clasts were plucked from the drilled (host) sedimentary rock, (3) throughout the upper part of the borehole, most coatings are tuffaceous (lithic-poor or lithic-bearing) with a small amount of pumice-lithic-rich coatings and no lithic-rich coatings, and (4) the core at $720 \mathrm{ft}$ consists of clasts at least $130 \mathrm{~mm}$ in diameter of dacite and (or) rhyolite, and the matrix was soft enough to be washed away during drilling.

Samples from 60 to $160 \mathrm{ft}$ are consistent with coarse grained, possibly pebble to cobble, sandstone or conglomerate. The sample at $60 \mathrm{ft}$ might be from a different lithostratigraphic sequence as those from 120 and $160 \mathrm{ft}$. In contrast, samples from 180 to $344 \mathrm{ft}$ are consistent with downwardly fining grain sizes from pebbly lithic-rich sandstone with a tuffaceous matrix to tuffaceous sandstone and locally primary pumiceous tuff(?). The core sample from $400 \mathrm{ft}$ consists of a pumiceous tuff or tuffaceous sandstone with a few, small-pebble lithic clasts, pumice clasts that are as much as $5 \mathrm{~mm}$ in diameter and grade down to ash-sized grains in the matrix. The matrix consists of small lithic, pumice, and crystal grains with fine-grained cuspate bubble-wall shards, and amorphous silica grains that might be phytoliths. 
There are no geochronologic controls on the deposits in NELT2. There are two likely alternatives to the position of the Quaternary(?)/Pliocene(?) rocks and the Miocene(?) rocks. These alternatives depend on the trends in lithologic features. One possibility is that the lithostratigraphic section is divided into the sedimentary rocks from 0 to $170 \mathrm{ft}$ that were deposited during the inferred Quaternary(?)/Pliocene(?), and more tuffaceous sedimentary rocks from 170 to $840 \mathrm{ft}$ that were deposited during the Miocene(?) (table 3). Alternatively, it is possible that the top of the Miocene(?) rocks are as shallow as 83 or $107 \mathrm{ft}$ (table 3), based on the coatings and slight change in gamma and resistivity characteristics. The balance between these two alternatives is based on what criteria are used. If one uses the occurrence of pieces of tuffaceous rocks in the lithology component data (the left graph in fig. 22), then tuffaceous rock fragments first occur at about 160 or $180 \mathrm{ft}$, depending on how the slightly altered ignimbrite clast is treated. The challenging part of those data is that in this, and other boreholes at Fort Irwin, the tuffaceous and lithic-rich sedimentary rocks appear to be disaggregated during drilling; therefore, only where sedimentary rocks that are lithified will they occur as fragments in the cuttings. If one uses the tuffaceous coating data where there are mostly tuffaceous coatings, then the contact would be somewhere between 60 and $120 \mathrm{ft}$ (the right graph in fig. 22). If the gamma and resistivity values are used, there are coherent cycle boundaries at $83 \mathrm{ft}$ and $107 \mathrm{ft}$, and the different cycle characteristics above and below these depths are supported by the more lithic and more tuffaceous sedimentary rocks at 60 and $120 \mathrm{ft}$, respectively. Good arguments can be made for either of the cycle boundaries at $83 \mathrm{ft}$ and $107 \mathrm{ft}$ being the main contact associated with the Quaternary(?)/Pliocene(?) rocks and the Miocene(?) rocks. Similar alternative interpretations of contacts occur in boreholes NELT1, NELT5, and NELT6, and in boreholes NELT3 and NELT4 only one contact each was identified; however, all boreholes have a contact within the range from 104 to $130 \mathrm{ft}$ (table 3). Therefore, for general stratigraphic consistency, the contact associated with the Quaternary(?)/Pliocene(?) rocks and the Miocene(?) rocks in NELT2 is identified at $104 \mathrm{ft}$ with $83 \mathrm{ft}$ as an alternative (table 3).

\section{Interpretations for Stratigraphy in NELT4}

Borehole NELT4 is about midway across the Nelson basin in the topographic low east of the large dacitic dome, north of a ridge formed by felsic and mafic plutonic rocks, and in the drainage that ends in Bicycle Lake (Miller and others, 2014; fig. 2). Cuttings samples were collected from the shaker table in 10-ft intervals (fig. 24), and three core samples were collected at 200, 500, and $880 \mathrm{ft}$ with core recovery of 92, 64, and 55 percent, respectively (Adam Kojs, USGS, written commun., 2012; fig. 25). Detailed component data for NELT4 to a depth of $240 \mathrm{ft}$ are summarized in figure 26. Approximately $515 \mathrm{~m}$ to the southeast of the borehole is a TEM sounding (NL13) (Burgess and Bedrosian, 2014; fig. 2).

\section{Lithostratigraphic Features in NELT4}

From 60 to $110 \mathrm{ft}$, although there are crystallized volcanic lithic fragments, most other fragments are lithic-rich sediment. From 60 to $110 \mathrm{ft}$, there are very few tuffaceous fragments, and many of these are probably lithic clasts derived from Miocene volcanic rocks. However, from $120 \mathrm{ft}$ and below, most of the fragments are tuffaceous. At $60 \mathrm{ft}$, about 10 percent of the fragments are lithic-rich sediments that are cemented by calcite, and about 75 percent of the fragments are very fine-grained (soft) and locally cemented that probably represents playa or groundwater discharge deposits. At $70 \mathrm{ft}$, lithic fragments (as large as $4 \times 5 \times 7 \mathrm{~mm}$ ) have their original shape, most lithic clasts are less than $2 \mathrm{~mm}$, and the coatings are white, very fine-grained 
siltstone (possibly tuffaceous?). From 80 to $100 \mathrm{ft}$, the lithic-rich sedimentary materials are lithicbearing to lithic-rich, white, very fine-grained siltstone where the matrix is partially replaced by calcite(?). Most lithic fragments (the largest in various samples range from $2 \times 4 \times 5 \mathrm{~mm}$ to $4 \times 6 \times 8$ $\mathrm{mm}$ with $6 \times 8 \times 12 \mathrm{~mm}$ at $100 \mathrm{ft}$ ) have original surfaces; and therefore, were plucked from host rocks. These siltstones might represent groundwater discharge deposits.

From 120 to $260 \mathrm{ft}$, the drilled host-rock deposits vary from tuffaceous and pumiceous deposits (including pumiceous crystal-bearing ignimbrite fragments from 120 to $140 \mathrm{ft}$ ) to crystallithic siltstone to sandstone. The core at $200 \mathrm{ft}$ is slightly mottled pale red and light olive gray, fine-grained sandstone to siltstone with about 25 percent very small white grains (presumably pumice grains). From 240 to $260 \mathrm{ft}$ there are 98-99 percent white, lithic-bearing to lithic-rich, very fine-grained micritic sandstone or siltstone beds, and 1-2 percent small, crystallized volcanic clasts. Test fragments from 250 and $260 \mathrm{ft}$ are almost completely (99-98 percent, respectively) dissolved in dilute $\mathrm{HCl}$, indicating that these samples consist of almost 100 percent carbonate mudstone (micrite). The rig lithology log indicates a possible tephra deposit from 257 to $260 \mathrm{ft}$, and this identification might have been influenced by the very fine-grained white fragments.

With the exception of a "quick look" at cuttings from $360 \mathrm{ft}$, samples below $260 \mathrm{ft}$ were not examined for detailed components, however, the rig chatter, borehole geophysical logs, and photographs of shaker cuttings and core (Adam Kojs, USGS, written commun., 2012; fig. 25) provide insights into the host-rock characteristic. From 0 to $260 \mathrm{ft}$, rig chatter was rare with "hard” noted at $127 \mathrm{ft}$, "hiccupping” at about $147 \mathrm{ft}$, and "harder" at $183 \mathrm{ft}$. Chatter started again at a depth of $358 \mathrm{ft}$, the amount of chatter increased from 358 to $400 \mathrm{ft}$, and from 400 to $768 \mathrm{ft}$, rig chatter occurred for 1-4-ft thick sequences interlayered with 1-10-ft thick sequences of no chatter (fig. 25). The core at $500 \mathrm{ft}$ had 64 percent recovery and consists of pebbly sandstone with slightly rounded clasts up to $20 \mathrm{~cm}$ in diameter in a medium-grained sandy matrix. From 768 to about $860 \mathrm{ft}$, the rig chatter log uses alternating terms such as chatter, hard, and soft between segments with no description. The photograph of shaker cuttings has changes in texture and color of cuttings to what appears to be more lithic-rich material at $360 \mathrm{ft}$ (fig. 24). The core from 880 to $885 \mathrm{ft}$ had a recovery of 55 percent and consists of $2.8 \mathrm{ft}$ of foliated gneiss pieces with hematite and limonite coated fractures spaced approximately 3-6 cm apart, and this core is from in-place bedrock.

\section{Correlations of Lithostratigraphic Features to Geophysical Data in NELT4}

From 0 to $260 \mathrm{ft}$, there are several variations in some of the gamma, resistivity, and spontaneous potential geophysical logs, with some of the largest variations and the best coherence of different types of data at about $118 \mathrm{ft}$. Some of these changes in values, characteristics, and cycles in gamma, resistivity, and spontaneous potential are highlighted on figure 25. From 40 to 61 $\mathrm{ft}$, there are large amplitude and short wavelength cycles of resistivity, three $2-8$ - $\mathrm{ft}$ thick cycles in gamma, and two 8-10-ft thick cycles in spontaneous potential. The sample at $60 \mathrm{ft}$ consists of lithic-rich siltstone to fine-grained sandstone that is partially cemented by calcite and probably represents playa or groundwater discharge deposits. From 61 to $82 \mathrm{ft}$, there are moderate amplitude and wavelength cycles in resistivity with two cycles in gamma with different characteristics that are about $10 \mathrm{ft}$ thick, and one general cycle of spontaneous potential with up-hole increasing wavelength and amplitude, but decreasing mean values. The sample at $70 \mathrm{ft}$ is from a sandy siltstone. From 82 to $118 \mathrm{ft}$, there are large amplitude and wavelength cycles of resistivity, and five $2-8-\mathrm{ft}$ thick cycles in gamma and four 6-10-ft thick cycles of spontaneous potential. Samples from 80 to $100 \mathrm{ft}$ are lithic-rich, very fine-grained siltstone that is partially cemented by calcite. 
A

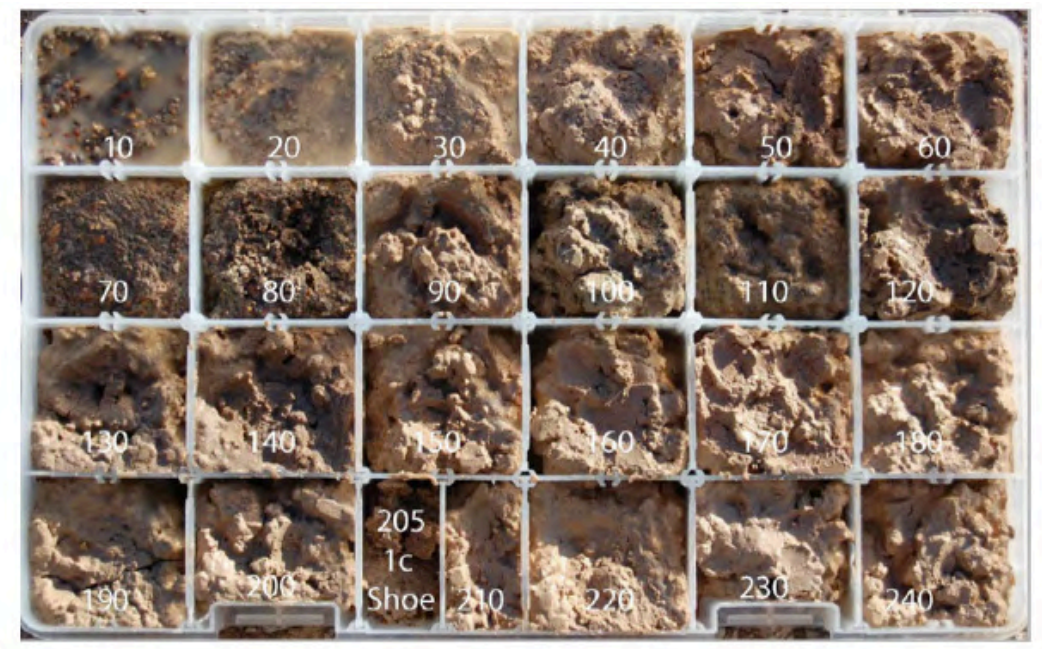

B

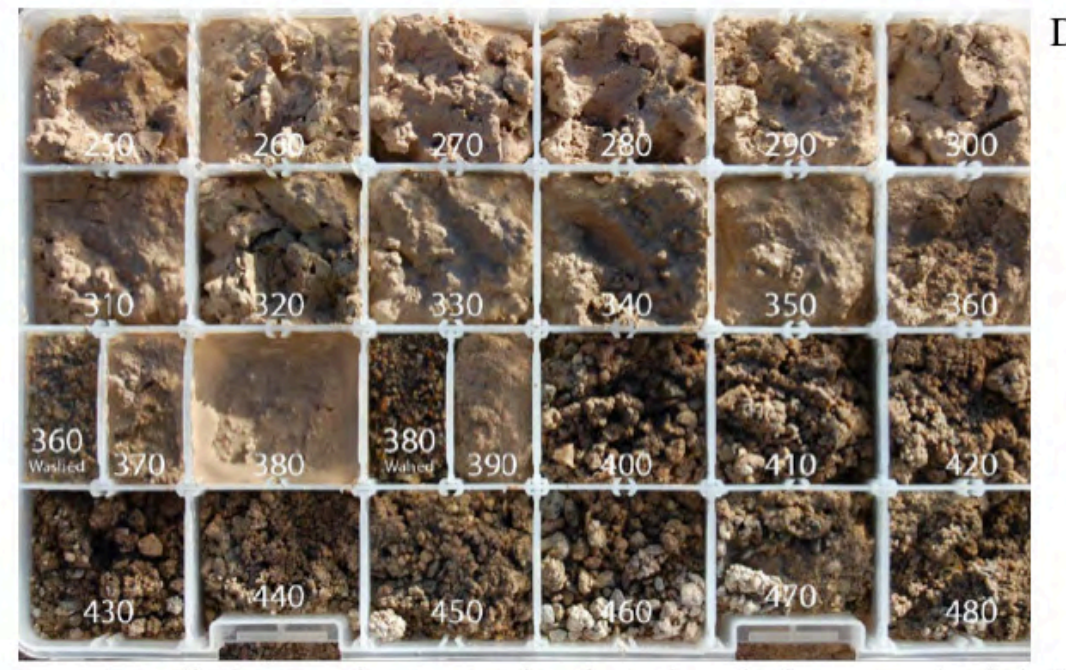

$\mathrm{C}$

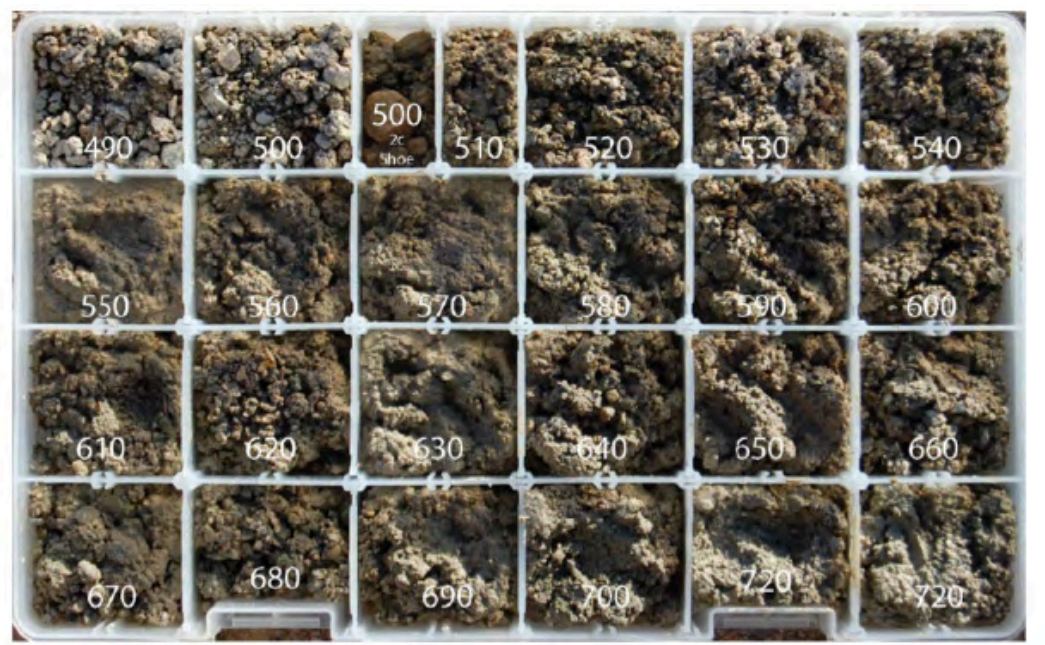

D

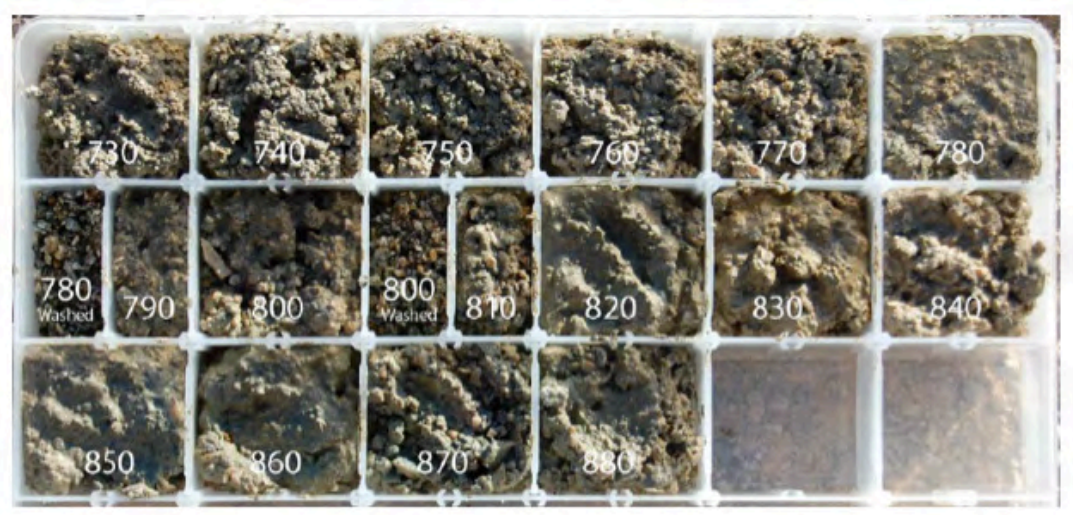

Figure 24. Photographs of cuttings from the shaker table for borehole NELT4 at Fort Irwin, California. $A$, samples from 10 to $240 \mathrm{ft} ; B$, samples from 250 to $480 \mathrm{ft}$; $C$, samples from 490 to $720 \mathrm{ft} ; D$, samples from $730 \mathrm{to} 880 \mathrm{ft}$. Core samples at 205, $503,885 \mathrm{ft}$. Samples at 360, 380, 780, and $800 \mathrm{ft}$ have washed split samples. A square chip cell is $50 \times 55 \mathrm{~mm}$. U.S. Geological Survey photographs by Adam Kojs. 


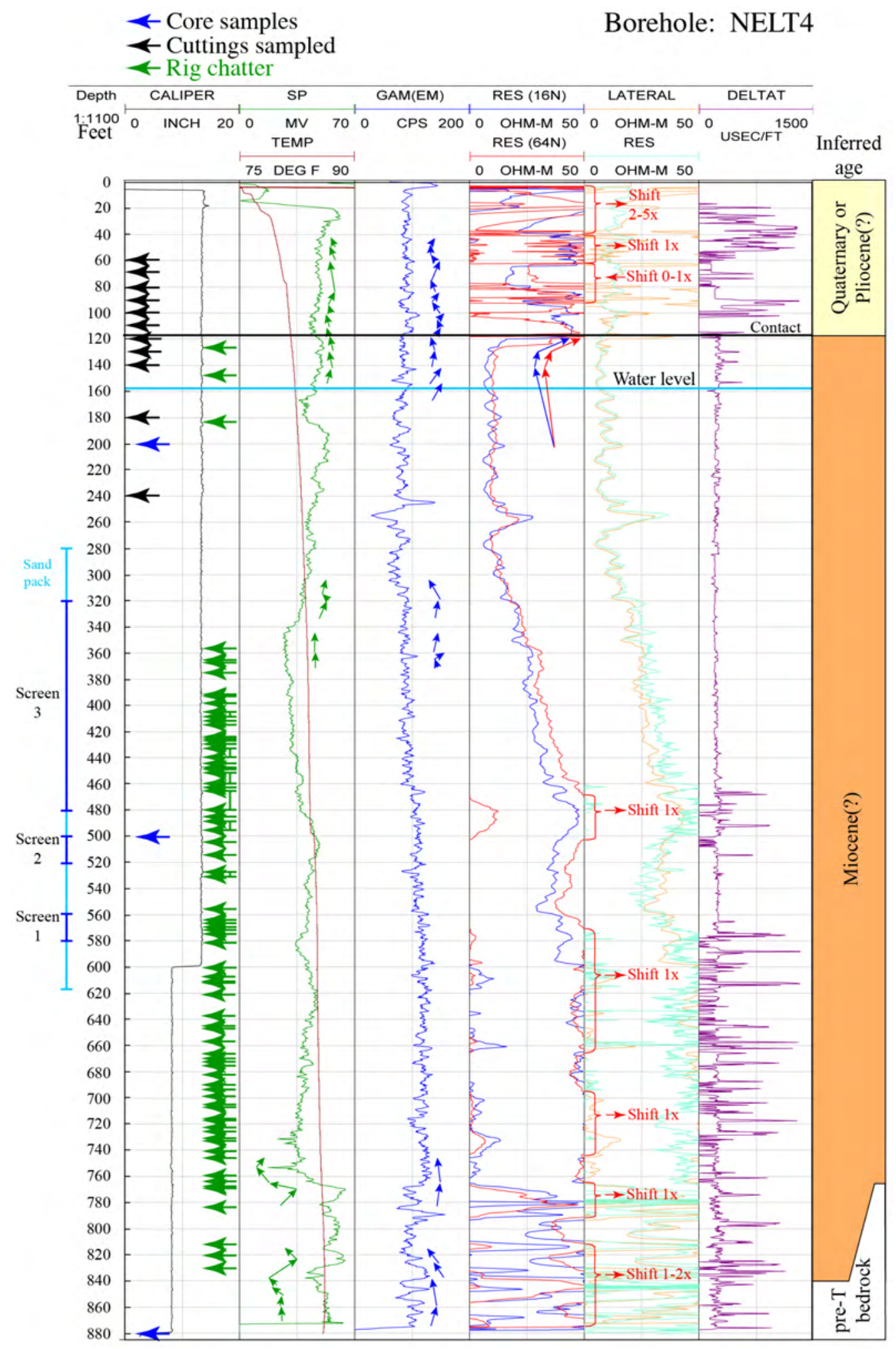

Figure 25. Graph showing locations of cuttings samples in borehole NELT4 at Fort Irwin, California, used for detailed examination compared to core, borehole geophysical logs, rig chatter, and locations of screened intervals 1,2 , and 3 in a single well. 
From 118 to $238 \mathrm{ft}$, there are various 3-20-ft thick cycles in resistivity gamma and spontaneous potential that correlate to an increase in the amount of tuffaceous and pumiceous deposits (fig. 25). From 118 to $121 \mathrm{ft}$, there is a sharp decrease in resistivity values, a decrease in gamma, and an increase in spontaneous potential. From 121 to $141 \mathrm{ft}$, there are two cycles of a decrease in resistivity, a decrease in the mean values of gamma, and a slight increase in the mean values of spontaneous potential values. Cuttings samples from 120 to $140 \mathrm{ft}$ are from what appears to be pumiceous crystal-bearing ignimbrite that might be interstratified with crystallithic siltstone to sandstone. The partially calcite-cemented, lithic-rich, very fine-grained siltstone (as in the sample at $110 \mathrm{ft}$ ) and the pumiceous ignimbrite at $120 \mathrm{ft}$ appear to have very different geophysical properties. The sharp, but gradational, decrease or increase in geophysical log values from 118 to $121 \mathrm{ft}$ results from the spacing of sensors on resistivity and spontaneous potential logging tools and the 2-ft moving average of the gamma values as they move past the lithostratigraphic contact of the siltstone and ignimbrite, which is probably at $118 \mathrm{ft}$. From 141 to $238 \mathrm{ft}$, there are several cycles in resistivity, gamma, and spontaneous potential. The sample at $180 \mathrm{ft}$ is from tuffaceous and pumiceous deposits and contains many pumice clasts, some with attached tuffaceous matrix. The delicate pumiceous textures are consistent with a lack of significant mechanical abrasion (as would be expected in a stream transported clast); therefore, these deposits appear to be either primary pyroclastic flow or fallout tephra deposits, or very minimally reworked pyroclastic deposits. Water level is at $159 \mathrm{ft}$ (Kojs and others, 2014; fig. 25). There are no changes in the resistivity, gamma, and spontaneous potential values that appear to be influenced by transition from the unsaturated to saturated zone, and it is likely the correlations to lithostratigraphic properties are the main controlling features.

In the TEM data from NL13, there is a sharp decrease in minimum-layer model resistivity with depth at $26 \mathrm{ft}$ and another decrease at $115 \mathrm{ft}$ (Burgess and Bedrosian, 2014). The decrease in modeled resistivity at $115 \mathrm{ft}$ correlates well to the sharp increase in tuffaceous and pumiceous sedimentary rocks below $118 \mathrm{ft}$.

From 240 to $260 \mathrm{ft}$, there is a peak-trough doublet in gamma and peak resistivity values, and these appear to correlate well with the micritic beds. From 242 to $255 \mathrm{ft}$, there is a moderately large peak and trough pair of gamma values. Gamma values are typically influenced by the amounts of K, U, and Th (Keys and MacCary, 1971; Keys, 1990), and these elements are larger in rhyolitic rocks compared to more mafic rocks, such as andesitic and basaltic rocks; therefore, it is possible that this peak is from a tuff bed. Although the samples at 240, 250, and $260 \mathrm{ft}$ are white and very fine-grained, with a dissecting microscope examination of washed samples, they provide no direct evidence for such (rhyolitic) tephra beds. In fact, selected test fragments from 250 and $260 \mathrm{ft}$ almost entirely dissolve in dilute $\mathrm{HCl}$, indicating they are probably very fine-grained micrite. The pattern observed on the gamma log therefore remains unexplained.

Below $260 \mathrm{ft}$, there are numerous changes in values and characteristics in gamma and resistivity data (and locally spontaneous potential data), and a few notable changes are at 280, 319, 360, 460, 763, and $838 \mathrm{ft}$. Near the bottom of the borehole, the largest change of values and characteristics in all three geophysical logs occurs at $763 \mathrm{ft}$. In the rig lithology log, weathered bedrock was identified at $777 \mathrm{ft}$, and the amount of weathering decreased to $840 \mathrm{ft}$ where the contact with foliated gneissic bedrock was identified. An alternative to the weathered bedrock contact at $777 \mathrm{ft}$ is that the changes in geophysical log values at $763 \mathrm{ft}$ probably represent lithicrich sedimentary rock form mostly from the foliated gneiss. The rig lithology log pick for the bedrock contact at $840 \mathrm{ft}$ is consistent with the changes in the geophysical log values at $838 \mathrm{ft}$. 
Probably Quaternary to Pliocene(?)

Fine-grained, locally tuffaceous, sandstone and groundwater discharge deposits
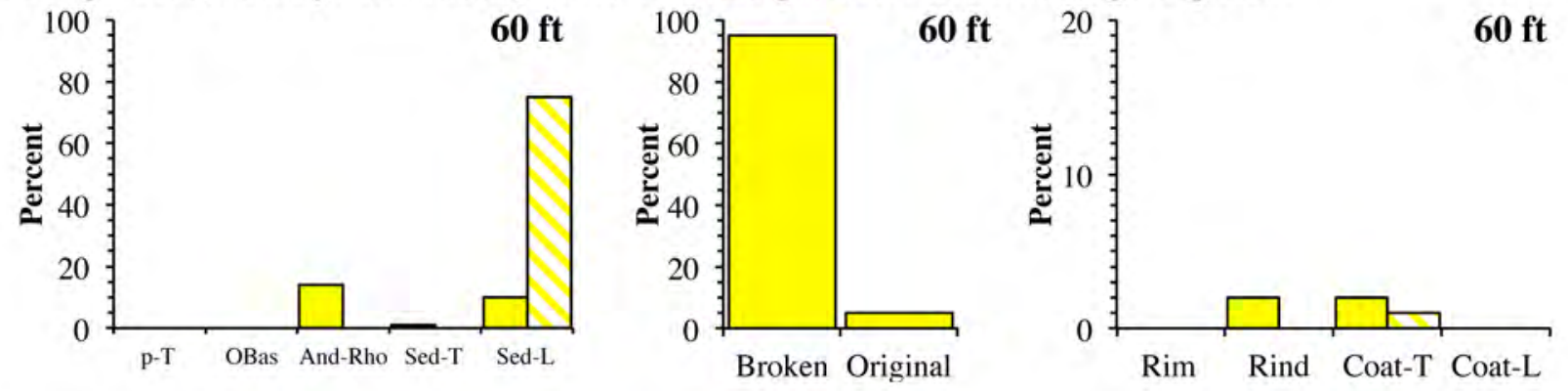

Cross hatched Sed-T is fine-grained, lithic-bearing sandstone and/or groundwater discharge deposits. Most And-Rhy grains are rounded-subrounded Broken fragments of cemented

Cross hatched Coat- $\mathrm{T}$ is the percent of the crystal-bearing tuffaceous matrix. (plucked from host rock).

lithic-rich sediment.
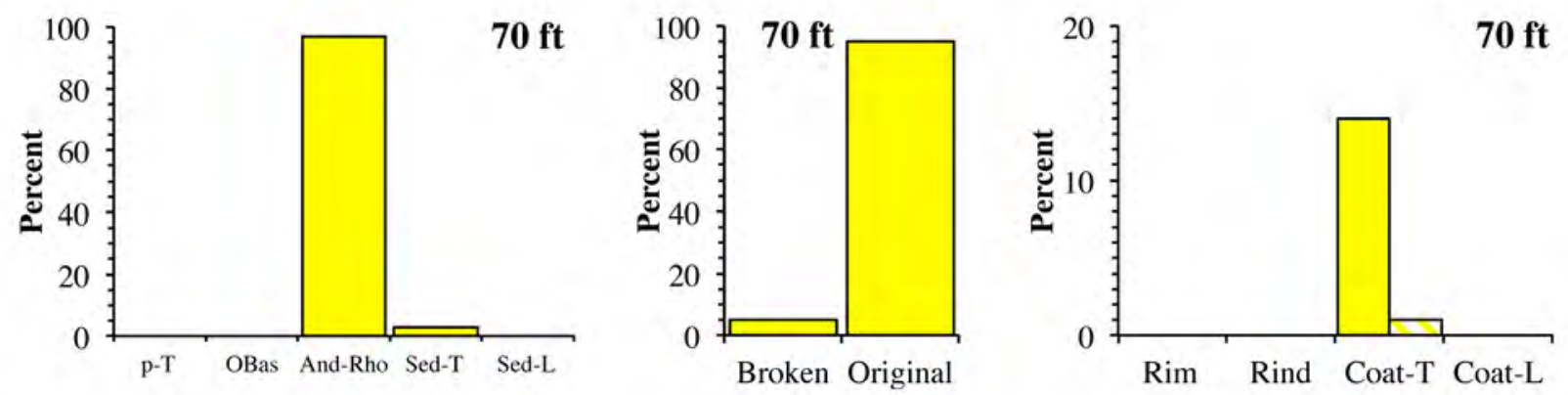

Sed-T are rounded lithic clasts of altered or crystallized tuffs (Miocene)

Cross hatched Coat- $\mathrm{T}$ is the percent of the lithic-bearing tuffaceous matrix.
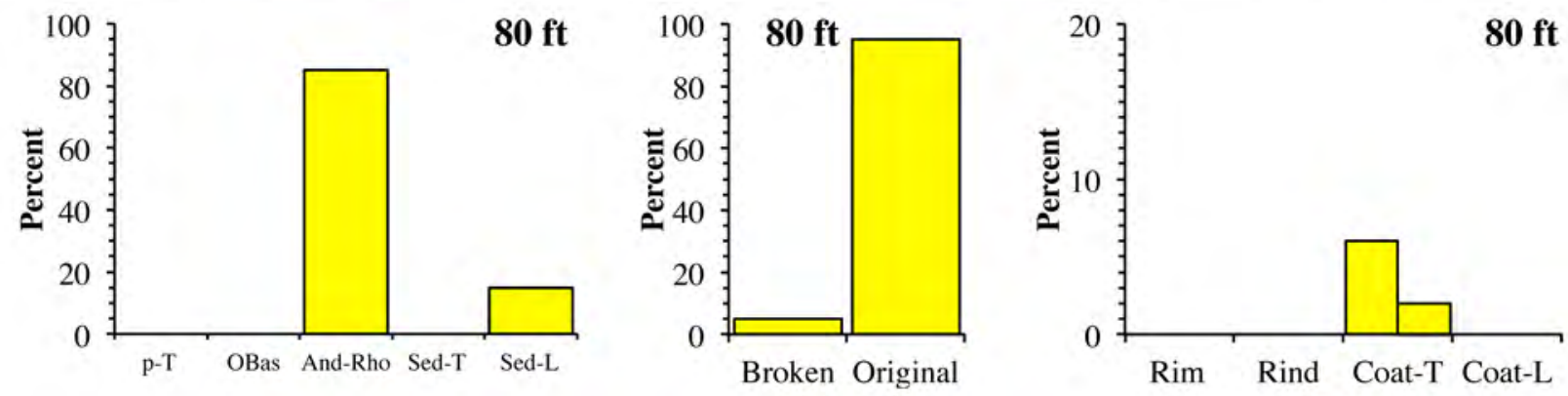

Sed-L is lithic-bearing-to-rich, very fine-grained siltstone (matrix partially replaced by calcite).

Cross hatched Coat- $\mathrm{T}$ is the percent of the lithic-bearing tuffaceous matrix.

Figure 26. Bar graphs of components of cuttings samples in borehole NELT4 at Fort Irwin, California. Lithostratigraphic units: yellow, lithic-rich sediment, probably Quaternary or Pliocene(?); orange, tuffaceous sediment, probably Miocene(?). Components: p-T, pre-Tertiary; Obas, porphyritic olivine basalt; And-Rho, andesite to rhyolite; Sed-T, tuffaceous sedimentary rocks, Sed-L, lithic-rich sedimentary rocks; Broken, broken surfaces; Original, original surfaces; Rim, thin layer of crystallization in volcanic rock along a cooling fracture; Rind, calcite, opal, or chalcedony deposits on a lithic clast; Coat-T, tuffaceous coatings; Coat-L, lithic-rich coatings. 


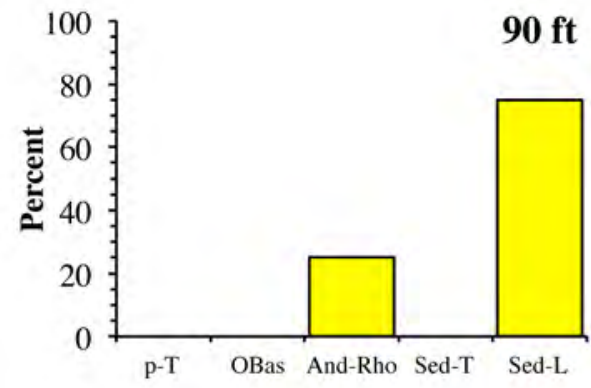

Sed-L is lithic-bearing-to-rich, very fine-grained siltstone (matrix partially replaced by calcite).

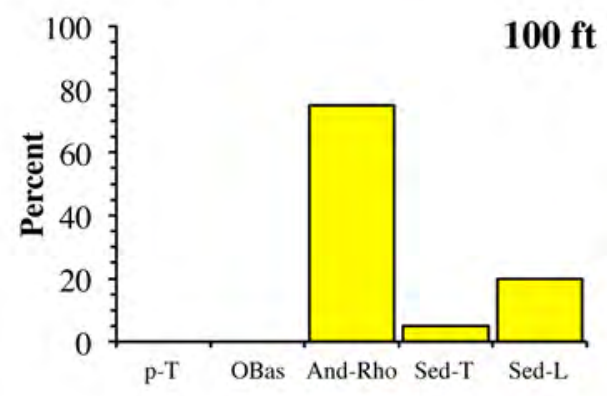

Sed-L is lithic-bearing-to-rich, very fine-grained siltstone (matrix partially replaced by calcite).

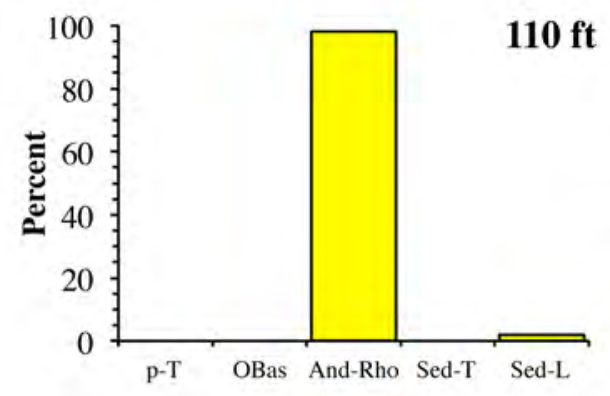

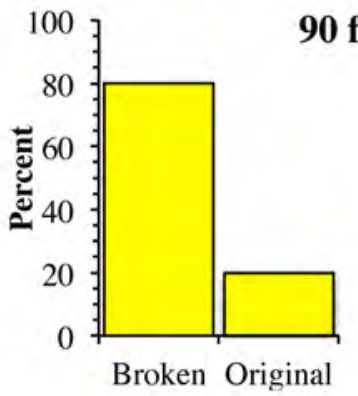

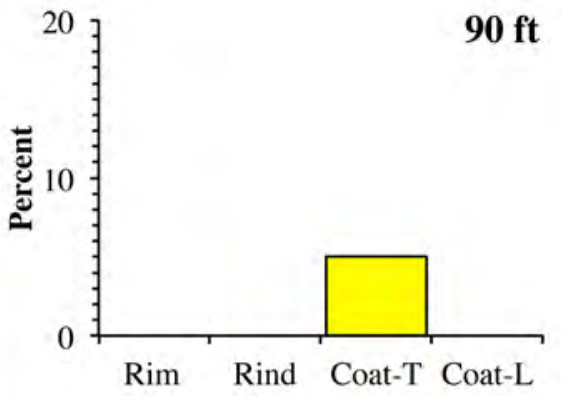

Few broken lithic clasts

Most broken fragments are

lithic-rich, fine-gr sandstone.
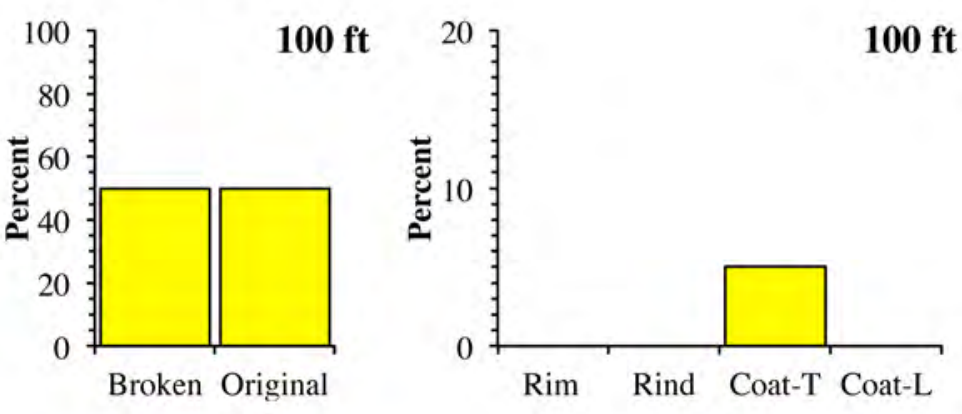

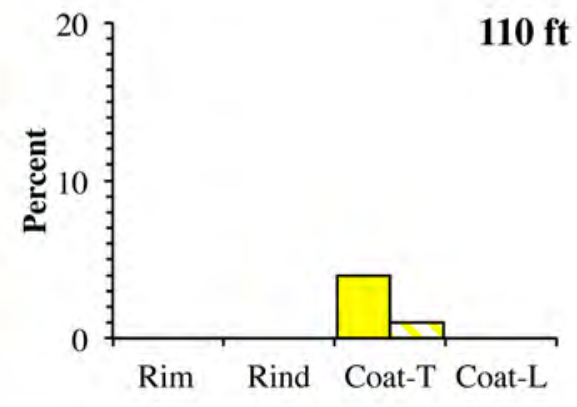

Cross hatched Coat- $\mathrm{T}$ is the percent of the lithic-bearing tuffaceous matrix.

Figure 26.-Continued 


\section{Probably Miocene(?)}
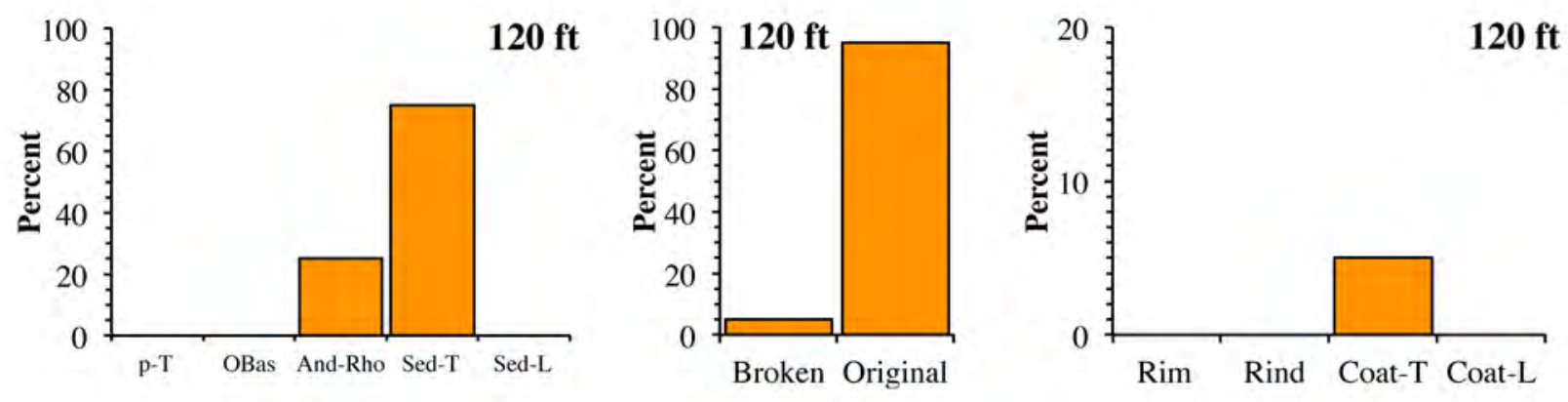

Sed-T has pumice fragments or pumiceous tuff
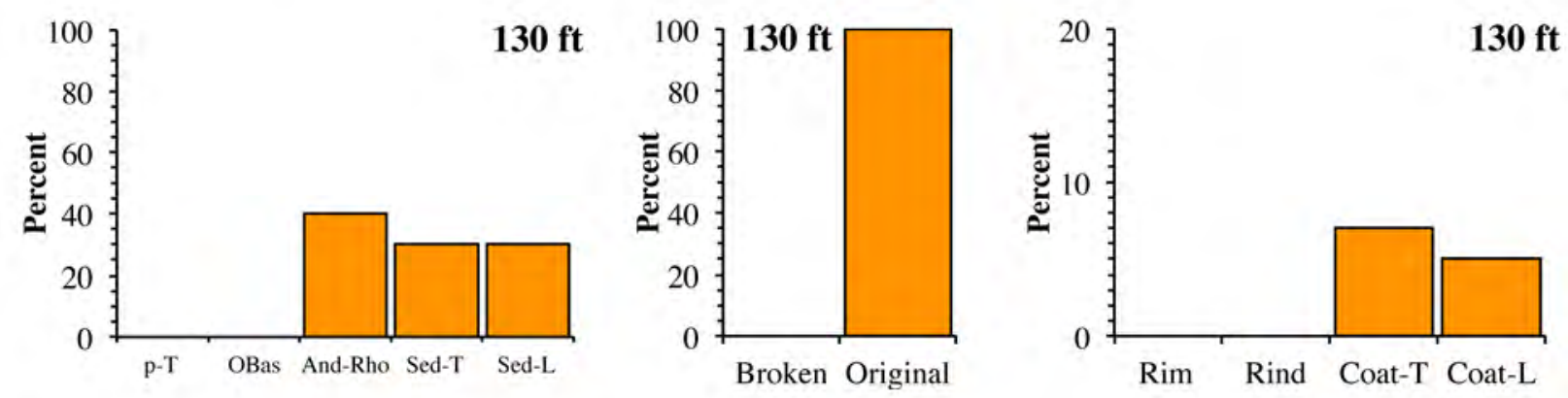

Sed-T has pumice fragments or pumiceous tuff Sed-L is siltstone to medium-grained, crystal-lithic sandstone
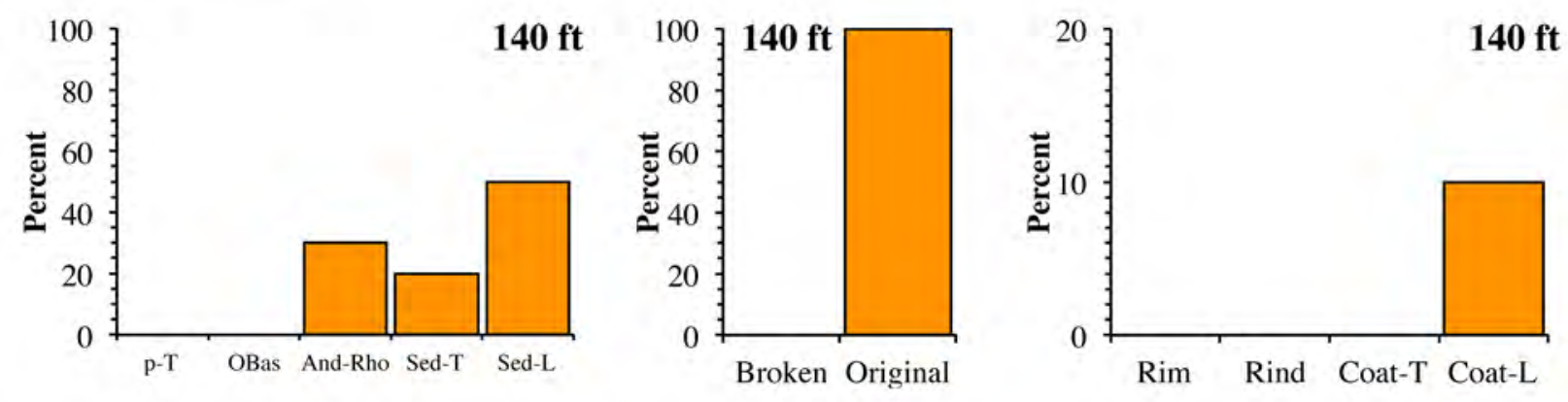

Sed-T has pumice fragments or pumiceous tuff

Sed-L is siltstone to medium-grained, crystal-lithic sandstone (some with root-twig casts)

Figure 26.-Continued 

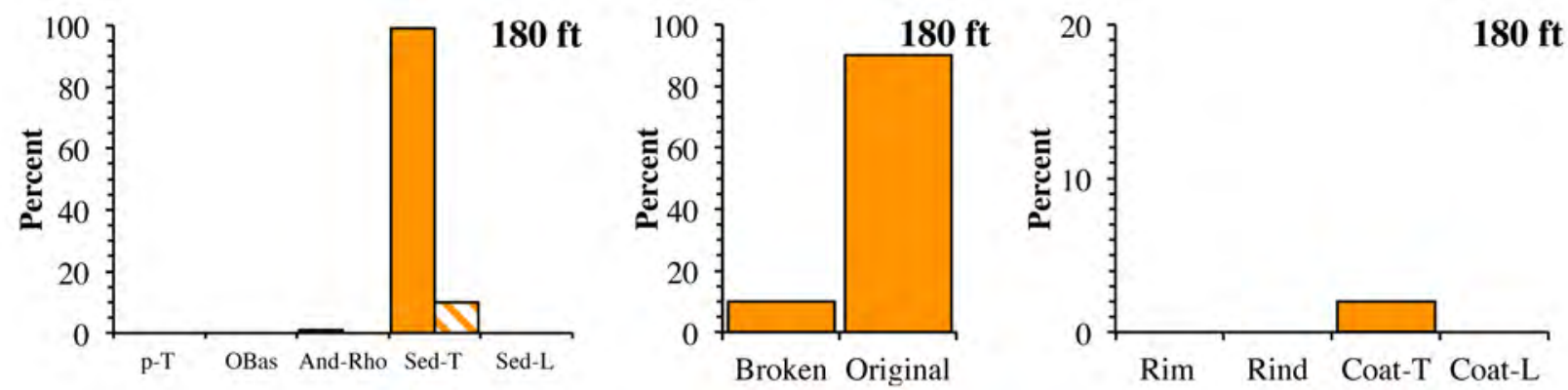

Sed-T includes long-tube pumice and fine-grained

tuffaceous matrix with some crystal, lithic, and pumice clasts.

Cross hatched Sed-T are lithic-bearing

with tuffaceous matrix.

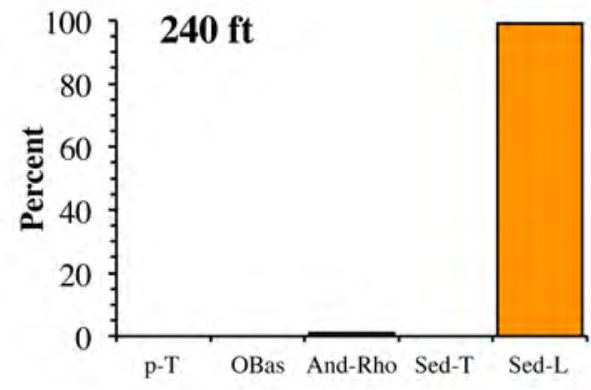

Sed-L is crystal-lithic bearing-to-rich micrite.

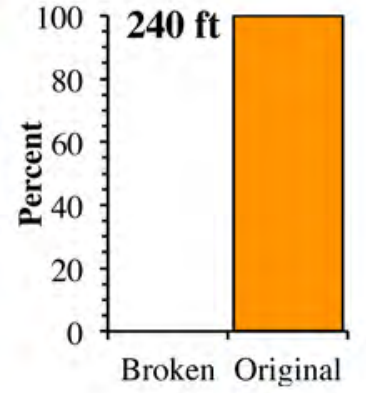

Broken Original

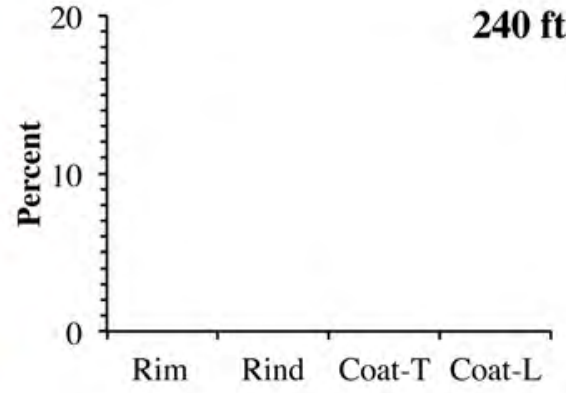

There are no rims, rinds, or coatings.

Figure 26.-Continued

\section{Summary of Lithostratigraphic Features and Units in Borehole NELT4}

The lithostratigraphic sequence from 0 to $118 \mathrm{ft}$ (samples from 60 to $110 \mathrm{ft}$ ) consists of lithic-rich sedimentary rocks interbedded with very fine-grained sandstone and siltstone that might represent groundwater discharge deposits, much of which is partially cemented by calcite. This sequence was probably deposited during the inferred Quaternary to Pliocene(?) (table 3). The lithostratigraphic sequence from 118 to $840 \mathrm{ft}$ (including samples from 120 to $240 \mathrm{ft}$ ) consists of (1) a possibly nonwelded ignimbrite from 120 to $140 \mathrm{ft}$, (2) a tuffaceous section of sandstone and possibly tephra beds from 140 to 319 or $360 \mathrm{ft}$, (3) an increasingly lithic-rich section of sandstone and conglomerate from $360 \mathrm{ft}$ to (about) $770 \mathrm{ft}$, and (4) a section with increased amounts of bedrock clasts from about 770 to about $840 \mathrm{ft}$. The section deeper than 118 $\mathrm{ft}$ was probably deposited during the Miocene(?), and most of the section is probably synvolcanic with the lowest part of the section (below $770 \mathrm{ft}$ ) possibly part of the prevolcanic sequence (fig. 25). The borehole penetrated pre-Tertiary gneissic bedrock at $840 \mathrm{ft}$.

\section{Interpretations for Stratigraphy in NELT5}

Borehole NELT5 is located in the western part of Nelson Lake basin (fig. 2). The borehole is located on older alluvial fan deposits (Quaternary geologic map unit Qoa of Miller and others, 2014) in an area with groundwater discharge deposits (Qg), young alluvial fan deposits (Qya), intermediate alluvial fan deposits (Qia), and extremely old alluvial fan deposits (early Pleistocene to early Pliocene, QToa) about $2.4 \mathrm{~km}$ to the west northwest, where they are 
about 35-60 m thick. Miocene felsic volcanic rocks (fv) are exposed $1.4 \mathrm{~km}$ to the southwest (Miller and others, 2014). Exposures of the Qoa to the north of the borehole are about $30 \mathrm{~m}$ thick, and about $15 \mathrm{~m}$ are exposed on the hill adjacent to the borehole (where neither the top nor bottom of Qoa is exposed in either area), but it is likely that the top of the borehole is in the lower part of the Qoa section. In this area, some of the thickness relations of the Quaternary deposits are complicated by the younger rocks being deposited in areas that had been eroded into the older rocks. Given these local variations in thickness of these Quaternary deposits, the shallowest rocks in the borehole were likely deposited during the early Quaternary.

In borehole NELT5, cuttings samples were collected from the shaker table in 10-ft intervals (fig. 27), three core samples were collected from 4-5-ft long core runs, at 400, 620, and $900 \mathrm{ft}$, with core recovery of 18, 0, and 0 percent, respectively, and rig chatter was recorded in the rig lithologic log (Adam Kojs, USGS, written commun., 2012; fig. 28). Detailed lithostratigraphic component data for NELT5 to a depth of $240 \mathrm{ft}$ are summarized in figure 29. In addition to examining a number of cuttings at various depths, samples were examined that bracket selected changes in geophysical logs near 60, 90, 125, 180, 230, and $295 \mathrm{ft}$. The nearest TEM sounding (NL25) is 50 m west-northwest of the borehole (Burgess and Bedrosian, 2014; fig. 2).

\section{Lithostratigraphic Features and Geophysical Log Data from 50 to $130 \mathrm{ft}$ in NELT5}

Although no detailed examinations of cuttings were made for samples from 0 to $40 \mathrm{ft}$, there are minor changes in gamma values and a sharp decrease in resistivity values at a depth of $40 \mathrm{ft}$. These changes are likely from changes in lithologic characteristics; however, at these depths there are two other possible influencing conditions. Both gamma and resistivity might be influenced by larger borehole diameter (fig. 28). It is likely that there is an important influence on resistivity values in the unsaturated zone from the barometrically driven drying of near surface sediment. In the TEM model resistivity values for NL25, there is a slight trough in resistivity from about 16 to $60 \mathrm{ft}$ (Burgess and Bedrosian, 2014) that is not represented in the borehole data.

From 50 to $60 \mathrm{ft}$, there is an increase in the amount of broken fragments that is consistent with more and (or) larger lithic clasts, and a sharp decrease (from 25 to 15 percent) in the amount of pumice-lithic-rich coatings on lithic clasts. Both samples occur in a series of gamma and resistivity cycles from 20 to $84 \mathrm{ft}$ that have an upward decrease in gamma mean values and an upward increase in resistivity. The upward increase in resistivity, or the downward decrease in resistivity, is probably from barometrically driven drying of near surface sediment.

From 60 to $130 \mathrm{ft}$, there are various trends in lithostratigraphic features that are consistent with the rocks being part of a lithostratigraphic sequence (fig. 29). From 50 to $150 \mathrm{ft}$, various amounts (using descriptors such as numerous, several, and no in figure 29) of polycyclic clasts occur in most samples, and this simply indicates the recycling of lithic clasts from older deposits. From 60 to $130 \mathrm{ft}$, there is a gradational increase in broken fragments and a decrease in original clasts (with a minor disruption in this trend at $120 \mathrm{ft}$ ). From 60 to $130 \mathrm{ft}$, there is a decrease in lithic-rich (detrital, granular textured) coatings from 15 to 1 percent, and most of this decrease is in pumice-lithic-rich coatings. There is only 1 percent of lithic-rich coatings at 60 and $90 \mathrm{ft}$, and none of these coatings at other depths. From 60 to $130 \mathrm{ft}$ tuffaceous coatings typically are on 610 percent of the surfaces in each sample, and for most samples the very fine-grained coating is more abundant than the lithic-bearing coating. At $130 \mathrm{ft}$, tuffaceous coatings are 7 percent, and typically below $130 \mathrm{ft}$, the tuffaceous coatings are less than 6 percent. At $130 \mathrm{ft}$, approximately 2 percent of the samples have calcite rinds on lithic fragments. 
A

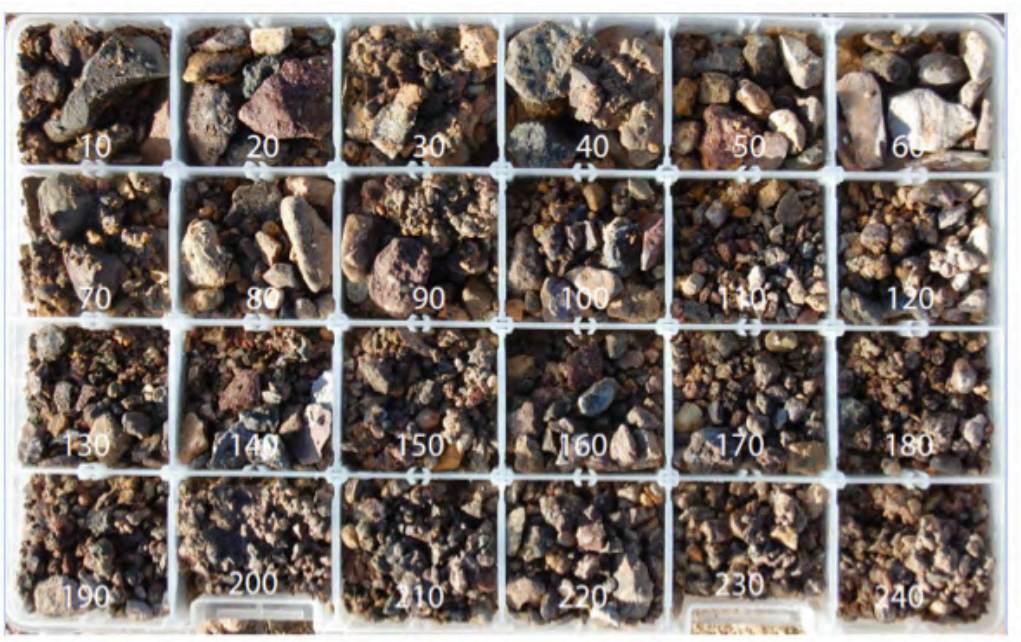

B

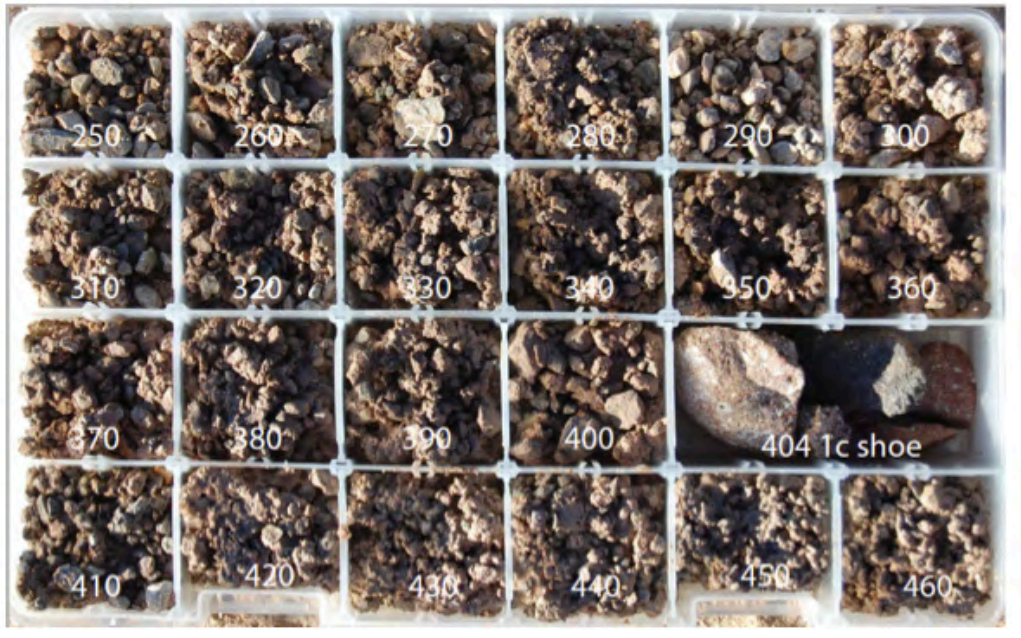

$\mathrm{C}$

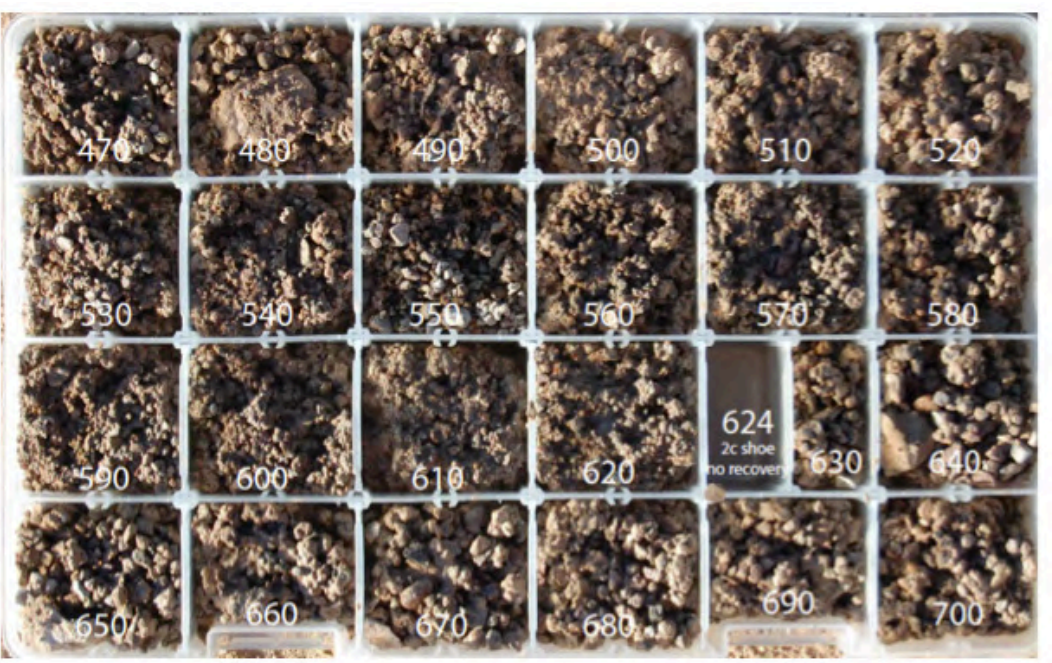

$\mathrm{D}$

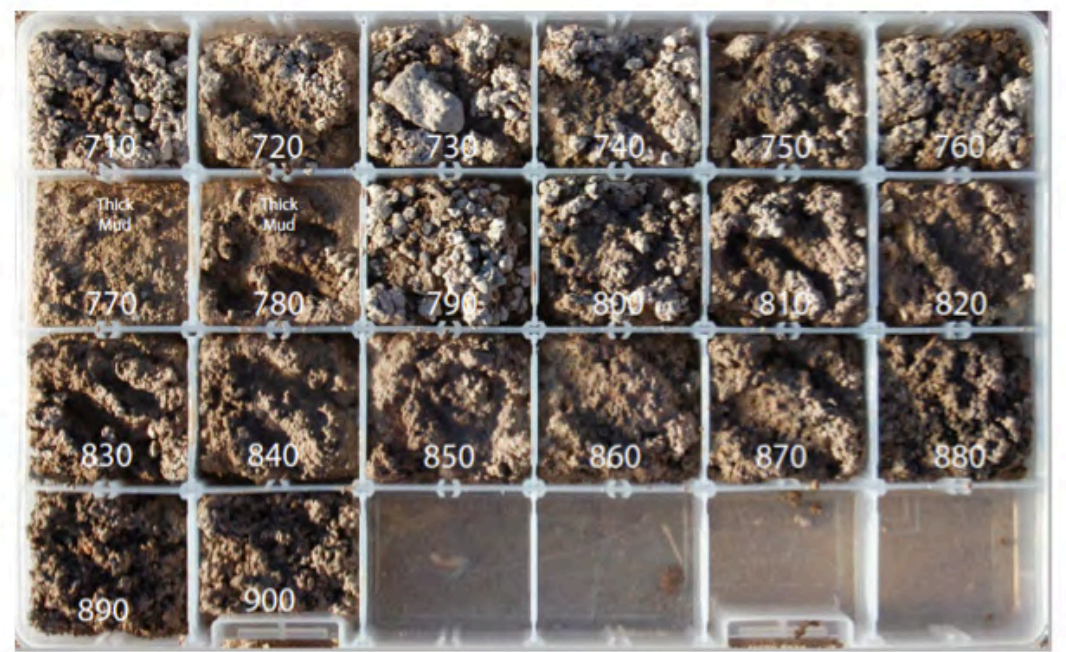

Figure 27. Photographs of cuttings from the shaker table for borehole NELT5 at Fort Irwin, California. $A$, samples from 10 to 240 feet (ft); $B$, samples from 250 to $460 \mathrm{ft} ; C$, samples from 470 to $700 \mathrm{ft} ; D$, samples from 710 to $900 \mathrm{ft}$. Core sample at 404; core runs at 624 and $900 \mathrm{ft}$ had no recovery. A square chip cell is 50×55 millimeters. U.S. Geological Survey photographs by Adam Kojs. 


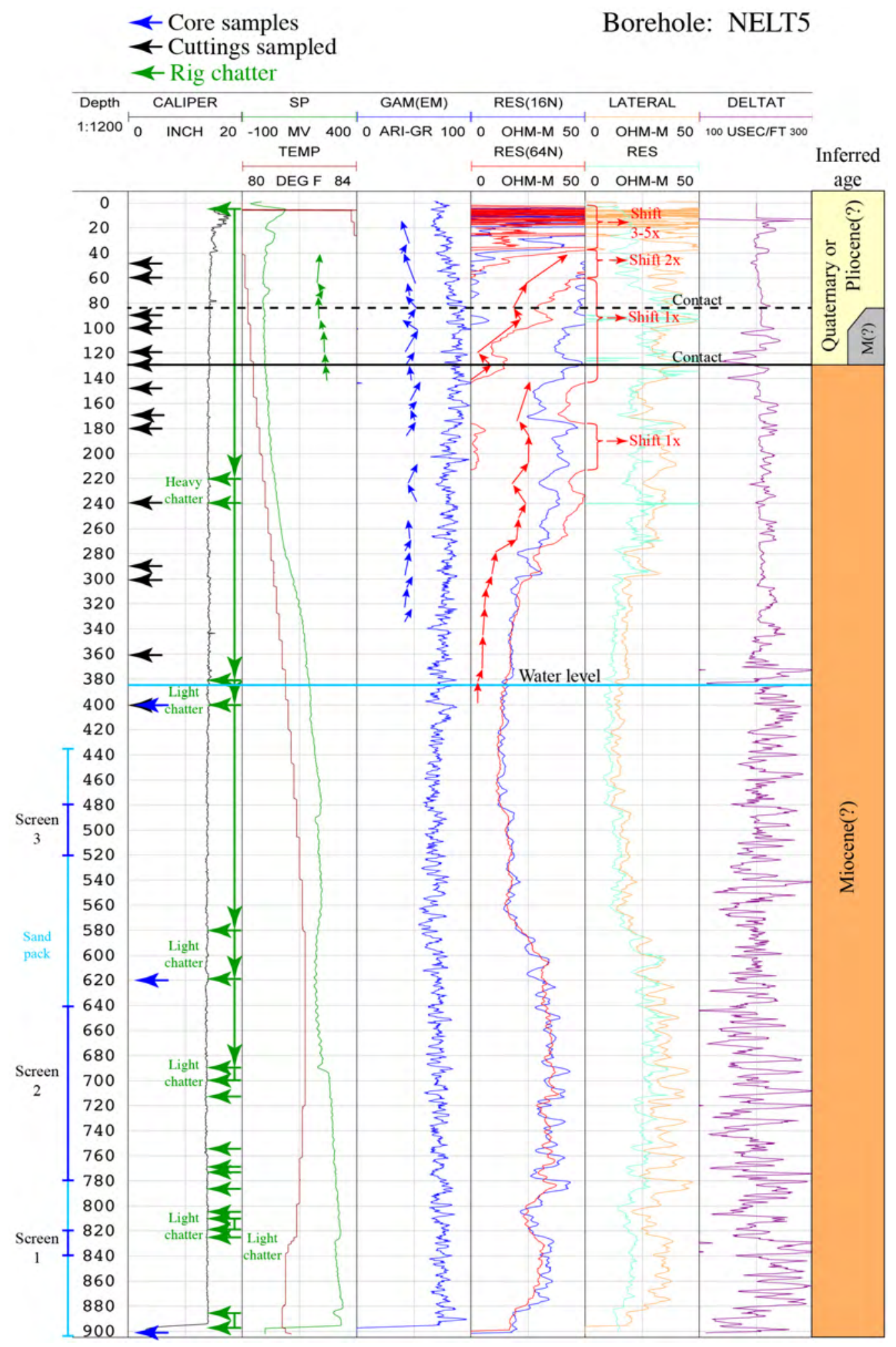

Figure 28. Graph showing locations of cuttings samples in borehole NELT5 at Fort Irwin, California, used for detailed examination compared to core, borehole geophysical logs, rig chatter, and locations of screened intervals 1, 2, and 3 in a single well. 
From 50 to $129 \mathrm{ft}$, gamma and resistivity log data have a number of changes in values and characteristics that result in cycles that are about 10-50 ft thick (fig. 28). As in the other boreholes, cycles consist of a series of waveforms that have wavelength and amplitudes that are the same, increase or decrease, and the mean values of these waveforms are the same, increase or decrease. Many of these cycles have smaller internal cycles. These cycles, and the waveforms that define them, coincide with various minor changes in lithologic features in the cuttings and are consistent with changing deposit types. A few of the depths with more notable changes in the cycles are 64, 84, and $129 \mathrm{ft}$ (fig. 28). Above $64 \mathrm{ft}$, the rocks appear to be sandstone with more lithic-rich coatings (and matrix) at $50 \mathrm{ft}$ to cobbly sandstone with more (lithic-poor and lithicrich) tuffaceous coatings and matrix at $60 \mathrm{ft}$. Both samples occur in several gamma and resistivity cycles beginning at $84 \mathrm{ft}$ that have an upward decrease in gamma mean values and an upward increase in resistivity. From 84 to $129 \mathrm{ft}$, the rocks appear to be conglomerates that vary in apparent maximum lithic sizes or amounts, and the amounts of tuffaceous coatings with minor amounts of interstratified lithic-rich coatings indicate the matrix is mostly tuffaceous but varies with depth. These rocks occur within several gamma cycles. At $84 \mathrm{ft}$, there is a local trough in RES(64N) resistivity at $84 \mathrm{ft}$, and an overall decrease of about $19.1 \mathrm{ohm}-\mathrm{m}$ to the trough at $120 \mathrm{ft}$ with a small (5.4 ohm-m) amplitude peak at $129 \mathrm{ft}$. Below $129 \mathrm{ft}$, there is a continuation of the decrease in resistivity. In the TEM data from NL25, there is a moderately large decrease in minimum-layer model resistivity at $131 \mathrm{ft}$ (Burgess and Bedrosian, 2014).

\section{Lithostratigraphic Features and Geophysical Log Data from 130 to $400 \mathrm{ft}$ in NELT5}

The core at $400 \mathrm{ft}$, of which only 18 percent was recovered, consists of polymictic volcanic clasts that range in diameter from 20 to $70 \mathrm{~mm}$, and no matrix was recovered. The clasts are all crystallized lava flow rock and include a few pieces of andesite(?), but most are dacite or rhyolite. Several clasts have original surfaces that are subrounded to rounded, or slightly planar and slightly smooth to slightly irregular and slightly rough. Most pieces have one or more broken surfaces, and a few have all surfaces broken. It is likely that during drilling, some clasts were broken enough to be removed with all the matrix. Because only 18 percent of the core was recovered, it is likely that clasts larger than $32 \mathrm{~mm}$ (coarse pebble) formed at least 20 percent of the rock. For comparison, the cuttings sample at $400 \mathrm{ft}$ has 65 percent broken surfaces, and this supports the inference that cuttings with large percentages of broken surfaces are probably derived from rocks with large clasts.

In cuttings samples from 150 to $400 \mathrm{ft}$, the fragments are of various crystallized lava flows, with one fragment at $170 \mathrm{ft}$ of a crystallized tuff and a few samples with polycyclic lithic clasts. In the cuttings samples, both the broken lithic fragments and those with original clast sizes and shapes have about the same maximum sizes. The largest fracture surfaces vary from $12 \times 12$ to $18 \times 20 \mathrm{~mm}$, and the largest fragments with all broken surfaces vary from $4 \times 9 \times 12$ to $4 \times 15 \times 20$ $\mathrm{mm}$. The largest clasts with mostly original surfaces vary from $4 \times 9 \times 12$ to $6 \times 11 \times 16 \mathrm{~mm}$, and most clasts less than 3-5 mm (and $8 \mathrm{~mm}$ at $290 \mathrm{ft}$ ) have mostly original surfaces. The similarity in sizes of the maximum broken and original fragments is probably limited by the carrying capacity of the drilling fluid. These data indicate the amounts of broken fragments are representative of the amounts of fragments large enough to break during drilling (and where one clast can result in many fragments). Also, the amounts of original clasts are representative of the abundance of clasts less than $3 \mathrm{~mm}$ to as large as $16 \mathrm{~mm}$ that are in and can be plucked from the matrix of the host rock. From these samples, it appears that samples with greater than 40 percent 
broken fragments are probably more coarse-grained, clast-rich conglomerates, and samples with less than 40 percent broken fragments are probably pebbly to cobbly sandstones.

In the cuttings, there are several apparent trends in the section from 130 to $400 \mathrm{ft}$, with a downward fining sequence from 130 to $180 \mathrm{ft}$, a slight coarsening sequence from 180 to $300 \mathrm{ft}$, a fining sequence from 300 to $360 \mathrm{ft}$, and a coarsening sequence from 360 to $400 \mathrm{ft}$ (fig. 29). In the samples at 150 and $170 \mathrm{ft}$, broken fragments are 55 and 50 percent (respectively), and tuffaceous coatings are 4 and 5 (respectively) with 3 percent pumice-lithic-rich coatings only at $150 \mathrm{ft}$. At $180 \mathrm{ft}$ broken fragments are 40 percent, and tuffaceous coatings are 9 percent with 1 percent pumice-lithic-rich coatings. From 240 to $300 \mathrm{ft}$, the amounts of broken fragments increase from 50 percent at $240 \mathrm{ft}$ to 70 percent at $290 \mathrm{ft}$, and 60 percent at $300 \mathrm{ft}$. The amounts of tuffaceous coatings are similar, and the amount of pumice-lithic-rich coatings decreases from 1 percent at $240 \mathrm{ft}$ to 0 percent in samples deeper than $240 \mathrm{ft}$. From 360 to $400 \mathrm{ft}$, the amounts of broken fragments increase from 35 percent at $360 \mathrm{ft}$ to 65 percent at $400 \mathrm{ft}$. Compared to samples from 290 to $300 \mathrm{ft}$ where the total tuffaceous coatings are 4 and 3 percent (respectively), in samples from 300 to $400 \mathrm{ft}$ the tuffaceous coatings are 8 and 6 percent (respectively); therefore, the section below $300 \mathrm{ft}$ appears to be slightly more tuffaceous, although there are no actual chip fragments of the tuffaceous matrix.

From 129 to $400 \mathrm{ft}$, gamma and resistivity log data have a number of changes in values and characteristics that are consistent with the different types of cycles about 5-50 ft thick (fig. 28). A few of the depths with notable changes in the cycles are 174, 224, 268, and $307 \mathrm{ft}$. At 174 $\mathrm{ft}$, the mean values for gamma and resistivity covary negatively; however, below $174 \mathrm{ft}$ gamma values increase and resistivity values decrease whereas above $174 \mathrm{ft}$ gamma values decrease and resistivity values increase. Resistivity at $174 \mathrm{ft}$ is on the up-borehole side of a broad peak, and above this depth there is the beginning overall increase in resistivity up to the ground surface. These gamma and resistivity values are bounded by the sample at $170 \mathrm{ft}$ that is coarser grained than the sample at $180 \mathrm{ft}$, and has small amounts of tuffaceous coatings. The sample at $180 \mathrm{ft}$ is slightly finer grained than the sample at $170 \mathrm{ft}$, and has approximately double the tuffaceous coatings and has more lithic-bearing tuffaceous coatings (and matrix). At $224 \mathrm{ft}$, the mean values for gamma and resistivity covary positively; however, below $224 \mathrm{ft}$ gamma and resistivity values decrease whereas above $224 \mathrm{ft}$ gamma and resistivity values increase. These gamma and resistivity values are bounded by the samples at 180 and $240 \mathrm{ft}$, and relative to the sample at 180 $\mathrm{ft}$, the sample at $240 \mathrm{ft}$ is slightly coarser grained and has about equal amounts of tuffaceous and lithic-bearing tuffaceous coatings (therefore, probably has a tuffaceous matrix). From 268 to 365 $\mathrm{ft}$ the mean gamma values across several cycles gradually decrease, and from 324 to $371 \mathrm{ft}$ the mean resistivity values across several cycles also gradually decrease. In samples from 290, 300, 360 , and $400 \mathrm{ft}$, there are only very small differences in lithologic features, such as greater amounts of finer grained matrix in an otherwise pebbly to gravelly sequence. For example, the doubling in the amounts of the tuffaceous matrix coatings on lithic clasts from 300 to $360 \mathrm{ft}$ (and the relative increase in lithic-poor tuffaceous coatings in the samples from 360 and $400 \mathrm{ft}$ ) probably indicates that below $307 \mathrm{ft}$ there was more tuffaceous material entrained as detrital grains, and represents slightly different lithofacies in an otherwise alluvial sequence. 
Probably Quaternary to Pliocene(?)

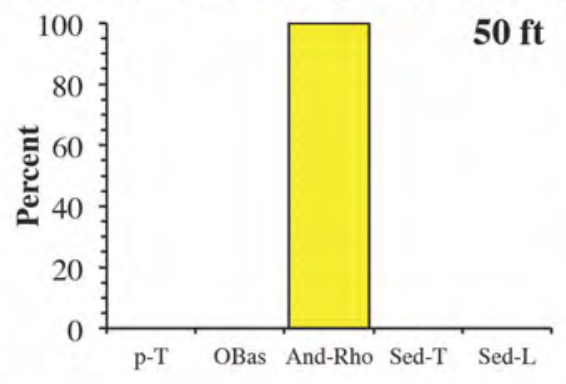

Numerous fragments are polycyclic clasts.

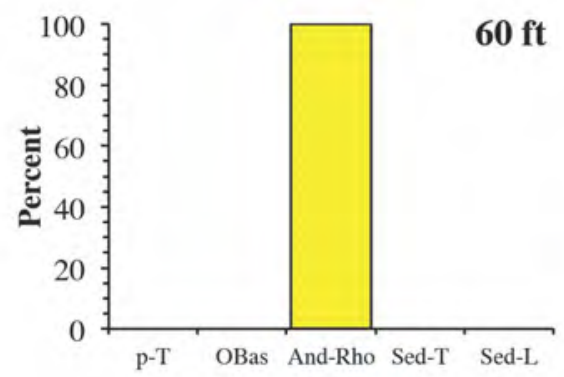

Several fragments are polycyclic clasts.

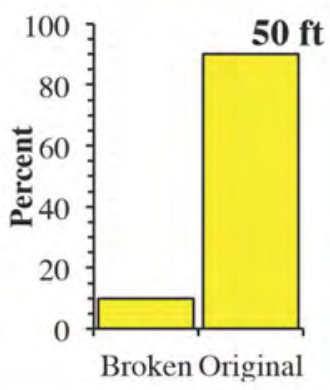

Cross hatched Coat-T is the percent of the lithic-bearing tuffaceous matrix.

Cross hatched Coat- $\mathrm{L}$ is the percent of the pumice-lithic-rich matrix.

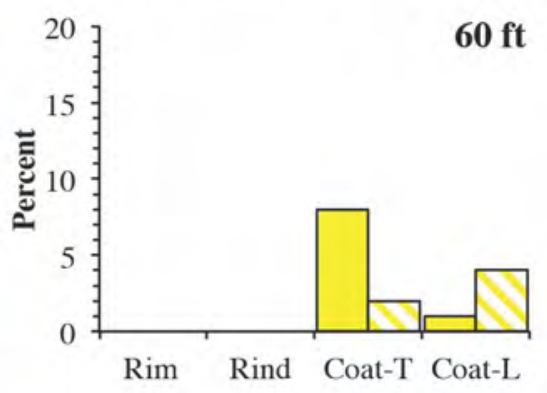

Cross hatched Coat- $\mathrm{T}$ is the percent of the lithic-bearing tuffaceous matrix.

Cross hatched Coat- $\mathrm{L}$ is the percent of the pumice-bearing lithic matrix or pumice-lithic-rich matrix.

\section{Probably Quaternary to Pliocene(?) or Miocene(?)}

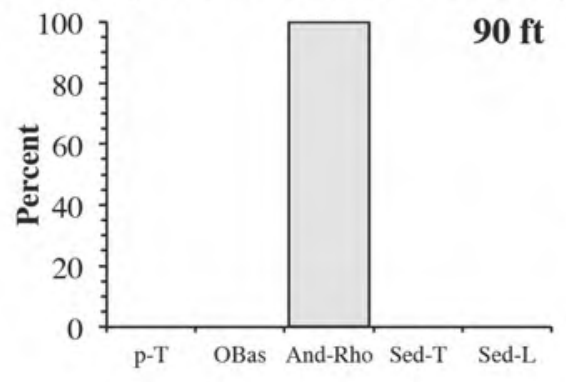

Numerous fragments are polycyclic clasts.

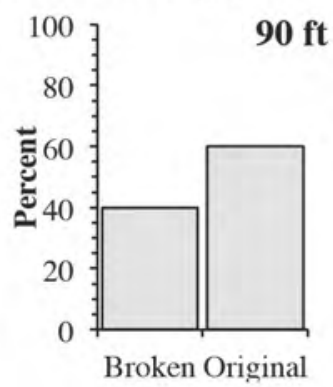

Cross hatched Coat- $\mathrm{L}$ is the percent of the pumice-lithic-rich matrix.

Figure 29. Bar graphs of components of cuttings samples in borehole NELT5 at Fort Irwin, California. Lithologic units: yellow, lithic-rich sediment, probably Quaternary or Pliocene(?); gray, lithic-rich sediment, possibly with tuffaceous matrix, possibly Quaternary to Pliocene(?) or Miocene(?); orange, tuffaceous sediment, probably Miocene(?). Components: p-T, Pre-Tertiary; Obas, porphyritic olivine basalt; And-Rho, andesite to rhyolite; Sed-T, tuffaceous sedimentary rocks, Sed-L, lithic-rich sedimentary rocks; Broken, broken surfaces; Original, original surfaces; Rim, thin layer of crystallization in volcanic rock along a cooling fracture; Rind, calcite, opal, or chalcedony deposits on a lithic clast; Coat-T, tuffaceous coatings; Coat-L, lithic-rich coatings. 

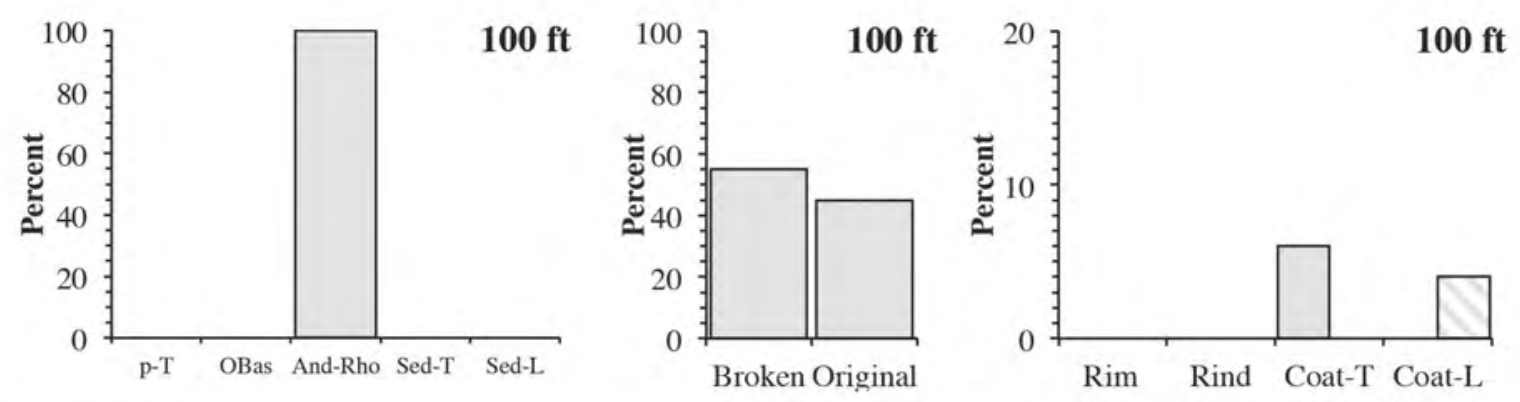

No polycyclic clasts.

Cross hatched Coat- $\mathrm{L}$ is the percent of the pumice-lithic-rich matrix.

The pumice-rich Sed-L coatings are gradational to Sed-T.
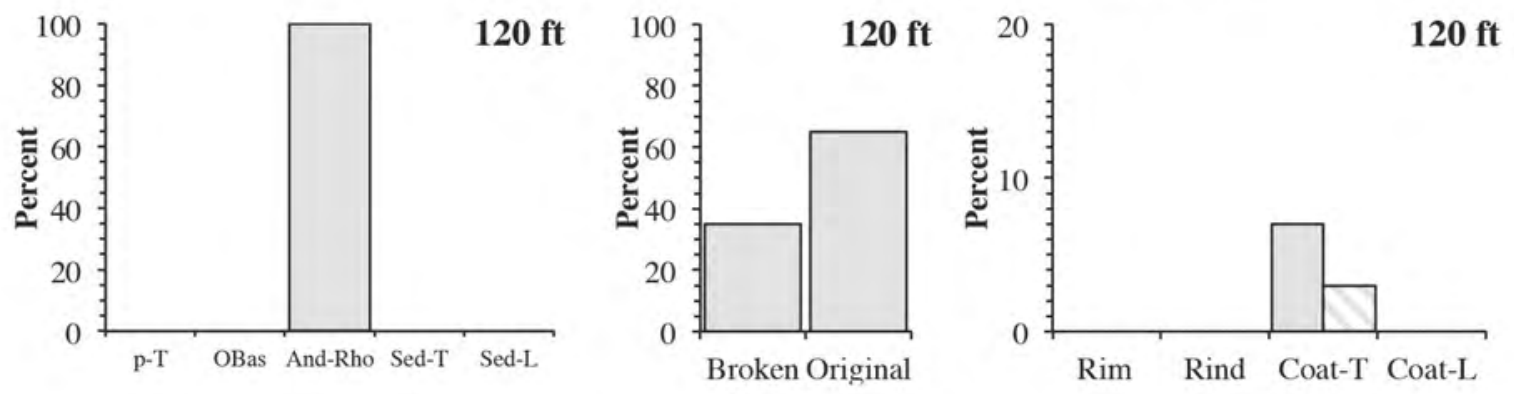

Cross hatched Coat-T is the percent of the lithic-bearing tuffaceous matrix.
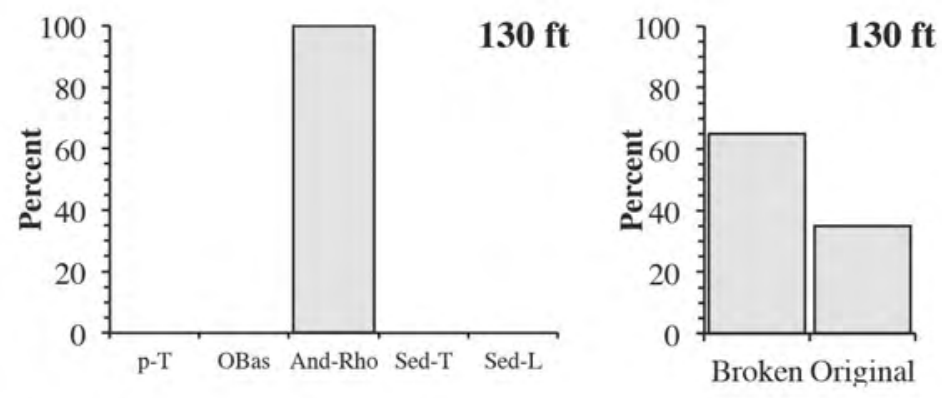

Numerous fragments are polycyclic clasts.

Very heavy rig chatter and long drill time.

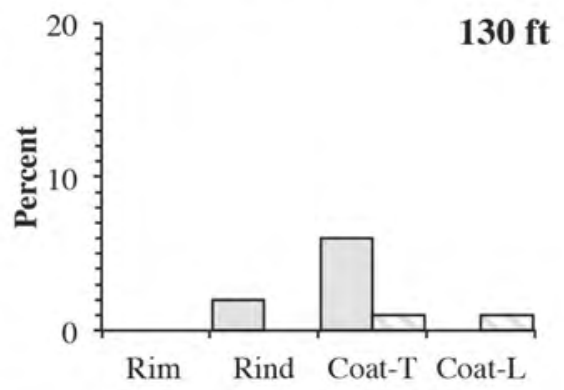

Cross hatched Coat-T is the percent of the lithic-bearing tuffaceous matrix.

Cross hatched Coat-L is the percent of the pumice-lithic-rich matrix.

Figure 29.-Continued 
Probably Miocene(?)

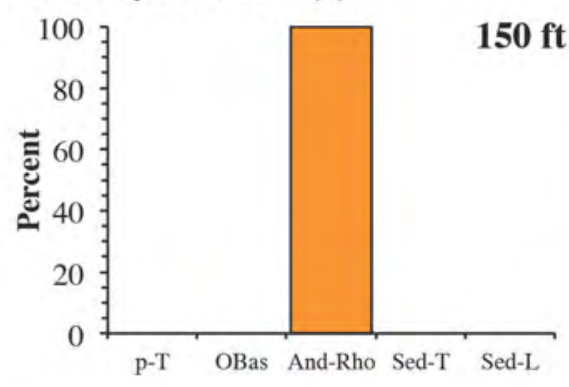

Numerous fragments are polycyclic clasts.

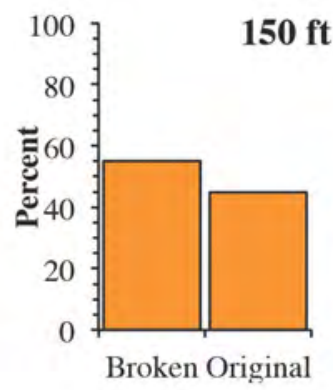

Cross hatched Coat- $\mathrm{L}$ is the percent of the pumice-lithic-rich matrix.

Pumice-lithic-rich matrix is very fine-grained and is transitional to very fine-grained tuffaceous matrix.

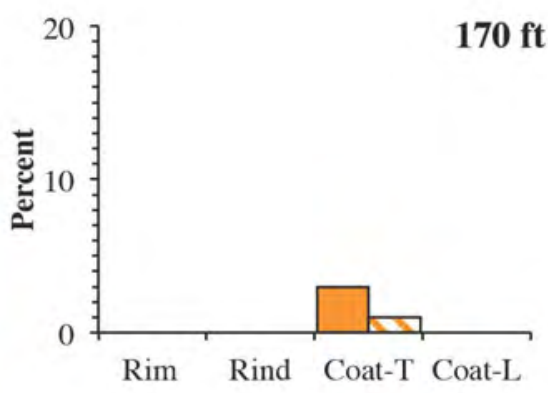

Cross hatched Coat- $\mathrm{T}$ is the percent of the lithic-bearing tuffaceous matrix.
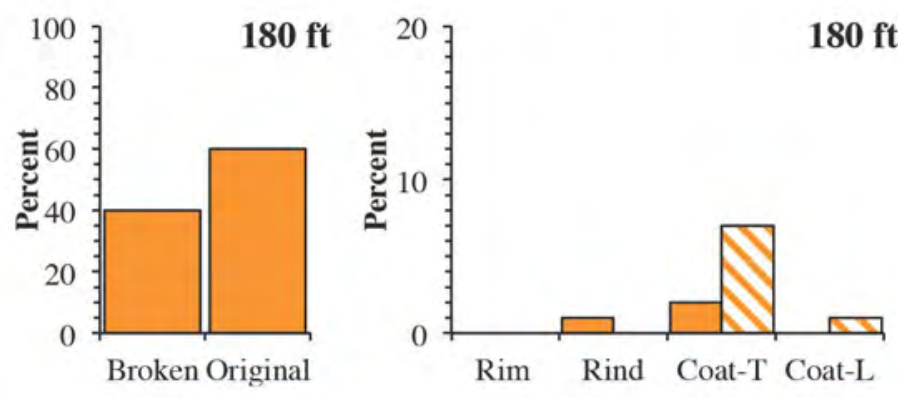

Cross hatched Coat- $\mathrm{T}$ is the percent of the lithic-bearing tuffaceous matrix.

Cross hatched Coat- $\mathrm{L}$ is the percent of the pumice-lithic-rich matrix.

Figure 29.-Continued 

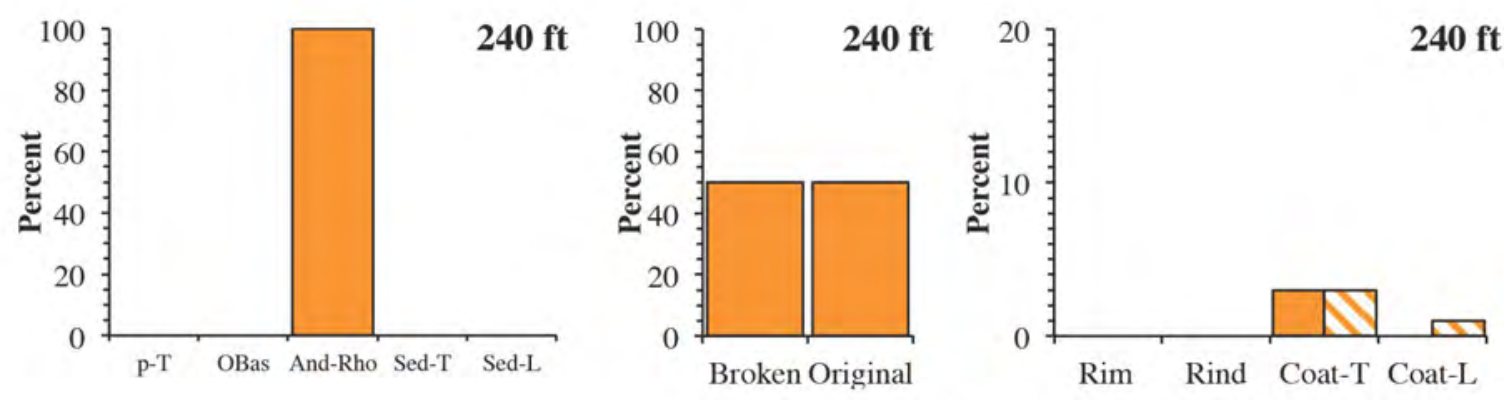

Cross hatched Coat-T is the percent of the lithic-bearing tuffaceous matrix.

Cross hatched Coat- $\mathrm{L}$ is the percent of the pumice-rich lithic matrix.
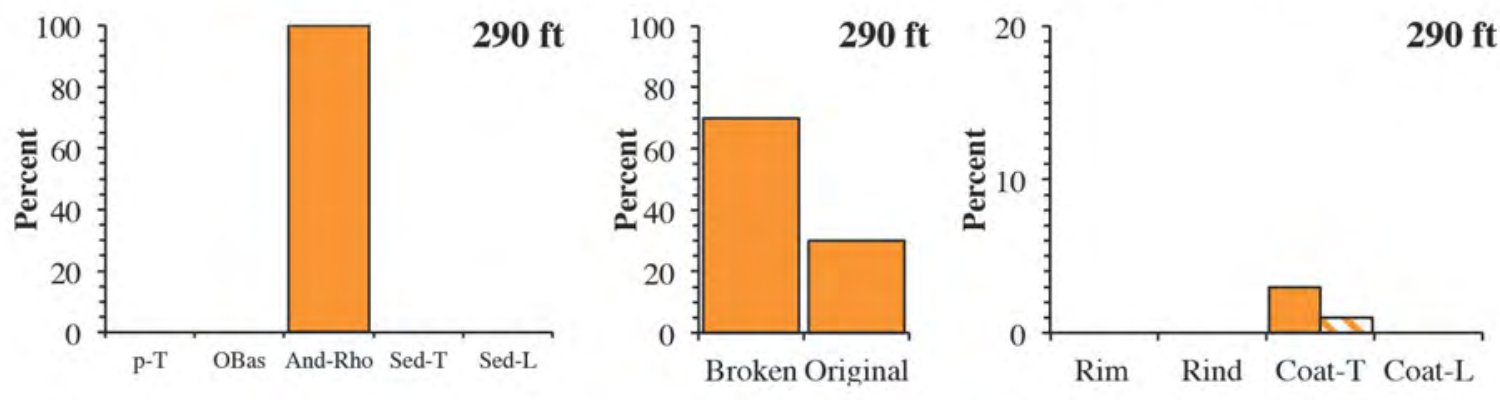

Possibly a few polycyclic clasts.

Cross hatched Coat-T is the percent of the lithic-bearing tuffaceous matrix.
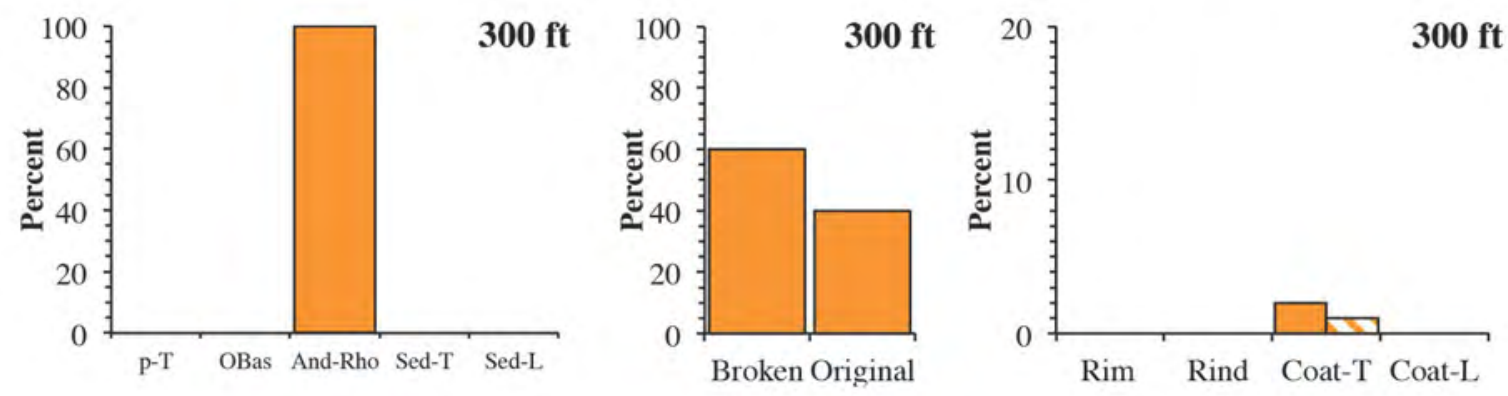

Cross hatched Coat- $\mathrm{T}$ is the percent of the lithic-bearing tuffaceous matrix.

Figure 29.-Continued 


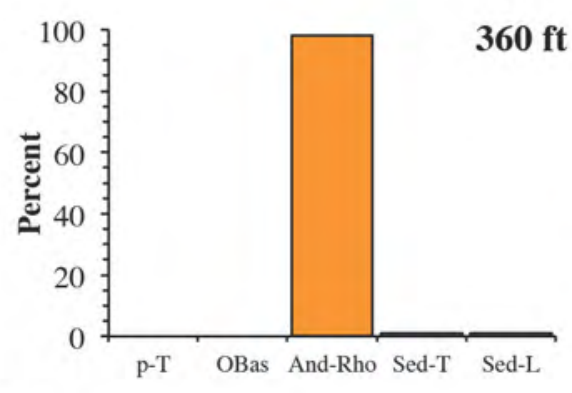

Sed-T are crystallized tuff (not host rock) Sed-L is $1 \%$, but there is only one grain. Numerous fragments are polycyclic clasts.

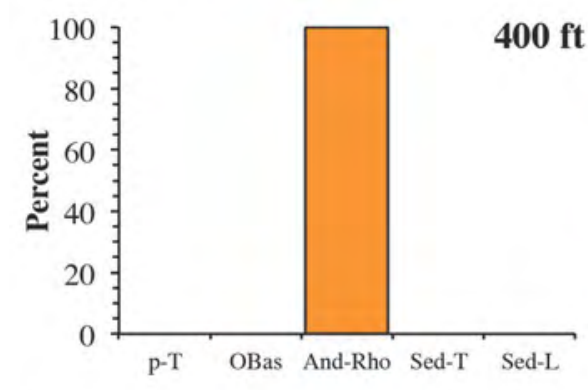

Numerous fragments are polycyclic clasts.
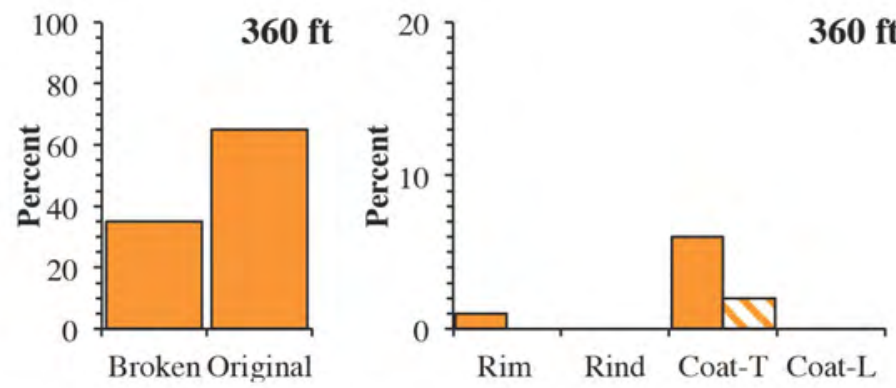

Cross hatched Coat-T is the percent of the lithic-bearing tuffaceous matrix.
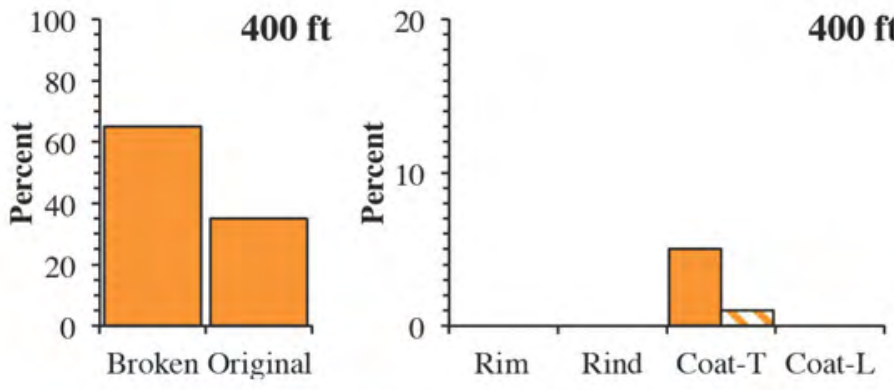

Cross hatched Coat- $\mathrm{T}$ is the percent of the lithic-bearing tuffaceous matrix.

Figure 29.-Continued

Water level is at $384 \mathrm{ft}$, and there is a small (about $3 \mathrm{ohm}-\mathrm{m}$ ) decrease in the average resistivity just above this depth (7 ft thick for RES(16N) and $11 \mathrm{ft}$ for RES(64N)) (Kjos and others, 2014, fig. 28). This decrease in resistivity might represent a capillary fringe above the water level. Several cycles in gamma and resistivity near this depth are consistent with lithostratigraphic beds or bedsets; therefore, the occurrence of the water level at this depth might be locally influenced by property changes in the stratigraphy. Alternatively, the close association of water level and lithostratigraphic property changes could just be a coincidence.

In the TEM data from NL25, there is a moderate decrease in minimum-layer model resistivity at $308 \mathrm{ft}$ and a moderate increase again at $533 \mathrm{ft}$ (Burgess and Bedrosian, 2014). Although the amount of decrease in the TEM model values is much larger than the decrease in resistivity at $295 \mathrm{ft}$ in the borehole, the decrease might be correlated to the increased amount of tuffaceous material in the section below $300 \mathrm{ft}$. The sharp increase in resistivity at $533 \mathrm{ft}$ in the TEM model values is similar to the change in values in the borehole that begins at $562 \mathrm{ft}$.

\section{Summary of Lithostratigraphic Features and Units in Borehole NELT5}

There are no well-defined lithologic nor geophysical data that uniquely define the top of the Miocene(?) section. One reason it is difficult to interpret the types of rocks penetrated in the borehole is that there are no (or only trace amounts) of tuffaceous or lithic-rich sedimentary rock fragments compared to the crystallized volcanic rocks that comprise (almost) all of the cuttings. In the absence of tuffaceous or sedimentary rock fragments, most interpretations are based on the 
coatings on lithic clasts. The amounts of broken lithic fragments are consistent with sandstone to pebbly to cobbly sandstone or conglomerate. The combination of the percent of broken surfaces and types of coatings enables the generalizations that (1) samples with greater than 40 percent broken fragments are probably more conglomeratic, larger grained, and lithic rich with less sandy (and possibly tuffaceous) matrix compared to (2) samples with less than 40 percent broken fragments that probably have fewer clasts with large grain sizes, relatively more (and possibly tuffaceous) matrix, and probably represent pebbly to cobbly sandstones.

Most of the borehole consists of interstratified pebbly sandstone to cobbly conglomerate, and most of these rocks have some form of tuffaceous matrix, although locally there is lithic-rich matrix. The combination of lithostratigraphic components, especially variations in the percent of broken versus original surfaces and types of coatings, and geophysical log cycles results in several variations throughout the stratigraphic section. In the upper $400 \mathrm{ft}$ of the borehole where there are samples, lithostratigraphic trends (or cycles) occur at 50-60, 60-130, 130-180, 180300, 300-360, and 360-400 ft. Throughout the borehole there are many cycles in gamma and resistivity that are 5-50 ft thick, and some of these cycles have nearby cuttings samples (and one core sample) that provide a stratigraphic context for the gamma and resistivity values. Some of the geophysical log cycles that are bounded lithostratigraphic trends have cycle tops at 84, 129, 174, 224, 307, and $365 \mathrm{ft}$. Above $84 \mathrm{ft}$, the rocks appear to be sandstone with more lithic-rich coatings (and matrix) to cobbly sandstone with more (lithic-poor and lithic-rich) tuffaceous coatings and matrix, and both samples occur in several gamma cycles with upward decrease in mean values. Below $84 \mathrm{ft}$, most of the rocks appear to be conglomerates that vary in apparent maximum lithic sizes or amounts, and there is an overall increase in the amount of tuffaceous coatings and matrix with depth. From 129 to $307 \mathrm{ft}$, there are several sets of lithostratigraphic and geophysical log cycles that are consistent with interstratified pebble to cobble conglomerate with mostly tuffaceous coatings and matrix. Based on the similarities of gamma and resistivity cycles from 307 to $365 \mathrm{ft}$, and the increase in lithic-poor tuffaceous coatings between samples at 300 and $360 \mathrm{ft}$, the geophysical log cycle top at $307 \mathrm{ft}$ indicates this interval is mostly pebbly to cobbly sandstone with an increased amount of lithic-poor tuffaceous matrix compared to the rock above this depth. Based on the core and cuttings at $400 \mathrm{ft}$ and the gamma and resistivity cycles below $365 \mathrm{ft}$, these rocks are probably cobbly sandstone to conglomerate with even more lithicpoor tuffaceous matrix compared to the rocks above $365 \mathrm{ft}$.

Lithostratigraphic trends and gamma and resistivity cycles indicate the rocks above $84 \mathrm{ft}$ are pebbly sandstone with tuffaceous and lithic-rich matrix and below $129 \mathrm{ft}$ are conglomerate with mostly tuffaceous matrix. Between 84 and $129 \mathrm{ft}$, the rocks are conglomerates that vary in apparent maximum lithic sizes or amounts, and the amounts of tuffaceous coatings with minor amounts of interstratified lithic-rich coatings indicate the matrix is mostly tuffaceous but varies with depth. At 84 and $129 \mathrm{ft}$, there are small but distinct changes in the gamma cycles. Within a general downward decrease in resistivity, there is a local trough at $84 \mathrm{ft}$, and a local peak at 129 $\mathrm{ft}$. These changes in gamma and resistivity are consistent with local stratigraphic boundaries. Additionally, the sample at $130 \mathrm{ft}$ contains fragments of rinds, and although rinds only occur in a few samples from the boreholes at Fort Irwin, they are consistent with two stratigraphic environments in the unsaturated zone. Calcite rind formation in desert environments tend to form near exposed or buried geomorphic surfaces as (1) on clasts in the shallow unsaturated zone beneath a stable geomorphic surface (caliche horizons), or (2) on clasts near the base of a sedimentary sequence that overlies an unconformity that hydrogeologically results in localized perched water (Neymark and others, 2007). 
The pebbly sandstone with tuffaceous and lithic-rich matrix above $84 \mathrm{ft}$ are interpreted as having been deposited during the inferred Quaternary to Pliocene(?), and the conglomerate with mostly tuffaceous matrix deeper than $130 \mathrm{ft}$ might have been deposited during the inferred Miocene(?) (table 3). The inferred contact at $84 \mathrm{ft}$ includes the main increase in grain size from pebbly sandstone to conglomerate and the increase in tuffaceous matrix. Although the range grain size in the conglomerate does not change significantly beneath $129 \mathrm{ft}$, there is an increase in the amount of tuffaceous matrix and this depth is associated with minor amounts of rind fragments that might be associated with a long-standing geomorphic surface and better developed changes in hydrogeologic properties. So, it is possible that the rocks between 84 and $129 \mathrm{ft}$ can be inferred as Quaternary to Pliocene(?) or Miocene(?) (table 3).

\section{Interpretations for Stratigraphy in NELT6}

Borehole NELT6 is located in the southwestern part of Nelson Lake basin (fig. 2). The borehole is located on intermediate alluvial fan deposits (Quaternary geologic map unit Qia) in an area with young alluvial fan deposits (Qya), older alluvial fan deposits (Qoa), extremely old alluvial fan deposits (early Pleistocene to early Pliocene, QToa, which forms a small knoll 1.7 $\mathrm{km}$ to the northeast), Miocene mafic volcanic rocks (mv, $1.7 \mathrm{~km}$ to the southeast), and Miocene felsic volcanic rocks (fv, $2.6 \mathrm{~km}$ to the southwest) (Miller and others, 2014). The Qia deposits partially fill washes incised into the Qoa, and Qya deposits partially fill washes incised into the Qia and Qoa. Based on erosional relief of Qoa exposures about $2.4 \mathrm{~km}$ south of the borehole, the Qoa is about $25 \mathrm{~m}$ thick, and similar deposits with erosional relief about $2.9 \mathrm{~km}$ northwest of the borehole are estimated to be $15 \mathrm{~m}$ thick. However, neither the top nor bottom of Qoa is exposed in either area, so these are minimum estimates. The Qoa in both locations was deposited on exposures of felsic and mafic volcanic rocks and forms a bajada along the northeastern slopes of these mostly lava flow rocks.

In borehole NELT6, cuttings samples were collected from the shaker table in 10-ft intervals (fig. 30), and three 3-ft-long core samples were collected at 280, 560, and $900 \mathrm{ft}$ with percent core recovery of 77, 92, and 42 percent, respectively (Anthony Brown, USGS, written commun., 2012; fig. 31). Rig chatter was recorded in the rig lithologic log (Joseph Nawakis, USGS, written commun., 2012; fig. 31). The nearest TEM soundings (NL30 and NL4) are 194 and $216 \mathrm{~m}$ (respectively) southwest of the borehole (Burgess and Bedrosian, 2014).

\section{Lithostratigraphic Component Data from 60 to $400 \mathrm{ft}$ in NELT6}

Detailed lithostratigraphic component data for seven sample depths from 60 to $400 \mathrm{ft}$ are summarized in figure 32, and there is very little variation in these samples. Quick evaluations of other samples confirmed the very limited variations identified in the detailed samples. In these seven samples, the fragments are almost entirely crystallized volcanic rocks with one mediumgrained granitic fragment at $60 \mathrm{ft}$, and a few fragments of basalt at 120, 240, and $360 \mathrm{ft}$. Except for a few fragments of slightly altered ignimbrite at $360 \mathrm{ft}$, there are no fragments in any samples of tuffaceous or lithic-rich sedimentary rocks. The large amount of broken surfaces and fragments diminishes the amount of original clast surfaces. There are only 2-4 percent of tuffaceous coatings in each of the samples, and most of these coatings are lithic-poor tuffaceous coatings with about 0.5 percent of lithic-bearing tuffaceous coatings at 60,120 , and $240 \mathrm{ft}$, and 0.5 percent of lithic-crystal-rich coatings at $240 \mathrm{ft}$. The lack of sedimentary rock fragments and minimal amount of coatings result in almost no information as to the possible matrix of the host rock. 
A

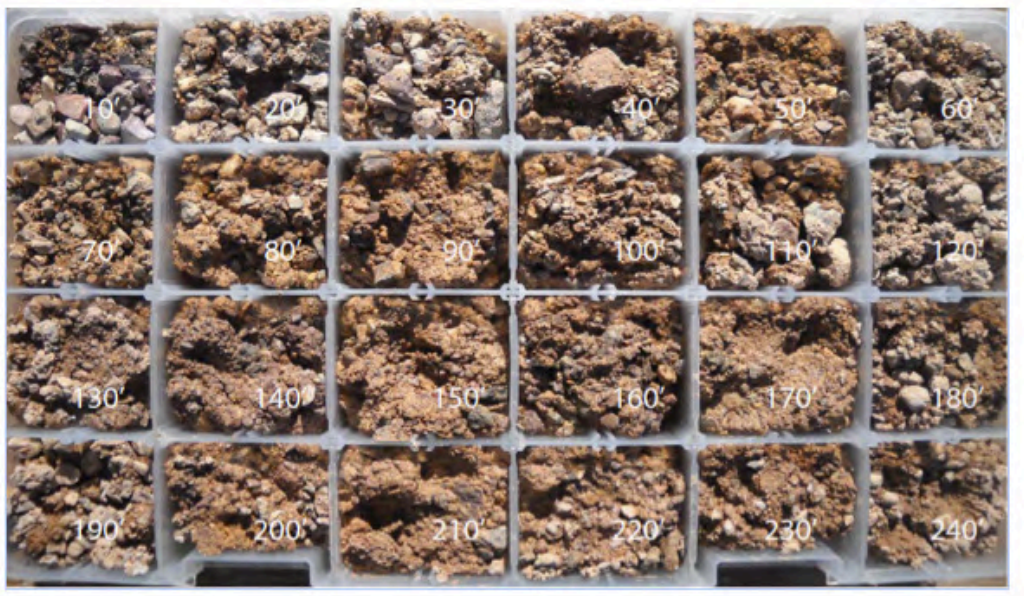

B

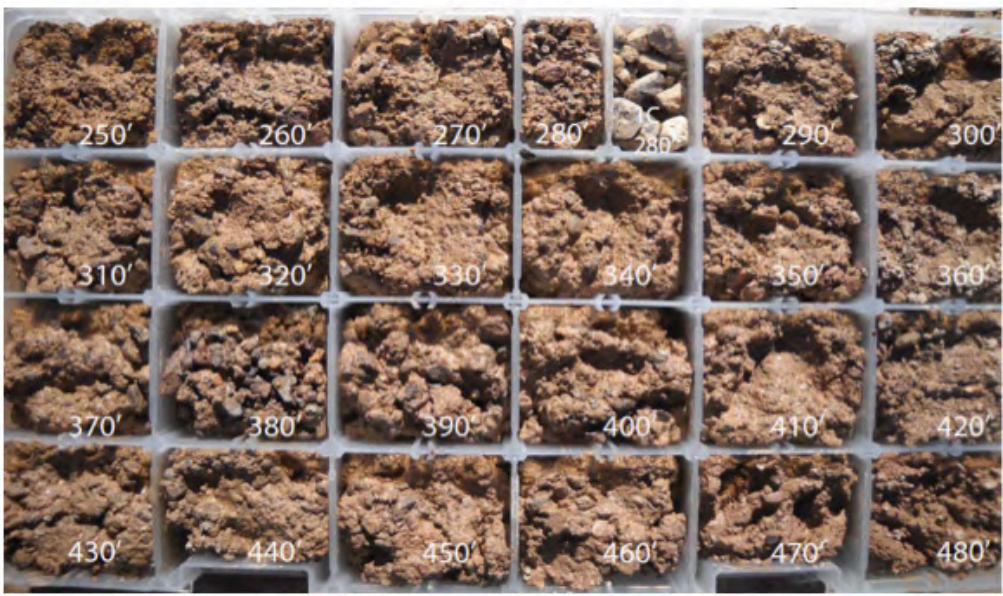

$\mathrm{C}$

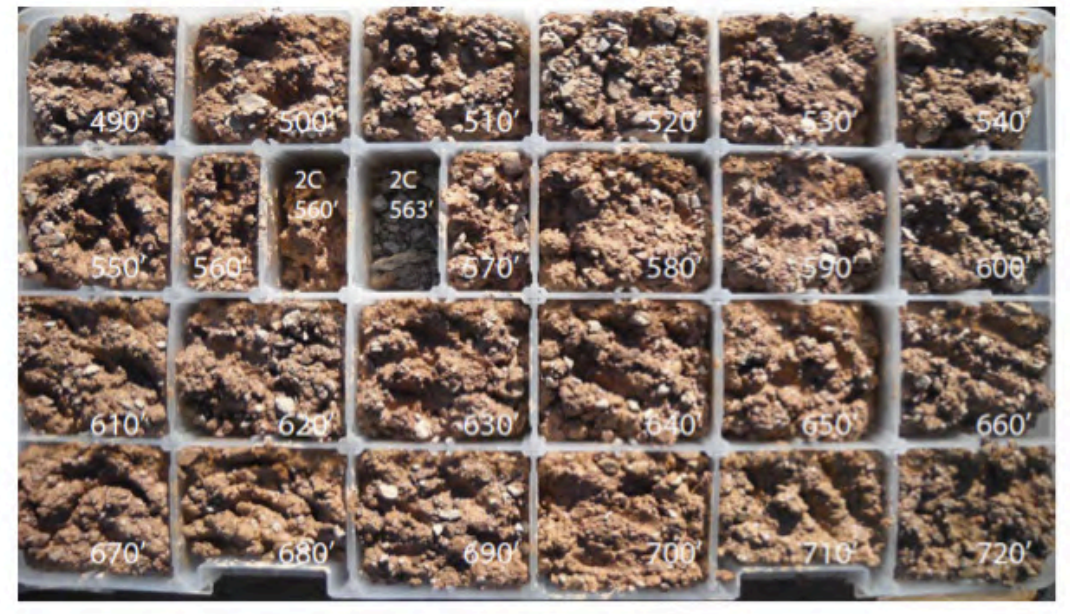

$\mathrm{D}$

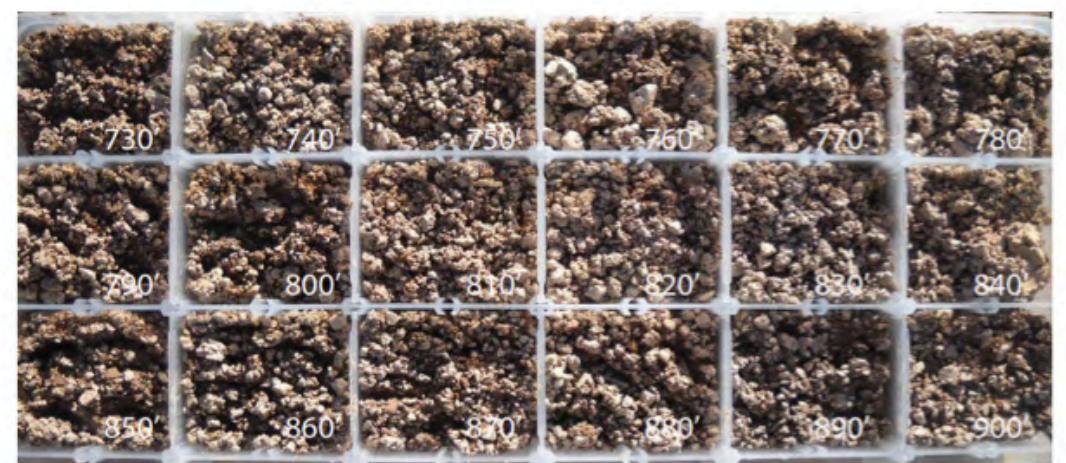

Figure 30. Photographs of cuttings from the shaker table for borehole NELT6 at Fort Irwin, California. A, samples from 10 to 240 feet (ft); $B$, samples from 250 to $480 \mathrm{ft}$; , samples from 490 to $720 \mathrm{ft}$; , samples from 730 to $900 \mathrm{ft}$. Core samples at 283, 563, and $903 \mathrm{ft}$. A square chip cell is $50 \times 55$ millimeters. U.S. Geological Survey photographs by Joseph Nawikas. 


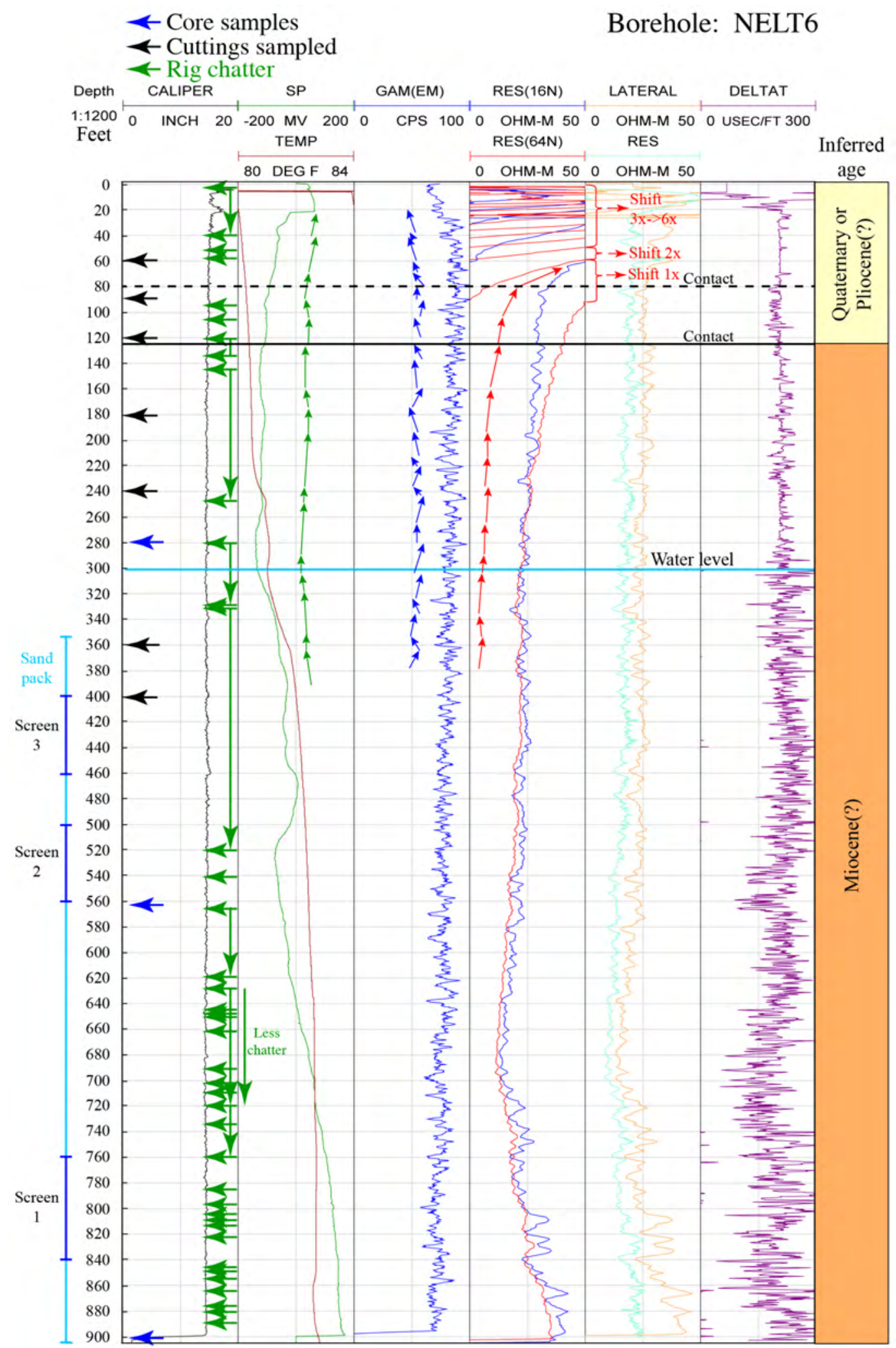

Figure 31. Graph showing locations of cuttings samples in borehole NELT6 at Fort Irwin, California, used for detailed examination compared to core, borehole geophysical logs, rig chatter, and locations of screened intervals 1,2 , and 3 in a single well. 
Broken lithic fragments vary from 60 to 80 percent, the largest fragments with all broken surfaces vary from $2 \times 3 \times 8$ to $3 \times 9 \times 17 \mathrm{~mm}$, and the original size of the fragments cannot be determined from the fragments with at least some original surface. The largest clasts with all original surfaces vary from $5 \times 6 \times 9$ to $9 \times 11 \times 19 \mathrm{~mm}$, and fragments with mostly original surfaces are typically less than $5-8 \mathrm{~mm}$.

The sample at $90 \mathrm{ft}$ differs from these trends, with 30 percent broken fragments and 70 percent original surfaces. The largest clast with all original surfaces is $6 \times 8 \times 12 \mathrm{~mm}$, and fragments with mostly original surfaces are typically less than $10 \mathrm{~mm}$.

The similarity in the sizes of broken and original fragments probably results from the hydrologic equivalency of the fragments to be lifted from the borehole by the drilling fluid. The large amount of broken surfaces indicates that the clasts in the host sedimentary rock are both abundant and relatively large, consistent with the host rock being a conglomerate. There was a lot of rig chatter at $0-40,53-58,96,114,120-136,144-520 \mathrm{ft}$, and intermittently at 563-903 ft (fig. 31), and this is consistent with a significant amount of grinding and breaking of clasts in a lithic-rich conglomerate.

\section{Correlations of Lithostratigraphic Features to Geophysical Data in NELT6}

Geophysical log data for gamma, resistivity, and spontaneous potential have moderate amounts of variations with depth, but none of these data (or combinations of the data) indicate large variations in the stratigraphic sequence in the borehole NELT6 (fig. 31). From 0 to $40 \mathrm{ft}$, the caliper log indicates a slightly enlarged borehole diameter (greater than 1 inch) at two depths that might affect geophysical values. Below $40 \mathrm{ft}$, and especially below $60 \mathrm{ft}$, there are only minor variations in diameter (typically less than 0.5 inch) that probably do not influence the geophysical data. There is a large gradational decrease in resistivity from 0 to $80 \mathrm{ft}$ in resistivity $\log \mathrm{RES}(16 \mathrm{~N})$, and from 0 to $120 \mathrm{ft}$ in resistivity log RES(64N). This decrease probably results from vegetative (evapotranspiration) and barometric drying in the near surface parts of the unsaturated zone (similar to Flint and others [2001], and Flint and others [2002]).

From 30 to $400 \mathrm{ft}$, there are a number of depths where two or more of the geophysical logs have changes in values (or in the characteristics in the values) that might be correlated to changes in lithostratigraphic features. These depths include 41, 60, 79, 89, 104, 124, 136, 159, 193, 216, 236, 264, 304, 324, 336, 353, and $379 \mathrm{ft}$. There are sharp general decreases in both resistivity log values from 30 to $82 \mathrm{ft}$. Within this trend, at 60 and $82 \mathrm{ft}$ the RES(16N) resistivity values have a small increase, and at $124 \mathrm{ft}$, there is a small increase. Below $120 \mathrm{ft}$, the resistivity has a general trend of decreasing values that continues to about $336 \mathrm{ft}$. From 82 to $336 \mathrm{ft}$, in all the log data, there are a series of poorly defined cycles that vary from 5 to $40 \mathrm{ft}$ thick. In the resistivity values, the top of each cycle has larger values that decrease to smaller values within each cycle, and the amplitude of each successive cycle decreases with increasing depth. There are more and shorter cycles in gamma than in spontaneous potential, but there are numerous depths where changes in gamma and spontaneous potential values (or characteristics) do coincide with tops of the cycles in resistivity, although these changes are not consistent in occurrence, magnitude, or direction.

The water level was identified at $301 \mathrm{ft}$ (fig. 31), and although there is a slight change in values (and characteristics of the values) for all three logs at this depth, the change is small compared to the variations in the data both above and below this depth. These small changes at water level indicate that the water level cannot be easily identified (or separated from) variations based on lithostratigraphic properties. Some of the depths where geophysical log values change 
are closely associated with or bounded by samples used for the detailed component analysis (at $60,120,180,240,360$, and $400 \mathrm{ft}$ ); however, these cuttings samples do not have enough distinctive and detailed variations to provide constraints to the geophysical data. There are slight variations in the borehole geophysical log data from 400 to $900 \mathrm{ft}$; however, cuttings samples were not analyzed during this study.

In TEM sounding NL30, there are small to moderate decreases in the minimum-layer resistivity at 60 and $118 \mathrm{ft}$ (Burgess and Bedrosian, 2014). In TEM sounding NL4, there are very small decreases in the minimum-layer resistivity at 20 and $315 \mathrm{ft}$ (Burgess and Bedrosian, 2014). The amounts of these decreases in resistivity in the TEM differ from those measured in the borehole, but the depths where there are decreases in the TEM minimum-layer resistivity are reasonably consistent with changes in the borehole. Although, Burgess and Bedrosian (2014) did not do as much with the best-fit smooth inverse model, several of the variations in modeled resistivity have good fits with the borehole resistivity cycles.

\section{Summary of Lithostratigraphic Features and Units in Borehole NELT6}

In borehole NELT6, the minimal variation in lithostratigraphic features in the cuttings samples and the minor variations in geophysical log values make it difficult to identify lithostratigraphic units and contacts, let alone the possibility of identifying a contact between rocks of inferred Quaternary to Pliocene(?) and inferred Miocene(?) age. The lack of sedimentary rock fragments and minimal amount of coatings supports the inference that the matrix (even to depths of $400 \mathrm{ft}$ ) is poorly lithified and easily disaggregated during drilling. In the relatively shallow depths from 60 to $180 \mathrm{ft}$, there are several small changes in geophysical log data; however, cuttings samples from 60, 120, and $180 \mathrm{ft}$ are all very similar and indicate very little change in lithostratigraphic characteristics at these depths. If the apparent cycles depicted in the resistivity data are indicative of lithostratigraphic variations in sedimentary sequences, then the shallowest of these cycles and sequences can be identified at $124 \mathrm{ft}$ (and possibly $79 \mathrm{ft}$ ) (table 3). If cyclic sedimentary sequences can be traced (as represented by resistivity data) from depth to $124 \mathrm{ft}$, then these rocks are probably from the sequences deposited during the inferred Miocene(?), and the rocks shallower than $124 \mathrm{ft}$ are probably from sequences deposited during the inferred Quaternary to Pliocene(?) (table 3). 


\section{Probably Quaternary to Pliocene(?)}

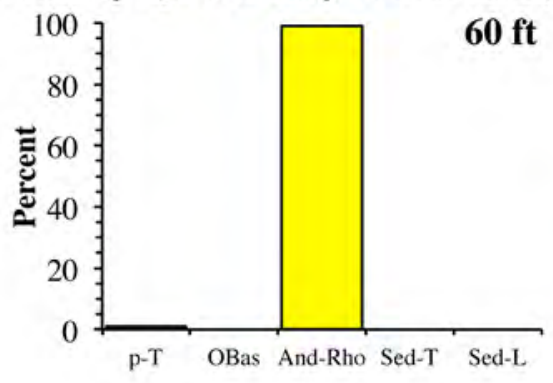

$\mathrm{p}-\mathrm{T}$ is a medium-grained granite

Numerous fragments are polycyclic clasts.

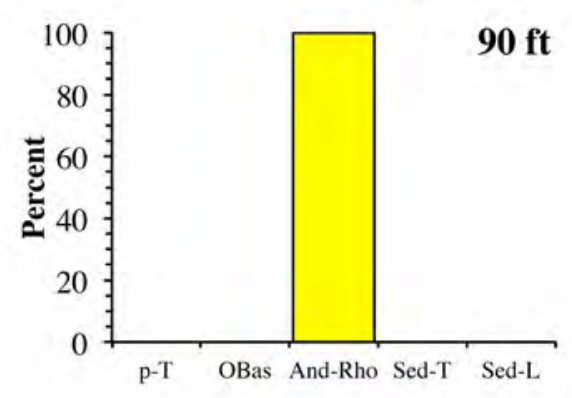

Numerous fragments are polycyclic clasts.

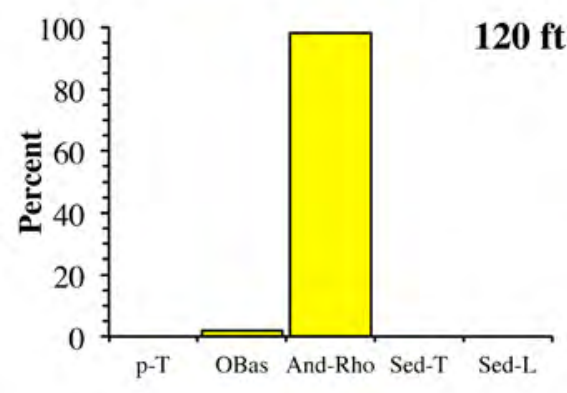

OBas is probably andesitic basalt

Numerous fragments are polycyclic clasts.
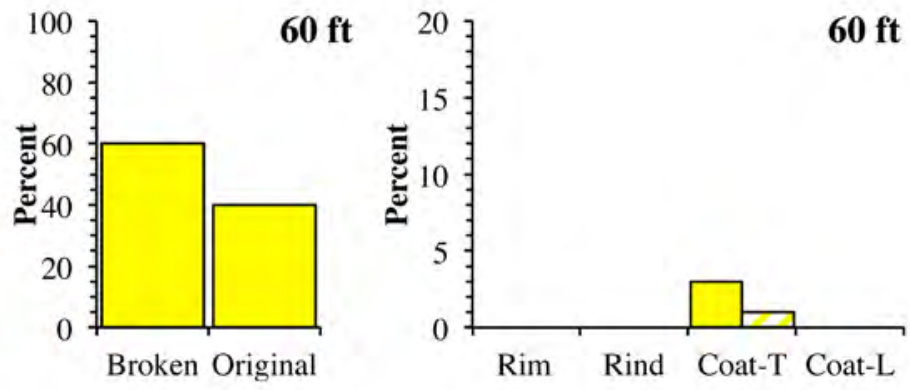

Cross hatched Coat- $T$ is the percent of the lithic-bearing tuffaceous matrix.
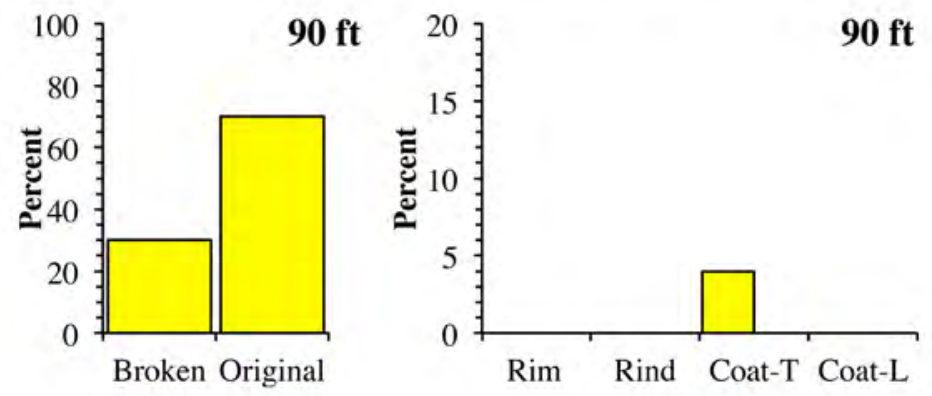

Figure 32. Bar graphs of components of cuttings samples in borehole NELT6 at Fort Irwin, California. Lithostratigraphic units: yellow, lithic-rich sediment, probably Quaternary or Pliocene(?); orange, tuffaceous sediment, probably Miocene(?). Components: p-T, pre-Tertiary; Obas, porphyritic olivine basalt; And-Rho, andesite to rhyolite; Sed-T, tuffaceous sedimentary rocks, Sed-L, lithic-rich sedimentary rocks; Broken, broken surfaces; Original, original surfaces; Rim, thin layer of crystallization in volcanic rock along a cooling fracture; Rind, calcite, opal, or chalcedony deposits on a lithic clast; Coat-T, tuffaceous coatings; Coat-L, lithic-rich coatings. 


\section{Probably Miocene(?)}
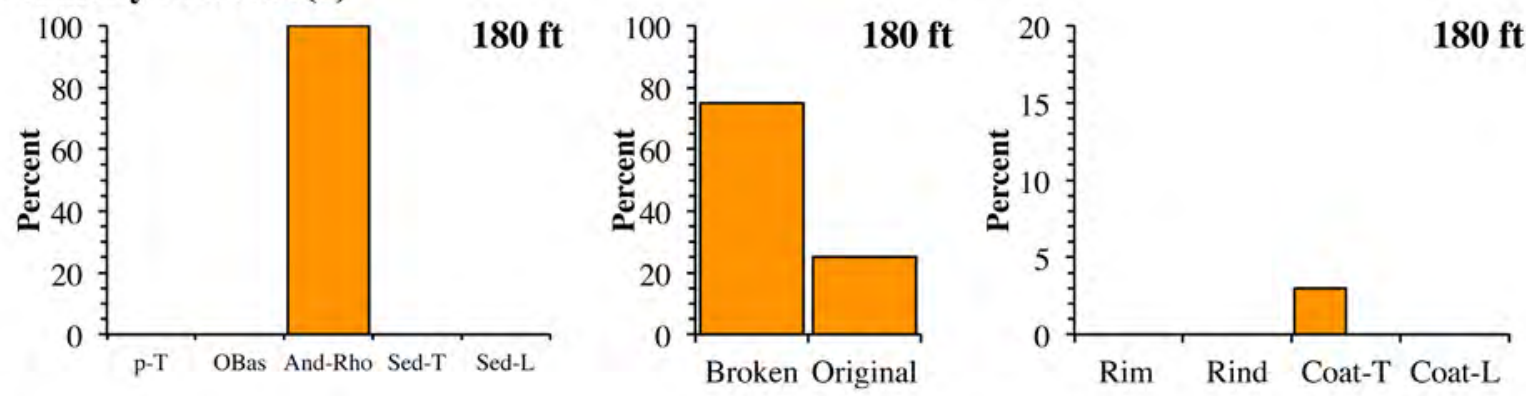

Few fragments are polycyclic clasts.
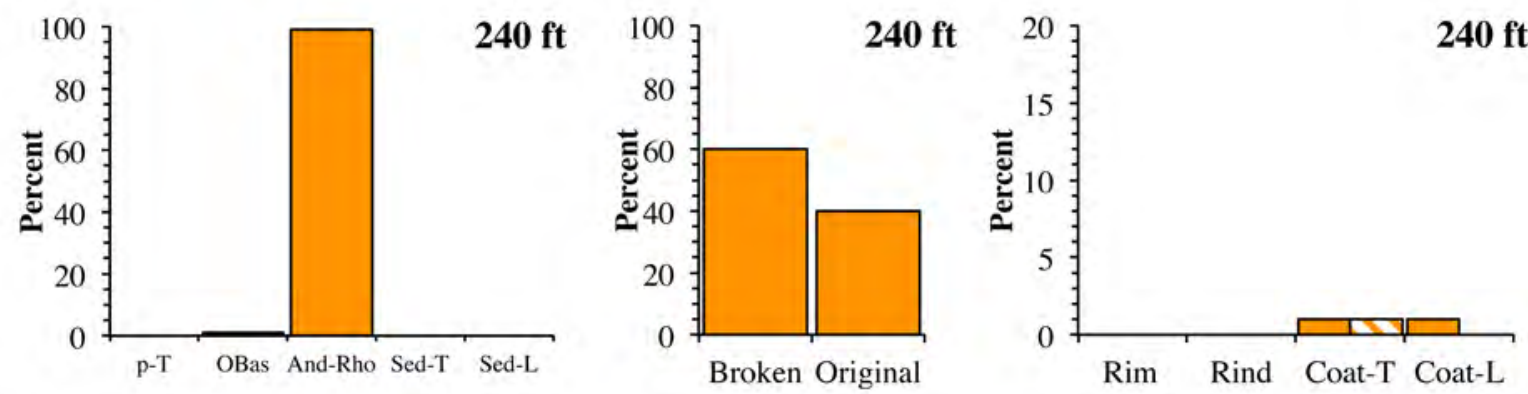

OBas is probably andesitic basalt

Very few fragments are polycyclic clasts.
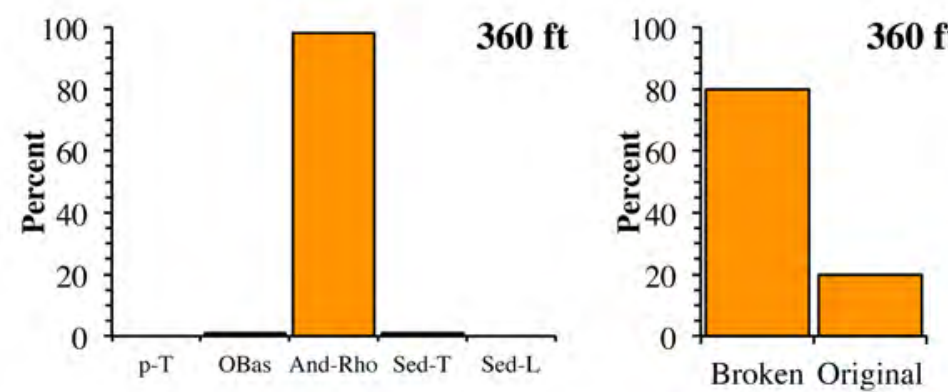

Cross hatched Coat- $\mathrm{T}$ is the percent of the lithic-bearing tuffaceous matrix.

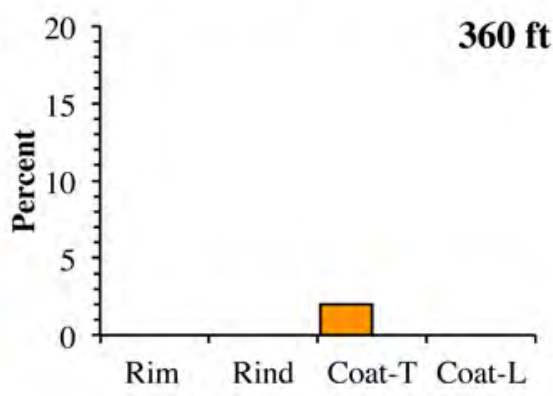

OBas is probably andesitic basalt

Sed-T is white, slightly altered ignimbrite

Very few fragments are polycyclic clasts.
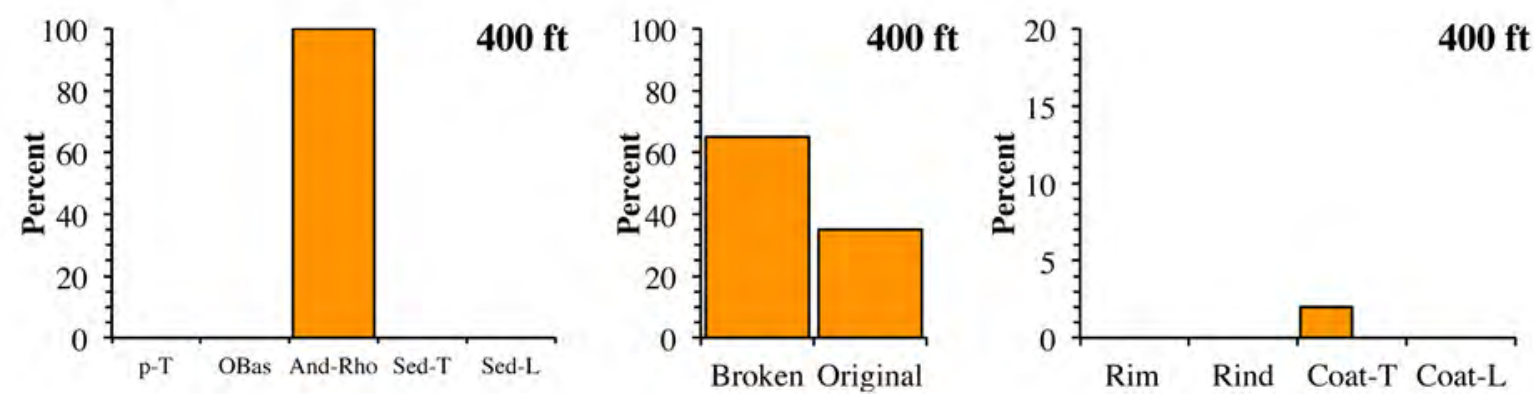

Very few fragments are polycyclic clasts.

Figure 32.-Continued 


\section{Interpretations for Stratigraphy in NELT7}

Borehole NELT7 is located $2 \mathrm{~km}$ south of McLean Lake in the Nelson Lake basin. The borehole is on a $070^{\circ}$ trending, low-relief topographic divide developed in young alluvial fan deposits (Holocene and latest Pleistocene with map symbol Qya), and just north of a low-relief ridge formed by deformation along an east-striking fault about midway between the Nelson Lake and McLean Lake Faults (Miller and others, 2014). This part of the basin is bounded to the northwest by mafic volcanic rocks (mv, which include basalt, andesite, and dacite), and to the northwest to east by mostly Cretaceous, felsic, grus-forming plutonic rocks (fpg). Locally there are a variety of Quaternary alluvial fan deposits from young (Qya) to extremely old (QToa), some of which are fans composed of grus.

In borehole NELT7, cuttings samples were collected from the shaker table in 10-ft intervals (fig. 33), and 3-ft-long core samples were collected at 280 and $520 \mathrm{ft}$ and a 5-ft core at $860 \mathrm{ft}$ with core recovery of 94, 77, and 13 percent, respectively (Joseph Nawikas, USGS, written commun., 2012; fig. 34). Detailed component data for NELT7 to a depth of $240 \mathrm{ft}$ are summarized in figure 35. There are two TEM soundings near NELT7; NL18 is $742 \mathrm{~m}$ to the eastnortheast, and NL10 is $1.6 \mathrm{~km}$ to the northwest (Burgess and Bedrosian, 2014).

\section{Lithostratigraphic Features and Geophysical Log Data from 50 to $86 \mathrm{ft}$ in NELT7}

From 50 to $80 \mathrm{ft}$, 44-57 percent of the fragments are pre-Tertiary granitic, 40-45 percent are mostly crystallized volcanic (andesitic to rhyolitic) rocks, 5-15 percent are pumice-lithic-rich sandstone with detrital tuffaceous matrix (with only 1 percent at $80 \mathrm{ft}$ ), and only $0-1$ percent are fragments of tuffaceous material. Broken surfaces comprise 5-15 percent of the fragments, where the maximum size of broken pieces varies from $6 \times 12 \times 12$ to $7 \times 9 \times 18 \mathrm{~mm}$. The maximum size of clasts (with most or all original surfaces) varies from $4 \times 9 \times 11$ to $5 \times 8 \times 17 \mathrm{~mm}$. Rinds occur on $0-2$ percent of the fragments. About 15-22 percent of the lithic clasts have coatings where 820 percent are pumice-lithic-rich matrix, $0-1$ percent are lithic-rich matrix, and 1 percent are tuffaceous (lithic poor) matrix (fig. 35; table 2.1).

From 0 to $86 \mathrm{ft}$, there are several variations in the gamma, resistivity, and spontaneous potential geophysical logs (fig. 34), and all three change at about $86 \mathrm{ft}$. From 8 to $86 \mathrm{ft}$, there are numerous small (4-14 ft wavelength) cycles in gamma values; however, each cycle has a downhole increase in mean values, and this forms a larger complex cycle from 8 to $86 \mathrm{ft}$ with an overall increase in mean values. From 0 to $40 \mathrm{ft}$, resistivity values decrease sharply, and this probably results from vegetative (evapotranspiration) and barometric drying of shallow sedimentary rocks, (similar to Flint and others [2001], and Flint and others [2002]). Barometric drying probably continues to influence the resistivity down to the standing water level. From 40 to $65 \mathrm{ft}$, there are relatively high, (but a local low) values of resistivity that gradationally increase, and values of spontaneous potential that gradationally increase. At $65 \mathrm{ft}$, there is a sharp increase of resistivity values, and peak spontaneous potential values. From 65 to $86 \mathrm{ft}$, resistivity continues to be high, but there is a local low at $72 \mathrm{ft}$, a peak at $80 \mathrm{ft}$, and a narrow but large low at $86 \mathrm{ft}$. From 65 to $86 \mathrm{ft}$, there is a decrease in spontaneous potential.

In the TEM minimum-layer model resistivity in NL18, there are no changes from 0 to $178 \mathrm{ft}$, but at $178 \mathrm{ft}$ there is a small decrease in resistivity, and in NL10, there are no changes from 0 to $100 \mathrm{ft}$, but at $100 \mathrm{ft}$ there is an increase in resistivity (Burgess and Bedrosian, 2014). The fixed-thickness, 20-layer model resistivity values from both NL18 and NL10 are slightly more varied in values. In NL18, there is a slight peak at $35 \mathrm{ft}$, a trough at $88 \mathrm{ft}$, and a peak at 150 
$\mathrm{ft}$; and in NL10, there is a peak at $41 \mathrm{ft}$, a slight trough at $62 \mathrm{ft}$, and a peak at $150 \mathrm{ft}$. In several other boreholes at Fort Irwin, the variations in resistivity are reasonably correlated to the TEM models; however, it is not quite clear why the NELT7 borehole and TEM model resistivity values are not more similar.

\section{Lithostratigraphic Features and Geophysical Log Data from 86 to $280 \mathrm{ft}$ in NELT7}

Based on the lithostratigraphic features such as types of fragments, amount of broken fragments, and coatings on lithic clasts, there appear to be several lithostratigraphic cycles with samples at 80,160,180, 210, and $240 \mathrm{ft}$ as the beginning of the cycles. There are also subcycles within these trends. Geophysical log data indicate several cycles that appear to correlate with the lithologic trends. The depth of $280 \mathrm{ft}$ for these descriptions is based on the core sample.

From 80 to $140 \mathrm{ft}$, there is a decrease in pre-Tertiary granitic fragments, and from 80 to $160 \mathrm{ft}$, there is a gradational decrease in the amounts of broken fragments along with a gradational increase in the amounts of tuffaceous coatings. At $80 \mathrm{ft}$, most of the fragments are granitic or lithic volcanic (57 and 40 percent, respectively); however, compared to the sample at $70 \mathrm{ft}$, there is a sharp decrease in pumice-lithic-rich sandstone, and there are small amounts of pumice tuff with clay(?)-altered matrix and basalt fragments. From this depth of $80 \mathrm{ft}$ and deeper, the amounts of tuffaceous and lithic-rich sandstone are typically 0-3 percent. Basalt fragments are 1 percent in samples from 80 to $160 \mathrm{ft}$, 0 percent at $120 \mathrm{ft}$, and 2 percent at $140 \mathrm{ft}$. From 80 to $120 \mathrm{ft}$, there is a gradational decrease in the amount of granitic fragments, and from 120 to $160 \mathrm{ft}$, there is a gradational increase in granitic fragments. Compared to the sample at 70 $\mathrm{ft}$, at $80 \mathrm{ft}$ there is a sharp decrease (to 8 percent) in the amount of pumice-lithic-rich coatings, and a slight increase (to 6 percent) in the amount of tuffaceous coatings (both tuffaceous and crystal-bearing tuffaceous matrix). From 80 to $120 \mathrm{ft}$, there is a gradational increase in the amounts of tuffaceous coatings, and this is partitioned between a slightly larger increase in the tuffaceous coatings and a slight decrease in the crystal-bearing tuffaceous coatings. These trends in coatings continue as deep as $160 \mathrm{ft}$, with one possible variation at $140 \mathrm{ft}$ where the total percent of coatings is less than other samples; however, the relative amounts of the various coatings at $140 \mathrm{ft}$ are consistent with other samples.

From 160 to $240 \mathrm{ft}$, there are three lithostratigraphic cycles; however, these cycles are not simple and the details are consistent with more than one provenance. From 160 to $180 \mathrm{ft}$, there is a decrease in pre-Tertiary granitic fragments, a slight increase in the amount of broken fragments, and the beginning of a decrease in coatings on lithic clasts. From 180 to $240 \mathrm{ft}$, there are two lithostratigraphic cycles; however, using the type and amount of fragments, the sample at the boundary of the cycles is at $230 \mathrm{ft}$, and using the amount of broken fragments, the boundary is at $210 \mathrm{ft}$.

From 180 to $230 \mathrm{ft}$, there is an increase in the number of granitic fragments, and from 230 to $240 \mathrm{ft}$, there is a slight decrease. From 180 to $210 \mathrm{ft}$, there is a decrease (from 10 to 5 percent) in the number of broken fragments, and from 210 to $240 \mathrm{ft}$ there is a slight increase (from 5 to 15 percent). At 180 and $210 \mathrm{ft}$, clasts with mostly original surfaces are about 10 and $16 \mathrm{~mm}$ in diameter (respectively), and at $230 \mathrm{ft}$, clasts with mostly original surfaces are about 5 $\mathrm{mm}$; therefore, the matrix material at 180 and $210 \mathrm{ft}$ appears to have slightly larger grain sizes compared to the matrix at $230 \mathrm{ft}$. 
A

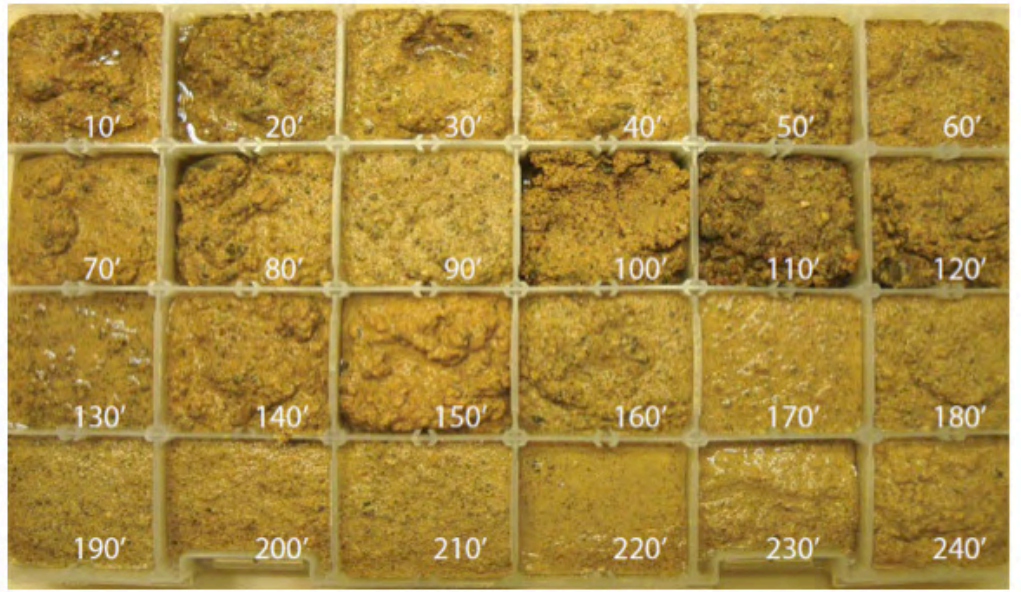

B

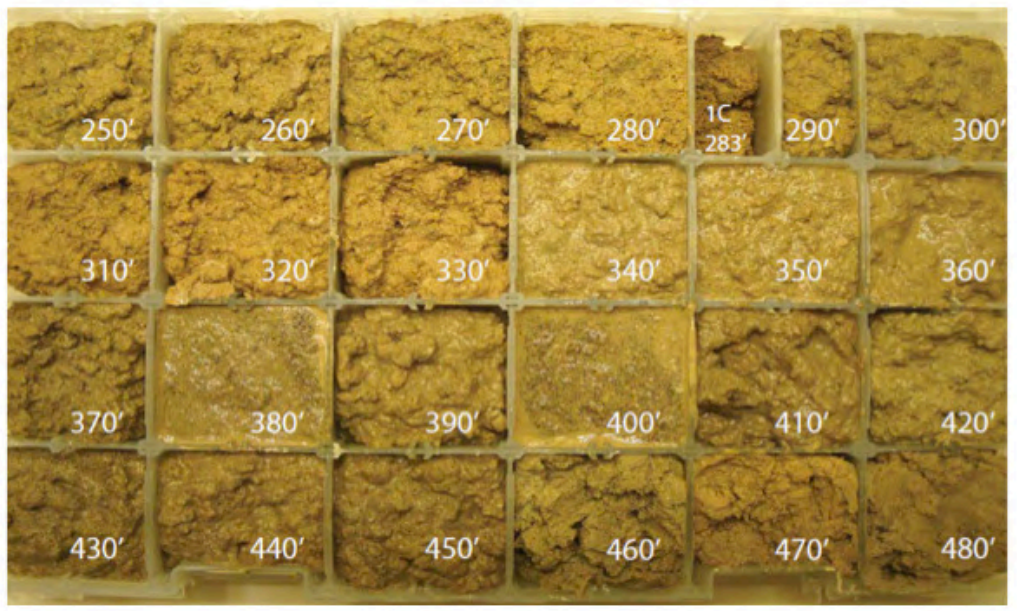

$\mathrm{C}$

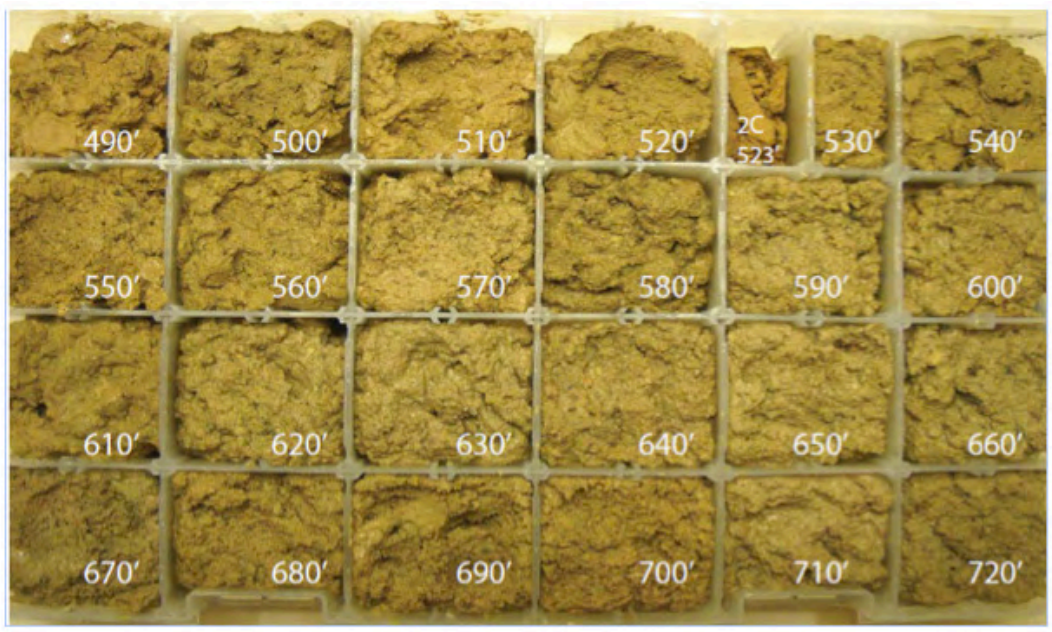

$\mathrm{D}$

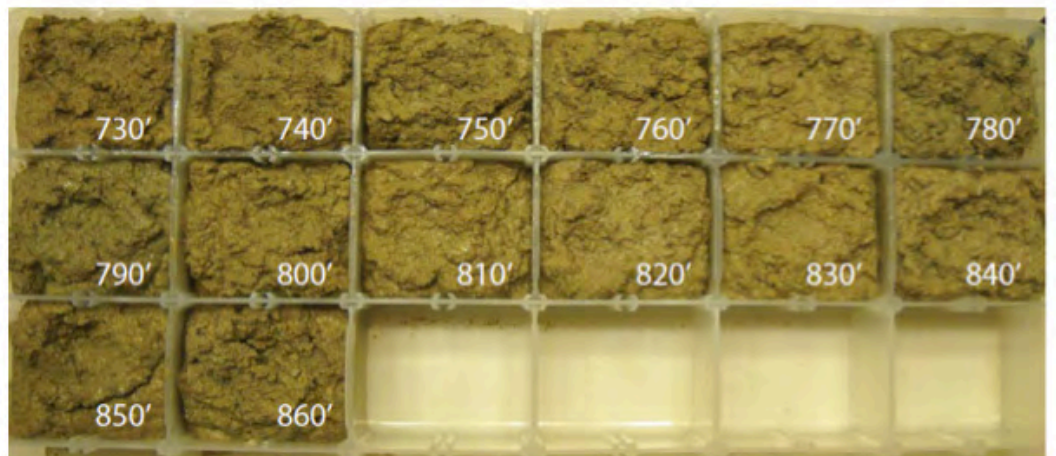

Figure 33. Photographs of cuttings from the shaker table for borehole NELT7 at Fort Irwin, California. A, samples from 10 to 240 feet (ft); $B$, samples from 250 to $480 \mathrm{ft} ; C$, samples from 490 to $720 \mathrm{ft} ; D$, samples from 730 to $860 \mathrm{ft}$. Core samples at 283, 523, and $865 \mathrm{ft}$. Images are not color corrected. A square chip cell is 50×55 millimeters. U.S. Geological Survey photographs by Joseph Nawikas. 


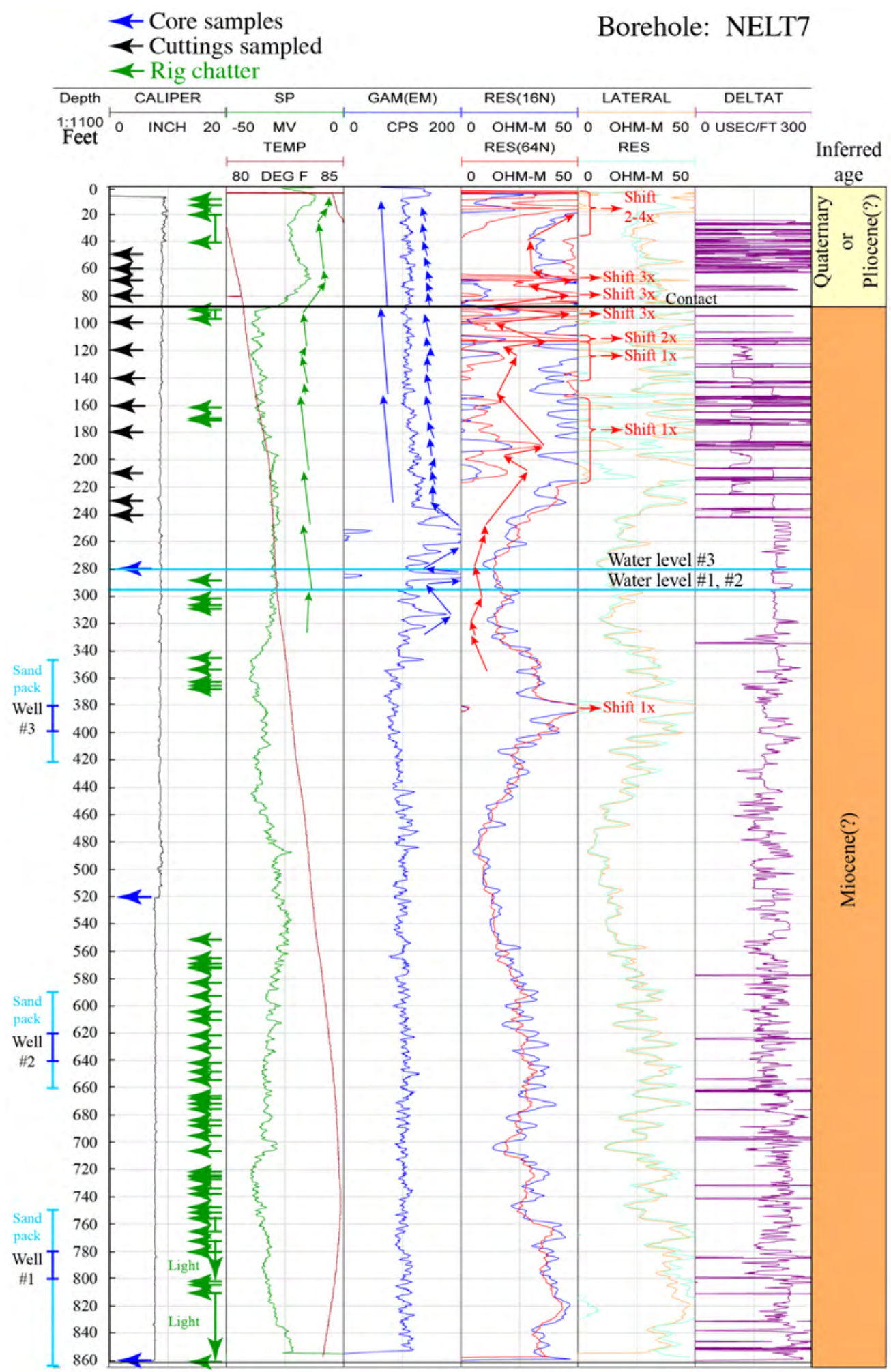

Figure 34. Graph showing locations of cuttings samples in borehole NELT7 at Fort Irwin, California, used for detailed examination compared to core, borehole geophysical logs, rig chatter, and locations of wells 1 , 2 , and 3 . 
From 180 to $240 \mathrm{ft}$, there are small amounts (2-3 percent) of tuffaceous fragments. At $180 \mathrm{ft}$, there are a number of fragments of pumice clasts, and nonwelded to partially welded tuff (ignimbrite). From 210 to $230 \mathrm{ft}$, there are fragments of slightly (clay?) altered, fine- to mediumgrained, pumiceous lithic-crystal and crystal-lithic tuff. At $240 \mathrm{ft}$, there are fragments of slightly (clay?) altered, fine-grained, lithic-bearing tuff.

From 180 to $240 \mathrm{ft}$, there is a continuation of the decrease in coatings on lithic clasts (which began at sample $160 \mathrm{ft}$ ); however, there are several details in this decrease. Samples from 180 and $210 \mathrm{ft}$ are similar, but with the coatings in the sample at $210 \mathrm{ft}$, there is a slight decrease in the amount of lithic-rich matrix and the absence of pumice-lithic-rich matrix. At $230 \mathrm{ft}$, there is a decrease in the total amount of coatings, and lithic-rich matrix is absent. However, at $240 \mathrm{ft}$, the total amount of coatings increases back to approximately 10 percent, and there is a small amount of lithic-rich matrix.

The cores collected at 280, 520, and $860 \mathrm{ft}$ had recovery of 94, 77, and 13 percent, respectively. Both samples at 280 and $520 \mathrm{ft}$ are polymictic, fine- to medium-grained sandstone with very fine-grained matrix, and plutonic clasts are more abundant than volcanic clasts. The core at $860 \mathrm{ft}$ is polymictic, pebbly sandstone to conglomerate with rounded to subangular clasts in a lithic-rich matrix, and plutonic clasts are more abundant than volcanic clasts. Both core samples were collected where there was no rig chatter, and core from $860 \mathrm{ft}$ was in a part of the borehole where there was a lot of rig chatter (fig. 34).

Based on a variety of lithologic features from 86 to $240 \mathrm{ft}$, there are possibly 20-80-ft thick cyclic variations within the lithologic section that are composed of clasts from different provenances (granitic and volcanic) that variably mix to form similar types of sedimentary rocks. These sequences vary from slightly coarser and finer grained sandstone to conglomerate, with variations in the amounts of fine-grained and (or) tuffaceous material included as matrix.

From 80 to $280 \mathrm{ft}$, there are several variations in the gamma, resistivity, and spontaneous potential geophysical logs. Most notably there are changes in values (or in the characteristics in the values) at about 86, 151, 197, 207, 230, and $254 \mathrm{ft}$; however, some of the largest changes in the gamma and resistivity data occur from 207 to $254 \mathrm{ft}$. From 86 to $207 \mathrm{ft}$, there are large values and large variations of resistivity. At $207 \mathrm{ft}$, there is the stratigraphically deepest peak in large resistivity values. From 207 to $278 \mathrm{ft}$, there are large down-hole decreases in values with progressive decreases in both amplitude and mean values. At 230 and $262 \mathrm{ft}$, there are small peaks along the down-hole decreasing trends of resistivity values. At $230 \mathrm{ft}$, there is the beginning of a sharp down-hole increase of gamma, and at $247 \mathrm{ft}$ there is a small trough in the increasing gamma values. Gamma values peak at $254 \mathrm{ft}$ and begin a down-hole decrease in mean values and associated decrease in amplitude to a depth of $355 \mathrm{ft}$. From 86 to $207 \mathrm{ft}$, there are numerous small cycles (with 6-18 ft wavelengths and small amplitudes) that occur within longer complex cycles that are up to $60 \mathrm{ft}$ in wavelength and have down-hole increases in mean values. From 207 to $327 \mathrm{ft}$, the spontaneous potential also has numerous cycles; however, there is only a very small increase in the mean values. These variations in geophysical log data probably represent variations in the lithostratigraphy; however, detailed correlations are beyond the scope of this study. 
Probably Quaternary to Pliocene(?)

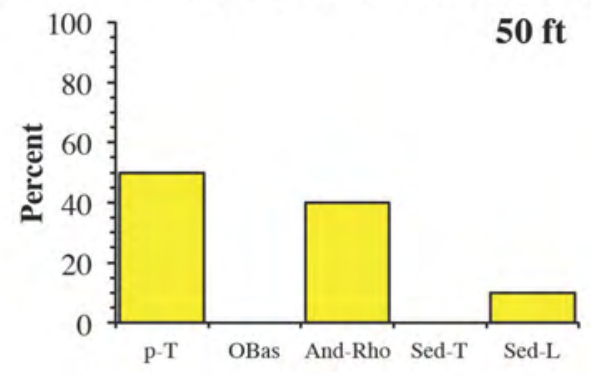

Sed- $\mathrm{L}$ is medium-grained sandstone with fine-grained, tuffaceous (pumice-rich) matrix.

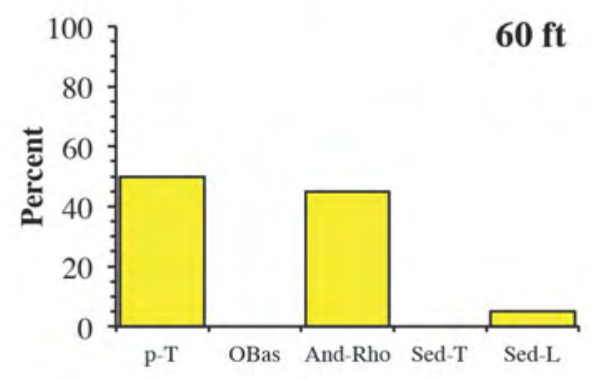

Sed-L is medium-grained sandstone with fine-grained, tuffaceous (pumice-rich) matrix.

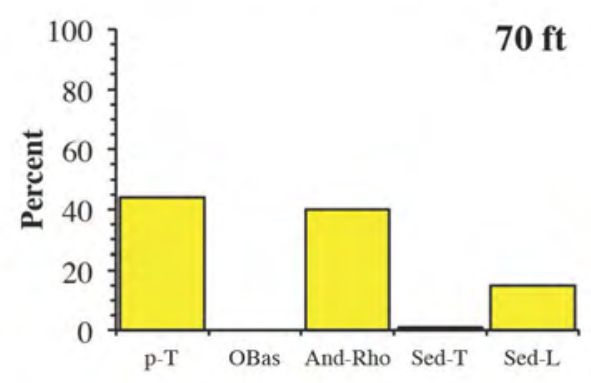

Sed-T is nonwelded, crystal-lithic, pumiceous tuff Sed-L is medium-grained sandstone with fine-grained, tuffaceous (pumice-rich) matrix.
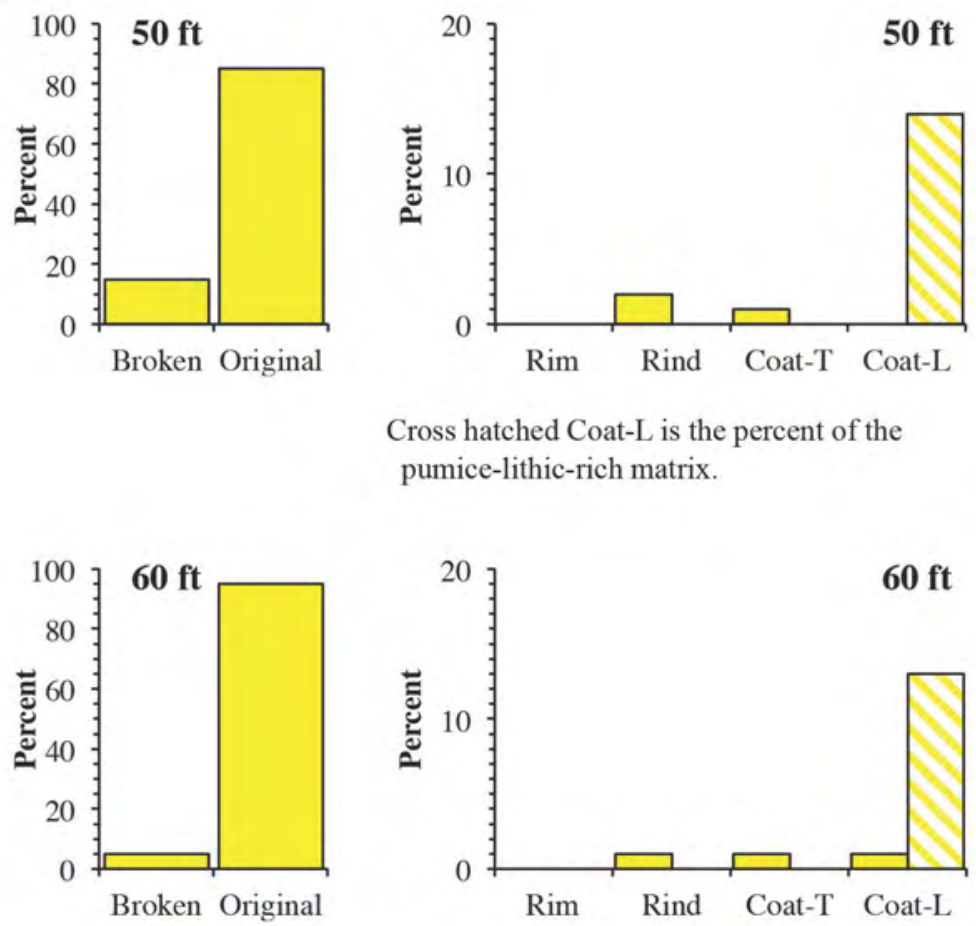

Cross hatched Coat- $\mathrm{L}$ is the percent of the pumice-lithic-rich matrix.
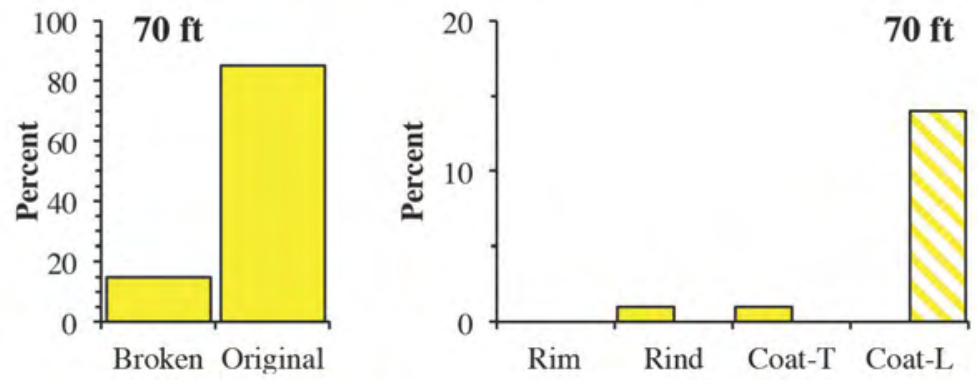

Cross hatched Coat- $\mathrm{L}$ is the percent of the pumice-lithic-rich matrix.

Figure 35. Bar graphs of components of cuttings samples in borehole NELT7 at Fort Irwin, California. Lithostratigraphic units: yellow, lithic-rich sediment, probably Quaternary or Pliocene(?); orange, tuffaceous sediment, probably Miocene(?). Components: p-T, pre-Tertiary; Obas, porphyritic olivine basalt; And-Rho, andesite to rhyolite; Sed-T, tuffaceous sedimentary rocks, Sed-L, lithic-rich sedimentary rocks; Broken, broken surfaces; Original, original surfaces; Rim, thin layer of crystallization in volcanic rock along a cooling fracture; Rind, calcite, opal, or chalcedony deposits on a lithic clast; Coat-T, tuffaceous coatings; Coat-L, lithic-rich coatings. 


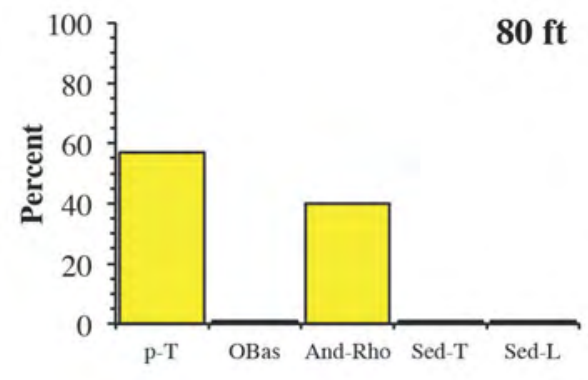

OBas, Sed-T, and Sed-L are $<1 \%$.

OBas is andesitic basalt or basaltic andesite

Sed-T is pumiceous tuff with clay(?)-altered matrix

Sed-L is medium-grained sandstone with

fine-grained, tuffaceous (pumice-rich)

matrix.

\section{Probably Miocene(?)}

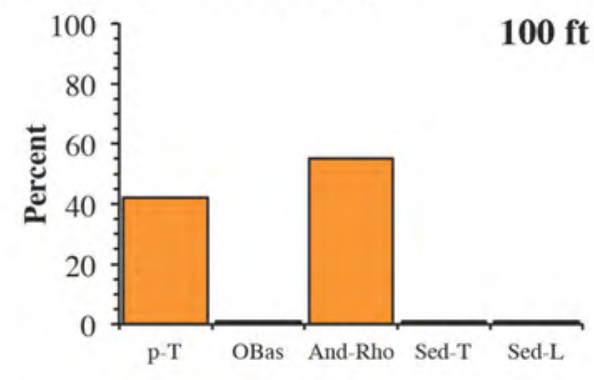

OBas, Sed-T, and Sed-L probably are $<1 \%$.

OBas some fragments hav $5 \%$ small olivine

phenocrysts, other fragments are not porphyritic.

Sed-T is partially welded ignimbrite (clast from Miocene)

Sed-L is medium- to coarse-grained

sandstone cemented by calcite

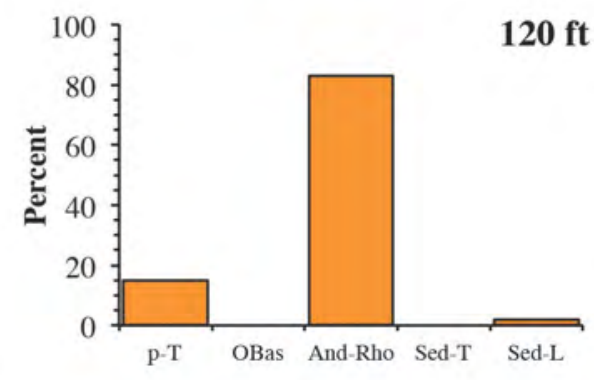

Sed- $\mathrm{L}$ is medium-grained sandstone with crystal, lithic, and pumice grains, and lithic-rich sandstone cemented by calcite.

\section{Figure 35.-Continued}
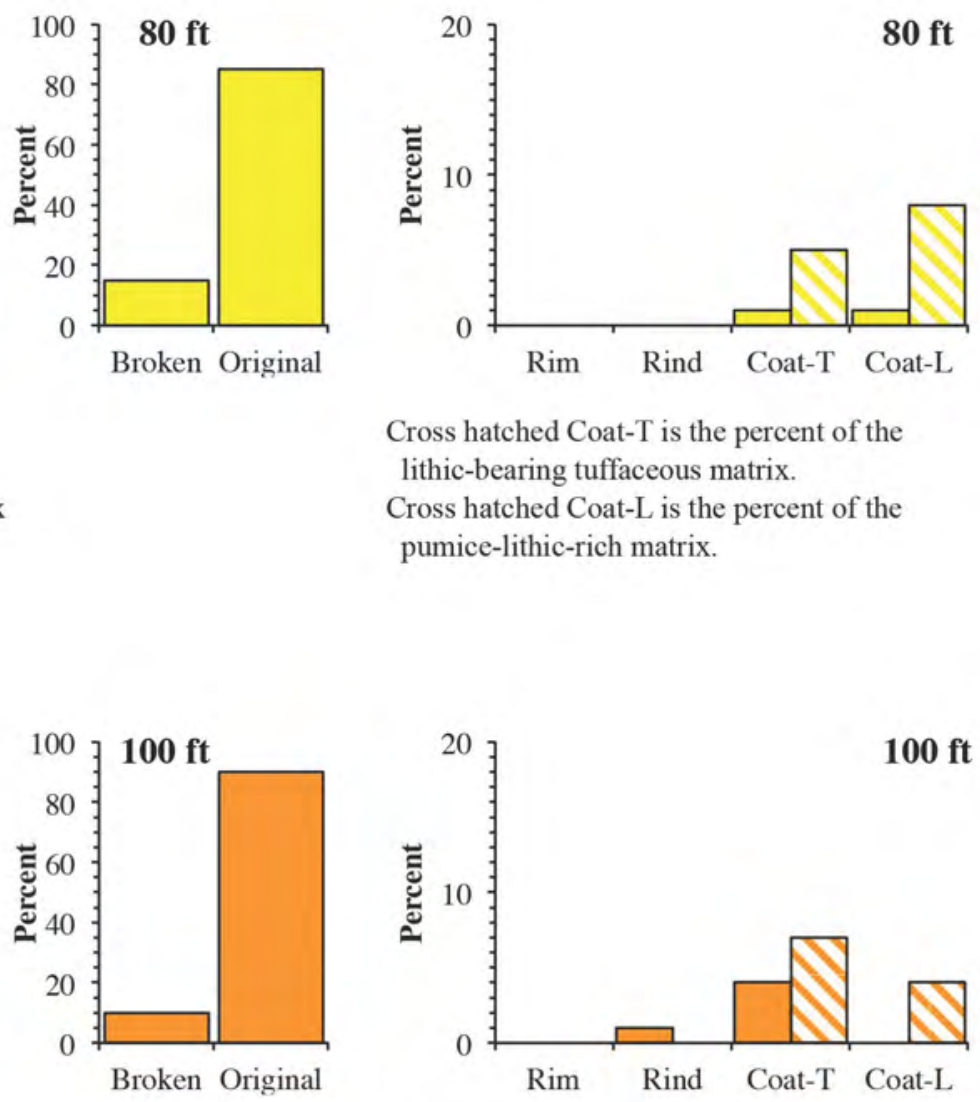

Cross hatched Coat-T is the percent of the lithic-bearing tuffaceous matrix.

Cross hatched Coat- $\mathrm{L}$ is the percent of the pumice-lithic-rich matrix.

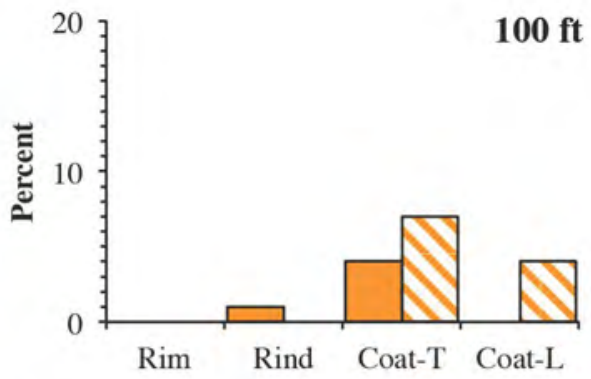

Cross hatched Coat-T is the percent of the crystal-bearing tuffaceous matrix.

Cross hatched Coat- $\mathrm{L}$ is the percent of the pumice-lithic-rich matrix.

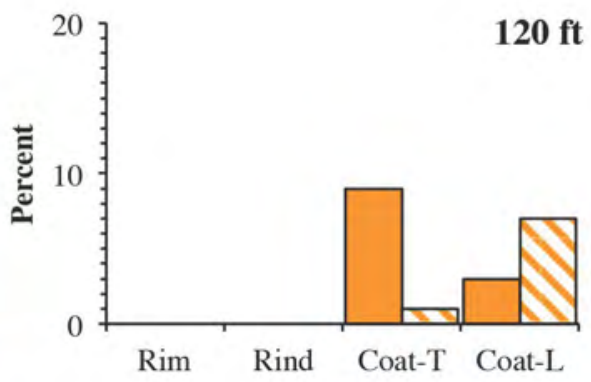

Cross hatched Coat-T is the percent of the lithic-bearing tuffaceous matrix.

Cross hatched Coat- $\mathrm{L}$ is the percent of the pumice-lithic matrix (transitional to pumiceous tuffaceous sandstone matrix). 


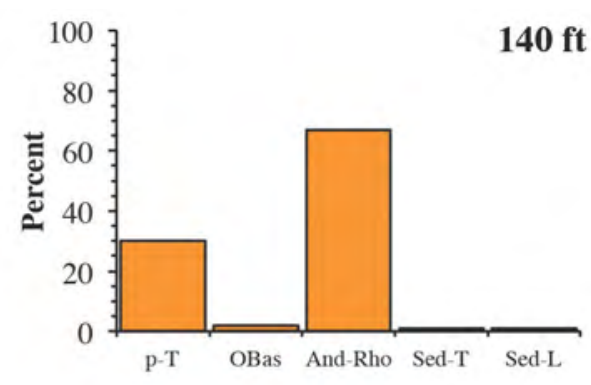

OBas is andesitic basalt or basaltic andesite Sed-T and Sed-L are $<1 \%$.

Sed-T is a very fine-grained, white, altered tuff Sed-L is lithic-crystal-bearing, pumice-rich sandstone

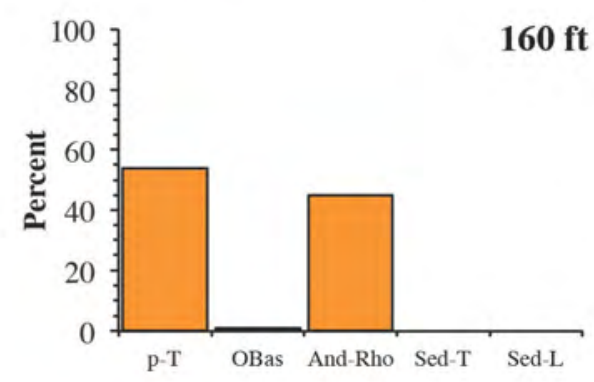

OBas is $<1 \%$.

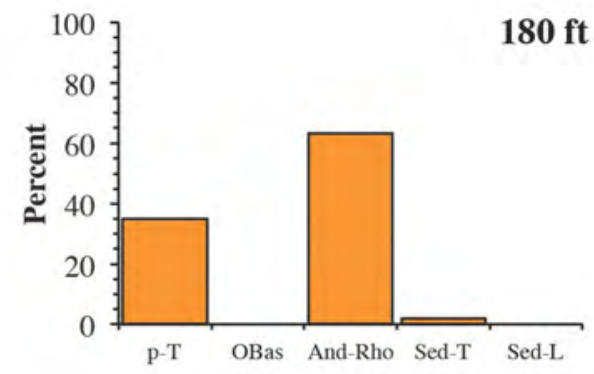

Sed-T includes fragments of pumice, and nonwelded to partially welded tuff (ignimbrite)

Figure 35.-Continued
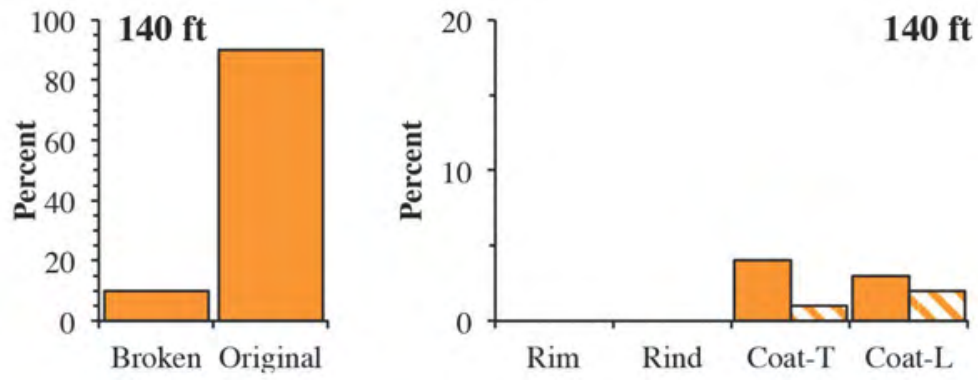

Cross hatched Coat- $T$ is the percent of the lithic-bearing tuffaceous matrix.

Cross hatched Coat- $\mathrm{L}$ is the percent of the pumice-lithic-rich matrix.
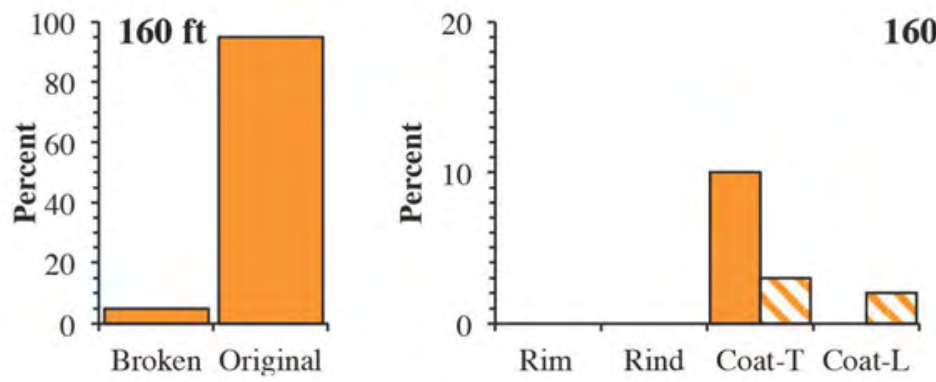

Cross hatched Coat-T is the percent of the lithic-bearing tuffaceous matrix.

Cross hatched Coat- $\mathrm{L}$ is the percent of the pumice-lithic-rich matrix.
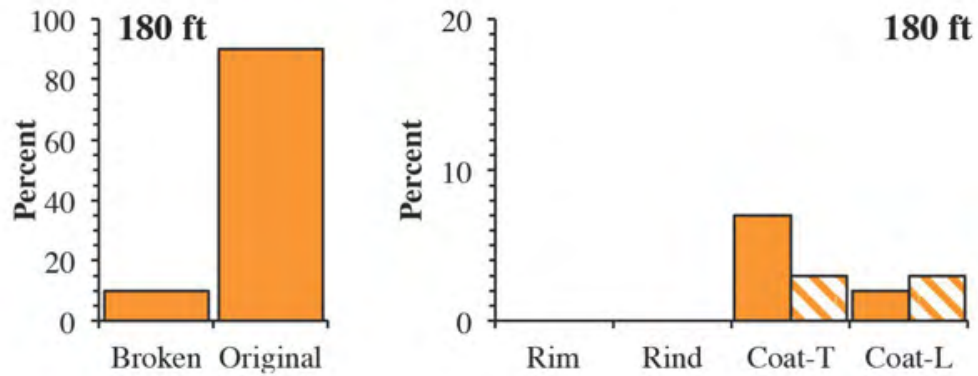

Cross hatched Coat-T is the percent of the lithic-bearing tuffaceous matrix.

Cross hatched Coat- $\mathrm{L}$ is the percent of the pumice-lithic-rich matrix. 


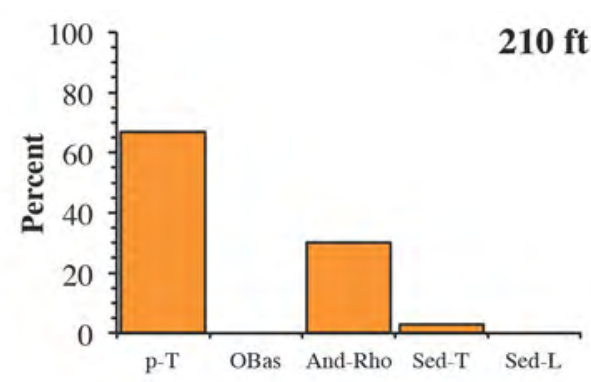

Sed-T is fine- to medium-grained, pumiceous lithic-crystal tuff with very fine-grained altered matrix.

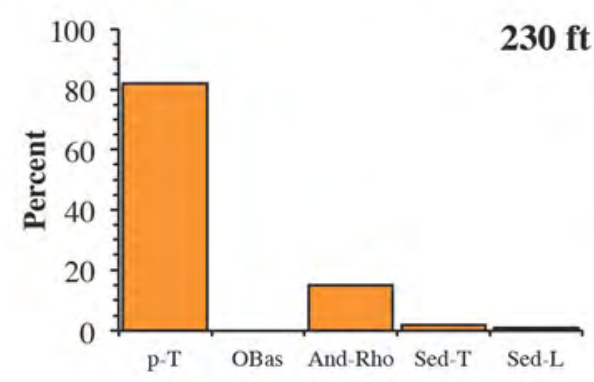

Sed-T is a partially altered pumice fragment and fine- to medium-grained, pumiceous, crystal-lithic tuff.

Sed-L isl a lithic-rich medium-grained sandstone.

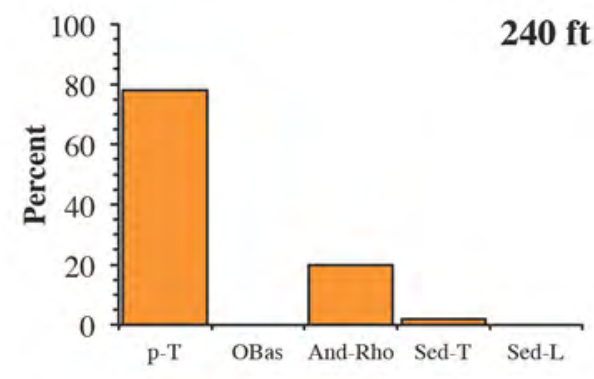

Sed-T is a fine-grained, lithic-bearing, white, tuff with (altered?) matrix.
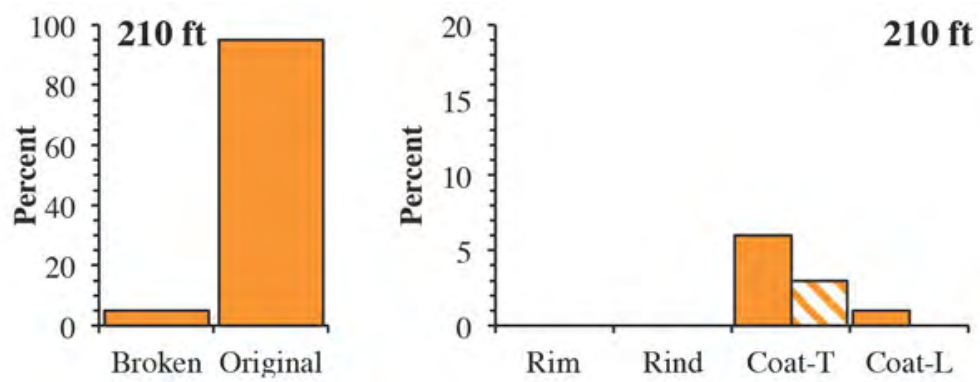

Cross hatched Coat-T is the percent of the lithic-bearing tuffaceous matrix.
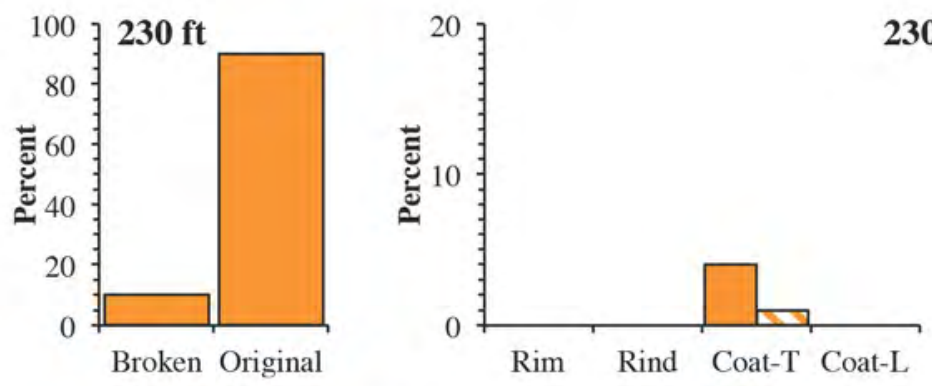

Cross hatched Coat-T is the percent of the lithic-bearing tuffaceous matrix.

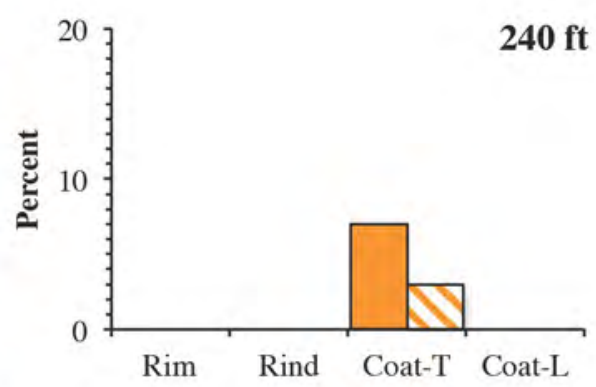

Cross hatched Coat-T is the percent of the lithic-bearing tuffaceous matrix.

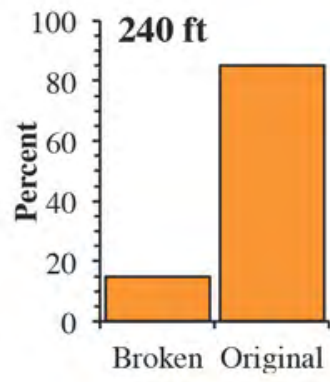

Figure 35.-Continued

In the TEM data from NLI0 and NL18, there is a small to moderate decrease in minimum-layer model resistivity at 178 and $210 \mathrm{ft}$, respectively (Burgess and Bedrosian, 2014). The fixed-thickness, 20-layer model resistivity values from both NL18 and NLI0 are slightly more varied in values. In NL18, there is a peak at $150 \mathrm{ft}$, a trough from 238 to $312 \mathrm{ft}$, and a slight peak from 412 to $544 \mathrm{ft}$. The TEM peak at $150 \mathrm{ft}$ is a little shallower than the associated local peak borehole values, TEM trough approximates the low borehole values, and the TEM peak from 412 to $544 \mathrm{ft}$ is a little deeper than the borehole peak from 327 to $447 \mathrm{ft}$. In NLl0, there is a peak at about $150 \mathrm{ft}$, a trough at about $272 \mathrm{ft}$, and a peak at about $365 \mathrm{ft}$. The TEM peak at about $150 \mathrm{ft}$ is a little shallower than the associated local peak borehole values, the TEM trough 
approximates the low borehole values at this depth, and the TEM peak at about $365 \mathrm{ft}$ approximates the peak borehole values at about $382 \mathrm{ft}$.

The static water level (water table) is at $280 \mathrm{ft}$ in well \#3 and $294 \mathrm{ft}$ in wells \#1 and \#2 (Kjos and others, 2014; fig. 34), and it might have some effects on geophysical log values; however, they are not what might be anticipated from entering the saturated zone. For example, there is a small down-hole decrease in spontaneous potential at $294 \mathrm{ft}$, and there are slight increases in resistivity at both 280 and $294 \mathrm{ft}$. In other boreholes at Fort Irwin, the influence of the water table on geophysical log values has not been demonstrated.

No samples were examined from $250 \mathrm{ft}$ to the bottom of the borehole at $865 \mathrm{ft}$; however, the rig lithologic log indicates an increase in the amount of rig chatter and a "formation change" at $555 \mathrm{ft}$ (Joseph Nawikas, USGS, written commun., 2012; fig. 34), and this depth does correlate to the down-hole increase in resistivity, and slight changes in gamma and spontaneous potential. From 240 to $345 \mathrm{ft}$, there is an overall increase in gamma values with medium to large, 2-15 ftthick peak values, and these might be attributed to an increase in tuffaceous material, or specific tephra beds, but this has not been confirmed. From 250 to $865 \mathrm{ft}$, the geophysical log data suggest five large (70-120 ft thick) cycles that are defined where two or three geophysical log values (gamma, resistivity, and spontaneous potential) have sharp changes in values or characteristics in the values. Each of these cycles has possible subcycles, or at least identifiable changes in values or characteristics that probably indicate a slight change in the trends of the rock properties. Although specific lithostratigraphic features have not been correlated to these geophysical log cycles, these cycles probably represent variations in the lithostratigraphic sequence.

\section{Summary of Lithostratigraphic Features and Units in Borehole NELT7}

In borehole NELT7, from 0 to $280 \mathrm{ft}$, there are numerous lithostratigraphic cycles that vary from 10-80 ft thick, and these cycles are consistent with (or nested within) cycles of geophysical log values that vary from 4-70 ft thick. There are no well-defined lithologic or geophysical data that uniquely define the top of the Miocene(?) section in this borehole. Based only on lithostratigraphic data, the contact between rocks deposited during the inferred Quaternary to Pliocene(?) and those deposited during the inferred Miocene(?) is likely located between 70 and $80 \mathrm{ft}$; however, by comparing the lithostratigraphic data with geophysical log values, the contact is most likely at $86 \mathrm{ft}$ (table 3). Most cuttings fragments from sample depths of 70 and $80 \mathrm{ft}$ are pre-Tertiary granitic and volcanic lithic clasts (44-57 percent and 40 percent, respectively), but the changes in the smaller amounts of rock types and in the coatings on lithic clasts support the contact between 70 and $80 \mathrm{ft}$. In the samples from 50 to $70 \mathrm{ft}$, (1) mediumgrained sandstone with fine-grained tuffaceous pumice (pumice-rich) matrix form 5-15 percent of fragments, and (2) the coatings are 1 percent tuffaceous coatings and 14 percent pumice-rich, lithic-rich coatings. In contrast, the samples from 80 and $100 \mathrm{ft}$ have (1) 1 percent basalt, 1 percent tuffaceous or pumice clasts, and 1 percent medium- to coarse-grained lithic-rich sandstone, and (2) the coatings are 6 and 11 percent tuffaceous coatings and 9 and 4 percent mostly pumice-lithic-rich coatings (respectively). At $86 \mathrm{ft}$, there are changes in gamma, resistivity, and spontaneous potential that support the changes in lithostratigraphic features at this depth. The reconciliation of lithostratigraphic and geophysical log value contacts is that the sample at $80 \mathrm{ft}$ is just $6 \mathrm{ft}$ above the contact, is transitional in lithostratigraphic components, and probably contains clastic material derived from the more tuffaceous rocks below the contact. At depths from 210 to $280 \mathrm{ft}$, there are numerous changes in geophysical log values; however, there 
are no large and distinctive changes in lithostratigraphic features, and those that do occur are consistent with facies change in the alluvial fan materials deposited during the Miocene(?). Similar trends in lithostratigraphic and geophysical log cycles continue to the bottom of the borehole at $865 \mathrm{ft}$, and along with the core from $860 \mathrm{ft}$, the lower part of the section appears to be polymictic, pebbly sandstone to conglomerate that is also consistent with facies change in the alluvial fan materials deposited during the Miocene(?).

\section{Summary}

Eight boreholes, including GOLD1 in the Goldstone Lake basin and the series from NELT1 to NELT7 in Nelson Lake basin, were drilled using mud-rotary techniques in 2011 and 2012 as part of a groundwater evaluation of the Fort Irwin National Training Center. Coring in the boreholes was very limited, and typically included three core runs from 3 to $5 \mathrm{ft}$ long; however, where core was recovered, it provided a stratigraphic context for cuttings descriptions. Sample preparation of cuttings included gentle washing and wet sieving in an attempt to preserve fragments of the matrix material in the sedimentary rock that might otherwise be degraded by more aggressive treatment. Separation of drilling mud and cuttings is best done before the drilling mud begins to dry and becomes attached to the cuttings, at which time it is harder to distinguish drilling mud from coatings of matrix on the clasts. Cuttings were examined with hand lens and binocular microscope, and visual estimates of abundance for a variety of features were made on bulk samples with supporting observations of individual grains. Both wet sieving and visual estimates of features are simple enough to be done at the rig in support of lithologic logging.

The standard practices at Fort Irwin of lithologic descriptions and logging (mostly grain size distribution in cuttings with occasional identification of specific rock types) and collection and evaluation of geophysical logs (mostly to determine the type and construction of wells) provide consistent data for the boreholes; however, this study used different descriptive and integrated lithological-geophysical stratigraphic analysis to describe the rocks that were penetrated in the boreholes. In this report, supplemental lithologic data were described to determine what types of rocks were drilled, and then compared to detailed characteristics in geophysical log values to determine approximate thicknesses and, in some cases, contacts in stratigraphic sequences. Some of the detailed lithostratigraphic components include (1) identification of specific types of rock fragments in the cuttings or core (including types of sedimentary rocks), (2) the amounts of original surfaces versus broken during drilling surfaces on fragments and clasts to estimate possible grain sizes, and (3) identification of coatings on clasts that indicate the type of matrix in the host rock.

Boreholes GOLD1 and the NELT-series are in different geomorphic basins, and the rocks penetrated were in different areas within the eastern edge of the Miocene Eagle Crags volcanic field. In borehole GOLD1, typically enough fragments of the drilled host rock (especially the matrix) were collected to determine the types of rock present. Rock types included basaltic lava flows, monomictic breccia, nonwelded to partially welded ignimbrites, and tuffaceous and lithicrich sedimentary rocks. Coatings on lithic clasts showed very good correlations with the textures of the host rock matrix, thereby supporting the technique of inferring the matrix of the host rock from coatings. The NELT-series boreholes penetrated various types of sedimentary rocks, from lithic-rich sandstone and conglomerate to very fine-grained sandstone or siltstone composed mostly of crystallized volcanic clasts. These materials were deposited in alluvial fan, fluvial, lacustrine, and groundwater discharge environments. Deposits also included minor amounts of 
possible fallout tephra and nonwelded ignimbrites, and NELT7 had both volcanic and preTertiary bedrock clasts. Use of coatings on lithic clasts was important in the evaluation of cuttings from these deposits because in most NELT-series boreholes, very few fragments of the host rock matrix were sampled. This lack of the host rock matrix fragments apparently results from the mechanical disaggregation of poorly lithified host rock matrix during drilling.

Some lithostratigraphic features or sequences are correlated to geophysical log data (especially gamma, resistivity, and spontaneous potential values) or the characteristics or trends of data. The geophysical log values represent lithostratigraphic and (or) hydrogeologic properties, so geophysical logs provide insights into the stratigraphy of properties at a variety of length scales. For example, basalt is penetrated near the bottom of GOLD1, and the gamma values from basalt are much smaller than in the overlying tuffaceous deposits. Basalts were also penetrated in other boreholes in the Fort Irwin area (for example, CRTH1, CRTH2, SBTW, and SBMC; Kjos and others, 2014). Thin sharp increases in gamma values in several boreholes (NELT1, NELT4, NELT7, and BLA5) are suspected to result from silicic fallout tephra beds. Numerous 15-80-ft-thick gamma and resistivity cycles occur in many of the boreholes, and many of these cycles probably result from variations in the lithostratigraphic sequences.

Estimates of approximate ages for lithostratigraphic sequences have been made based on the abundance of tuffaceous material in the sedimentary matrix that was probably derived from the nearby 21-12 Ma Eagle Crags volcanic field. In the Fort Irwin area, the Cenozoic sedimentary rocks can be divided into (1) a pre-volcanic epiclastic sequence derived from locally exposed plutonic and metamorphic rocks with the possibility of a few tephra beds derived from distant sources, (2) a synvolcanic sequence formed as primary volcanic rocks (lava flows, ignimbrites, and fallout tephra beds) and sedimentary rocks derived from the primary volcanic deposits along with locally derived pre-Tertiary bedrock, and (3) a postvolcanic epiclastic sequence derived from erosion of exposed volcanic rocks and locally from the pre-Tertiary bedrock with the possibility of a few tephra beds derived from distant sources. After the end of volcanic activity in the Eagle Crags volcanic field at about $12 \mathrm{Ma}$, ash was not being renewed to the landscape, and it was progressively being eroded from the hillsides; therefore, deposits during the middle to upper Miocene were slowly transforming in composition and types of surficial processes that gave rise to the more detrital depositional features. The lithostratigraphic feature-based estimates of age indicate the Quaternary or Pliocene(?) rocks typically are only 70-130 ft thick; however, in some boreholes, the contact between these sequences was not easy to determine and alternative depths to the contacts are provided (table 3). One of the main implications of these lithostratigraphic feature-based estimates of age is that several waterbearing horizons are in the Miocene(?) section.

\section{Acknowledgments}

Understanding of the lithostratigraphic, geophysical, and hydrogeologic properties and structural relations in the area was enhanced by discussions with David M. Miller, Paul Bedrosian, Jill Densmore-Judy, and Matt Burgess. Discussions with the USGS rig-site geologists Adam Kjos, Joseph Nawikus, and Anthony Brown were extremely helpful in understanding drilling and logging procedures and for sharing their experiences and perspectives of the lithostratigraphy and geophysical logs. Thanks to Jose Rosario for helping with sample preparation in the laboratory, and Mark Mercer for preparation of thin sections. Reviews by Geoff Phelps and Richard Stanley improved the manuscript and are greatly appreciated. 


\section{References Cited}

Barton, N., and Choubey, V., 1977, The shear strength of rock joints in theory and practice:

Rock Mechanics, v. 10, no. 1-2, p. 1-54.

Buesch, D.C., 2005, Role of the vapor phase in the welding, crystallization, and cooling of ignimbrites at Yucca Mountain, Nevada, and Kingman, Arizona [abs.]: Geological Society of America Abstracts with Programs, v. 37, no. 7, p. A530.

Buesch, D.C., 2014, Introduction to the Geologic and Geophysical Studies of Fort Irwin, California, chap. A of Buesch, D.C., ed., Geology and geophysics applied to groundwater hydrology at Fort Irwin, California: U.S. Geological Survey Open-File Report 2013-1024-A, 8 p., https://doi.org/10.3133/ofr20131024A.

Buesch, D.C., Beason, S.C., and Spengler, R.W., 1999, Relations among welding, vapor-phase activity, crystallization, and fractures in the Tiva Canyon and Topopah Spring Tuffs at Yucca Mountain, Nevada [abs.]: Geological Society of America Abstracts with Programs, v. 31, no. 7, p. A476-A477.

Buesch, D.C., Miller, D.M., and Menges, C.M., 2018, Cenozoic geology of Fort Irwin and vicinity, California, chap. C of Buesch, D.C., ed., Geology and geophysics applied to groundwater hydrology at Fort Irwin, California: U.S. Geological Survey Open-File Report 2013-1024-C, 38 p., https://doi.org/10.3133/ofr20131024C.

Buesch, D.C., Spengler, R.W., Moyer, T.C., and Geslin, J.K., 1996, Proposed stratigraphic nomenclature and macroscopic identification of lithostratigraphic units of the Paintbrush Group exposed at Yucca Mountain, Nevada: U.S. Geological Survey Open-File Report 94469, 47 p., https://pubs.er.usgs.gov/publication/ofr94469.

Burgess, M.K., and Bedrosian, P.A., 2014, Time-domain electromagnetic surveys at Fort Irwin, San Bernardino County, California, 2010-12, chap. F of Buesch, D.C., ed., Geology and geophysics applied to groundwater hydrology at Fort Irwin, California: U.S. Geological Survey Open-File Report 2013-1024-F, 64 p., https://doi.org/10.3133/ofr20131024F.

Fisher, R.V, and Schmincke, H.-U., 1984, Pyroclastic rocks: Berlin, Springer-Verlag, 472 p. Flint, A.L., Flint, L.E., Kwicklis, E.M., Bodvarsson, G.S., and Fabryka-Martin, J.M., 2001, Hydrology of Yucca Mountain, Nevada: Reviews of Geophysics, v. 39, no. 4, p. 447-470, https://doi.org/10.1029/1999RG000075.

Flint, A.L., Flint, L.E., Kwicklis, E.M., Fabryka-Martin, J.T., and Bodvarsson, G.S., 2002, Estimating recharge at Yucca Mountain, Nevada, USA - Comparison of methods: Hydrogeology Journal, v. 10, no. 1, p. 180-204, https://doi.org/10.1007/s10040-001-0169-1.

Flint, L.E., Buesch, D.C., and Flint, A.L., 2006, Characterization of unsaturated zone hydrogeologic units using matrix properties and depositional history in a complex volcanic environment: Vadose Zone Journal, v. 5, no. 1, p. 480-492.

Folk, R.L., 1954, The distinction between grain size and mineral composition in sedimentaryrock nomenclature: The Journal of Geology, v. 62, no. 4, p. 344-359.

Folk, R.L, 1974, Petrology of sedimentary rocks: Austin, Texas, Hemphill Publishing Co., 184 p. GretagMacbeth, 2000, Munsell Soil Color Charts: New Windsor, New York, GretagMacbeth.

Keys, W.S., and MacCary, L.M., 1971, Application of borehole geophysics to water-resources investigation: U.S. Geological Survey Techniques of Water-Resources Investigations, book 2, chap. E1, 126 p.

Keys, W.S., 1990, Borehole geophysics applied to ground-water investigations: U.S. Geological Survey Techniques of Water-Resources Investigations, book 2, chap. E2, 150 p. 
Kjos, A.R., Densmore, J.N., Nawikas, J.M., and Brown, A.A., 2014, Construction, water-level, and water-quality data for multiple-well monitoring sites and test wells, Fort Irwin National Training Center, San Bernardino County, California, 2009-12, U.S. Geological Survey Data Series 788, 139 p., https://doi.org/10.3133/ds788.

Krumbein, W.C., 1941, Measurement and geological significance of shape and roundness of sedimentary particles: Journal of Sedimentary Research, v. 11, no. 2, p. 64-72, 1 pl.

Miller, D.M., Menges, C.M., and Lidke, D.J., 2014, Generalized surficial geologic map of the Fort Irwin area, San Bernardino County, California, chap. B of Buesch, D.C., ed., Geology and geophysics applied to groundwater hydrology at Fort Irwin, California: U.S. Geological Survey Open-File Report 2013-1024-B, 11 p., scale 1:100,000, https://doi.org/10.3133/ofr20131024B.

Miller, D.M., and Yount, J.L., 2002, Late Cenozoic tectonic evolution of the north-central Mojave Desert inferred from fault history and physiographic evolution of the Fort Irwin area, California, in Glazner, A.F., Walker, J.D., and Bartley, J.M., eds., Geologic evolution of the Mojave Desert and southwestern basin and range: Geological Society of America Memoir 195, p. 173-197.

Neymark, L.A., Paces, J.B., Wooden, J.L, and Buesch, D.C., 2007, U-Pb Dating of opal in deeply buried soils, Yucca Mountain, Nevada, using secondary ion mass spectrometry [abs.]: Geological Society of America, Abstracts with Programs, v. 39, no. 6, p. 604.

Sabin, A. E., 1994, Geology of the Eagle Crags volcanic field, northern Mojave Desert, China Lake Naval Air Weapons Station, California: Golden, Colo., Colorado School of Mines, Department of Geology and Geological Engineering, Ph.D. dissertation, 190 p.

Sabin, A.E., Monastero, F.C., and Katzenstein, A.M., 1994, Middle to late Miocene age stratovolcano on the South Ranges, Naval Air Weapons Station, San Bernardino County, California, in McGill, S.F., and Ross, T.M., eds., Geological Investigations of an active margin: San Bernardino, Calif., San Bernardino County Museum Association, p. 293-301.

Schermer, E.R., Luyendyk, B.P., and Cisowski, S., 1996, Late Cenozoic structure and tectonics of the northern Mojave Desert: Tectonics, v. 15, no. 5, p. 905-932.

Walker, J.D., Berry, A.K., Davis, P.J., Andrew, J.E., Mitsdarfer, J.M., and Glazner, A.F., 2002a, Geologic map of northern Mojave Desert and southwestern basin and range, CaliforniaCompilation method and references, in Glazner, A.F., Walker, J.D., and Bartley, J.M., eds., Geologic evolution of the Mojave Desert and southwestern basin and range: Boulder, Colo., Geological Society of America Memoir 195, p. 295-296.

Walker, J.D., Black, R.A., Berry, A.K., Davis, P.J., Andrew, J.E., and Mitsdarfer, J.M., 2002b, Geologic maps of the northern Mojave Desert and southwestern basin and range province, California-Explanation of maps on CD-ROM, in Glazner, A.F., Walker, J.D., and Bartley, J.M., eds., Geologic Evolution of the Mojave Desert and southwestern basin and range: Boulder, Colo., Geological Society of America Memoir 195, p. 297-299.

Yount, J.C., Schermer, E.R., Felger, T.J., Miller, D.M., and Stephens, K.A., 1994, Preliminary geologic map of Fort Irwin Basin, north-central Mojave Desert, California: U.S. Geological Survey Open-File Report 94-173, pamphlet 27 p., 1 sheet, scale 1:24,000, https://pubs.er.usgs.gov/publication/ofr94173. 


\section{Appendix 1. Standard Sample Collection and Geophysical Data}

The U.S. Geological Survey California Water Science Center (CaWSC) manages the drilling of boreholes, the construction of wells, and the data and analyses of the water from wells. There are standard practices used by the CaWSC at Fort Irwin (and throughout their entire system of wells) for the drilling of boreholes that include the collection and processing of core and cuttings samples and geophysical log data. There are also standard procedures for the postprocessing of these samples and data.

\section{Sample Collection and Processing}

The well construction diagram and lithologic shaker and sieve logs document many of the drilling conditions and descriptions of samples collected during drilling of each borehole (Kojs and others, 2014). A rig lithology log is compiled at the rig site by geologists, and although this log is not published, it forms the basis for the final lithologic descriptions from microscopic examination of cuttings that are published as lithologic shaker and sieve logs.

Geologists collect samples of cuttings from the shaker table at drilled intervals of 10 feet (ft) using a number 20 mesh sieve (0.841 millimeters [mm], U.S.A. Standard Testing Sieve). These samples, which are referred to as shaker samples, are stored in multi-compartment containers, where each container is about $40 \times 50 \times 55 \mathrm{~mm}$, and larger samples are stored in plastic bags and archived. Descriptions of cuttings in the lithologic shaker log, which are based on the nomenclature for sediment size and roundness from Folk $(1954,1974)$, includes sediment (fragment) size and abundance of clay, sand, and gravel. For example, an interval might be described as "slightly gravelly sandy clay.” In some logs, compositions of rocks such as basalt or gneiss are also noted where these rock types form most of the cuttings; however, the cuttings are still described using the same sedimentary terminology. Typically, other rock properties (such as mineralogy, fabric, precise rock identification, foliation, and cementation) are not in the descriptions. Geologists can also collect shaker samples and make observations every few feet during drilling; therefore, minor variations in the cuttings are identified, and these variations can be interpreted as thin features such as individual, compositionally distinct beds, or sets of beds (or bedsets). For example, specific “clay or ash” beds a few feet thick are documented at two depths in borehole GOLD1.

Geologists also collect "sieve" samples from the shaker table. These samples are collected with a number 120 mesh sieve $(0.125 \mathrm{~mm}$, U.S.A. Standard Testing Sieve) and consist of volumetrically small samples collected every few feet that are combined to form a composite sample representing 20 - $\mathrm{ft}$ intervals. Sieve samples are stored in the same type of containers as the shaker samples.

In most boreholes, 2-4 intervals of core (typically 3-5 ft long) are collected, and the top and bottom of the core tube is photographed to show the core. Some cores sample part of a single sedimentary bed, and some cores sample two or more beds. The core is briefly described in the drilling logs and rig lithology.

The field-based, rig lithology log also documents "rig chatter"; the vibration of the rig associated with drilling through hard, resistant rock that has variations in material strength (such as large conglomerate clasts or during the transition from weak to strong rock). Rig chatter is a qualitative observation that highlights intervals where the rig is working hard to drill through material with large variations in material strength. These intervals are contrasted with 
intervals where there is no rig chatter, which is inferred to be material that is homogeneous in terms of material strength (either all strong or weak).

One of the challenges during drilling, and the use of drill hole data, is knowing the depth and depth interval from which the core or cuttings were derived. For the samples at Fort Irwin, the best information is that samples are within a few feet of the stated depth, and depth interval is probably within a few feet of the bottom of the borehole. To get to these estimates, the drilling engineers know the number of drill pipes in the ground (usually 10 or $20 \mathrm{ft}$ long), the amount of "stick up" of the pipe (which provides values less than a pipe length), and this provides the depth. For core, the length of cored rock is known (typically 3 or $5 \mathrm{ft}$ ), but the amount of recovered core (that which is in the core barrel) can vary from 0 to 100 percent. For core with 100 percent recovery, the depth of the entire core is known. However, if the recovery is less than 100 percent, the position of the piece of core within the cored interval is not known. For cuttings, the depth of the cutting head is known, but the delivery of the cuttings to the top of the borehole (ground surface) and shaker table depends on the circulation rate of the drilling mud. The drilling engineers measure the amount (rate) of drilling mud that is pumped into the hole, and periodically, the circulation rate is tested by adding a small amount of white rice into the drilling mud. Knowing the viscosity of the drilling mud, the rate of accent of the mud in the borehole, and the potential for size segregation of fragments during the accent, drilling engineers estimate that the cuttings collected every $10 \mathrm{ft}$ probably were derived from about a 2$\mathrm{ft}$-thick interval. Boreholes that deviate from being straight and vertical can affect the depth resolution, and boreholes at Fort Irwin typically do not have deviation logs collected, so the depth calculated from the drill pipes is used as the recorded depth.

A second challenge of using cuttings samples is the possibility that fragments were incorporated into the drilling mud at depths other than where they formed by the drill head (that is, they can be up-hole contamination during circulation of the mud). Up-hole contamination must always be considered when examining the cuttings. The conventional interpretation is that the drilling mud forms a mud cake along the borehole walls, and this insulates the wall rock from the drilling mud, thereby minimizing up-hole contamination. However, up-hole contamination is especially possible where borehole walls slough off, and these conditions can give rise to problems during drilling that include getting drilling pipes stuck and the loss of a hole. These types of drilling difficulties are typically recorded in the drilling logs, or have been informally communicated by the drilling engineer.

\section{Borehole Geophysical Log Data}

In each borehole in the Fort Irwin area, nine geophysical logs were collected: caliper, temperature, spontaneous potential, gamma-ray, four types of resistivity, and sonic velocity. Some of these logs are from sensors that are part of a single tool assemblage (or string), and some are from tool strings that have only one or two tools. All the logs are referenced to zero depth at the ground surface, there are no corrections (such as cable stretch) applied to the data, and it is assumed that there is no significant difference in possible cable stretch based on the different tool assemblages, so it is assumed that all tools for a given depth record data from the same rock in the wall of the borehole. For each tool string, the data from each sensor at different positions along the string are co-registered such that all data from that string are from the same depth. With the co-registration of data within a tool string, and the assumption that each tool records data from the same rock at a given depth, it is further assumed that data collected on successive runs (even days apart) also record data from the same rock at depth. In 
most boreholes, there were two stages of drilling; the initial smaller-diameter borehole, and the reamed larger-diameter borehole. Typically, geophysical log data were collected in the smalldiameter borehole; however, some reamed boreholes also have logs, and the importance is that many tools perform better in smaller diameter boreholes than larger diameter boreholes. All geophysical log data are collected with the tool moving up the borehole from the total depth, and the rate of accent determines the increments of data collection. All geophysical log data were collected at $0.1-\mathrm{ft}$ increments. The resistivity, spontaneous potential, and sonic velocity data are used at this resolution. The one exception is gamma-ray data (which is measured in counts per second) that has large variations in counts across short distances (that is, it is very "noisy”), and typically the data are smoothed with a 2-ft running average (fig. 1.1).

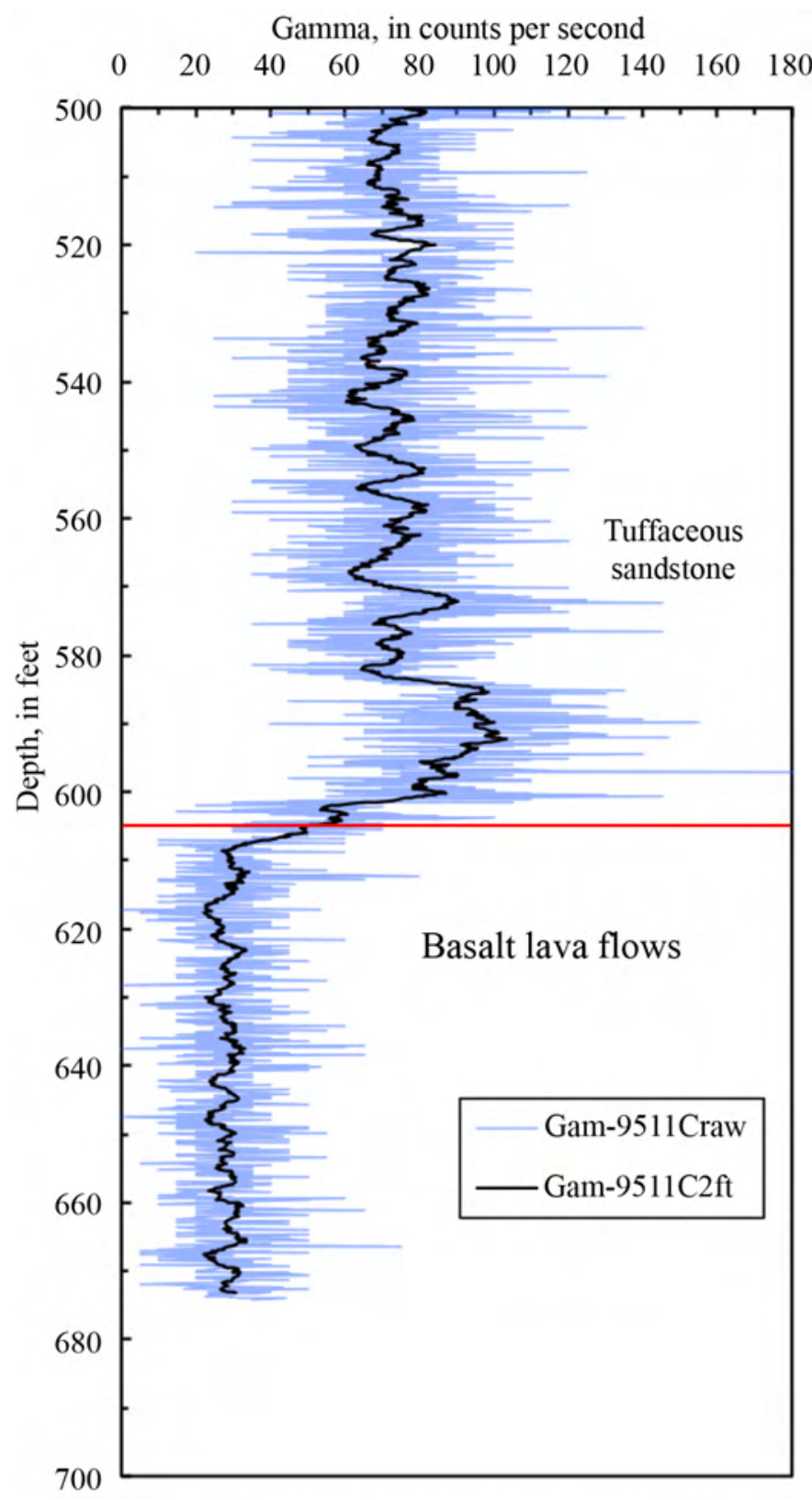

Figure 1.1. Graph of gamma-ray data in basalt flows and tuffaceous sedimentary rocks in borehole GOLD1 at Fort Irwin, California. Gam-9511C is log run; raw, raw data; 2ft, 2-foot running average. 
Caliper log data (CALIPER header in graphs) is the measure of the diameter of the borehole. Most boreholes in the study area have diameters of 8-12 inches, but some boreholes are about 16-18 inches. Typically, borehole walls have little variation in diameter, but some have small amounts of rugosity, or localized breakouts.

Spontaneous-potential data (SP header in graphs) records the natural potential developed between the borehole fluid (mud, surface water), formation water, and the surrounding rock material. Typically, spontaneous potential logs are used for determining bed thickness and separating nonporous from porous rocks in shale-sandstone and shale-carbonate sequences (Keys and MacCary, 1971). One challenge of using spontaneous potential logs in the Fort Irwin area is that most characterizations of spontaneous potential logs are from the petroleum industry where the rocks are sandstone, shale, and carbonate whereas at Fort Irwin there are numerous variations in volcaniclastic rocks that have not been specifically characterized. In the boreholes at Fort Irwin, the spontaneous potential data can have large ranges in values, the ranges differ from borehole to borehole, and some logs appear to be more responsive to the rocks in some boreholes and not others. These variations are described for individual boreholes.

Gamma-ray data (GAM header in graphs) records the amount of natural gamma radiation emitted by the rocks, and the main uses are for identification of lithology and stratigraphic correlations (Keys and MacCary, 1971). The most common radioisotopes in rocks are potassium-40 and daughter products of the uranium and thorium decay series (Keys and MacCary, 1971). In the petroleum industry, gamma-ray data are typically used for identification of clay-bearing sediments that have higher natural gamma activity than quartz sands and carbonates; however, these three rock types are not common in the Fort Irwin areas. At Fort Irwin, and adjacent Eagle Crags volcanic field, volcanic rocks range in composition from basalt (which has low amounts of potassium, uranium, and thorium) to rhyolite (which has high amounts of potassium, uranium, and thorium) (Sabin, 1994). These rocks form lava flows, pyroclastic deposits, and epiclastic rocks derived from these volcanic rocks. In several boreholes in Fort Irwin, basalt lava flows are interstratified with pyroclastic deposits or tuffaceous sandstone, and there are very low gamma values in the basalts and much higher values in the pyroclastic deposits or tuffaceous sandstone. Borehole GOLD1 has basalt flows at the bottom of the borehole that are overlain by tuffaceous sandstone, and is a good example of how gamma-ray data varies based on the composition of the rocks (fig. 1.1). Although not documented nor proven in this report, it is possible that at least some of the variations in gamma-ray data in the volcaniclastic rocks result from different compositions of clasts, or differences in compositions of the clasts compared to the matrix, and both of these conditions could result in large amounts of small-scale variability in gamma-ray data.

Resistivity logs in boreholes record the electrical resistivity of the rocks, and resistivity is influenced by the grain size (matrix) porosity, fracture porosity, continuity or permeability of the pore space, how much water is in the pore space, dissolved solids, and water quality (Keys and MacCary, 1971). For all resistivity logs, in beds that are thicker than the electrode spacing, the data can form simple curves that define the bed; however, as bed thickness becomes smaller than the electrode spacing, there can be two or more apparent smaller curves in or adjacent to the bed. The four types of resistivity logs used at Fort Irwin include short normal logs (RES(16N) header in graphs), long normal logs (RES(64N) header in graphs), lateral logs (LATERAL header in graphs), and single-point log (RES header in graphs). The short and long normal logs refer to the positions between electrodes (16 inches and 64 inches, respectively), 
and they measure the resistivity (1) along the borehole between the respective electrodes, and (2) penetration into the rocks with the short normal log having only a short penetration and the long normal log penetrating about 128 inches (Keys and MacCary, 1971). These configurations mean that the short normal data give good vertical details, and the long normal data give a better average or bulk resistivity. Lateral logs use widely spaced electrodes to penetrate deeply into the rock, and work best where the bed thickness exceeds twice the electrode spacing (Keys and MacCary, 1971). The single-point log measures the resistance in a small volume; therefore, the data are highly influenced by the resistivity of the drilling fluid (mud) in the borehole, and compared to other resistivity logs there are smaller amounts of influence along the borehole and penetration into the wall rock. These conditions can produce good, small-scale, high-resolution of variations in the wall rock (such as different beds).

Sonic velocity logs measure the velocity of an acoustic wave in the borehole through fluid in the pores of the rock and through the solid part of the rock (Keys and MacCary, 1971). Solid and hard rocks such as plutonic rocks (or lava flows) have high velocities, and slightly consolidated sedimentary rocks such as sandstone have low velocities (Keys and MacCary, 1971), so the velocity is a proxy for the strength of a rock. In the Fort Irwin boreholes, velocity data are typically plotted as "delta t" (DELTAT in microseconds per foot), and this is the inverse of the velocity of the rock, so hard rocks have low delta t values. Sonic logs are designed to be used in the saturated zone (Keys and MacCary, 1971); however, at Fort Irwin, sonic logs were run in the unsaturated zone and the DELTAT values typically have less sensitivity in the unsaturated zone compared to the saturated zone.

\section{Depth Resolution of Cuttings and Core Versus Geophysical Log Data}

Based on discussions with the drilling engineers and all the conditions and processes during drilling, the depth resolution of cuttings and core samples is probably within a few feet of the stated depth. In core, the amount of drilled rock is known, but where a contact in the core is located within the drilled interval varies depending on the amount of recovered core. The amount of rock drilled to form the cuttings sample probably came from the lower 2 feet of the drill run. Drilled depths have less uncertainty in the shallower part of the borehole, and the uncertainty increases with depth. With the sampling methods used, core samples are from the stated depth, with variation based on recovery, and cuttings samples provide about 2-ft-thick samples every $10 \mathrm{ft}$ down the borehole.

Geophysical log data are collected every $0.1 \mathrm{ft}$ along the borehole, and each type of log has a different length along the borehole that is sampled. The ability to resolve a contact also differs between logs; however, the depth of a detected contact is probably within a few feet of the actual contact. Borehole geophysical log data are measured with the length of cable in the borehole, but this can be influenced by deviated boreholes.

Comparison of depth and sampling techniques for cuttings, core, and geophysical logs suggests that the depths for the three methods are all about the same (probably within 1-2 ft); however, core and cuttings provide short intervals of sample whereas geophysical log data provide continuous and higher resolution data. The lithostratigraphic contacts presented in this report result from the combination of core, cuttings, and geophysical log data; thus, contacts are reported to the nearest $1 \mathrm{ft}$ and are not limited to the 10 - $\mathrm{ft}$ increments of the cuttings. 


\section{Time-domain Resistivity Geophysical Data}

Time-domain electromagnetic (TEM) data are collected at the ground surface using an induced electrical and magnetic field that can be used to derive a one-dimensional (1D) resistivity model, and Burgess and Bedrosian (2014) used this method at Fort Irwin to create "virtual boreholes" to depths as great as 1,650 ft. Rocks with very high resistivity include unweathered crystalline rocks, rocks with very low resistivity include sedimentary rocks with clay, and in unconsolidated sediments, coarse-grained deposits such as alluvial sand and gravel or sandstone have higher resistivity whereas finer grained rocks have lower resistivity (Burgess and Bedrosian, 2014). Data are typically collected at a variety of frequencies, and the different responses are used to calculate different resistivity properties with depth of penetration below the ground surface. The 1D models can be created using different techniques, and Burgess and Bedrosian (2014) used a minimum-layer model where the model calculated the best-fit minimum number of layers (typically 3-5 layers), and a fixed-thickness 20-layer model where model depth increments are set, typically with more closely spaced increments near the ground surface and the largest increments at greater depths.

Burgess and Bedrosian (2014) collected 79 TEM soundings throughout the Fort Irwin area, and many were located near boreholes. There were exceptions, but in their analysis, where the boreholes and TEM soundings were less than 3 kilometers $(\mathrm{km})$ apart, the borehole 64-inch, long-normal resistivity (RES64N) values compared well with the TEM model values. In many of the TEM soundings, resistivity is high near the land surface, but there are one or two (more or less) resistive layers from the near surface to depths of about $328 \mathrm{ft}$ that overlie a thick, lower resistivity layer. In some models, there is a thin, lower resistivity layer in the upper 10-80 ft below the land surface that is interpreted as variations in unsaturated zone moisture that are influenced by lithostratigraphic properties and matrix potential forces. Examples of this lower resistivity layer in the TEM fixed-layer models near NELT-series boreholes include NL7 ( NELT1), NL8, NL13 ( NELT4), NL14, NL17, NL18 ( NELT7), NL20 ( NELT3), NL25 ( NELT5), NL26, NL29, and NL30 ( NELT6). TEM fixed-layer models with low resistivity at surface and increasing with depth (to about $100 \mathrm{ft}$ ) include NL3 ( NELT1), NL9, NL10 ( NELT7), NL11 ( NELT3), NL18 ( NELT7), and NL19. 


\section{Appendix 2. Componentry data of cuttings samples in eight boreholes at}

Fort Irwin.

An Excel file of table 2.1 is also available for download at https://doi.org/10.3133/ofr20131024D. 
Table 2.1. Table of cuttings properties in GOLD1 and NELT-series boreholes in the GOLD1 and NELTseries boreholes at Fort Irwin, California.

[Samples have bulk sample estimates that are informed by descriptions of individual grains. Descriptions of abbreviations in first two columns. Footnotes indicate caveats to categories in specific samples and are indicated by highlighted cells.]

\begin{tabular}{|c|c|c|c|c|c|}
\hline Borehole & Borehole & GOLD1 & GOLD1 & GOLD1 & GOLD1 \\
\hline Depth & Sample depth & 40 & 60 & 70 & 80 \\
\hline Described & General description of grains & 0 & 77 & 0 & 20 \\
\hline Detailed & Detailed descriptions of grains & 0 & 28 & 0 & 14 \\
\hline Lithology & Lithology & & & & \\
\hline $\mathrm{p}-\mathrm{T}$ & pre-Tertiary & 0 & 0 & 0 & 0 \\
\hline OBas (1) & Olivine basalt (1) & 10 & 0 & 1 & 0 \\
\hline And-Rho & Andesite-Rhyolite & 60 & 97 & 95 & 60 \\
\hline Sed-T & Tuffaceous material & 5 & 3 & 2 & 40 \\
\hline Sed-L & Lithic sediment & 25 & 0 & 2 & 0 \\
\hline Surface shape & Surface shape & & & & \\
\hline Broken & Broken (clasts, rock) by drilling & 60 & 43 & 45 & 40 \\
\hline Original & Original clast shape & 40 & 57 & 55 & 60 \\
\hline Rims \& rinds & Rims and rinds & & & & \\
\hline Rim & Rims & 0 & 4 & 5 & 1 \\
\hline Rind & Rinds (calcite-silica) & 5 & 3 & 2 & 1 \\
\hline Coatings & Coatings & & & & \\
\hline Coat-T & Coating - tuffaceous & 0 & 1 & 0 & 30 \\
\hline Coat-Tb (2) & Coating - lithic-bearing ts (2) & 0 & 0 & 0 & 0 \\
\hline Coat-Tr (3) & Coating - lithic-rich ts (3) & & & & \\
\hline Coat-Lb (4) & Coating - pumice-bearing ss (4) & 0 & 0 & 0 & 0 \\
\hline Coat-L & Coating - (lithic) sandstone & 25 & 22 & 10 & 0 \\
\hline Norm coating & Normalized coatings & & & & \\
\hline Borehole & Borehole & GOLD1 & GOLD1 & GOLD1 & GOLD1 \\
\hline Depth & Sample depth & 40 & 60 & 70 & 80 \\
\hline Coat-T & Coating - tuffaceous & 0.0 & 2.8 & 0.0 & 100.0 \\
\hline Coat-Tb (2) & Coating - lithic-bearing ts (2) & 0.0 & 0.0 & 0.0 & 0.0 \\
\hline Coat-Tr (3) & Coating - lithic-rich ts (3) & & & & \\
\hline Coat-Lb (4) & Coating - pumice-bearing ss (4) & 0.0 & 0.0 & 0.0 & 0.0 \\
\hline Coat-L & Coating - (lithic) sandstone & 100.0 & 97.2 & 100.0 & 0.0 \\
\hline
\end{tabular}

\section{Footnotes}

(1) ABa, BAn

(2) Crys-bear

(3) Trans tsm

(4) PLr-Pb ss

\section{Footnotes (caveats and highlights):}

(1) Andesitic basalt (ABa) or basaltic andesite (BAn)

(2) Crystal-bearing

(3) Transitional to tuffaceous sandstone matrix

(4) Pumice-lithic-rich grades into pumice-bearing sandstone 
Table 2.1-Continued

\begin{tabular}{|c|c|c|c|c|c|c|c|c|c|}
\hline Borehole & GOLD1 & GOLD1 & GOLD1 & GOLD1 & GOLD1 & GOLD1 & GOLD1 & GOLD1 & GOLD1 \\
\hline Depth & 90 & 110 & 120 & 130 & 150 & 190 & 290 & 320 & 360 \\
\hline Described & 20 & 20 & 26 & 0 & 0 & 0 & 0 & 0 & 0 \\
\hline Detailed & 20 & 20 & 20 & 0 & 0 & 0 & 0 & 0 & 0 \\
\hline \multicolumn{10}{|l|}{ Lithology } \\
\hline $\mathrm{p}-\mathrm{T}$ & 0 & 0 & 0 & 0 & 0 & 0 & 0 & 0 & 0 \\
\hline OBas (1) & 0 & 0 & 0 & 0 & 0 & 0 & 0 & 0 & 0 \\
\hline And-Rho & 40 & 75 & 75 & 55 & 80 & 45 & 60 & 99.9 & 99.9 \\
\hline Sed-T & 59 & 25 & 25 & 40 & 20 & 45 & 35 & 0.1 & 0.1 \\
\hline Sed-L & 1 & 0 & 0 & 5 & 0 & 10 & 5 & 0 & 0 \\
\hline \multicolumn{10}{|l|}{ Surface shape } \\
\hline Broken & 60 & 35 & 30 & 40 & 25 & 30 & 70 & 98 & 94 \\
\hline Original & 40 & 65 & 70 & 60 & 75 & 70 & 30 & 2 & 6 \\
\hline \multicolumn{10}{|l|}{ Rims \& rinds } \\
\hline Rim & 2 & 1 & 1 & 5 & 2 & 0 & 5 & 1 & 5 \\
\hline Rind & 0 & 0 & 0 & 5 & 1 & 2 & 0 & 0 & 0 \\
\hline \multicolumn{10}{|l|}{ Coatings } \\
\hline Coat-T & 30 & 60 & 25 & 30 & 30 & 40 & 25 & 1 & 1 \\
\hline Coat-Tb (2) & 0 & 0 & 0 & 0 & 0 & 0 & 0 & 0 & 0 \\
\hline \multicolumn{10}{|l|}{ Coat-Tr (3) } \\
\hline Coat-Lb (4) & 0 & 0 & 0 & 0 & 0 & 0 & 0 & 0 & 0 \\
\hline Coat-L & 2 & 0 & 0 & 5 & 10 & 0 & 0 & 0 & 0 \\
\hline \multicolumn{10}{|l|}{ Norm coating } \\
\hline Borehole & GOLD1 & GOLD1 & GOLD1 & GOLD1 & GOLD1 & GOLD1 & GOLD1 & GOLD1 & GOLD1 \\
\hline Depth & 90 & 110 & 120 & 130 & 150 & 190 & 290 & 320 & 360 \\
\hline Coat-T & 93.8 & 100.0 & 100.0 & 85.7 & 75.0 & 100.0 & 100.0 & 100.0 & 100.0 \\
\hline Coat-Tb (2) & 0.0 & 0.0 & 0.0 & 0.0 & 0.0 & 0.0 & 0.0 & 0.0 & 0.0 \\
\hline Coat-Tr (3) & & & & & & & & & \\
\hline Coat-Lb (4) & 0.0 & 0.0 & 0.0 & 0.0 & 0.0 & 0.0 & 0.0 & 0.0 & 0.0 \\
\hline Coat-L & 6.3 & 0.0 & 0.0 & 14.3 & 25.0 & 0.0 & 0.0 & 0.0 & 0.0 \\
\hline
\end{tabular}

\section{Footnotes}
(1) ABa, BAn
(2) Crys-bear
(3) Trans tsm
(4) PLr-Pb ss 
Table 2.1-Continued

\begin{tabular}{|c|c|c|c|c|c|c|c|c|c|}
\hline Borehole & GOLD1 & GOLD1 & GOLD1 & GOLD1 & GOLD1 & GOLD1 & GOLD1 & NELT1 & NELT1 \\
\hline Depth & 410 & 430 & 540 & 580 & 620 & 640 & 680 & 50 & 70 \\
\hline Described & 0 & 0 & 0 & 0 & 0 & 0 & 0 & 17 & 9 \\
\hline Detailed & 0 & 0 & 0 & 0 & 0 & 0 & 0 & 17 & 9 \\
\hline \multicolumn{10}{|l|}{ Lithology } \\
\hline $\mathrm{p}-\mathrm{T}$ & 0 & 0 & 0 & 0 & 0 & 0 & 0 & 0 & 0 \\
\hline OBas (1) & 0 & 0 & 0 & 0 & 95 & 98 & 96 & 0 & 0 \\
\hline And-Rho & 95 & 85 & 35 & 30 & 3 & 1 & 2 & 95 & 95 \\
\hline Sed-T & 5 & 5 & 65 & 20 & 2 & 1 & 2 & 0 & 1 \\
\hline Sed-L & 0 & 10 & 0 & 50 & 0 & 0 & 0 & 5 & 4 \\
\hline \multicolumn{10}{|l|}{ Surface shape } \\
\hline Broken & 85 & 85 & 85 & 85 & 99 & 100 & 100 & 15 & 15 \\
\hline Original & 15 & 15 & 15 & 15 & 1 & 0 & 0 & 85 & 85 \\
\hline \multicolumn{10}{|l|}{ Rims \& rinds } \\
\hline Rim & 2 & 4 & 3 & 0 & 5 & 5 & 5 & 0 & 0 \\
\hline Rind & 0 & 1 & 0 & 0 & 0 & 0 & 0 & 2 & 2 \\
\hline \multicolumn{10}{|l|}{ Coatings } \\
\hline Coat-T & 2 & 0 & 15 & 10 & 0 & 0 & 0 & 1 & 1 \\
\hline Coat-Tb (2) & 0 & 0 & 0 & 0 & 0 & 0 & 0 & 0 & 0 \\
\hline \multicolumn{10}{|l|}{ Coat-Tr (3) } \\
\hline Coat-Lb (4) & 0 & 0 & 0 & 0 & 0 & 0 & 0 & 4 & 4 \\
\hline Coat-L & 0 & 2 & 0 & 15 & 0 & 0 & 0 & 3 & 5 \\
\hline \multicolumn{10}{|l|}{ Norm coating } \\
\hline Borehole & GOLD1 & GOLD1 & GOLD1 & GOLD1 & GOLD1 & GOLD1 & GOLD1 & NELT1 & NELT1 \\
\hline Depth & 410 & 430 & 540 & 580 & 620 & 640 & 680 & 50 & 70 \\
\hline Coat-T & 100.0 & 0.0 & 100.0 & 40.0 & 0.0 & 0.0 & 0.0 & 12.5 & 10.0 \\
\hline Coat-Tb (2) & 0.0 & 0.0 & 0.0 & 0.0 & 0.0 & 0.0 & 0.0 & 0.0 & 0.0 \\
\hline \multicolumn{10}{|l|}{ Coat-Tr (3) } \\
\hline Coat-Lb (4) & 0.0 & 0.0 & 0.0 & 0.0 & 0.0 & 0.0 & 0.0 & 50.0 & 40.0 \\
\hline Coat-L & 0.0 & 100.0 & 0.0 & 60.0 & 0.0 & 0.0 & 0.0 & 37.5 & 50.0 \\
\hline
\end{tabular}

\section{Footnotes}
(1) ABa, BAn
(2) Crys-bear
(3) Trans tsm
(4) PLr-Pb ss 
Table 2.1-Continued

\begin{tabular}{|c|c|c|c|c|c|c|c|c|c|}
\hline Borehole & NELT1 & NELT1 & NELT1 & NELT1 & NELT1 & NELT1 & NELT1 & NELT1 & NELT2 \\
\hline Depth & 80 & 100 & 120 & 170 & 180 & 240 & 430 & 440 & 60 \\
\hline Described & 25 & 12 & 12 & 0 & 0 & 0 & 8 & 0 & 17 \\
\hline Detailed & 24 & 12 & 12 & 0 & 0 & 0 & 8 & 0 & 17 \\
\hline \multicolumn{10}{|l|}{ Lithology } \\
\hline $\mathrm{p}-\mathrm{T}$ & 0 & 0 & 1 & 0 & 0 & 0 & 0 & 1 & 0 \\
\hline OBas (1) & 0 & 0 & 0 & 0 & 0 & 2 & 0 & 0 & 0 \\
\hline And-Rho & 90 & 99 & 99 & 100 & 100 & 98 & 100 & 99 & 100 \\
\hline Sed-T & 8 & 1 & 0 & 0 & 0 & 0 & 0 & 0 & 0 \\
\hline Sed-L & 2 & 0 & 0 & 0 & 0 & 0 & 0 & 0 & 0 \\
\hline \multicolumn{10}{|l|}{ Surface shape } \\
\hline Broken & 10 & 35 & 40 & 45 & 40 & 25 & 50 & 40 & 10 \\
\hline Original & 90 & 65 & 60 & 55 & 60 & 75 & 50 & 60 & 90 \\
\hline \multicolumn{10}{|l|}{ Rims \& rinds } \\
\hline Rim & 0 & 0 & 0 & 0 & 0 & 0 & 0 & 0 & 0 \\
\hline Rind & 0 & 0 & 0 & 0 & 0 & 0 & 0 & 0 & 0 \\
\hline \multicolumn{10}{|l|}{ Coatings } \\
\hline Coat-T & 2 & 4 & 5 & 2 & 4 & 3 & 5 & 2 & 0 \\
\hline Coat-Tb (2) & 5 & 0 & 1 & 0 & 0 & 0 & 0 & 0 & 1 \\
\hline \multicolumn{10}{|l|}{ Coat-Tr (3) } \\
\hline Coat-Lb (4) & 0 & 0 & 0 & 0 & 0 & 0 & 0 & 0 & 5 \\
\hline Coat-L & 0 & 0 & 1 & 0 & 0 & 0 & 1 & 0 & 0 \\
\hline \multicolumn{10}{|l|}{ Norm coating } \\
\hline Borehole & NELT1 & NELT1 & NELT1 & NELT1 & NELT1 & NELT1 & NELT1 & NELT1 & NELT2 \\
\hline Depth & 80 & 100 & 120 & 170 & 180 & 240 & 430 & 440 & 60 \\
\hline Coat-T & 28.6 & 100.0 & 71.4 & 100.0 & 100.0 & 100.0 & 83.3 & 100.0 & 0.0 \\
\hline Coat-Tb (2) & 71.4 & 0.0 & 14.3 & 0.0 & 0.0 & 0.0 & 0.0 & 0.0 & 16.7 \\
\hline Coat-Tr (3) & & & & & & & & & \\
\hline Coat-Lb (4) & 0.0 & 0.0 & 0.0 & 0.0 & 0.0 & 0.0 & 0.0 & 0.0 & 83.3 \\
\hline Coat-L & 0.0 & 0.0 & 14.3 & 0.0 & 0.0 & 0.0 & 16.7 & 0.0 & 0.0 \\
\hline
\end{tabular}

\section{Footnotes}
(1) ABa, BAn
(2) Crys-bear
(3) Trans tsm
(4) PLr-Pb ss 
Table 2.1-Continued

\begin{tabular}{|c|c|c|c|c|c|c|c|c|c|}
\hline Borehole & NELT2 & NELT2 & NELT2 & NELT2 & NELT2 & NELT2 & NELT3 & NELT3 & NELT3 \\
\hline Depth & 120 & 160 & 180 & 240 & 300 & 344 & 40 & 80 & 90 \\
\hline Described & 18 & 13 & 21 & 20 & 20 & 0 & 26 & 21 & 20 \\
\hline Detailed & 18 & 13 & 21 & 20 & 20 & 0 & 26 & 21 & 7 \\
\hline \multicolumn{10}{|l|}{ Lithology } \\
\hline $\mathrm{p}-\mathrm{T}$ & 0 & 0 & 0 & 0 & 0 & 0 & 0 & 1 & 0 \\
\hline OBas (1) & 0 & 0 & 0 & 0 & 0 & 0 & 0 & 0 & 0 \\
\hline And-Rho & 99 & 99 & 94 & 96 & 85 & 5 & 92 & 97 & 100 \\
\hline Sed-T & 0 & 1 & 3 & 3 & 8 & 35 & 8 & 2 & 0 \\
\hline Sed-L & 1 & 0 & 3 & 1 & 7 & 60 & 0 & 0 & 0 \\
\hline \multicolumn{10}{|l|}{ Surface shape } \\
\hline Broken & 15 & 15 & 3 & 10 & 5 & 2 & 15 & 20 & 5 \\
\hline Original & 85 & 85 & 97 & 90 & 95 & 98 & 85 & 80 & 95 \\
\hline \multicolumn{10}{|l|}{ Rims \& rinds } \\
\hline Rim & 0 & 0 & 0 & 0 & 0 & 0 & 0 & 2 & 0 \\
\hline Rind & 0 & 0 & 0 & 0 & 0 & 0 & 0 & 0 & 0 \\
\hline \multicolumn{10}{|l|}{ Coatings } \\
\hline Coat-T & 7 & 3 & 6 & 4 & 4 & 1 & 1 & 0 & 1 \\
\hline Coat-Tb (2) & 3 & 3 & 1 & 0 & 1 & 0 & 0 & 0 & 15 \\
\hline \multicolumn{10}{|l|}{ Coat-Tr (3) } \\
\hline Coat-Lb (4) & 2 & 0 & 3 & 1 & 0 & 0 & 0 & 0 & 0 \\
\hline Coat-L & 0 & 0 & 0 & 0 & 0 & 0 & 25 & 20 & 7 \\
\hline \multicolumn{10}{|l|}{ Norm coating } \\
\hline Borehole & NELT2 & NELT2 & NELT2 & NELT2 & NELT2 & NELT2 & NELT3 & NELT3 & NELT3 \\
\hline Depth & 120 & 160 & 180 & 240 & 300 & 344 & 40 & 80 & 90 \\
\hline Coat-T & 58.3 & 50.0 & 60.0 & 80.0 & 80.0 & 100.0 & 3.8 & 0.0 & 4.3 \\
\hline Coat-Tb (2) & 25.0 & 50.0 & 10.0 & 0.0 & 20.0 & 0.0 & 0.0 & 0.0 & 65.2 \\
\hline \multicolumn{10}{|l|}{ Coat-Tr (3) } \\
\hline Coat-Lb (4) & 16.7 & 0.0 & 30.0 & 20.0 & 0.0 & 0.0 & 0.0 & 0.0 & 0.0 \\
\hline Coat-L & 0.0 & 0.0 & 0.0 & 0.0 & 0.0 & 0.0 & 96.2 & 100.0 & 30.4 \\
\hline
\end{tabular}

\section{Footnotes}
(1) ABa, BAn
(2) Crys-bear
(3) Trans tsm
(4) PLr-Pb ss 
Table 2.1-Continued

\begin{tabular}{|c|c|c|c|c|c|c|c|c|c|}
\hline Borehole & NELT3 & NELT3 & NELT3 & NELT3 & NELT3 & NELT3 & NELT3 & NELT3 & NELT3 \\
\hline Depth & 100 & 110 & 120 & 160 & 200 & 240 & 280 & 320 & 360 \\
\hline Described & 21 & 20 & 25 & 24 & 0 & 0 & 31 & 0 & 20 \\
\hline Detailed & 21 & 20 & 25 & 24 & 0 & 0 & 31 & 0 & 20 \\
\hline \multicolumn{10}{|l|}{ Lithology } \\
\hline $\mathrm{p}-\mathrm{T}$ & 0 & 0 & 0 & 0 & 0 & 0 & 0 & 0 & 0 \\
\hline OBas (1) & 0 & 0 & 0 & 0 & 0 & 0 & 0 & 0 & 0 \\
\hline And-Rho & 100 & 98 & 97 & 100 & 95 & 92 & 97 & 90 & 90 \\
\hline Sed-T & 0 & 0 & 3 & 0 & 5 & 8 & 3 & 8 & 10 \\
\hline Sed-L & 0 & 2 & 0 & 0 & 0 & 0 & 0 & 2 & 0 \\
\hline \multicolumn{10}{|l|}{ Surface shape } \\
\hline Broken & 20 & 20 & 40 & 15 & 25 & 25 & 40 & 35 & 40 \\
\hline Original & 80 & 80 & 60 & 85 & 75 & 75 & 60 & 65 & 60 \\
\hline \multicolumn{10}{|l|}{ Rims \& rinds } \\
\hline Rim & 0 & 0 & 2 & 1 & 0 & 0 & 4 & 0 & 0 \\
\hline Rind & 15 & 1 & 1 & 0 & 2 & 0 & 2 & 0 & 0 \\
\hline \multicolumn{10}{|l|}{ Coatings } \\
\hline Coat-T & 0 & 1 & 15 & 10 & 15 & 15 & 5 & 12 & 1 \\
\hline Coat-Tb (2) & 10 & 14 & 5 & 5 & 0 & 0 & 10 & 0 & 9 \\
\hline Coat-Tr (3) & 5 & & & & & & & & \\
\hline Coat-Lb (4) & 0 & 0 & 0 & 0 & 0 & 0 & 0 & 0 & 0 \\
\hline Coat-L & 0 & 1 & 1 & 0 & 0 & 0 & 0 & 3 & 0 \\
\hline \multicolumn{10}{|l|}{ Norm coating } \\
\hline Borehole & NELT3 & NELT3 & NELT3 & NELT3 & NELT3 & NELT3 & NELT3 & NELT3 & NELT3 \\
\hline Depth & 100 & 110 & 120 & 160 & 200 & 240 & 280 & 320 & 360 \\
\hline Coat-T & 0.0 & 6.3 & 71.4 & 66.7 & 100.0 & 100.0 & 33.3 & 80.0 & 10.0 \\
\hline Coat-Tb (2) & 66.7 & 87.5 & 23.8 & 33.3 & 0.0 & 0.0 & 66.7 & 0.0 & 90.0 \\
\hline Coat-Tr (3) & 33.3 & & & & & & & & \\
\hline Coat-Lb (4) & 0.0 & 0.0 & 0.0 & 0.0 & 0.0 & 0.0 & 0.0 & 0.0 & 0.0 \\
\hline Coat-L & 0.0 & 6.3 & 4.8 & 0.0 & 0.0 & 0.0 & 0.0 & 20.0 & 0.0 \\
\hline
\end{tabular}

\section{Footnotes}
(1) ABa, BAn
(2) Crys-bear
(3) Trans tsm
(4) PLr-Pb ss 
Table 2.1-Continued

\begin{tabular}{|c|c|c|c|c|c|c|c|c|c|}
\hline Borehole & NELT3 & NELT3 & NELT3 & NELT3 & NELT3 & NELT3 & NELT4 & NELT4 & NELT4 \\
\hline Depth & 400 & 440 & 560 & 640 & 720 & 800 & 60 & 70 & 80 \\
\hline Described & 24 & 18 & 16 & 0 & 22 & 9 & 17 & 20 & 1 \\
\hline Detailed & 24 & 18 & 16 & 0 & 22 & 9 & 0 & 0 & 1 \\
\hline \multicolumn{10}{|l|}{ Lithology } \\
\hline $\mathrm{p}-\mathrm{T}$ & 0 & 0 & 0 & 0 & 1 & 0 & 0 & 0 & 0 \\
\hline OBas (1) & 0 & 0 & 0 & 0 & 0 & 0 & 0 & 0 & 0 \\
\hline And-Rho & 99 & 99 & 99 & 98 & 95 & 95 & 14 & 97 & 85 \\
\hline Sed-T & 1 & 1 & 1 & 2 & 4 & 5 & 1 & 3 & 0 \\
\hline Sed-L & 0 & 0 & 0 & 0 & 0 & 0 & 85 & 0 & 15 \\
\hline \multicolumn{10}{|l|}{ Surface shape } \\
\hline Broken & 55 & 15 & 35 & 45 & 50 & 30 & 95 & 5 & 5 \\
\hline Original & 45 & 85 & 65 & 55 & 50 & 70 & 5 & 95 & 95 \\
\hline \multicolumn{10}{|l|}{ Rims \& rinds } \\
\hline Rim & 0 & 0 & 0 & 0 & 0 & 0 & 0 & 0 & 0 \\
\hline Rind & 0 & 0 & 0 & 0 & 0 & 0 & 2 & 0 & 0 \\
\hline \multicolumn{10}{|l|}{ Coatings } \\
\hline Coat-T & 1 & 8 & 5 & 7 & 1 & 8 & 2 & 14 & 6 \\
\hline Coat-Tb (2) & 7 & 2 & 0 & 0 & 3 & 0 & 1 & 1 & 2 \\
\hline \multicolumn{10}{|l|}{ Coat-Tr (3) } \\
\hline Coat-Lb (4) & 0 & 0 & 0 & 0 & 0 & 0 & 1 & 0 & 0 \\
\hline Coat-L & 0 & 0 & 0 & 0 & 1 & 0 & 1 & 0 & 0 \\
\hline \multicolumn{10}{|l|}{ Norm coating } \\
\hline Borehole & NELT3 & NELT3 & NELT3 & NELT3 & NELT3 & NELT3 & NELT4 & NELT4 & NELT4 \\
\hline Depth & 400 & 440 & 560 & 640 & 720 & 800 & 60 & 70 & 80 \\
\hline Coat-T & 12.5 & 80.0 & 100.0 & 100.0 & 20.0 & 100.0 & 40.0 & 93.3 & 75.0 \\
\hline Coat-Tb (2) & 87.5 & 20.0 & 0.0 & 0.0 & 60.0 & 0.0 & 20.0 & 6.7 & 25.0 \\
\hline Coat-Tr (3) & & & & & & & & & \\
\hline Coat-Lb (4) & 0.0 & 0.0 & 0.0 & 0.0 & 0.0 & 0.0 & 20.0 & 0.0 & 0.0 \\
\hline Coat-L & 0.0 & 0.0 & 0.0 & 0.0 & 20.0 & 0.0 & 20.0 & 0.0 & 0.0 \\
\hline
\end{tabular}

\section{Footnotes}
(1) ABa, BAn
(2) Crys-bear
(3) Trans tsm
(4) PLr-Pb ss 
Table 2.1-Continued

\begin{tabular}{|c|c|c|c|c|c|c|c|c|c|}
\hline Borehole & NELT4 & NELT4 & NELT4 & NELT4 & NELT4 & NELT4 & NELT4 & NELT4 & NELT5 \\
\hline Depth & 90 & 100 & 110 & 120 & 130 & 140 & 180 & 240 & 50 \\
\hline Described & 13 & 16 & 11 & 24 & 29 & 20 & 21 & 0 & 13 \\
\hline Detailed & 8 & 0 & 0 & 0 & 0 & 0 & 0 & 0 & 13 \\
\hline \multicolumn{10}{|l|}{ Lithology } \\
\hline $\mathrm{p}-\mathrm{T}$ & 0 & 0 & 0 & 0 & 0 & 0 & 0 & 0 & 0 \\
\hline OBas (1) & 0 & 0 & 0 & 0 & 0 & 0 & 0 & 0 & 0 \\
\hline And-Rho & 25 & 75 & 98 & 25 & 40 & 30 & 1 & 1 & 100 \\
\hline Sed-T & 0 & 5 & 0 & 75 & 30 & 20 & 99 & 0 & 0 \\
\hline Sed-L & 75 & 20 & 2 & 0 & 30 & 50 & 0 & 99 & 0 \\
\hline \multicolumn{10}{|l|}{ Surface shape } \\
\hline Broken & 80 & 50 & 0 & 5 & 0 & 0 & 10 & 95 & 10 \\
\hline Original & 20 & 50 & 100 & 95 & 100 & 100 & 90 & 5 & 60 \\
\hline \multicolumn{10}{|l|}{ Rims \& rinds } \\
\hline Rim & 0 & 0 & 0 & 0 & 0 & 0 & 0 & 0 & 0 \\
\hline Rind & 0 & 0 & 0 & 0 & 0 & 0 & 0 & 0 & 0 \\
\hline \multicolumn{10}{|l|}{ Coatings } \\
\hline Coat-T & 5 & 5 & 4 & 5 & 7 & 0 & 2 & 0 & 8 \\
\hline Coat-Tb (2) & 0 & 0 & 1 & 0 & 0 & 0 & 0 & 0 & 2 \\
\hline \multicolumn{10}{|l|}{ Coat-Tr (3) } \\
\hline Coat-Lb (4) & 0 & 0 & 0 & 0 & 0 & 0 & 0 & 0 & 15 \\
\hline Coat-L & 0 & 0 & 0 & 0 & 5 & 10 & 0 & 0 & 0 \\
\hline \multicolumn{10}{|l|}{ Norm coating } \\
\hline Borehole & NELT4 & NELT4 & NELT4 & NELT4 & NELT4 & NELT4 & NELT4 & NELT4 & NELT5 \\
\hline Depth & 90 & 100 & 110 & 120 & 130 & 140 & 180 & 240 & 50 \\
\hline Coat-T & 100.0 & 100.0 & 80.0 & 100.0 & 58.3 & 0.0 & 100.0 & 0.0 & 32.0 \\
\hline Coat-Tb (2) & 0.0 & 0.0 & 20.0 & 0.0 & 0.0 & 0.0 & 0.0 & 0.0 & 8.0 \\
\hline Coat-Tr (3) & & & & & & & & & \\
\hline Coat-Lb (4) & 0.0 & 0.0 & 0.0 & 0.0 & 0.0 & 0.0 & 0.0 & 0.0 & 60.0 \\
\hline Coat-L & 0.0 & 0.0 & 0.0 & 0.0 & 41.7 & 100.0 & 0.0 & 0.0 & 0.0 \\
\hline
\end{tabular}

\section{Footnotes}
(1) ABa, BAn
(2) Crys-bear
(3) Trans tsm
(4) PLr-Pb ss 
Table 2.1-Continued

\begin{tabular}{|c|c|c|c|c|c|c|c|c|c|}
\hline Borehole & NELT5 & NELT5 & NELT5 & NELT5 & NELT5 & NELT5 & NELT5 & NELT5 & NELT5 \\
\hline Depth & 60 & 90 & 100 & 120 & 130 & 150 & 170 & 180 & 240 \\
\hline Described & 23 & 16 & 14 & 17 & 0 & 30 & 0 & 18 & 13 \\
\hline Detailed & 23 & 16 & 0 & 17 & 0 & 14 & 0 & 0 & 0 \\
\hline \multicolumn{10}{|l|}{ Lithology } \\
\hline $\mathrm{p}-\mathrm{T}$ & 0 & 0 & 0 & 0 & 0 & 0 & 0 & 0 & 0 \\
\hline OBas (1) & 0 & 0 & 0 & 0 & 0 & 0 & 0 & 0 & 0 \\
\hline And-Rho & 100 & 100 & 100 & 100 & 100 & 100 & 99 & 100 & 100 \\
\hline Sed-T & 0 & 0 & 0 & 0 & 0 & 0 & 1 & 0 & 0 \\
\hline Sed-L & 0 & 0 & 0 & 0 & 0 & 0 & 0 & 0 & 0 \\
\hline \multicolumn{10}{|l|}{ Surface shape } \\
\hline Broken & 25 & 40 & 55 & 35 & 65 & 55 & 50 & 40 & 50 \\
\hline Original & 75 & 60 & 45 & 65 & 35 & 45 & 50 & 60 & 50 \\
\hline \multicolumn{10}{|l|}{ Rims \& rinds } \\
\hline Rim & 0 & 0 & 0 & 0 & 0 & 0 & 0 & 0 & 0 \\
\hline Rind & 0 & 0 & 0 & 0 & 2 & 0 & 0 & 1 & 0 \\
\hline \multicolumn{10}{|l|}{ Coatings } \\
\hline Coat-T & 8 & 8 & 6 & 7 & 6 & 5 & 3 & 2 & 3 \\
\hline Coat-Tb (2) & 2 & 0 & 0 & 3 & 1 & 0 & 1 & 7 & 3 \\
\hline \multicolumn{10}{|l|}{ Coat-Tr (3) } \\
\hline Coat-Lb (4) & 4 & 2 & 4 & 0 & 1 & 3 & 0 & 1 & 1 \\
\hline Coat-L & 1 & 1 & 0 & 0 & 0 & 0 & 0 & 0 & 0 \\
\hline \multicolumn{10}{|l|}{ Norm coating } \\
\hline Borehole & NELT5 & NELT5 & NELT5 & NELT5 & NELT5 & NELT5 & NELT5 & NELT5 & NELT5 \\
\hline Depth & 60 & 90 & 100 & 120 & 130 & 150 & 170 & 180 & 240 \\
\hline Coat-T & 53.3 & 72.7 & 60.0 & 70.0 & 75.0 & 62.5 & 75.0 & 20.0 & 42.9 \\
\hline Coat-Tb (2) & 13.3 & 0.0 & 0.0 & 30.0 & 12.5 & 0.0 & 25.0 & 70.0 & 42.9 \\
\hline \multicolumn{10}{|l|}{ Coat-Tr (3) } \\
\hline Coat-Lb (4) & 26.7 & 18.2 & 40.0 & 0.0 & 12.5 & 37.5 & 0.0 & 10.0 & 14.3 \\
\hline Coat-L & 6.7 & 9.1 & 0.0 & 0.0 & 0.0 & 0.0 & 0.0 & 0.0 & 0.0 \\
\hline
\end{tabular}

\section{Footnotes}
(1) ABa, BAn
(2) Crys-bear
(3) Trans tsm
(4) PLr-Pb ss 
Table 2.1-Continued

\begin{tabular}{|c|c|c|c|c|c|c|c|c|c|}
\hline Borehole & NELT5 & NELT5 & NELT5 & NELT5 & NELT6 & NELT6 & NELT6 & NELT6 & NELT6 \\
\hline Depth & 290 & 300 & 360 & 400 & 60 & 90 & 120 & 180 & 240 \\
\hline Described & 0 & 0 & 23 & 0 & 17 & 0 & 17 & 12 & 0 \\
\hline Detailed & 0 & 0 & 23 & 0 & 17 & 0 & 17 & 12 & 0 \\
\hline \multicolumn{10}{|l|}{ Lithology } \\
\hline $\mathrm{p}-\mathrm{T}$ & 0 & 0 & 0 & 0 & 1 & 0 & 0 & 0 & 0 \\
\hline OBas (1) & 0 & 0 & 0 & 0 & 0 & 0 & 1 & 0 & 1 \\
\hline And-Rho & 100 & 100 & 98 & 100 & 99 & 100 & 99 & 100 & 99 \\
\hline Sed-T & 0 & 0 & 1 & 0 & 0 & 0 & 0 & 0 & 0 \\
\hline Sed-L & 0 & 0 & 1 & 0 & 0 & 0 & 0 & 0 & 0 \\
\hline \multicolumn{10}{|l|}{ Surface shape } \\
\hline Broken & 70 & 60 & 35 & 65 & 60 & 30 & 60 & 75 & 60 \\
\hline Original & 30 & 40 & 65 & 35 & 40 & 70 & 40 & 25 & 40 \\
\hline \multicolumn{10}{|l|}{ Rims \& rinds } \\
\hline Rim & 0 & 0 & 1 & 0 & 0 & 0 & 0 & 0 & 0 \\
\hline Rind & 0 & 0 & 0 & 0 & 2 & 0 & 0 & 0 & 0 \\
\hline \multicolumn{10}{|l|}{ Coatings } \\
\hline Coat-T & 3 & 2 & 6 & 5 & 3 & 4 & 3 & 3 & 1 \\
\hline Coat-Tb (2) & 1 & 1 & 2 & 1 & 1 & 0 & 1 & 0 & 1 \\
\hline \multicolumn{10}{|l|}{ Coat-Tr (3) } \\
\hline Coat-Lb (4) & 0 & 0 & 0 & 0 & 0 & 0 & 0 & 0 & 0 \\
\hline Coat-L & 0 & 0 & 0 & 0 & 0 & 0 & 0 & 0 & 1 \\
\hline \multicolumn{10}{|l|}{ Norm coating } \\
\hline Borehole & NELT5 & NELT5 & NELT5 & NELT5 & NELT6 & NELT6 & NELT6 & NELT6 & NELT6 \\
\hline Depth & 290 & 300 & 360 & 400 & 60 & 90 & 120 & 180 & 240 \\
\hline Coat-T & 75.0 & 66.7 & 75.0 & 83.3 & 75.0 & 100.0 & 75.0 & 100.0 & 33.3 \\
\hline Coat-Tb (2) & 25.0 & 33.3 & 25.0 & 16.7 & 25.0 & 0.0 & 25.0 & 0.0 & 33.3 \\
\hline Coat-Tr (3) & & & & & & & & & \\
\hline Coat-Lb (4) & 0.0 & 0.0 & 0.0 & 0.0 & 0.0 & 0.0 & 0.0 & 0.0 & 0.0 \\
\hline Coat-L & 0.0 & 0.0 & 0.0 & 0.0 & 0.0 & 0.0 & 0.0 & 0.0 & 33.3 \\
\hline
\end{tabular}

\section{Footnotes}
(1) ABa, BAn
(2) Crys-bear
(3) Trans tsm
(4) PLr-Pb ss 
Table 2.1-Continued

\begin{tabular}{|c|c|c|c|c|c|c|c|c|c|}
\hline Borehole & NELT6 & NELT6 & NELT7 & NELT7 & NELT7 & NELT7 & NELT7 & NELT7 & NELT7 \\
\hline Depth & 360 & 400 & 50 & 60 & 70 & 80 & 100 & 120 & 140 \\
\hline Described & 0 & 8 & 19 & 18 & 13 & 24 & 23 & 28 & 2 \\
\hline Detailed & 0 & 8 & 0 & 18 & 0 & 4 & 21 & 28 & 0 \\
\hline \multicolumn{10}{|l|}{ Lithology } \\
\hline $\mathrm{p}-\mathrm{T}$ & 0 & 0 & 50 & 50 & 44 & 57 & 42 & 15 & 30 \\
\hline OBas (1) & 1 & 0 & 0 & 0 & 0 & 1 & 1 & 0 & 2 \\
\hline And-Rho & 98 & 100 & 40 & 45 & 40 & 40 & 55 & 83 & 67 \\
\hline Sed-T & 1 & 0 & 0 & 0 & 1 & 1 & 1 & 0 & 1 \\
\hline Sed-L & 0 & 0 & 10 & 5 & 15 & 1 & 1 & 2 & 1 \\
\hline \multicolumn{10}{|l|}{ Surface shape } \\
\hline Broken & 80 & 65 & 15 & 5 & 15 & 15 & 10 & 10 & 10 \\
\hline Original & 20 & 35 & 85 & 95 & 85 & 85 & 90 & 90 & 90 \\
\hline \multicolumn{10}{|l|}{ Rims \& rinds } \\
\hline Rim & 0 & 0 & 0 & 0 & 0 & 0 & 0 & 0 & 0 \\
\hline Rind & 0 & 0 & 2 & 1 & 1 & 0 & 1 & 0 & 0 \\
\hline \multicolumn{10}{|l|}{ Coatings } \\
\hline Coat-T & 2 & 2 & 1 & 1 & 1 & 1 & 4 & 9 & 4 \\
\hline Coat-Tb (2) & 0 & 0 & 0 & 0 & 0 & 5 & 7 & 1 & 1 \\
\hline \multicolumn{10}{|l|}{ Coat-Tr (3) } \\
\hline Coat-Lb (4) & 0 & 0 & 20 & 13 & 14 & 8 & 4 & 7 & 2 \\
\hline Coat-L & 0 & 0 & 1 & 1 & 0 & 1 & 0 & 3 & 3 \\
\hline \multicolumn{10}{|l|}{ Norm coating } \\
\hline Borehole & NELT6 & NELT6 & NELT7 & NELT7 & NELT7 & NELT7 & NELT7 & NELT7 & NELT7 \\
\hline Depth & 360 & 400 & 50 & 60 & 70 & 80 & 100 & 120 & 140 \\
\hline Coat-T & 100.0 & 100.0 & 4.5 & 6.7 & 6.7 & 6.7 & 26.7 & 45.0 & 40.0 \\
\hline Coat-Tb (2) & 0.0 & 0.0 & 0.0 & 0.0 & 0.0 & 33.3 & 46.7 & 5.0 & 10.0 \\
\hline Coat-Tr (3) & & & & & & & & & \\
\hline Coat-Lb (4) & 0.0 & 0.0 & 90.9 & 86.7 & 93.3 & 53.3 & 26.7 & 35.0 & 20.0 \\
\hline Coat-L & 0.0 & 0.0 & 4.5 & 6.7 & 0.0 & 6.7 & 0.0 & 15.0 & 30.0 \\
\hline
\end{tabular}

\section{Footnotes}
(1) ABa, BAn
(2) Crys-bear
(3) Trans tsm
(4) PLr-Pb ss 
Table 2.1-Continued

\begin{tabular}{|c|c|c|c|c|c|}
\hline Borehole & NELT7 & NELT7 & NELT7 & NELT7 & NELT7 \\
\hline Depth & 160 & 180 & 210 & 230 & 240 \\
\hline Described & 0 & 33 & 0 & 0 & 23 \\
\hline Detailed & 0 & 33 & 0 & 0 & 23 \\
\hline \multicolumn{6}{|l|}{ Lithology } \\
\hline $\mathrm{p}-\mathrm{T}$ & 54 & 35 & 67 & 82 & 78 \\
\hline OBas (1) & 1 & 0 & 0 & 0 & 0 \\
\hline And-Rho & 45 & 63 & 30 & 15 & 20 \\
\hline Sed-T & 0 & 2 & 3 & 2 & 2 \\
\hline Sed-L & 0 & 0 & 0 & 1 & 0 \\
\hline \multicolumn{6}{|l|}{ Surface shape } \\
\hline Broken & 5 & 10 & 5 & 10 & 15 \\
\hline Original & 95 & 90 & 95 & 90 & 85 \\
\hline \multicolumn{6}{|l|}{ Rims \& rinds } \\
\hline Rim & 0 & 0 & 0 & 0 & 0 \\
\hline Rind & 0 & 0 & 0 & 0 & 0 \\
\hline \multicolumn{6}{|l|}{ Coatings } \\
\hline Coat-T & 10 & 7 & 6 & 4 & 7 \\
\hline Coat-Tb (2) & 3 & 3 & 3 & 1 & 3 \\
\hline \multicolumn{6}{|l|}{ Coat-Tr (3) } \\
\hline Coat-Lb (4) & 2 & 3 & 0 & 0 & 0 \\
\hline Coat-L & 0 & 2 & 1 & 0 & 0 \\
\hline \multicolumn{6}{|l|}{ Norm coating } \\
\hline Borehole & NELT7 & NELT7 & NELT7 & NELT7 & NELT7 \\
\hline Depth & 160 & 180 & 210 & 230 & 240 \\
\hline Coat-T & 66.7 & 46.7 & 60.0 & 80.0 & 70.0 \\
\hline Coat-Tb (2) & 20.0 & 20.0 & 30.0 & 20.0 & 30.0 \\
\hline Coat-Tr (3) & & & & & \\
\hline Coat-Lb (4) & 13.3 & 20.0 & 0.0 & 0.0 & 0.0 \\
\hline Coat-L & 0.0 & 13.3 & 10.0 & 0.0 & 0.0 \\
\hline
\end{tabular}

\section{Footnotes}
(1) ABa, BAn
(2) Crys-bear
(3) Trans tsm
(4) PLr-Pb ss 
ISSN 2331-1258 (online)

https://doi.org/10.3133/

of $20131024 \mathrm{D}$ 